\title{
Ideología y subjetivación desde una intervención filosófica materialista
}

\section{Lectura sintomática y crítica}

Tesis para optar por el grado de Doctora en Filosofía

Doctoranda: Mg. Fabiana Parra

Director: Dr. Pedro Karczmarczyk (CONICET, UNLP)

Codirector: Dr. Oscar Esquisabel (CONICET, UNQ, UNLP)

28 de noviembre de 2019 


\section{ÍNDICE}

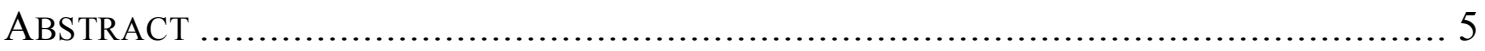

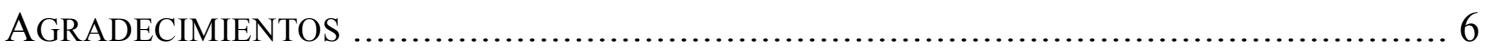

MÉTODO DE CiTAS Y ABREVIATURAS.......................................................... 7

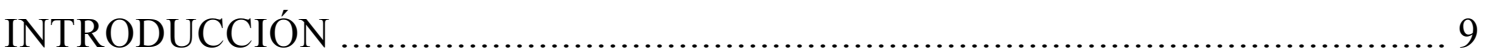

PARTE I. LA IDEOLOGÍA DESDE UNA PERSPECTIVA MATERIALISTA . . 20

CAPÍTUlo I. LeCTURA DE MARX POR AlTHUSSER .................................................21

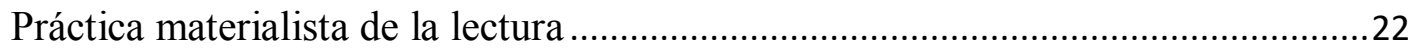

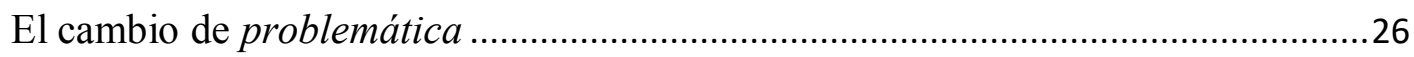

Ruptura epistemológica con la problemática ideológica ..........................................29

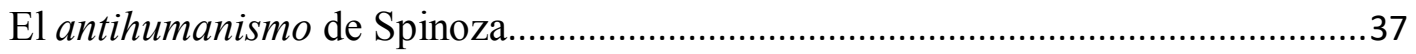

La ideología humanista y la crisis del marxismo ......................................................39

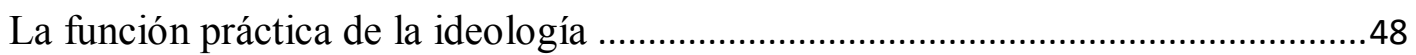

La crítica a la concepción empirista del conocimiento ...........................................52

CAPÍTULO II. EL CONOCIMIENTO DEL TODO COMPLEJO SOBREDETERMINADO ...............55

El modo de producción (materialista) de conocimiento ............................................56

Causalidad estructural y causalidad inmanente .......................................................67

La determinación en última instancia ....................................................................69

CAPÍtUlo III. LA FILOSOFÍA COMO LUCHA DE CLASES EN LA TEORÍA...........................78

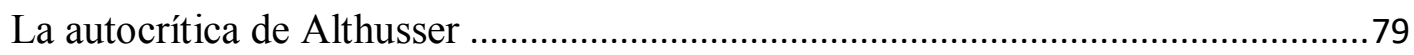

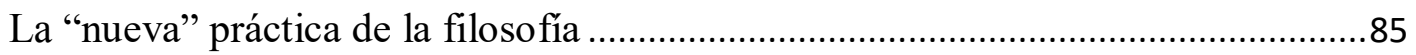

La filosofía en el "último" Althusser: el materialismo aleatorio ...............................91

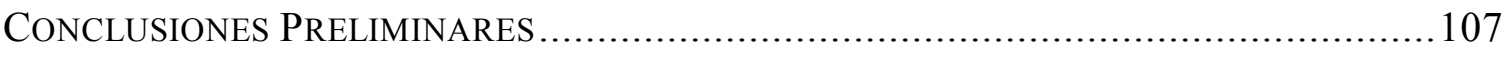

PARTE II. IDEOLOGÍA Y SUBJETIVACIÓN .......................................... 112

CAPÍTUlo IV. HACIA UNA TEORÍA MATERIALISTA DE LA IDEOLOGÍA ....................... 113

La reformulación de la ideología de Althusser .......................................................114

La reproducción de las relaciones de producción....................................................117

El "materialismo de lo imaginario" de Spinoza .......................................................122

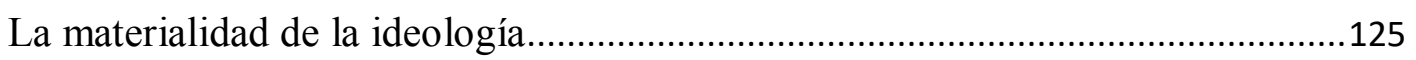

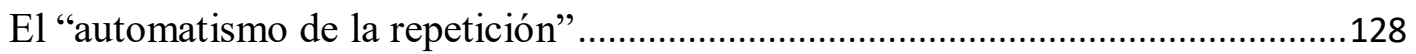

CAPÍTULO V. LA INTERPELACIÓN IDEOLÓGICA EN IDEOLOGÍA Y APARATOS..................134

El mecanismo de subjetivación/ sujeción ............................................................135

Reconocimiento ideológico y estructura de la ideología .........................................138

El desconocimiento y la ilusión de unidad/ totalidad.............................................142

¿Sujetos libres, sujetados o agentes? ................................................................. 147

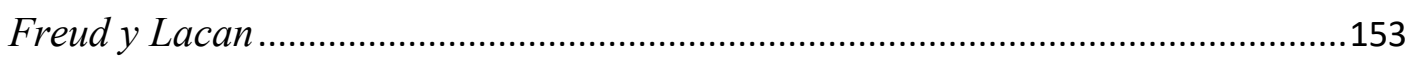

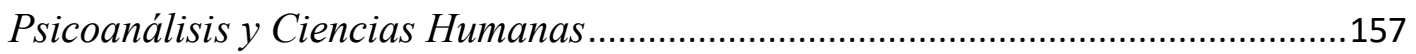

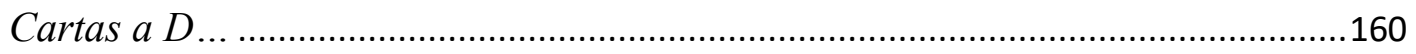

CAPÍTUlo VI. CRÍTICAS A LA INTERPELACIÓN IDEOLÓGICA ...................................... 164

Zizek y su lectura de los sujetos siempre ya interpelados ........................................165

Butler y su lectura de los sujetos siempre ya apasionados ....................................170

Pêcheux y su lectura de los sujetos siempre ya hablados .......................................175

La primacía de la lucha de clases en los AIE ...........................................................179 
Identificaciones, contraidentificaciones y desidentificaciones .............................181

La reproducción/ transformación de las relaciones de producción ...........................184

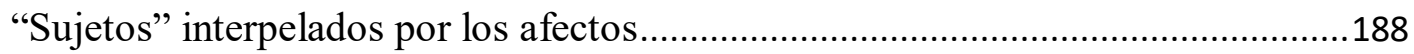

CAPÍTULO VII. LA INTERPELACIÓN COMO PERSUASIÓN DISCURSIVA .......................... 194

Las Tres notas sobre la teoría de los discursos ......................................................195

Sujetos persuadidos y reclutados por los discursos ..............................................204

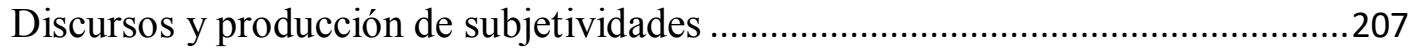

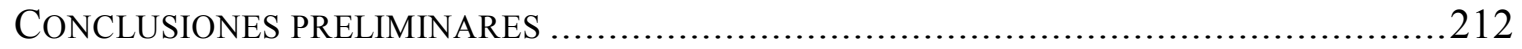

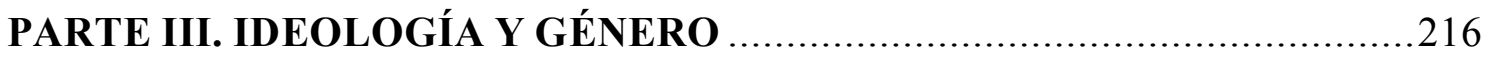

CAPÍtUlo VIII. AlthusSER DENTRO DE SUS LÍMITES .........................................217

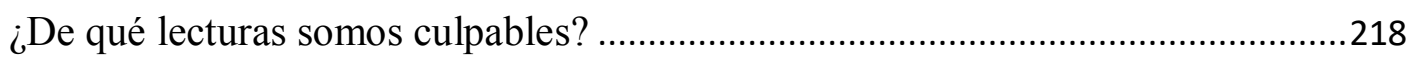

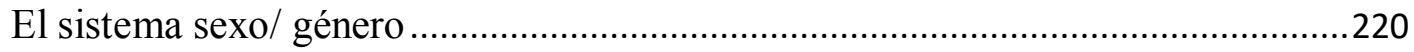

La reproducción desde perspectivas feministas críticas........................................222

Los efectos materiales de los discursos en la guerra contra las mujeres.................230

Ideología de la femineidad y persuasión discursiva .................................................234

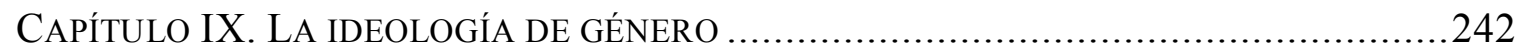

La ideología de género desde una perspectiva feminista .......................................243

Vicisitudes del concepto de ideología ................................................................248

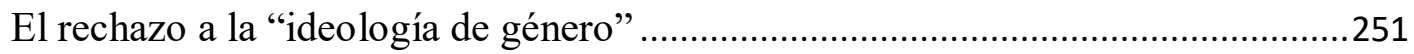

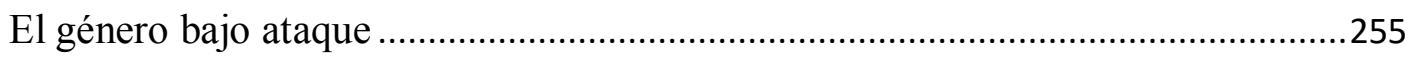

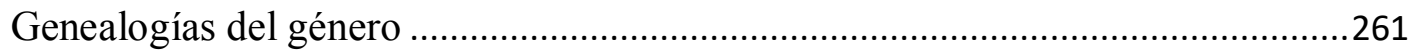

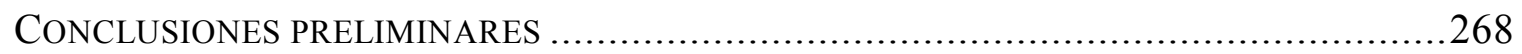

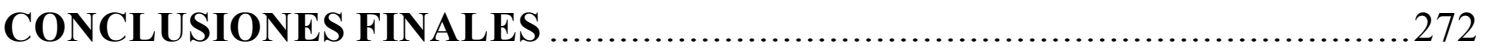

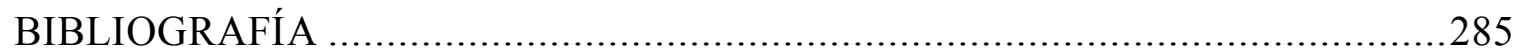




\section{Resumen}

El objetivo central de este trabajo es mostrar que la comprensión de la ideología desde su existencia material, propuesta por Althusser, a través de la práctica de la interpelación ideológica, permite dar cuenta de los procesos de subjetivación y sujeción. Sin embargo, existe en la propuesta de Althusser, un silencio teórico respecto al modo de producción de subjetividades generizadas.

Para ello, en primer lugar, proponemos mostrar en qué consiste la intervención materialista de Althusser, en la que se formulan conceptos centrales que examinaremos, como el de contradicción sobredeterminada, el de causalidad estructural, el de nueva práctica filosófica y el de lectura sintomática.

En segundo lugar, proponemos mostrar que la reformulación del concepto de ideología que propone Althusser constituye una demarcación con los tratamientos de tipo idealistas en los que la ideología es comprendida como simple error, y en los que se supone al "sujeto" como categoría central. Mostraremos que, en el nuevo marco, la ideología -con una naturaleza material e imaginaria- tiene por función central constituir individuos en sujetos mediante el complejo mecanismo de la interpelación ideológica. De manera que, la inscripción de la ideología en bases materialistas, implica también pasar a comprender al sujeto como una categoría derivada.

Finalmente, proponemos mostrar un límite en la propuesta de Althusser: el de no dar cuenta de los mecanismos específicos que operan en los procesos de constitución de las subjetividades generizadas. Mostraremos que, si hacemos una lectura sintomática sobre el propio silencio de Althusser podemos dar lugar a una nueva problemática, la de la articulación entre ideología y género; una problemática que en la actualidad cobra cada vez mayor importancia.

Palabras clave: ideología, subjetivación, lectura sintomática, crítica, género. 


\section{Abstract}

The main goal of this paper is to explore how the ideology reformulation of Luis Althusser shows the effectiveness of the ideology's materiality within the processes of subjectivation and subjection, through the ideological interpellation practice. However, there is a theoretical gap in Althusser's proposal regarding the gendered subjectivities production mode.

First, we aim to analyse the materialist intervention Althusser makes, for which the key concepts overdetermined contradiction, structural causality, new philosophical practice and symptomatic reading will be examined.

Secondly, we aim to show that Althusser's reformulation of the concept of ideology constitutes a deviation from the idealistic approaches that suppose the "subject" to be the central category, since it is understood as a category derived from the ideology's materiality. In this new framework, ideology -with a material and imaginary nature- has the central function of constituting individuals as subjects through a complex mechanism that will be called ideological interpellation.

Finally, we aim to point a limit in Althusser's proposal: it is unable to give an account of the specific mechanisms that operate in the processes of constitution of gendered subjectivities. However, if we make a symptomatic reading about Althusser's own silence, we can give rise to a new problem: the articulation between ideology and gender, a problem that is becoming more and more important nowadays.

Key words: ideology, subjectivation, symptomatic reading, gender. 


\section{Agradecimientos}

Para empezar, agradezco enormemente a mis padres por apoyarme en todos mis proyectos. A mis hermanxs, mis cómplices. A mis sobrinos: Carmela, Dante y Alfonsina, que me han permitido ver con alegría, nuevas preguntas filosóficas.

A mi tía Nora por su templanza.

A Nacho por el andar y la calma.

A Milonga y a Zamba, porque son también mi refugio.

A mis amigxs con quienes comparto camino hace varios años: Vecha, Dani, Euge, Ro, Carlita, Fer, Bel, Meli, Nati, Mari, Jose, Pau, Ele, Laurita, Ana P, Juli, Romi, Vivi y Cele. A las "brujitas" de México: Andre, Linda, Karlita y Liz, con quienes comprendí que un encuentro es aquel que es capaz de durar.

A Pedro y a Oscar, mis directores, por la confianza y por alentarme en todo momento.

A lxs colegas del taller de tesis, con quienes nos hemos dado ánimo mutuamente; a Sofi Calvente, por su generosidad. A mis compañerxs de cátedra con quienes buscamos nuevas formar de filosofar.

A mis alumnxs, porque son 1xs culpables de que surjan nuevas sospechas.

Al Doctorado de Filosofía de la Facultad de Humanidades y Ciencias de la Educación por la predisposición a colaborar en todo momento. A Juani Veleda por la paciencia.

A CONICET por financiar estos estudios.

A la Universidad pública y gratuita.

A Mariflor Aguilar Rivero, y su grupo de investigación en la UNAM con quienes tuve el gusto de debatir argumentos aquí presentados.

A las integrantes del grupo de extensión, por la empatía y el enorme compromiso de querer construir colectivamente lazos y saberes transformadores.

A la Coordinadora Feminista $8 \mathrm{M}$ de Chile con la que pude compartir reflexiones sobre uno de los procesos más disruptivos a los que asistimos en Latinoamérica.

A lxs que luchan y resisten con dignidad.

A todxs los que colaboraron de una $\mathrm{u}$ otra manera en este proceso intenso. Gracias infinitas.

Finalmente, dedico este trabajo a Luz, mi madre; que, entre muchas cosas, cuando me enseñó a manejar, me hizo un guiño para que persevere en mis deseos. 


\section{Método de Citas y Abreviaturas}

El método de cita escogido es el APA (Apellido, año de edición, paginación). Sin embargo, en el caso de las obras más utilizadas en nuestro trabajo, utilizaremos abreviaturas que se compondrán de las iniciales de la obra. Y que detallaremos a continuación.

\section{Abreviaturas}

\section{De obras de Althusser}

. La Revolución teórica de Marx (RTM, 1968) dentro de la que se encuentran los textos: "Marxismo y Humanismo" (1963); “Los Manifiestos filosóficos de Feuerbach” (1964); "Sobre la dialéctica materialista" (1964); "Contradicción y sobredeterminación” (1962); “Sobre el Joven Marx” (1960); “El ‘Piccolo’, Bertolazzi y Brecht” (1962).

. Escritos sobre Psicoanálisis (EP, 1996) dentro de la que se encuentran los textos utilizados: "Freud y Lacan" (1964); "Cartas a Diatkine" (1966); "Tres notas sobre la teoría de los discursos" (1966).

. La soledad de Maquiavelo (SM, 2008) dentro de la que se encuentran los textos utilizados: "Tesis de Amiens" (1975); "El marxismo como teoría finita" (1978).

. Psicoanálisis y Ciencias Humanas (P y CH [1963- 1964] 2014)

. Para leer El capital (PLC [1965] 1968)

. "Sobre la génesis" (SG [1966] 2013)

. Curso de Filosofía para cientificos (CF [1967] 1975)

. La filosofía como arma para la revolución (FAR [1968] 1974)

. "La querella del humanismo" (QH [1968] 1994)

. Lenin y la filosofía (L y F [1969] 1970)

. Ideología y aparatos ideológicos del Estado (IAEI [1970] 1988)

. Sobre la Reproducción (SR, [1970] 2015)

. Para una crítica de la práctica teórica (PPT [1973] 1974)

. Elementos de autocrítica (EA [1974] 1975)

. Iniciación a la filosofía para los no filósofos (IF [1975] 2015)

. Ser Marxista en Filosofía (SMF [1976] 2017)

. Marx dentro de sus límites (MDL [1978] 2003)

. La Corriente subterránea del materialismo del encuentro (ME [1982] 2002)

. "La única tradición materialista" (UTM [1985] 2007) 
. El porvenir es largo (EPL [1986] 1992)

\section{De obras primarias de Marx}

La ideología alemana (LIA [1845] 2005)

El Capital (EC [1871] 2015)

Introducción a los Elementos Fundamentales para la crítica de la economía política(borrador) 1857-1858, (I, 2002)

\section{De obras primarias de Spinoza}

Ética (E [1677] 2002)

Tratado teológico- político (TP [1670] 2003)

\section{De otros autores}

Slavoj Zizek. El sublime objeto de la ideología (SOI [1989] 2009)

Jacques Lacan. El Estadio del Espejo (EE [1949] 2010)

En el caso de El Capital (EC) citaremos: Libro (L) en números romanos, luego el tomo (t.) también en números romanos; el volumen en números arábigos (vol.); y finalmente la página/ s (p. /pp.) en números arábigos también. Ejemplo: EC, I, I, vol.1, p. 19. Las citas utilizadas son las de la traducción al español de Pedro Scaron, Editorial Siglo XXI, 2015, consignada en la bibliografía utilizada.

Para las citas de la Ética demostrada según el orden geométrico(E) se indicarán las partes en números romanos (E, I; II, etc.); las definiciones (def.) y las proposiciones (prop.) en arábigos señalándose con abreviaturas las explicaciones (expl.), los axiomas (ax.), las demostraciones (dem.), los corolarios (cor.), los escolios (esc.), los lemas (lem.). Ejemplo: E, I, def. 5; p.13.Las citas utilizadas son las de la traducción al español de Atiliano Domínguez, edición Trotta, $3^{\circ}$ edición, año 2009, consignada en la bibliografía utilizada.

En el caso del Tratado teológico- político $(T P)$ se indicará TP, capítulo y parágrafo en números arábigos. Las citas en español también corresponden a Atiliano Domínguez, Editorial Alianza, 2003. 


\section{INTRODUCCIÓN}

El problema de la ideología tiene un estatuto central en la propuesta filosófica de Louis Althusser, quien inscribe el concepto en una perspectiva materialista ("la ideología tiene una existencia material") haciendo una importante demarcación con los abordajes idealistas que la ubican en la dimensión de la interioridad subjetiva.

En el nuevo marco, la ideología tiene por función central la constitución de los individuos como sujetos mediante el complejo mecanismo de la interpelación ideológica, que es tanto de subjetivación como de sujeción. Analizar la interpelación ideológica en tanto función central de la ideología inscripta en bases materialistas, constituye el objetivo central de este trabajo.

Efectivamente, en el marco de la teoría materialista de la ideología propuesta por Althusser, el sujeto (ideológico) es comprendido como un efecto de la práctica de la interpelación ideológica que -articulada con la estructura social- tiene por función central garantizar que los individuos ocupen los lugares que se ha dispuesto para ellos dentro de una formación social concreta. De manera que, la materialidad de la ideología involucra también la materialidad del sujeto, en tanto efecto de las estructuras sociales; así como implica comprender que ambas categorías (la de ideología y la del sujeto) se encuentran en una relación de inmanencia, puesto que: "no hay ideología sino por el sujeto y para los sujetos; y sólo hay sujetos por y para la ideología” (IAEI: 51).

En este sentido, cabe señalar que el pensamiento de Althusser -inscripto en una reflexión filosófica contemporánea- cuestiona la concepción de un Sujeto constituyente, y lo colocaen un nuevo terreno: el de las estructuras y los procesos sociales que anteceden al sujeto. Este carácter derivado del sujeto (en contraposición al del sujeto como Fundamento) es transversal en la intervención materialista althusseriana, y adquiere diversas formas como la tesis del antihumanismo teórico, que se encuentra presidida por este cuestionamiento transversal a la categoría de sujeto como fundamental.

La polémica tesis del antihumanismo teórico es formulada por Althusser para trazar una demarcación con las problemáticas ideológicas en las que la "esencia humana" opera como fundamento teórico de ideologías como la del humanismo teórico-que comienza a dominar el campo ideológico de la época ${ }^{1}$. Proponemos

\footnotetext{
${ }^{1}$ Entre los principales representantes se encuentra Erich Fromm junto con otros pensadores, quien luego de la crisis del marxismo, que había sido considerado culpable por las experiencias de los socialismos
} 
mostrar, en este sentido que, la tesis del antihumanismo teórico es una pieza fundamental de la intervención materialista de Althusser; y opera en articulación con otras formulaciones que le son subsidiarias-como la del proceso sin sujeto ni fines, el rechazo a la génesis como origen- que rechazan (aunque no de manera monolítica) la categoría de sujeto entendido como Origen, Fin y Fundamento. Mostraremos que, tal posicionamiento materialista implica a su vez:

1) el rechazo al tratamiento idealista de la lectura que la comprende como lineal, inmediata e ingenua.

2) el rechazo a la concepción tradicional del conocimiento, de tipo empirista, en la que este es comprendido como el resultado de la relación preestablecida entre un sujeto y un objeto;

3) subsidiariamente, la comprensión del conocimiento como el resultado de un proceso de producción, que distingue entre objeto de conocimiento y objeto real;

4) la ruptura con las interpretaciones historicistas; para comprender la historia como un proceso sin sujeto ni fines, motorizada por la lucha de clases.

5) la comprensión de la práctica filosófica como lucha de clases en la teoría.

La hipótesis general de la presente investigación consiste en que la formulación althusseriana de la práctica de la interpelación ideológica constituye una respuesta a una cuestión no planteada desde marcos idealistas: ¿cómo se constituyen los individuos en sujetos? Con la cual Althusser no sólo repone un silencio de los abordajes que dan por supuesto al "sujeto", sino que además refuerza su posicionamiento materialista en filosofía que implica una demarcación con el tratamiento idealista de la ideología y del sujeto.

Ahora bien, aunque existe en la propuesta de Althusser, un predominio en destacar la materialidad de la ideología y la articulación de esta con la estructura social, no se trata de un concepto homogéneo ni monolítico ya que existen diversas acepciones dentro del corpus althusseriano (así como fuera de la tradición marxista).Entre las diversas acepciones se encuentra la definición de la ideología como "la relación vivida de los hombres con su mundo", como "una conciencia del mundo", como "una conciencia de sí, de una sociedad o de un tiempo", como "un sistema de ideas unificadas que actúan sobre las conciencias", entre otras. En todas estas acepciones se destaca la función práctico- social de la ideología. Desterrada de los resabios idealistas 
que se encontraban en la concepción de la ideología entendida como "falsa conciencia", “ilusión errónea", "sueño" o "mera quimera".

Esta demarcación es realizada por Althusser a partir de una lectura sintomática que distingue entre una problemática ideológica en el pensamiento del joven Marx, puesto que la ideología se encontraría comprometida con supuestos representacionalistas, $\mathrm{y}$ en el fondo idealistas. $\mathrm{Y}$ una problemática científica, que se inauguraría a partir de La ideología alemana, en la que Marx según Althusser, rompería con su concepción ideológica anterior. Pero, la ruptura no es total, ya que persisten resabios mecanicistas y positivistas, en el fondo idealistas ("una concepción no marxista de la Ideología”) en esta obra de 1845. Ya que allí la ideología es también presentada como una ilusión, como puro sueño puesto que "toda su realidad está fuera de ella misma" (LIA: 32). Lo cual, acarrea el error idealista de pensar que la falsedad de las ideas podría erradicarse voluntaria y libremente (Williams, 2000). Sin embargo, Marx enfatiza que esos "fantasmas", "espectros", "visiones" "sólo pueden disolverse por el derrocamiento práctico de las relaciones sociales reales, de que emanan estas quimeras idealistas" (LIA: 40). Puesto que, "no es la conciencia la que determina la vida, sino la vida la que determina la conciencia" (Ibíd.: 26).

Althusser ve en estas tesis de Marx, el inicio de una ruptura teórica con el abordaje idealista de la ideología, y propone inscribir el concepto en bases materialistas. En ese sentido, Althusser propone comprender a la ideología a partir de su existencia material, a través de prácticas y discursos que tienen la función de garantizar el dominio de la ideología de las clases dominantes. El énfasis colocado en la función práctica y social de la ideología, ya se encuentra en Marxismo y humanismo de 1963, y es profundizado en Ideología y aparatos ideológicos del Estado, donde la ideología es un sistema de representaciones que existen en un determinado aparato ideológico que prescribe prácticas concretas a los sujetos, dado que: "la ideología es la representación imaginaria que se hacen los hombres acerca de sus condiciones reales de existencia" (IAEI: 45).

Efectivamente, en Ideología y aparatos...la ideología pasa a ser reformulada como la relación necesariamente imaginaria entre los individuos y sus condiciones de existencia. El carácter imaginario de la ideología -que refiere al objeto que es "representado" por la ideología- implica una lógica de reconocimiento/ desconocimiento, puesto que las prácticas que los individuos creen que realizan por su libre voluntad, en realidad, están determinadas con anterioridad; de acuerdo a las 
demandas de la estructura social. Develar este mecanismo, involucra realizar un rodeo en torno a lo imaginario que remite tanto al psicoanálisis lacaniano como a lo que Althusser llama el "materialismo de lo imaginario" de Spinoza.

Ahora bien, el hecho de que la materialidad de la ideología se despliegue a través de los aparatos ideológicos del Estado (AIE) -puesto que "existe siempre en el aparato que es su realización"- implica reconocer el funcionamiento de la ideología en su articulación con la reproducción de las condiciones de producción. En este marco, la ideología garantiza las prácticas requeridas por el sistema capitalista a través de la subjetivación/ sujeción de individuos como "sujetos" asegurando la reproducción de la ideología de las clases dominantes.

El carácter necesario de la articulación entre la reproducción de las relaciones capitalistas de producción y la ideología a través de su función de interpelación; y la necesariedad de la inmanencia de la ideología con sus prácticas, se vincula profundamente con el carácter transhistórico de la ideología que -al igual que el inconsciente, que es eterno- "ha existido y existirá siempre. Podrá cambiar de contenido, pero nunca cambiará de función"” (F y M: 75). Esta Ideología omnihistórica, general, se distingue de las ideologías particulares como la religión, la moral, la política; que son históricas, particulares y concretas.

Hasta aquí entonces: la concepción de la ideología como material e imaginaria permite comprender su materialidad a través de las prácticas que prescriben los AIE; así como dar cuenta de una de sus funciones centrales: la constitución de los individuos como sujetos. Este efecto material de la ideología: el "sujeto", se encuentra formando parte de un entramado complejo en el que se articula, por un lado, la ideología y las demandas de la estructura social; y por otro, la ideología y el dispositivo que asegura la respuesta de los individuos al llamado de la interpelación ideológica, que es lo que ocurre en la mayoría de los casos, según el diagnóstico althusseriano (“con excepción de los malos sujetos").

Para llevar a cabo los objetivos propuestos, en la primera parte nos centraremos en la lectura de Marx por Althusser, la que, bajo el interés de renovar el marxismo, implicó desmontar las lecturas humanistas -por entonces hegemónicas- que obturaban

\footnotetext{
${ }^{2}$ Lo que ha suscitado diversas críticas al "funcionalismo" de Althusser. También múltiples han sido las respuestas de Althusser. Como la que se encuentra en Sobre la Reproducción donde se afirma que "la lucha de clases es incompatible con todo funcionalismo" (SR: 257). O también en Iniciación a la Filosofia (IF: 143-159).
} 
dimensionar la magnitud del descubrimiento científico de Marx. Tal descubrimiento se manifiesta, según la lectura althusseriana, en el estado latente de determinados conceptos, que Althusser formula "con todas las letras", como el de causalidad estructural (heredero según la lectura althusseriana, de la causalidad inmanente de Spinoza); el de determinación en última instancia, y el de contradicción sobredeterminada. Proponemos mostrar en este sentido, que existe un hilo vertebrador en la obra althusseriana: su posición materialista en filosofía que se manifiesta en el rechazo transversal del Sujeto como Origen, Fin y Causa. Este posicionamiento de Althusser concuerda con su propósito de recomenzar la problemática materialista en filosofía en un campo de batalla (Kampfplatz). Y consecuentemente, con su propósito de combatir los tratamientos idealistas entendidos como un obstáculo epistemológico para dimensionar las potencialidades de la teoría de Marx.

En la segunda parte de este trabajo examinaremos que la ideología entendida desde su materialidad tiene la función central de interpelar a los individuos como "sujetos", para que ocupen determinados lugares en la estructura social. En este sentido, mostraremos que es la propia práctica de la interpelación ideológica la que permite desmontar el abordaje ideológico de la ideología, y el tratamiento idealista del sujeto. Ya que lo que la interpelación ideológica demuestra que el sujeto es siempre ya sujeto, en tanto está "sujeto" incluso antes de nacer, a una determinada configuración ideológica. En este sentido, atenderemos a la articulación fundamental que existe entre la ideología y el inconsciente desarrolladas por Althusser principalmente en Freud y Lacan (1964), en Psicoanálisis y Ciencias Humanas (1963-1964), en las Cartas a D (1966) y en las Tres notas sobre la teoría de los discursos (1966).

Al explorar la práctica de la interpelación ideológica, atenderemos también a su genealogía ${ }^{3}$, sus usos, derivas teóricas y límites. En este sentido, enfatizaremos el hecho de que la primera aparición del término se encuentra en las Tres notas sobre la teoría de los discursos, donde la elucidación del mecanismo de la interpelación ideológica se inscribe en una teoría materialista de los procesos discursivos, como un modo de conceptualizar la ideología. Lo que ubica, inicialmente, a la interpelación ideológica dentro de la problemática de la teoría de los discursos, que luego es abandonada.

\footnotetext{
${ }^{3}$ Interpeller es entendida como la acción policial de detener a un individuo, es una acción que toma la forma de un mandato. Es un acto de habla necesariamente arraigado no sólo en un contexto legal específico sino en una relación de fuerzas desigual para proveer la prueba de identidad necesaria.
} 
Efectivamente, la primacía del carácter discursivo de la interpelación ideológica en las Tres notas desaparece en Ideología y aparatos... donde se destaca el estatuto de las prácticas concretas que garantizan el funcionamiento de la ideología, y de los sujetos, que sólo podrán ser sujetos en tanto inscriptos en una práctica social. Lo que ha suscitado interpretaciones funcionalistas y reproductivistas, vinculadas a la circularidad de la estructura ideológica. Nos centraremos en las críticas que Zizek y Butler realizan al planteo de la interpelación ideológica en Ideología y aparatos... atendiendo a la falta de agencia de los sujetos, a lo que atribuyen factores distintos.

Examinaremos comparativamente la propuesta de la interpelación ideológica en las Tres notas y en Ideología y aparatos...para mostrar que, en las primeras, la función de la ideología es interpelar a los individuos como sujetos; transformando la función Träger impersonal en función- sujeto, por la articulación entre las instancias económico- social e ideológica. En este marco, el discurso ideológico produce una forma subjetiva que requiere a su Träger (soporte) individual presente en persona, por ello la posición "sujeto" solo compete al discurso ideológico. Y es una posición que se configura en cada caso singular, no anticipadamente.

Con el examen de las Tres notas pretendemos mostrar que la articulación central que allí existe entre el discurso ideológico con el discurso del inconsciente posibilita explicar la respuesta a un mandato y la identificación con el Significante amo, mediante la persuasión discursiva. Lo que, constituye una respuesta frente a las críticas de Zizek y de Butler. Sin embargo, este abordaje de las Tres notas de la ideología desde una teoría materialista de los discursos, se diluye en Ideología y aparatos...

Por otra parte, propondremos mostrar frente a las críticas que recibe el planteo de la interpelación ideológica en Ideología y aparatos...que estas pueden ser respondidas al atender a la articulación esencial entre ideología e inconsciente; así como al destacar la primacía de la lucha de clases presente desde el principio en los AIE, énfasis que aparece con mayor vigor en Sobre la Reproducción, de la que es extractado Ideología y aparatos...

Sin embargo, argumentaremos que ni en las Tres notas..., ni en el ensayo Ideología y aparatos... aparece una preocupación por parte de Althusser en torno a los mecanismos específicos mediante los que se producen las subjetividades generizadas. Frente a este silencio teórico, proponemos realizar una lectura sintomática -aplicando al propio lapsus de Althusser el protocolo de lectura que él propone- así como leeremos críticamente su abandono de una concepción materialista de los discursos, cuyo síntoma 
se encuentra en el equívoco althusseriano al final de la nota 3 , al sostener que los discursos "no ejercen eficacia sobre objetos reales" (EP: 143).

En estas discontinuidades, para nosotros, emerge la necesidad de indagar en torno a la compleja relación entre "ideología y género", atendiendo al estatuto central de los discursos. En este sentido, retomaremos algunas perspectivas feministas que han abordado explícitamente la problemática de la articulación entre ideología y género; insistiendo en la efectividad de los procesos ideológicos discursivos en diversos marcos -tecnología de género; sistema sexo/ género; patriarcado; colonialidad de género-en los que se producen las subjetividades con género. Esta lectura crítica, será el eje de la tercera parte de nuestro trabajo.

En efecto, en la tercera y última parte de nuestro trabajo, leeremos críticamente el abandono por parte de Althusser de la teoría materialista de los discursos; así como leeremos críticamente, el silencio de Althusser en torno a los procesos y mecanismos específicos mediante los que se producen las subjetividades generizadas; las que quedan sujetadas a lugares específicos de la estructura social, donde existen jerarquías por género.

En este sentido, proponemos mostrar que el género es una estructura diferencial que se articula con la ideología. Y que al articular ideología y género es posible dar cuenta de los mecanismos específicos que constituyen a los "sujetos con género"; en los que, los discursos, entendidos desde su materialidad, juegan un rol central. Lo que pretendemos seguir desarrollando y profundizando en futuras investigaciones.

En términos metodológicos, la presente investigación propone una lectura crítico- política que implica una reconstrucción histórica; y un análisis conceptual. La perspectiva de enfoque adoptada propone poner en juego de manera simultánea una intención expositiva y explicativa. En este sentido analizaremos las conceptualizaciones centrales de la intervención materialista de Althusser, como matriz para comprender la tesis central de su teoría materialista de la ideología: la de la interpelación ideológica. Por otra parte, atenderemos al contexto ideológico- político de su producción teórica, así como a algunas discusiones, críticas y derivas que ha suscitado su reformulación de la ideología, y más precisamente, la de la práctica de la interpelación ideológica.

En esta dirección, reconstruiremos las tesis centrales de la teoría de la ideología de Althusser, así como posibles respuestas a las críticas que recibe, en los propios términos del autor, así como en las perspectivas de otros autores, y en las nuestras. 
Hacia el final de nuestro trabajo, aplicaremos el protocolo de lectura propuesto por Althusser, sobre discontinuidades y lapsus que vemos en su propio discurso; para poder dar lugar a una nueva problemática, la de la articulación entre ideología y género, y para plantear una pregunta no formulada: ¿mediante qué mecanismos se producen las subjetividades con género?

Los procedimientos a seguir serán:

ii) Explorar el pensamiento althusseriano en tanto pensamiento situado en una coyuntura específica y en un contexto histórico-filosófico- concreto.

iii) Mostrar sus filiaciones, influencias, herencias y vinculaciones con otras corrientes de pensamiento, entre las que se destaca el vínculo con el psicoanálisis, cuya noción de inconsciente es central para comprender la dimensión imaginaria de la ideología. Así como el legado de una corriente filosófica materialista "subterránea", donde se destaca la figura de Spinoza.

Todo ello para dar cuenta de que:

1) La intervención materialista de Althusser es fructífera para examinar y explicar problemas sociales actuales, dando lugar a cuestionamientos como: ¿bajo qué mecanismos los individuos se comportan de acuerdo con las demandas requeridas por la estructura económico- social? ¿Qué relación existe entre la ideología y la respuesta a los mandatos sociales? ¿Cómo se mueven los cuerpos sujetados hacia determinados objetos de deseo?

2) la ideología desde una perspectiva materialista propuesta por Althusser logra no sólo eludir las dificultades que acechan al concepto de ideología si se la comprende como mera mistificación y representación falsa. Ya que, al caracterizar a la ideología como relación necesariamente imaginaria, Althusser nos ofrece una respuesta en torno a los procesos y mecanismos mediante los cuales se produce la constitución de sujetos. En este sentido, el mecanismo de la interpelación ideológica es una práctica con carácter necesario para garantizar la permanencia de la ideología dominante, cuya materialidad reside en constituir posiciones- sujetos que ocupen los lugares de la estructura social requeridos por el sistema capitalista.

3) Al realizar una lectura sintomática sobre el propio pensamiento de Althusser, es posible dar lugar a una nueva problemática: la de la articulación entre la estructura de la ideología y la estructura diferencial del género.

Los objetivos propuestos serán desplegados a lo largo de las tres partes que constituyen el presente trabajo. La primera dando cuenta de la lectura de Marx por 
Althusser y de las bases centrales de la intervención materialista de Althusser. En la que ocupa un lugar central la tesis del antihumanismo teórico de Marx, que se remonta al antihumanismo filosófico de Spinoza. La segunda parte, se centra en la tesis de la interpelación ideológica tal como es planteada en Ideología y aparatos...y algunas de las críticas que recibe este planteo; centrándonos en las críticas de Zizek y de Butler. En esta parte evaluaremos que el tratamiento que Althusser hace de la interpelación ideológica en las Tres notas... logra eludir (anticipadamente) muchas de las dificultades que se le presentan al planteo del ensayo de 1970.Mientras que, finalmente, en la tercera parte, proponemos realizar una lectura sintomática sobre la ceguera de género de Althusser, con el interés de indagar en torno a los mecanismos específicos mediante los que se producen las subjetividades generizadas.

La primera parte titulada "La ideología desde una perspectiva materialista" busca mostrar y examinar tesis materialistas transversales de la intervención de Althusser. Está integrada por tres capítulos: en el capítulo I "Lectura de Marx por Althusser" analizaremos que la práctica materialista de lectura propuesta por Althusser permite dimensionar el cambio de problemática y la ruptura epistemológica con la problemática idealista en el pensamiento de Marx. Mostraremos asimismo que, para lograr dimensionar la ruptura llevada a cabo por Marx, Althusser plantea una tesis radical -la del antihumanismo teórico de Marx- para impedir el avance de lo que considera un obstáculo epistemológico: las lecturas humanistas del pensamiento de Marx que además de impedir dimensionar lo que Althusser considera, los aportes centrales de la teoría de Marx; enmascararían las causas profundas de crisis del marxismo, y, por tanto -según Althusser- dificultan resolverlas.

En el capítulo II "El conocimiento científico del todo complejo sobredeterminado" pretendemos examinar que el todo marxista es complejo y desigual, y que lo que es determinante en última instancia es la lucha de clases económica. Para ello, examinaremos el modo de producción (materialista) de conocimiento: la práctica teórica. Así como examinaremos la causalidad estructural y la casualidad inmanente, la determinación en última instancia y las características de la dialéctica marxista, desigual y sobredeterminada. Mientras que, el capítulo III titulado "La filosofía como lucha de clases en la teoría" propone exhibir la transversalidad de la lucha de clases como motor de la historia y como elemento central de la intervención materialista de Althusser.

La segunda parte titulada "Ideología y subjetivación" se compone de cuatro capítulos. El primero de ellos (el capítulo IV) se titula "La ideología con existencia 
material e imaginaria" donde examinaremos que, en el marco de la teoría materialista de Althusser, la ideología se encuentra articulada de manera fundamental con la estructura social, y con la estructura del inconsciente.

El capítulo V se titula "la interpelación ideológica en Ideología y aparatos...", para distinguirlo del abordaje que tiene la interpelación en el marco de las Tres notas...En este capítulo examinaremos la estructura de la ideología; así como el mecanismo de subjetivación/ sujeción de la práctica de la interpelación ideológica y su función de reconocimiento ideológico cuyo reverso es el desconocimiento ideológico, que indagaremos como parte de la articulación entre ideología e inconsciente; principalmente a través de los desarrollos de "Freud y Lacan", "Psicoanálisis y Ciencias humanas", y en "Cartas a D..."

En el capítulo VI titulado "Críticas a la interpelación ideológica de Ideología y aparatos" examinaremos algunas de las críticas que recibe el planteo de la interpelación ideológica tal como es presentado en el ensayo de 1970; entre las que se destacan las de Zizek y de Butler. Frente a estas críticas, postularemos algunas respuestas y alternativas como la de destacar la primacía de la lucha de clases en los AIE, que posibilitan la transformación de las relaciones sociales de producción. Así como la posibilidad de que se produzcan otro de tipo de interpelaciones. En este sentido, examinaremos la propuesta de Pêcheux de distinguir entre identificaciones, contraidentificaciones y desidentificaciones.

Mientras que en el capítulo VII titulado "la interpelación ideológica como persuasión discursiva" analizaremos la propuesta de la interpelación ideológica en su formulación inicial: Las tres notas..., donde la práctica de la interpelación ideológica consiste más bien en una empresa de persuasión, en la que tienen un estatuto central los discursos ideológicos, entendidos desde su materialidad, ya que posibilitan articular la estructura de la ideología y la estructura del inconsciente.

La tercera parte se titula "Ideología y género" y se compone de dos capítulos: el capítulo VIII "Althusser dentro de sus límites" en el que argumentamos nuestra crítica sobre el silencio de Althusser en torno a la estructura diferencial del género, precisando nuestras lecturas culpables para dar lugar a una nueva problemática.

En el capítulo IX titulado "La ideología de género" proponemos establecer una demarcación entre el abordaje de la cuestión desde un abordaje de la teoría feminista como el que realiza Teresa de Lauretis-; del uso de la expresión desde sectores que buscan el rechazo a lo que representan como "ideología de género". Frente a este 
proceso ideológico- discursivo, proponemos trazar genealogías feministas críticas del género, y desde el sur; y recomplejizar el concepto, circunscribiéndolo en perspectivas materialistas críticas, inclusivas e interseccionales.

Cabe señalar que, las conclusiones finales se compondrán estrictamente de las conclusiones preliminares de cada una de las tres partes que constituyen nuestro trabajo.

Por último, con esta investigación proponemos no sólo aportar elementos para abonar a la perspectiva filosófico- materialista en torno de los procesos de subjetivación/ sujeción. Sino que proponemos también leer filosóficamente algunos silencios sintomáticamente ausentes para dar lugar a una nueva problemática: la de la articulación entre ideología y género, que en la coyuntura teórico- política actual se torna urgente, y nos interpela para intervenir filosóficamente. 
PARTE I. LA IDEOLOGÍA DESDE UNA PERSPECTIVA MATERIALISTA 


\section{Capítulo I. Lectura de Marx por Althusser}

...el alma viva del marxismo es el análisis concreto de la situación concreta...

(Althusser, Tesis de Amiens)

En este capítulo proponemos mostrar que la lectura de Marx por Althusser, es una lectura filosófica y materialista, que lleva a cabo un movimiento de ruptura con el tratamiento idealista de la ideología que coloca al sujeto como centro y fundador del conocimiento y las representaciones.

Frente a lo cual, la posición materialista de Althusser comprende al sujeto como efecto de las estructuras económicas, sociales y políticas, efectuando una demarcación con las lecturas ideológicas de los textos de Marx, como la del humanismo teórico, subsidiaria de una concepción historicista de la historia y una concepción empirista del conocimiento.

Proponemos mostrar como segundo objetivo de este capítulo: que la lectura de Marx por Althusser implica también un retorno a la filosofía de Spinoza. Pero, “¿Por qué este rodeo?" (EA: 45). 


\section{Práctica materialista de la lectura}

Ser materialista es "no contarse cuentos", porque las historias impiden reconocer "la cartografía básica de un mundo articulado sobre el poder de clase, porque dibujan, por el contrario, un horizonte plano en el que permanece 'sujeto' cualquier deseo de

socialidad.

(Althusser, Marx dentro de sus límites)

El "regreso a Marx" que propone Althusser en Para leer el Capital ${ }^{4}$ ([1969] 2004) implica realizar una lectura filosófica de El Capital (EC) y los Gründisse capaz de leer lo no dicho en la literalidad del discurso de Marx, viendo en entrelíneas la novedad de una nueva problemática. Se trata, como el propio Althusser destacó, de hacer una lectura culpable, capaz de producir una serie de lecturas dobles a partir de las discontinuidades del discurso de Marx $^{5}$.

Esta práctica de lectura tendría sus antecedentes en Marx, Nietzsche y Freud quienes instaurarían la sospecha de lo que quiere decir [veut dire] escuchar, por lo tanto, lo que quiere decir hablar (y callarse). Descubriendo "bajo la inocencia de la palabra hablada y escuchada, la profundidad de un segundo discurso: el discurso del inconsciente" (PLC: 21).

En el caso de Marx, según Althusser, esta práctica de lectura implica la ruptura con un tipo de lectura lineal e ingenua que acecha, por ejemplo, a los Manuscritos de 1844 en la que Marx "lee a libro abierto", la esencia humana en la trasparencia de su alienación. Mientras que, en El Capital Marx realizaría una lectura doble, inaugurando

\footnotetext{
${ }^{4}$ Forma parte de la obra colectiva Lire le Capital (LC) en la que escriben también Roger Establet, Pierre Macherey y Jacques Ranciére. Este ensayo es la transcripción de un seminario desarrollado en la École Nomale Supérieure (ENS) de la rue d 'Ulm, durante el año escolar 1964-1965 bajo la dirección de Louis Althusser, quien ejercía allí las funciones de un "preparador asociado" y de secretario de la sección Letras. Sin embargo, debido a posicionamientos políticos diferentes entre los autores desde 1968, el editor François Máspero propuso una edición en dos tomos más pequeños. Por elección de Althusser, esos dos tomos se limitaron finalmente a su propia contribución y a la de Étienne Balibar: t. I: L. Althusser: Prefacio: "de El capital a la filosofía de Marx"; L. Althusser "El objeto de El capital", caps. I a V; t. II: L. Althusser "El objeto de El capital" (continuación), caps. VI a IX, Apéndice; E Balibar: "Sobre los conceptos fundamentales del materialismo histórico" (Ídem.).

${ }^{5}$ Para Tosel, Althusser como filósofo autocrítico de la filosofía, ha querido darle al materialismo histórico la forma de la cientificidad con la cual la teoría del modo de producción capitalista, objeto de El capital, abrió la ciencia del continente de la historia, explicitando su estructura conceptual, la dinámica interna, las leyes de tendencia y la transformación posible en otro modo de producción (Tosel, 2015: 1).
} 
un nuevo discurso, el discurso del inconsciente, que permite descubrir el significado de aquello que se calla, que se omite y que se oculta ${ }^{6}$.

Entonces bien, bajo este protocolo de lectura, a partir de 1845 Marx "cambia de terreno" y rompe con la lectura inmediata- de la que Marx habría estado preso en su juventud- tributaria de la concepción hegeliana del todo como totalidad expresiva: "El Saber absoluto" que se expresa de forma inmediata en cada una sus partes ${ }^{7}$. Y a la que se podría acceder mediante un "ver" empírico, disponible a una mirada informada, tal como lo es el leer al pie de la letra (Ídem). El "mito religioso de la lectura" (Ibíd.: 22) entonces, se vincula según Althusser con el empirismo (que acecha a ciertos abordajes idealistas) cuando confía en que "una mirada atenta" le permitiría al lector acceder a un texto en sí mismo transparente.

Frente a lo cual Althusser propone una lectura capaz de ver en entrelíneas, de transgredir un límite en la propia letra de Marx; siguiendo en ello a Spinoza, quien propone leer las Escrituras como se lee la naturaleza, atendiendo a sus lagunas y saltos; atendiendo a un discurso latente que se manifiesta a través de sus carencias. Estas discontinuidades, funcionan como síntomas del segundo discurso que se articula sobre los lapsus del primero, posibilitando una lectura simultánea de dos alcances: mientras que la primera es una lectura literal; la segunda "detecta lo indetectable en el propio texto que lee y lo relaciona con otro texto presente con una ausencia necesaria en el primero" (Ibíd.: 23).

Ahora bien, bajo la perspectiva althusseriana, esta práctica de lectura se encontraría en la lectura doble que Marx realiza de los economistas políticos clásicos, Smith y Ricardo. La primera de estas lecturas es realizada según Althusser, a través del propio discurso de Marx. Cuyo resultado es una lectura teórica retrospectiva según la cual las deficiencias de la economía política clásica se reducen a un defecto del ver, presuponiendo que el objeto es inmediatamente accesible, "transparente a la mirada del hombre" (PLC: 24). Mientras que la segunda lectura es completamente distinta a la primera, es una lectura que nos permite ver en entrelíneas lo que no vieron los economistas ingleses, pero de manera que "es el texto clásico mismo el que nos dice lo

\footnotetext{
${ }^{6}$ Este discurso del inconsciente, que Althusser encuentra en Marx, sin lugar a duda, vincula a la impronta althusseriana con los aportes provenientes del psicoanálisis de Freud, y principalmente de Lacan en cuanto han analizado los síntomas de la estructura oculta del inconsciente (Ver: Callinicos, 1978: 35-37).

7 "la Verdad última del ser en cada manifestación fenoménica, en cada ente o acontecimiento, pues, toda parcialidad está 'llena' de la presencia de la Totalidad que la habita (como "Dios está en todas las cosas")" (Gainza, 2013: 13).
} 
que se calla: su silencio con sus propias palabras" (ibíd.: 27). Es así que Marx puede plantear una pregunta fundamental: “¿cuál es el valor del trabajo?” pregunta que "se hace culpable de una inadvertencia ${ }^{8}$ singular de Smith y Ricardo, quien no ven lo que precisamente ven: la función determinante de la fuerza de trabajo, reemplazándola por la ilusoria noción del valor del trabajo, en el análisis del valor en general ${ }^{9}$.

En este sentido, Althusser argumenta que los economistas clásicos al preguntarse sobre el costo de producción del obrero, "inconscientemente confundían este problema con el primitivo, pues se limitaban a dar vueltas y más vueltas alrededor del costo de producción del trabajo como tal, sin moverse del sitio", ya que: "lo que ella llama valor del trabajo (value of labour) es, en realidad, el valor de la fuerza de trabajo” (ibíd.: 25).

Sin embargo, ha sido Marx en la lectura de Althusser, quien -al romper con el mito religioso de la lectura (que es también una ruptura con la concepción hegeliana del todo como totalidad")- pudo formular la pregunta que la economía clásica no plantea (pero de la que, sin embargo, dan respuesta). A propósito de este desacierto, Engels en su Prefacio al Libro II de El capital afirma: "lo que ellos (los economistas clásicos) habían contemplado como solución, él la consideraba como un problema" (Cfr. Callinicos, 1978: 33-34). Por su parte Althusser, lo interpreta de la siguiente manera:

Marx puede formular la pregunta no enunciada, enunciando simplemente el concepto presente en los vacíos de la respuesta bajo una forma no enunciada, presente en esa respuesta hasta tal punto de producir y de hacer aparecer en ella sus vacíos, como los vacíos de una presencia. Marx restablece la continuidad del enunciado introduciendo-restableciendo en él el concepto de fuerza de trabajo, presente en los vacíos del enunciado de la respuesta de la economía política clásica; y al establecer-restablecer la continuidad de la respuesta mediante la enunciación del concepto de fuerza de trabajo produce, al mismo tiempo, la pregunta hasta entonces no planteada, a la cual responde la respuesta hasta entonces sin pregunta (...) ¿Cuál es el valor de la fuerza de trabajo?

\footnotetext{
${ }^{8}$ Marta Hanecker, la traductora de la edición utilizada traduce bevues por desacierto, creemos que es más acertada traducirla por "inadvertencias".

${ }^{9}$ Con una aguda mirada Bidet (2009) sostiene que antes de llegar a las relaciones de clase, Marx comienza por hacer frente a la pretensión del liberalismo según la cual, en la modernidad, prevalecería una "economía de mercado". Por ello, "propone leer" el parágrafo tercero del capítulo primero, "La forma del valor". También problematiza el hecho de que, de una versión a otra de EC, desaparece esta famosa contradicción entre el valor de uso y el valor a secas- contradicción que no concierne al mercado sino al capital "en la forma determinada entre el valor de uso y plusvalía. Para Bidet, que la "ley de mercado" sea una ficción y en qué sentido, es lo que no puede mostrarse al comienzo.
} 
Para Althusser, dado que "estamos aún muy cerca de Marx como para apreciar verdaderamente la carga de la revolución científica que provocó (...) el retraso de la filosofía en relación con la ciencia es inevitable, pero además debe ser remontado" $(\mathrm{QH}$ : 3). La revolución teórica es entonces -según Althusser- doble; ya que implica una ruptura en la ciencia, y en la filosofía.

Efectivamente, la revolución científica de Marx -señala Althusser- contiene una revolución filosófica que, forzando a la filosofía a pensar su relación con la historia, revoluciona a la economía. Esta nueva ciencia, este nuevo problema científico, se ha denominado materialismo histórico: "ciencia de la Historia"; que para Althusser es algo más que un descubrimiento "simplemente científico", ya que involucra importantes consecuencias filosóficas:

Marx funda una ciencia nueva, es decir, elabora un sistema de conceptos científicos nuevos, allí donde antes sólo reinaba la disposición de nociones ideológicas. Marx funda la ciencia de la historia, allí donde sólo existían filosofías de la historia. Cuando afirmamos que Marx dispone de un sistema teórico de conceptos científicos en el ámbito donde reinaban antes filosofías de la historia, tejemos una metáfora que sólo es una metáfora: pues sugerimos que, en un mismo espacio, el de la Historia, Marx reemplazó teorías ideológicas por una teoría científica. (L y F: 31)

La fundación de esta "nueva ciencia", la ciencia de la historia, el materialismo histórico por parte de Marx, se ve posibilitado según Althusser, por un cambio de problemática que produce una ruptura en el pensamiento de $\operatorname{Marx}^{10}$.

El cambio de problemática implica nuevas problemáticas y nuevos instrumentos de pensamiento ya que "no es la materia de reflexión lo que caracteriza y califica la reflexión, sino la modalidad de la reflexión, la relación efectiva que la reflexión mantiene con sus objetos, es decir, la problemática fundamental a partir de la cual son pensados los objetos de este pensamiento. Pero, ¿qué es una problemática y cómo se

\footnotetext{
${ }^{10}$ Si para Althusser existe una ruptura en el pensamiento de Marx, para otros autores como Lukács (1970) existe un cambio progresivo y evolutivo en la obra marxista, con lo cual el desarrollo de su pensamiento sería de continuidad y de superación (Aufhebung). También existen diferencias entre quienes reconocen la ruptura en relación con el periodo o momento de la transformación teórica de la obra de Marx; diferencias en torno a la naturaleza de esa transformación, y a la obra u obras decisivas en ellas.
} 
establecen los cambios de esta? Indagaremos esta cuestión en el próximo apartado.

\section{El cambio de problemática}

...antes de Marx únicamente dos grandes continentes habian sido abiertos al continente cientifico por cortes epistemológicos continuados: el continente Matemáticas con los griegos (...) y el continente Física (...). Marx abrió al conocimiento científico un nuevo y tercer continente científico, el continente Historia...

(Althusser, Lenin y la filosofía)

La ruptura teórica de Marx, en el marco de la lectura de Althusser, implica una nueva problemática, esto es, un terreno nuevo sobre el que son abordados los problemas planteados, así como nuevos instrumentos. Para Althusser, Marx funda sobre un elemento nuevo su pensamiento teórico, como los atenienses que fundan después de la guerra contra los persas, la ciudad sobre el mar.

El concepto de problemática entonces, un concepto específico de la teoría althusseriana, tiene un gran valor heurístico -como señala De Ipola (2007) y es fundamental y transversal en la intervención materialista de Althusser, siendo expuesta por primera vez en Contradicción y sobredeterminación de la siguiente manera:

Decir...que una ideología constituye una totalidad (orgánica) es válido sólo a título de descripción, y no a título de teoría, nos expone a no pensar sino en la unidad vacía de un todo descrito, y no una estructura determinada de unidad. Pensar, por el contrario, la unidad de un pensamiento ideológicamente determinado (que se da de inmediato como un todo, y que es

"vivido" implícita o explícitamente como un todo, o una intención de "totalización") con el concepto de problemática es permitir la puesta en evidencia de la estructura sistemática típica, que unifica todos los elementos de un pensamiento; es por lo tanto, descubrir un contenido determinado a esta unidad, que permite, a la vez, poner en relación a esta ideología con los problemas legados o planteados a todo pensador por el tiempo histórico en que vive.

(RTM: 53).

Cuando Althusser señala que la existencia práctica de la filosofía marxista (la contenida en El capital y en la práctica económica y política del movimiento obrero) había que darle una existencia teórica, está haciendo referencia a hacer una elucidación crítica, una lectura sintomática de las obras de Marx y del marxismo. Es decir, la 
producción de la problemática ${ }^{11}$ más profunda que permitiría ver aquello que aún no podía tener más que una existencia alusiva o práctica como materia prima de la elaboración de la ciencia teórica.

Por ello es que Althusser propone "hacer manifiesto lo que está latente, pero esto quiere decir transformar aquello que en cierto sentido existe ya" (PLC: 40). En otras palabras, de lo que se trata es de producir, en el sentido estricto de la palabra "respuestas a preguntas que estos textos no aciertan a formular porque producen enunciados que rompen el molde de la problemática en la que han sido producidos" (Karczmarczyk, 2016b: 274). En esta dirección, Althusser realiza una lectura doble de los análisis práctico- políticos de Lenin y puede plantear una pregunta no formulada: “¿cuál es la diferencia específica entre la dialéctica hegeliana y la dialéctica marxista?"12. La ausencia de esta pregunta -señala Althusser- cuya respuesta es la “inversión" indica un problema real ausente: "la ausencia del concepto tras la palabra" (PLC: 38).

Lo que pretende mostrar Althusser, a partir de esta ausencia es que, la dialéctica marxista no es simplemente una inversión de la dialéctica hegeliana; la que no tenía como punto de partida el conocimiento como un "concreto real" puesto que al identificar sujeto/objeto, concebía que la totalidad era engendrada por el pensamiento. Sino que se trata de un método de análisis original que parte de lo abstracto a lo concreto ("un "método teórico en el que es necesario que el sujeto, la sociedad, esté presente en la representación como premisa" (I: 22)). Este método materialista original del materialismo dialéctico, según Althusser, se habría estado anunciando a partir de 1845 con La ideología alemana donde Marx y Engels pondrían la dialéctica sobre bases materialistas, partiendo de las intuiciones y representaciones de "lo real concreto" (LIA: 25-26).

En esta dirección, Althusser afirma que, desde una lectura "ingenua" (por decir, teleológica y lineal) Marx simplemente habría invertido la dialéctica hegeliana. Incluso, es el propio Marx el que señala que la especificidad de su método radicaría en una inversión del método hegeliano, como muestra la siguiente cita de El capital:

\footnotetext{
${ }^{11}$ El concepto de problemática pone en evidencia la estructura sistemática típica, que unifica todos los elementos de un pensamiento" (RTM: 53). Encontrar el contenido determinado de esta unidad, permitiría concebir el sentido de los elementos de la ideología considerada, y "poner en relación esta ideología con los problemas legados o planteados a todo pensador por el tiempo histórico en que vive" (Ídem).

${ }^{12}$ Unos años más tarde, en Lenin y la filosofía, Althusser se preguntará: ¿Cuáles son las relaciones entre el materialismo y la dialéctica en el materialismo dialéctico? ¿qué es la dialéctica, un simple método o la filosofía entera?" (L y F: 25).
} 
Mi método dialéctico no sólo difiere del de Hegel, en cuanto a sus fundamentos, sino que es su antítesis directa. Para Hegel el proceso del pensar, al que convierte incluso, bajo el nombre de idea, en un sujeto autónomo, es el demiurgo de lo real; lo real no es más que su manifestación externa. Para mí, a la inversa, lo ideal no es sino lo material traspuesto y traducido en la mente humana. (EC, I, I, vol.1, p. 19)

Desde una lectura inmediata entonces, en Marx simplemente habría "inversión" de los términos del modelo hegeliano, constituido por la sociedad civil y el Estado; sustituyéndolos por la estructura (la base económica: fuerzas productivas, relaciones de producción) y la superestructura (el Estado y todas las formas jurídicas, políticas e ideológicas). Sin embargo, haciendo una lectura doble, Althusser detecta que el método dialéctico que se encuentra en las obras de madurez de Marx es completamente original, en la medida que involucra una dialéctica -no "pura y simple" como en Hegel, subsidiaria de una concepción de totalidad orgánica cuyo principio interno simple la llevaría a ser lo que está destinada ser (teleología)- sino sobredeterminada.

La existencia de esta contradicción sobredterminada de la dialéctica marxista, constituye uno de los cimientos centrales de Althusser, para argumentar "la revolución" de la filosofía de Marx. La que "produce" un cambio en los términos mismos, teniendo como piedra de toque a la filosofía de Hegel, de la que se demarca. Tal como señala Althusser en su Defensa de Tesis en la Universidad de Amiens:

En la Introducción de 1857 Marx decía: lo concreto es la síntesis de múltiples determinaciones de las relaciones en las cuales están prisioneros y participantes. Si Marx no parte entonces del hombre que es una idea vacía, es decir sobrecargada de ideología burguesa es para llegar a los hombres concretos, si pasa por el rodeo de esas relaciones cuyos "portadores" son los hombres concretos es para llegar al conocimiento de las leyes que ordenan tanto su vida como sus luchas concretas.

(SM: 245- 246)

Marx funda, según la lectura althusseriana, una ciencia cuyo objeto es completamente diferente del de sus predecesores, pero que no se puede dimensionar porque Marx no formula los conceptos de su teoría. Esa limitación se debe -según Althusser- a que Marx no tendría un lenguaje todavía, para hablar del objeto de su 
ciencia y, entonces, habla de él en lenguaje hegeliano, que es el que tenía disponible en ese momento.

Frente a la ausencia de los conceptos centrales de la teoría marxista, Althusser se propone darles consistencia, y es así que conceptualiza la causalidad estructural, la autonomía relativa, el todo complejo estructura con dominante, la contradicción sobredeterminada, entre otros.

\section{Ruptura epistemológica con la problemática ideológica}

La oposición entre la ciencia y la ideología, y la noción de ruptura epistemológica que sirve para pensar el carácter histórico de esta oposición, supone pensar una tesis que, a pesar de estar siempre presente detrás de estos análisis, no ha sido, sin embargo, desarrollada explícitamente: la tesis de que el descubrimiento de Marx es un descubrimiento cientifico sin precedentes en la historia. (Althusser, Maquiavelo y nosotros)

De acuerdo con la lectura althusseriana, a partir de 1845 Marx habría efectuado una ruptura epistemológica- que Althusser dice tomar de Gastón Bachelard ${ }^{13}$ - y la rebautiza corte epistemológico para designar "el acontecimiento teórico" que inaugura el nacimiento de una ciencia: la ciencia marxista de la Historia.

Según Althusser, en el pensamiento de Marx, se produce un corte irreversible y continuado con la problemática ideológica anterior, en la que subyacían -de acuerdo a la mirada althusseriana- ciertos supuestos propios de un abordaje filosófico idealista, entre los que se destacaba el suponer a un sujeto constituyente de la realidad, y el suponer un Origen y un Fin ya determinados en la Historia. Pero Marx, según Althusser, desde 1845 habría comenzado a romper "con su conciencia filosófica anterior", inscribiendo a la ideología en un nuevo terreno, el de las contradicciones de la sociedad dividida en clases. Lo que le habría permitido mostrar la relatividad histórica de la sociedad burguesa y, por lo tanto, la articulación de la ideología con la división del trabajo dando cuenta del estatuto del Estado y de la política con las formas de conciencia.

Efectivamente, la ruptura epistemológica comenzaría en el pensamiento de Marx a partir de la inscripción de la ideología en la base material, profundamente

\footnotetext{
13 Aunque se trate de un falso reconocimiento según Balibar (2004) ya que el concepto no aparecería explícitamente en las teorizaciones de Bachelard, sino que habría únicamente alusiones a la ruptura bajo expresiones como escisión, separación clara, entre otras.
} 
imbricada con las otras instancias de la estructura social en la que esta tiene un estatuto central, puesto que es a partir de ella que "los hombres toman conciencia de su lugar en el mundo y en la Historia" (LIA: 45). Y en la que los "hombres" dejan de ser pensados como constituyentes y fundantes, para pasar a ser considerados como un efecto de la estructura social, en la que ocuparán los lugares que les serán asignados previamente y que serán garantizados mediante mecanismos ideológicos. De manera que la ideología pasa a tener la función social de legitimar determinadas prácticas para garantizar la reproducción de las relaciones sociales capitalistas.

Esta inscripción de la ideología en la vida material concreta de los sujetos, se manifiesta centralmente en que esta aparece profundamente vinculada a las condiciones materiales de existencia que garantizan la reproducción de la ideología ("no es la conciencia la que determina la vida, sino la vida la que determina la conciencia" (LIA: 26).Sin embargo, habría aun resabios mecanicistas (de determinación automática por la base estructural hacia las instancias superestructurales en la que se encontraría la ideología, la filosofía, etc.) y positivistas ("una concepción no marxista de la Ideología") ya que allí la ideología es presentada como mera ilusión: "toda su realidad está fuera de ella misma" (SR: 213). Por esa razón, según Althusser, en La ideología alemana hay referencias a la conciencia, a las representaciones de un sujeto- centro, y "alienado" por las condiciones de existencia, es decir, al subjetivismo, la interioridad y la idealidad; pero vinculadas a las condiciones concretas de vida de los "hombres".

A propósito de los tratamientos idealistas de la ideología, cabe señalar que, desde Bacon pasando por De Tracy, Napoleón e incluso Feuerbach, "la ideología" (también bajo el nombre de ídolo, prejuicio, o religión) era considerada una distorsión psicológica desvinculada del desarrollo histórico de las relaciones sociales de los seres humanos. Estas distorsiones ideológicas eran explicadas en términos de pasiones, supersticiones, intereses individuales, prejuicios religiosos; pero nunca conectadas a contradicciones sociales históricamente necesarias.

Sin embargo, Althusser propone atender a tesis de La ideología alemana que dan cuenta de la inscripción de esta obra en una problemática materialista, como cuando Marx y Engels afirman que "no es la conciencia la que determina la vida, sino la vida la que determina la conciencia" (Ibíd.: 26) que se opone precisamente a la filosofía especulativa de los jóvenes hegelianos. Para Althusser, una tesis como la anterior, manifiesta una determinación en última instancia por la infraestructura económica, que se basa en una concepción dialéctica materialista, totalmente distinta a la hegeliana que 
considera que la totalidad social es engendrada por el pensamiento. En contraposición, Marx y Engels pondrían la dialéctica sobre bases materialistas, partiendo de las intuiciones y representaciones de "lo real concreto" (LIA: 25-26).

Aunque, por otra parte, si se examina la distinción entre conciencia y naturaleza que Marx y Engels efectúan al plantear la distinción entre trabajo manual y trabajo intelectual -el que permitiría a la conciencia "pasar a la formación de la teoría pura, de la teleología, la filosofía, la moral, etc.” (Ibíd.: 32)- se advierte que la teoría de Marx con el idealismo no fue total. Sino que da cuenta de que La ideología alemana es un texto de ruptura que contiene elementos contradictorios. Por ello es que, si bien la ideología aparece fuertemente vinculada con la base material, también existen resabios idealistas, dado que "lo superestructural" se considera como "quimeras idealistas" (Ibíd.: 40); "reflejos invertidos" (Ibíd.: 26) donde se incluye a la moral, la religión, las leyes, la política (Ibíd.: 35); y al Estado (Ibíd.: 38$)^{14}$. Con lo cual se configura una clara oposición entre ideología y práctica, en la que los elementos de la sociedad "se desvanecen en la práctica productiva de los hombres" (Ídem).

Althusser no deja de reconocer el obstáculo que significa que, en este texto de 1845, la ideología se encuentre caracterizada como "falsa conciencia", aunque esta conciencia falseada lo sea de la realidad material, considerada un "todo complejo estructurado" 15 de la que la ideología formaría parte orgánica. Este desliz idealista se vincula según Althusser, al hecho de que la ruptura de Marx con la problemática ideológica anterior se realiza sobre un "material" contradictorio, que se manifiesta también en las representaciones de un sujeto- centro, y "alienado" por las condiciones de existencia. Mientras que en El capital Marx rompe con esa problemática humanista y afirma que "no es el fantasma de la esencia o de la naturaleza humana, no es el hombre ni incluso los hombres, sino una relación, la relación de producción, que conforma la base, la infraestructura" (PLC: 179).

No obstante, Althusser reconoce que existe una tensión en el planteo de Marx que compromete a la ideología con un supuesto representacionalista. En este sentido,

\footnotetext{
14 Antonio Gramsci (1975) rechaza el esquema rígido de la concepción clásica de la ideología perteneciente al marxismo ortodoxo en la que la superestructura- es una representación determinada mecánicamente por la estructura material. Y formula la definición de bloque histórico donde las fuerzas materiales son el contenido y las ideologías la forma, operando un importante cambio respecto a la concepción mecanicista tradicional.

${ }^{15}$ Es significativo también que Macherey haya advertido a Althusser el problema en el que incurre al formular que la realidad social es un todo orgánico. Para Macherey, "la idea de un todo es realmente la concepción espiritualista de estructura" (Montag, 2013: 74. La traducción es nuestra).
} 
Althusser señala que, en La ideología alemana, hay un "idealismo abierto o latente de una filosofía de la historia", de un Origen y de un Fin, de un Sentido de la historia, encarnada en la sucesión de las "épocas progresivas" de modos de producción determinados conducentes a la transparencia del comunismo. En otras palabras: habría todavía en Marx, la idea latente de una transparencia total de las relaciones sociales en el comunismo, la idea de que estas relaciones sociales son "relaciones humanas", relaciones claras entre simples individuos en la conquista y la realización del "libre desarrollo de su personalidad" (MDL: 54) ${ }^{16}$.

Un idealismo que se manifiesta también según Althusser, en que Marx "entiende el Estado como simple traducción mecánica de la correlación de fuerzas en la infraestructura y olvida el carácter esencialmente actuante y articulador (en las relaciones sociales y en la conciencia de sus agentes) de la ideología” (Ibíd.: 11). Lo cual, según Althusser, remite, por un lado, a una teoría de la superestructura en la que figuran el Estado y las Ideologías. Y por otro, remite a una teoría de las condiciones materiales (producción), sociales (división del trabajo, lucha de clases), ideológicas y filosóficas del proceso de producción de los conocimientos. Es decir, a una ciencia de las formaciones sociales, "sin precedentes" en la que la ideología comenzaría a tener un contenido científico, ya que, a partir de esta ruptura, las ideologías ya no son meras ilusiones "sino cuerpos de representaciones existentes en instituciones y prácticas: figuran en la superestructura y están fundadas en la lucha de clases" (EA: 78).

Ahora bien, el corte epistemológico que Althusser ve en el pensamiento de Marx, implica una demarcación de la filosofía materialista con la problemática ideológica, que fue criticada por restituir una forma de positivismo al plantear una única ruptura que "opone la verdad al error” (Ibíd.: 12). Además, esta ruptura tendría una

\footnotetext{
16 Según Althusser el idealismo también asedia a la Contribución de 1859 ya que los modos de producción allí son alineados en una lista continua y en una sucesión obligada de crecimiento progresivo: la serie ordenada de comunismo primitivo, esclavismo, servidumbre, capitalismo y comunismo. Así, ninguna sociedad podía "coger el tren en marcha" sino que cada una debía recorrer toda la serie. El mismo idealismo, asedia, según Althusser, a El capital, donde el orden de exposición tenía una unidad ficticia. "Pero ¿por qué esta unidad ficticia? Porque Marx se veía obligado como buen 'semihegeliano', es decir, como hegeliano "invertido" en materialista que era, a afrontar en una disciplina de carácter científico la cuestión puramente filosófica del comienzo de una obra filosófica" (MDL: 55). No es casual, señala Althusser, que Marx haya tenido que escribir y reescribir numerosas veces el capítulo I de $E l$ capital, y haya tenido que comenzar por la abstracción del valor "lo que ha dado una fuerza impresionante a sus demostraciones, pero, al mismo tiempo, las ha 'encuadrado' en un campo teórico muy incómodo cuando se trata de 'deducir' la moneda, la explotación capitalista y todo lo demás” (Ibíd.: $56)$.
} 
tendencia teoricista, que es reconocida por el propio Althusser y lo conduce a rectificar su posición en lo que se conoce como sus textos de autocrítica.

La rectificación no implica, sin embargo, que desaparezca la relación entre ciencia e ideología, sino que pasa a estar atravesada por la distinción entre ideologías teóricas e ideologías prácticas que se configura a partir de la segunda edición de $L a$ Revolución teórica de Marx. A partir de ahora, no cualquier actividad del pensamiento es pura abstracción, sino que se distingue las teorías y prácticas teóricas; de las prácticas sociales y formaciones sociales, de las que destaca su modo fundamental de supervivencia. En esta línea: mientras que las ideologías teóricas son aquellos discursos con pretensiones de cientificidad a los cuales las ciencias pueden denominar precientífico; las ideologías prácticas son formaciones complejas constituidas por nociones- representaciones- imágenes, de un lado; y por comportamientos- conductas, actitudes, de otro.

En efecto, Althusser hace autocrítica de su teoricismo y propone comprender a la práctica filosófica como una intervención materialista en un campo de batalla (Kampfplatz) en la que se demarca del idealismo. Puesto que, una filosofía de tendencia materialista reconoce la existencia de la realidad objetiva exterior, así como su independencia respecto del sujeto que la percibe. Reconoce que el ser, lo real, existe y es anterior a su descubrimiento, a su ser pensado o conocido. Es dentro de estas coordenadas que para Althusser -en su lectura de Marx- "la filosofía no es un delirio teórico ni un fantasma individual, ni un mero sueño o falsa conciencia. No es tampoco meramente abstracción, sino que tiene una eficacia propia dentro del entramado de la estructura social. Se trata de una filosofía que no se pretende autónoma, ni fundadora de su propio origen y del lugar que ocupa; tampoco tendría la pretensión de ser una Ciencia de las Ciencias, como lo pretende el positivismo.

Entonces bien, a partir de su posición rectificada, Althusser señala que la ruptura que él ve en el pensamiento de Marx, no es una ruptura entre la ciencia en general y la ideología en general; sino que se trata específicamente de la ruptura de la ciencia marxista con su prehistoria teórica, que remite a algo distinto de una teoría de la diferencia entre la ciencia y la ideología, a algo distinto de una epistemología. Esta distinción entre ideología en general e ideologías particulares, se vincula fuertemente a una segunda ruptura: con las interpretaciones idealistas de la historia, como el historicismo, que precipitaría a la teoría de la historia en la historia real, "y reduce el objeto (teórico) de la ciencia de la historia, a la historia real" (PLC: 145). Dado que a 
partir del corte la ideología deberá ser pensada como la "prehistoria de la ciencia", como una historia real que posee sus leyes propias, como la condición de posibilidad de advenimiento de una ciencia.

Ahora bien, para Althusser existe un malentendido en la interpretación historicista de la famosa frase de la Tesis XI de Feuerbach "Los filósofos no han hecho más que interpretar los diversos modos del mundo, pero de lo que se trata es de transformarlo" (Cfr., RTM: 61). Esta tesis, según Althusser, invitaba a la transformación del mundo, no a su interpretación. Sin embargo, Labriola, Lukács y Gramsci la reinterpretan -e incluso les permite "fijar el nacimiento de la filosofía marxista" (Roies, 1974: 17)- lo que los lleva a definir el marxismo como "una filosofía de la praxis" (Ídem).

Pero según lo ve Althusser, esta frase no generó ninguna filosofía nueva, sino que, por el contrario, "sólo abrió un largo silencio filosófico" (L y F: 28) que duró más de 30 años. Lo que anuncia la Tesis, dice Althusser, es el lenguaje necesariamente filosófico de una declaración de ruptura con toda filosofía "interpretativa". Algo muy distinto a una "filosofía nueva" (Ibíd.: 30). Es por ello que para Althusser, la Tesis XI de Marx, quizás se adelantó cuando "anunciaba efectivamente un acontecimiento mayor en la filosofía" (Ibíd.: 37- 38). Quizás: "los tiempos no estaban maduros, que no había caído la noche, y que ni el mismo Marx, ni Engels, ni Lenin podían todavía escribir esa gran obra filosófica de la que carece el marxismo" (Ibíd.: 40).

Este retraso de la filosofía en relación a la ciencia - que "es inevitable, pero además debe ser remontado" (QH: 3)- consiste en que esta última se hallaba adelantada respecto de las categorías filosóficas de su coyuntura. Y constituye una explicación de por qué los descubrimientos científicos no son comprendidos inmediatamente por sus contemporáneos. Por ello es que para Althusser es necesario considerar que, "estamos aún muy cerca de Marx como para apreciar verdaderamente la carga de la revolución científica que provocó (...) que implica una ruptura en la ciencia, y en la filosofía.

Efectivamente, la revolución científica de Marx -señala Althusser- contiene una revolución filosófica que, forzando a la filosofía a pensar su relación con la historia, revoluciona a la economía. Esta nueva ciencia, este nuevo problema científico, es el materialismo histórico -"ciencia de la Historia"- que ha revolucionado la problemática anterior. Ya que se produce un corte radical en la filosofía de Marx entre los conceptos iniciales de ese materialismo histórico (modo de producción, lucha de clases, ideología, etc.) y la problemática de la ideología jurídica, económica y moral anterior, a la que 
pertenece el humanismo teórico de la alienación. Para Althusser, esto implica, además, importantes consecuencias filosóficas, como da cuenta la siguiente cita:

Marx funda una ciencia nueva, es decir, elabora un sistema de conceptos científicos nuevos, allí donde antes sólo reinaba la disposición de nociones ideológicas. Marx funda la ciencia de la historia, allí donde sólo existían filosofías de la historia. Cuando afirmamos que Marx dispone de un sistema teórico de conceptos científicos en el ámbito donde reinaban antes filosofías de la historia, tejemos una metáfora que sólo es una metáfora: pues sugerimos que, en un mismo espacio, el de la Historia, Marx reemplazó teorías ideológicas por una teoría científica. (L y F: 31)

Cabe señalar a propósito del terreno de la historia, que en este periodo de autocrítica Althusser va a proponer que la historia sea pensada sin sujeto ni fines, lo que constituye un corte epistemológico con el tratamiento idealista de la historia. Pero este corte, desde entonces es pensado como un proceso continuado y no un resultado definitivamente acabado en un instante es "un comienzo que no tendrá fin" (Ly F: 33). Se trata de un proceso de constitución y desarrollo de una teoría científica. Porque además "la historia de la razón no es ni una historia lineal de desarrollo continuo, ni es en su continuidad la historia de la manifestación o de la toma de conciencia progresiva de una Razón” (PLC: 73).

En este sentido, Althusser avanza y sostiene que, si la ciencia marxista muestra como ideológicas las concepciones teóricas inscritas en su propia prehistoria, no es sólo para denunciarlas como falsas, sino también para mostrar que se aceptaban como verdaderas "porque eran los destacamentos teóricos de ideologías prácticas que asumían las funciones necesarias en la reproducción de las relaciones de producción de una determinada sociedad de clase" (EA: 78).Desde esta perspectiva, las relaciones sociales ya no pueden ser pensadas como relaciones simplemente humanas, sino que son relaciones entre agentes de la producción, es decir, entre individuos que tienen una función bien determinada en la producción de bienes materiales. Este reemplazo del término "hombre" por el de "agente de producción", manifiesta según Althusser, que la ruptura de Marx era de una envergadura absolutamente diferente. Puesto que se efectuaba no solamente con respecto a las concepciones ideológicas de la historia existentes, sino también con las ideologías prácticas y teóricas, en la filosofía y hasta en 
las obras de la economía política y del socialismo utópico.

Ahora bien, nos resulta fundamental retornar a una cuestión primaria: ¿de dónde proviene en términos filosóficos, la concepción de ruptura que Althusser encuentra en el pensamiento de Marx? Para Althusser, "si se quiere encontrar un antepasado filosófico a Marx, en este punto, más que a Hegel, es necesario dirigirse a Spinoza" (UTM: 135) ${ }^{17}$ para quien la ideología no es concebida como puro error, ilusión o sueño. Sino que se trata de una instancia de la vida material y concreta de los hombres, tal como ellos la viven (lo que Spinoza llama el Primer Género de Conocimiento: algo diferente de un "conocimiento" $" 18$, circunstancias históricas de la que los hombres no son "dueños", ni fundadores.

En efecto, este antepasado filosófico es Spinoza -según Althusser- quien se anticipaba a Hegel, e iba más lejos: ya que este último no regateó un lugar al Sujeto, no sólo en el "devenir-Sujeto de la Substancia" (por lo que "reprocha" a Spinoza el "error" de permanecer en la Substancia), sino en la interioridad del Telos del proceso sin Sujeto que realiza los designios de la Idea en virtud de la negación. De esta forma Spinoza nos

\footnotetext{
${ }^{17}$ Nicolás González Varela (2010) ha realizado un valioso trabajo que presenta la lectura que Marx hace de Spinoza en los Cuaderno Spinoza mostrando similitudes entre ellos: ambos han sido desterrados, considerados "malditos" y ambos han realizado aportes fundamentales a la tradición materialistasepultada durante un largo periodo. Bajo la impresión de Matheron, del Tractatus theologico- politicus "nace una obra de Marx escrita con el estilo de Spinoza" (Varela, 2010: 115). Mientras que, André Tosel (2016) señala que la novedad de la lectura althusseriana, tiene un doble movimiento sobre el que reside su novedad: de Spinoza a Marx, y de Marx a Spinoza. El primer movimiento que lo conduce de Spinoza a Marx, le permite comprender retrospectivamente las virtualidades del punto de partida en el Tratado teológico político, ya que en este marco Marx es comprendido como "un continuador de Spinoza: crítico de las autoridades económico- político- teológicas, y al mismo tiempo, como un pensador epocal de la emancipación, el político de una nueva práctica de la filosofía: inmanentista, antimetafísica y materialista de nuevo tipo" (p. 4). Marx continuaba a Spinoza según esta lectura, al inaugurar un nuevo continente: el continente- historia abierto a partir de la crítica teológica-económica- política que realiza Marx. El segundo movimiento, es el que Althusser habría desarrollado desde el principio que principio que consistía en usar ciertos aspectos de la problemática spinoziana para proceder a una crítica de los elementos de una dialéctica idealista todavía presentes en el Marx de El capital. Spinoza operaría así, como una especie de recurso para reformar la teoría y la práctica del movimiento obrero y del marxismo, a partir de 3 elementos: la crítica de la teología del sentido que se establece en torno al mito del origen y del fin; el rechazo dela posición de un Sujeto como condición trascendental de la constitución de lo real sobre el fondo de la dualidad entre cuerpo y espíritu; el rechazo a la creencia de un advenimiento; rechazo a una concepción de la Ciencia como anulación de toda Ideología (Tosel, 2016: 7- 8).

${ }^{18}$ En El porvenir es largo, Althusser señala que había encontrado en el conocimiento del 'primer género' el conocimiento a fortiori no una teoría del conocimiento -teoría de la 'garantía' absoluta de todo saber, teoría 'idealista'-, sino una teoría del mundo inmediatamente vivido (para mí, la teoría del primer género era sencillamente el mundo, es decir la inmediatez de la ideología espontánea del sentido común)" (EPL: 289)
} 
descubre, dice Althusser que, "entre el Sujeto y el Fin, la alianza que "mixtifica" la dialéctica hegeliana" (Ibíd.: 136).

Para Althusser "tanto en la Ética como en el Tratado teológico político, se encuentra sin dudas, la primera teoría de la ideología que jamás haya sido pensada" (SM: 196), la primera crítica del concepto "ideológico de la ideología” (UTM: 135) y que tiene como estrategia filosófica, nada más y nada menos que comenzar por Dios para cercarlo. Realizando así una de las críticas más poderosas contra la religión; y contra la metafísica imperante en su tiempo que colocaba al Sujeto como categoría central de la ilusión imaginaria. Mientras que, para Spinoza, el sujeto- hombre- centro de la naturaleza, era un mito teórico, y propone pensarlo como parte de la naturaleza, sometido a sus leyes.

Este rechazo spinoziano al antropocentrismo es formulado por Althusser en su obra Elementos de autocrítica como antihumanismo filosófico de Spinoza. De allí que la lectura de Marx por Althusser sea también un retorno a la filosofía spinoziana, de ahí la insistente pregunta: “¿por qué remitirse a Spinoza cuando se trataba de ser simplemente marxistas? ¿Por qué este rodeo?” (EA: 45).

\section{El antihumanismo de Spinoza}

Podemos considerar a Spinoza, desde el punto de vista filosófico, como el único antepasado directo de Marx (Althusser, "El objeto de El Capital")

El rechazo a todo esencialismo del sujeto ("el trabajo como esencia del hombre") lleva a Althusser a establecer un paralelismo entre Hegel y Spinoza mostrando que, aunque en los dos casos lo que estaba en juego era una concepción subjetivista trascendental de la "verdad" y del conocimiento,

El paralelismo iba más lejos. Ya no hay "cogito" en Spinoza (sino tan solo la proposición factual "homo cogitat", el hombre piensa) ya no hay sujeto trascendental en Hegel, sino un sujeto como proceso (paso por alto su teleología inmanente). No hay teoría del conocimiento (es decir, garantía a priori de la verdad y de sus efectos científicos, sociales, morales y políticos) en Spinoza; no hay tampoco teoría de garantía de toda verdad, o de todo conocimiento - mientras que por su lado Kant produce una teoría jurídica del conocimiento bajo el "yo pienso" del Sujeto trascendental y las condiciones a priori de toda experiencia posible. En 
ambos casos, Spinoza y Hegel consiguen (...) desembarazar el espíritu de la ilusión de la subjetividad trascendental como garantía o fundamento de todo sentido o de toda experiencia de verdad posible.

Efectivamente, el rechazo de Hegel y de Spinoza a la concepción subjetivista trascendental de la "verdad" y del conocimiento, establece una demarcación de Spinoza contra Descartes y de Hegel contra Kant. En este sentido, si Descartes presenta en la forma de garantía divina una teoría de la garantía de toda verdad o de todo conocimiento, y Kant produce una teoría jurídica del conocimiento bajo el "yo pienso" del Sujeto trascendental y las condiciones a priori de toda experiencia posible; Hegel y Spinoza no postularían una teoría del conocimiento.

En el caso de Spinoza, el hombre es parte de la naturaleza y está sometido a sus leyes, "un imperio dentro de otro imperio". En este marco, Dios es Causa, y el "hombre", efecto, con el que comparte, la misma Substancia. Una Substancia única, formada por infinidad de atributos, realmente distintos; que expresan, sin embargo, la esencia indivisible de una única substancia. En este marco, la realidad "única e infinita" no es tal por subsumir un número infinito de seres, sino por estar constituida por una diversidad absoluta, desde el punto de vista cualitativo.

Ahora bien, Althusser afirma que Marx se hallaba próximo a Hegel por la insistencia de este último en rechazar toda filosofía del Origen y del Sujeto, fuese ella racionalista, empírica o trascendental: por su crítica a la idea de una teoría del conocimiento. También se hallaba próximo a Hegel por la crítica de este último al sujeto jurídico y al contrato social, por su crítica del sujeto moral y de toda ideología filosófica del Sujeto, que "cualesquiera que sean sus variaciones, daba a la filosofía burguesa clásica el medio de garantizar sus conocimientos, sus prácticas y sus fines, no reproduciéndolos simplemente, sino elaborando filosóficamente a partir de los mismos las nociones de la ideología jurídica dominante” (SM: 225).

Pero esta crítica de Hegel, según la perspectiva althusseriana, ya se encontraría en Spinoza, quien al postular "Habemus enim ideam veram" afirma que, porque (enim) detentamos (habemus) una idea verdadera, podemos saber que es verdadera. Según Althusser, con la fórmula "verum index suit et falsi", "lo verdadero se indica por sí mismo e indica lo falso", Spinoza deja de lado el idealismo de una teoría del conocimiento, ya que "lo verdadero" "se inicia a sí mismo" -no como Presencia- sino 
como Producto, "en la doble acepción del término "producto" (resultado del trabajo de un proceso que le descubre) como probándose en su producción misma.

En otras palabras, Spinoza, en la lectura de Althusser, dejaba de lado el problema del "criterio de la verdad" (Ibíd.: 232), sea este externo (adecuación del espíritu y de la cosa en la tradición aristotélica), o interno (la evidencia cartesiana). En cualquiera de estos casos el criterio es rechazado, ya que no es más que la figura de un "Juez" que debe autenticar y garantizar la validez de lo Verdadero. Para Spinoza, según Althusser: "la Verdad y la Jurisdicción del Criterio van siempre a la par, puesto que el criterio tiene siempre por función autenticar la Verdad de lo verdadero" (EA: 50).

Luego de este rodeo por el antihumanismo de Spinoza, cabe señalar que para Althusser se trata del antepasado filosófico de Marx, porque también este último rechaza las pretensiones de dar un estatuto teórico a la categoría de "sujeto" de la filosofía idealista, y en última instancia, a la categoría de "hombre", de la ideología humanista, de la que, por el contrario, se demarca.

\section{La ideología humanista y la crisis del marxismo}

En el mundo teatral o más generalmente estético, la ideología no deja nunca, por esencia, de ser el lugar de una discusión y de un combate donde resuena, sorda o brutalmente, el ruido y las sacudidas de las luchas politicas y sociales de la humanidad (...) (Althusser, El 'Piccolo', Bertolazzi y Brecht)

De acuerdo con la perspectiva crítica de Althusser, el humanismo teórico es una ideología que funciona en articulación con el ideal burgués de la libertad humana: "el hombre sujeto libre, el hombre libre sujeto de sus actos y pensamientos es ante todo el hombre libre de poseer, de vender y de comprar, el sujeto de derecho" (SM: 240). Pero desde el antihumanismo teórico de Althusser, la libertad como esencia humana constituye un concepto ideológico que enmascara las condiciones reales de la crisis del marxismo. Se trata de una tesis subsidiaria del descentramiento del sujeto efectuado por la filosofía contemporánea, al cuestionar conceptos que se proclaman fundacionales, como la idea moderna de Sujeto.

Ahora bien, la polémica tesis del antihumanismo teórico ${ }^{19}$ de Marx se presenta

\footnotetext{
${ }^{19}$ En nota al pie Harnecker indica lo siguiente: "Althusser reconoce en "El objeto de El Capital" de Lire le capital, T. II, p. 73, que con todo rigor debería hablar de a-humanismo teórico. Si empleó la "forma negativa" de anti-humanismo, en lugar de la forma privativa de a-humanismo, sólo es para señalar con
} 
por primera vez en 1963 en Marxismo y Humanismo como respuesta al avance de lo que Althusser identifica como ideología teórica: el humanismo que coloca en el centro al individuo- humano y que avanza en una coyuntura ideológica de crisis del marxismo ${ }^{20}$. Crisis que se manifiesta en la escisión del movimiento obrero internacional después de las revoluciones rusa y china, y del cuestionamiento no sólo a la interpretación del marxismo, sino a la teoría marxista misma.

Althusser señala que las prácticas de Stalin, los monstruosos procesos de 1937-8 en la URSS y la de los años 1949-52 en las democracias populares, permanecieron durante mucho tiempo ocultas. Lo que tuvo un costo muy alto, difícil de sanear ni siquiera con las revelaciones de Jrushov sobre las masacres, las deportaciones en masa y los horrores de los campos $^{21}$. Recién se descubrieron en el XX Congreso del PC soviético realizado en 1956, a partir del cual la URSS comienza a tomar distancia de la práctica staliniana, que culminó con la ruptura definitiva del PC de China con el PC de la URSS a partir del XXII Congreso de $1961^{22}$. Como señala Marta Harnecker (1996) estos acontecimientos repercutieron no solo en el ámbito político, sino que también dieron lugar a "reacciones ideológicas" de los intelectuales comunistas que "revisando" ideas del joven Marx posibilitaron -por su relación de fuerzas favorables esto es, ante la falta de horizontes políticos- la penetración de la ideología burguesa: la del humanismo, en el seno del movimiento obrero bajo la apariencia del marxismo.

Efectivamente, si el humanismo teórico intenta rellenar los espacios vacíos en la teoría de Marx, con términos como conciencia, esencia, hombre, entre otras; para Althusser, era preciso ahondar en las razones profundas de la crisis del marxismo y no recubrirlas de interpretaciones ideológicas e "ideas humanistas" acerca del hombre. Puesto que para Althusser, tal como señala en Marxismo y humanismo:

mayor fuerza la ruptura del marxismo en relación con todas las ideologías humanistas "que desde hace cuarenta años no dejan de amenazar al marxismo" (N/T, p. 190).

${ }^{20} \mathrm{El}$ "Marxismo" para Althusser no es sólo la teoría marxista sino también las organizaciones y prácticas sociales que se han inspirado en ellas

${ }^{21}$ Respecto a esta cuestión, la lectura de Claude Lefort (1988) considera que el aspecto determinista y positivista del marxismo ortodoxo ha mantenido a la izquierda paralizada en un reduccionismo economicista, que la ha llevado a identificar únicamente la ideología con la división de clase, no pudiendo explicar las transformaciones de la ideología en las sociedades modernas. Al mismo tiempo que el análisis de Lefort detecta que el esquema empirista en el cual se encontraba entrampado el marxismo ortodoxo fue precisamente la brecha por la cual penetró el proceso de "ideologización" que tuvo como efecto la degeneración dentro del marxismo y el fortalecimiento de la burocracia.

22 Althusser, que a pesar de que el PC de China intentó, bajo la dirección de Mao, terminar con los peores defectos del estalinismo mediante la Revolución Cultural, ese intento fue fallido porque "los marxistas, y así se consideran los comunistas, han sido incapaces de rendir cuentas de su propia historia” (MDL: 21). 
Sólo se puede conocer algo acerca de los hombres a condición de reducir a cenizas el mito filosófico (teórico) del hombre. Todo pensamiento que se reclamase de Marx para restaurar, de una u otra manera, una antropología o un humanismo teóricos, teóricamente sólo sería cenizas. Pero, prácticamente, podría edificar un monumento ideológico premarxista que pesaría sobre la historia real y correría el peligro de conducirla a callejones sin salida.

(RTM: 240)

Recién en 1978 se comienza a hablar públicamente de "crisis del marxismo", una crisis que Althusser provocativamente celebra (“iViva!”) confiando en su capacidad transformadora y regeneradora, puesto que permitía reconocer que detrás de esta había una fuerte crisis teórica que venía de mucho tiempo atrás; y que en los años '30 con el estalinismo, tomó una forma particular al bloquearse toda salida e impidiendo cualquier tipo de investigación. Ha sido, según Althusser, a causa del movimiento de masas -“que acrecienta las contradicciones y termina por sacarlas a la luz, con gran claridad y con total actualidad- que estamos en una situación nueva: la que nos permite decir que ifinalmente la crisis ha estallado! ifinalmente se hace visible para todos!, ifinalmente un trabajo de corrección y de revisión es posible!" (MDL: 22).

Bajo la convicción de que la teoría marxista constituía para el movimiento obrero "un tesoro político, filosófico y científico que la burguesía siempre había logrado recubrir y oscurecer a través de su lucha de clases y de su ideología” (SR: 74). Y en un contexto de crisis del marxismo y de oportunismo de la ideología humanista, una generación de filósofos marxistas -en la que se encuentra Althusser- "se asignó la tarea de renovar la teoría marxista respecto de la interpretación hegeliana clásica y de los residuos positivistas y evolucionistas" (Marí, 1974: 15). Tal renovación del marxismo implicaba, de acuerdo con el diagnóstico althusseriano, desmontar las lecturas humanistas -por entonces hegemónicas- que imposibilitaban ver cuestiones fundamentales de la filosofía marxista, justamente por pertenecer a una problemática ideológica.

De acuerdo con la lectura althusseriana, Marx habría tomado distancia de la ideología alemana que concibe que toda parte tiene la presencia de la Totalidad (así como "Dios está en todas las cosas") a partir de una ruptura con la ideología humanista que le es subsidiaria. Por ello, Althusser rechaza la problemática ideológica del 
humanismo, que no sería "más que un concepto ideológico" (RTM: 184) que coloca al hombre como centro. Pero Althusser señala en "El objeto de El Capital" que,

la pretensión de que hay un sujeto constituyente es tan vana como lo es la presunción de un sujeto de la visión en la producción de lo visible (...) el "sujeto" no juega el papel que él cree sino el que le es asignado por el mecanismo del proceso" (...) los "verdaderos sujetos" no son los hombres- concretos son los distribuidores de los lugares: las relaciones de producción, pero esas relaciones son algo que no se podría pensar desde la categoría de sujeto.

(PLC: 204)

El rechazo a un "sujeto de la visión" se relaciona estrechamente con el rechazo al empirismo (de la que nos ocuparemos más adelante) bajo el cual se supone que el sujeto con una mirada informada puede acceder al conocimiento. Ahora bien, frente a las lecturas humanistas que se realizaron de los textos del Joven Marx, Althusser propone "desenredarse de la dulce rosquilla de los cuentos" (MDL: 15) de la ideología humanista articulada con las clases dominantes- que ocultan la verdadera naturaleza de la crisis con nociones como libertad, igualdad y propiedad- y ocultan la lucha de clases como motor de la historia (sin sujeto ni fines). En este sentido, Althusser destaca el carácter encubridor que el humanismo tiene respecto de la explotación ideológico jurídico- burguesa de la igualdad y la libertad de todos los hombres. Y lo hace forzado por las circunstancias del escenario político de los '60:

Cogidos en las grandes luchas de clase de la historia contemporánea, nos hallábamos comprometidos en los combates del movimiento obrero y queríamos ser marxistas.

Ahora bien, no era fácil ser marxista e identificarse con la teoría marxista vigente, incluso después del XX Congreso [del Partido Comunista], porque el dogmatismo anterior subsistía junto con el contrapunto de las charlatanerías filosóficas 'marxistas' acerca del hombre. Y como tales charlatanerías se apoyaban sobre la letra de las obras de juventud de Marx era necesario volver a Marx para aclarar un poco el pensamiento obnubilado por las pruebas a que lo sometía la historia. No insistiré acerca del carácter político de mi proceder: tuvo la originalidad —que no le han perdonado jamás - de criticar al dogmatismo no desde las posiciones de derecha de la ideología humanista, sino desde las posiciones de izquierda del antihumanismo teórico, del antiempirismo y del antieconomicismo.

(Fernández Liria, 2002: 73) 
Entonces bien, ante la coyuntura ideológico- política de avance de la ideología humanista, Althusser postula la tesis del antihumanismo teórico de Marx (oahumanismo) -una tesis radical y provocadora ${ }^{23}$ - que no puede entenderse cabalmente sin la referencia a 1) el antihumanismo de Spinoza del que nos ocupamos anteriormente; 2) la propuesta de pensar en los extremos de Maquiavelo; 3) la curvatura del bastón de Lenin. Con respecto a Maquiavelo, Althusser reivindica su regla del método "raramente enunciada pero siempre practicada" (SM: 217) de que es preciso pensar en los extremos, esto es, enunciar tesis- límite, ya que para hacer el pensamiento posible se ocupa el lugar de lo imposible:

Militarmente hablando, esta estrategia filosófica revolucionaria casi sólo recuerda a la teoría de la guerrilla urbana y el cerco de las ciudades por el campo, querida por Mao, o a ciertas formas de estrategia político- militar de Maquiavelo (su teoría de las fortalezas en particular). Yo estaba fascinado por esta audacia sin parangón, que me entregaba algo así como la idea de la esencia extrema de toda estrategia filosófica, su esencia- límite declarada, la que nunca podría sobrepasarse. Así, me recordaba el pensamiento de Maquiavelo que piensa siempre "en los extremos", en los "límites". Y, sin duda, esta estrategia me confortaba en mi estrategia filosófica y política personal: cercar el Partido desde el interior de sus propias posiciones... ¡Menuda pretensión!

En esta dirección se ubica también la propuesta de curvar el bastón de Lenin que Althusser toma como referencia para situaciones en las que "se ha curvado en el sentido no deseado" por lo cual es necesario, curvarlo hacia el otro extremo, efectuando una contracurvatura duradera. En palabras de Althusser en su Defensa de Tesis en Amiens...:

... Se sabe que algunos años después del ¿Qué Hacer? y para responder a las críticas sobre sus fórmulas, Lenin contestaba con la teoría de la curvatura del bastón. Cuando un bastón está curvado en el mal sentido, decía Lenin, para enderezarlo, es decir para que vuelva y se mantenga en la rectitud, es necesario primero curvarlo en sentido opuesto, por lo tanto, infringirle a fuerza de puño una contracurvatura durable. Esta simple fórmula contiene, me parece, toda una teoría de la eficacia de lo verdadero profundamente anclada en la práctica

\footnotetext{
${ }^{23}$ Siendo que la provocación tiene, para el autor, "un alto valor filosófico" (F y M: 79). Y puesto que "todos los filósofos son, en tanto que filósofos, radicales y provocadores" (SM: 219).
} 
marxista. Contrariamente a toda tradición racionalista, que sólo tiene necesidad de una idea recta para rectificar una idea curva, el marxismo considera que las ideas sólo tienen existencia histórica si son tomadas e incorporadas en la materialidad de las relaciones sociales. Detrás de las relaciones entre las simples ideas, hay pues relaciones de fuerza que hacen que ciertas ideas estén en el poder (es lo que se llama, rápidamente, la ideología dominante) y que otras ideas les estén sometidas (es lo que se llama ideología dominada) hasta que cambie la relación de fuerza.

(SM: 217- 218)

Para Althusser, esta estrategia de Lenin es decididamente materialista puesto que "contrariamente a toda la tradición racionalista, que únicamente tiene necesidad de una idea derecha para rectificar una idea curvada, el marxismo considera que las ideas sólo tienen existencia histórica si son tomadas e incorporadas en la materialidad de las relaciones sociales" (Ibíd.: 218) ${ }^{24}$. De allí el rechazo a la ideología humanista, que bajo un discurso esencialista de libertad ("el hombre sujeto libre, el hombre libre sujeto de sus actos y de sus pensamientos, es ante todo el hombre libre de poseer, de vender, de comprar, el sujeto de derecho" (Ídem)); enmascara el fuerte vínculo que la enlaza con las clases dominantes, más precisamente con la burguesía en ascenso, que tenía las exigencias de una economía mercantil y capitalista.

En la entrevista que Althusser le concede a Fernanda Navarro en 1984 publicada en 2005 bajo el título: Filosofía y Marxismo Althusser señala que la gran tradición humanista tuvo el mérito histórico de haber dado al hombre una dignidad: "Los grandes humanistas burgueses que proclamaron que es el hombre el que hace la historia, estaban luchando desde el punto de vista burgués, entonces revolucionario, contra la tesis religiosa de la ideología feudal" (F y M: 79). Sin embargo, para Althusser, "es el capitalismo el que reduce al hombre a un soporte anónimo, intercambiable, apéndice de la máquina. Es la relación de producción capitalista la que trata y sitúa así al hombre, no el teórico de Marx" (Ibíd.: 82. Cursiva del original). De allí el rechazo althusseriano a las lecturas humanistas de la obra de Marx que se basan en considerar la esencia del hombre como fundamento teórico, lo que implica también el rechazo de las categorías filosóficas del sujeto: como esencia, conciencia, etc. de todos los campos en que reinaban,

\footnotetext{
${ }^{24}$ En nota al pie " $r$ " se afirma: "que las ideas únicamente se mantienen o penetran en las masas en función de las relaciones sociales, económicas, políticas e ideológicas que les dan fuerza de existencia y evidencia sociales" (SM: 218).
} 
No sólo de la economía política (rechaza el mito del homo economicus, es decir, del individuo que tiene facultades y necesidades definidas en tanto que sujeto de la economía clásica); no sólo de la historia (rechaza el atomismo social y el idealismo político- ético); no sólo de la moral (rechaza la idea moral kantiana); pero también de la filosofía misma; ya que el materialismo de Marx excluye el empirismo del sujeto (y su reverso: el sujeto trascendental) y el idealismo del concepto (y su reverso: el empirismo del concepto).

La tesis del antihumanismo teórico es una tesis que también tiene como piedra de toque a la filosofía de Feuerbach, en la que el Hombre - la esencia humana- es el centro de su mundo: "no hay nada en su mundo que no sea él porque todos los objetos de su mundo son sus objetos únicamente en la medida en que son la realización y la proyección de su esencia. (...) todos sus objetos son esenciales en la medida en que lo que ellos le dan es siempre tan sólo su propia esencia" (SM: 239).

De acuerdo con la lectura althusseriana, Feuerbach plantea que mediante el mecanismo de la objetivación y de la inversión, la esencia genérica del hombre se da bajo la forma de un objeto exterior, de otro mundo, en la religión. El Sujeto absoluto que es el hombre encuentra así el absoluto en Dios, pero no sabe que lo que encuentra es él. Así, el Sujeto se ve dominado por él mismo, bajo la forma de un Objeto, dios o el Estado, que no es, sin embargo, sino él.

En esa dirección, Althusser sostiene que Feuerbach, cuya crítica materialista ha sido de gran influencia en el pensamiento marxista -sin embargo, Marx advierte que "Feuerbach no ve, por tanto, que el "sentimiento religioso" es también un producto social y que el individuo abstracto que él analiza pertenece en realidad, a determinada forma de sociedad"- no pudo historizar las representaciones ideológicas, quedando entrampado en los fundamentos de una teoría tradicional del conocimiento.

En el marco de un tratamiento tradicional del conocimiento, el sujeto es constituyente de la realidad, en la cual subyace la siguiente ecuación: "religión= conciencia de sí= esencia humana, puede leerse como un cogito cartesiano en el objeto que no es el pensamiento sino la religión" (QH: 13).Para Althusser, la filosofía feuerbachiana reposa sobre la identidad esencial entre el "sujeto" y el objeto, y esta identidad se explica por la omnipotencia de la esencia del hombre que se proyecta en la realización de sí que son sus objetos y en la alienación que separa el objeto del sujeto, 
que hace el objeto exterior al "sujeto", que lo reifica, e invierte así la relación de esencia. Es por ello que, Althusser inscribe la filosofía de Feuerbach -en la que el hombre es pensado como "esencia originaria y fin de su mundo" (SM: 240)- en la problemática ideológica del humanismo teórico, en la que incurre gran parte de la filosofía tradicional.

En esta línea de análisis, la filosofía tradicional habría retomado en las categorías de sus sistemas "tanto el derecho del hombre a conocer, el cual ella ha convertido en el sujeto de sus teorías del conocimiento, del cogito al sujeto empirista y al sujeto trascendental, como el derecho del hombre a actuar, el cual ha convertido en sujeto económico, moral y político" (ibíd.: 241)- de allí que esta filosofía tradicional represente "bajo formas no abiertamente declaradas, la tradición de un humanismo teórico incontestable" (Ídem). La categoría de hombre, de esencia humana o de especie humana, desempeña en este sentido, una función teórica esencial en la tradición filosófica. Ha sido Marx, según la lectura althusseriana, quien -tras haber aceptado en profundidad la problemática feuerbachiana de la esencia genérica del hombre y de la alienación- rompe con Feuerbach; propio del humanismo teórico.

Esta ruptura con la ideología humanista, para Althusser "marca de manera radical la historia de su pensamiento" (Ibíd.: 240). Y pone en tela de juicio conjuntamente las filosofías de la sociedad y de la historia existentes y la tradición filosófica clásica, y a toda la ideología burguesa. Por esa razón es que para Althusser, el antihumanismo teórico de Marx, va mucho más allá de un simple arreglo de cuentas con Feuerbach, ya que "cuestiona también las filosofías de la sociedad y de la historia existentes y la tradición filosófica clásica, y, por lo tanto, a través de ellas toda la ideología burguesa" (Ibíd.: 241).

La lectura de Marx por Althusser reconoce que este sustituye el concepto ideológico y universal de la práctica feuerbachiana por una concepción concreta de las diferencias específicas que permite situar cada práctica particular en las diferencias específicas de la estructura social” (RTM: 189- 190). Con lo cual destaca la función social y práctica de la ideología, para ir hacia las causas profundas de la crisis del marxismo y revitalizarlo. Sin embargo, Althusser aclara que no debe pensarse que se descarta sin más la ideología humanista ya que "el marxismo reconoce la existencia de las ideologías y las valora positivamente en función del papel que desempeñan en las luchas de clases" (SM: 242). Lo que se descarta, señala Althusser, es "la pretensión teórica de una concepción humanista de explicar la sociedad y la historia, partiendo de 
la esencia humana, del sujeto humano libre, sujeto de necesidades, del trabajo, del deseo, sujeto de la acción moral y política” (Ídem).

En este sentido, Althusser considera que, Marx habría podido fundar la ciencia de la historia y escribir El Capital a condición de romper con todo humanismo teórico, con el idealismo de Hegel como el mecanicismo de Feuerbach -que habría impregnado las obras de juventud al "hacer tabla rasa de Hegel y de toda la filosofía especulativa y que volvía a poner sobre sus pies ese mundo que la filosofía hacía marchar sobre la cabeza" (RTM: 34). Este proceso de ruptura a partir de 1845 en el pensamiento de Marx, es lo que luego le permitiría en El Capital demostrar que "lo que determina en última instancia una formación social y lo que posibilita el conocimiento de esta no es el fantasma de una esencia o de una naturaleza humanas, no es el hombre, no son siquiera "los hombres"; sino una relación, la relación de producción, que constituye la base, la infraestructura" (SM: 243).

Asimismo, esta relación de producción es una relación de distribución: distribuye a los hombres en clases, al mismo tiempo y según atribuye los medios de producción a una clase (las clases sociales surgen del antagonismo de esta distribución). Por tanto, el hombre de la producción se halla sometido a la ley de una relación de producción, que es una relación de explotación, por consiguiente, una ley antagonista de clase. Por ello es por lo que Marx, en la lectura althusseriana, considera que - en el marco de las relaciones capitalistas de producción- los hombres quedan reducidos a meros "soportes" de una relación, o "portadores" de una función en el proceso de producción. "completamente anónimos e intercambiables" (Ídem).

La ideología cumpliría así una función práctica fundamental al asegurar la cohesión de los hombres con sus tareas en la estructura general de la división de trabajo "para exaltar la expansión y la productividad al mismo tiempo que el Hombre y la libertad". Lo cual "permite a la pareja economicismo/humanismo, que expresa el punto de vista burgués, trabajar para disimular, asegurar y reproducir las relaciones de explotación" (RTM: 97) invisibilizando las relaciones de producción y la lucha de clases. Desde esta perspectiva, las relaciones sociales ya no pueden ser pensadas como relaciones simplemente humanas, sino que son relaciones entre agentes de la producción, entre hombres que tienen una función bien determinada en la producción de bienes materiales.

Siguiendo a Marx, Althusser afirma que esta relación variará si estos son propietarios de los medios de producción o productores directos. Y para que estos 
lugares sean ocupados de acuerdo a lo previsto por el sistema de producción capitalista, la ideología jugará un rol central, dada su función práctica y social.

\section{La función práctica de la ideología}

Ser marxista en filosofía es entrar en el debate filosófico para representar la ciencia de la filosofía a la que se juzga, en última instancia, como una forma teórica de la política, y, por ende, de la ideología. (Althusser, Ser marxista en filosofia)

El reconocimiento del humanismo como ideología requiere, según advierte Althusser en Marxismo y humanismo, una precisión previa que consiste en conocer la naturaleza de la ideología. En esta dirección, Althusser indaga qué es una ideología, y responde que esta es un sistema (que posee su lógica y su eficacia propia) de representaciones (de imágenes, mitos, ideas o conceptos, según los casos), dotados de una existencia y de un papel históricos en el seno de una sociedad dada, ya que tiene "una función práctico- social más importante que la función teórica (o de conocimiento)" (Ídem).

El estatuto central que adquiere la función práctico social de la ideología, rompe con la concepción idealista de la ideología y permite comprenderla como una parte orgánica y fundamental de las formaciones sociales, entendidas como totalidades, cuya unidad -como analizaremos en el próximo capítulo- está constituida por un cierto tipo específico de complejidad, que pone en juego distintas instancias: la económica, la política, y la ideológica. En palabras de Althusser:

...las sociedades humanas secretan la ideología como el elemento y la atmósfera misma indispensable a su respiración, a su vida históricas. Sólo una concepción ideológica del mundo pudo imaginar sociedades sin ideologías, y admitir la idea utópica de un mundo en el que la ideología (y no una de sus formas históricas) desaparecerá sin dejar huellas, para ser reemplazada por la ciencia....

Ahora bien, reconocer que la instancia ideológica constituye una estructura esencial en la vida histórica de las sociedades posibilita -según Althusser- "a actuar sobre la ideología y transformarla en instrumento de acción sobre la Historia” (Ídem). En contraposición a la problemática idealista de la ideología, para Althusser la ideología 
tiene muy poco que ver con la conciencia, (suponiendo que este término tiene un sentido unívoco). Sino que "es profundamente inconsciente, aun cuando se presenta bajo una forma reflexiva (como en la filosofía premarxista)" (Ídem. Cursiva del original).

La inscripción de la ideología en un tratamiento materialista, implica reconocer que está constituida por objetos culturales percibidos, aceptados- soportados que actúan funcionalmente sobre los hombres "mediante un proceso que se les escapa", que no eligen y que no fundan. En este sentido, los hombres "viven" su ideología como un objeto de su mundo. Se trata entonces de la manera en que los hombres "viven su relación con sus condiciones de existencia: lo que supone a la vez una relación real y una relación "vivida", "imaginaria" 25 (...). La relación real, sostiene Althusser, está inevitablemente investida en la relación imaginaria, que expresa más una voluntad que la descripción de una realidad" (Ibíd.: 194).

Esta doble naturaleza de la ideología, en tanto material e imaginaria, manifiesta asimismo que, esta tiene la capacidad de transformar materialmente la relación de los hombres en esa misma relación imaginaria. Todo ello, porque la ideología es un instrumento de las clases dominantes "para enrolar en sus filas, formándolos con este fin, a los mismos hombres que no liberará, sino para explotar" (Ídem.). Lo que es ilustrado con el hecho de que cuando la burguesía asciende, desarrolla en el curso del siglo XVIII una ideología humanista de la igualdad, de la libertad y de la razón; y le otorga a su reivindicación, una forma universal. En esta línea se ubica para Althusser, el mito rousseniano del origen de la desigualdad: "los ricos dirigen a los pobres el discurso más reflexivo" (Ídem.) para convencerlos de vivir su servidumbre como libertad.

En el marco de la ideología de la libertad, advierte Althusser, la burguesía tiene una relación real con sus condiciones de existencia (el derecho de la economía capitalista liberal), pero investida de una relación imaginaria (todos los hombres son libres, incluso los trabajadores libres). Su ideología consistiría así, en usar un discurso ("el chantaje" dice Althusser) sobre la libertad para mistificar a sus explotados ("libres") para mantenerlos sometidos. Pero su argumento va más allá, ya que la clase dominante tampoco es libre, ya que para explotar "se sirve de una ideología, no puede sino estarle

\footnotetext{
${ }^{25}$ Esta dimensión imaginaria tiene un fuerte vínculo con el materialismo de lo imaginario de Spinoza que profundizaremos en la II parte.
} 
sometida"26 (Ibíd.: 195). La ideología mantiene así una estrecha relación con la estructura social. No es un mito o un poder que actúa desde el exterior, sino que "en tanto sistema de representaciones de masas, es indispensable a toda sociedad para formar a los "hombres", transformarlos y ponerlos en estado de responder a las exigencias de sus condiciones de existencia.

Ahora bien, al rechazar la esencia del hombre como fundamento teórico, Marx según Althusser- funda una nueva problemática, una nueva manera sistemática de plantear los problemas al mundo, nuevos principios y nuevo método. Este descubrimiento está contenido, según Althusser, en la teoría del materialismo histórico, donde Marx propone "una nueva "filosofía" con implicaciones infinitas" (Ibíd.: 189), y reemplaza los postulados idealistas por un materialismo dialéctico de la praxis.

Esta nueva filosofía implica el rechazo de la esencia del hombre como fundamento teórico, así "como el rechazo de las categorías filosóficas de sujeto, empirismo, esencia ideal, etc. de todos los campos en que reinaban" (Ídem.). Es decir, no sólo de la economía política (rechazo del mito del homo oeconomicus: del individuo con facultades y necesidades definidas en tanto que sujeto de la economía clásica; sino también de la historia: rechazo del atomismo social y el idealismo político- ético; así como de la moral: rechazo de la moral kantiana. Sino también de la filosofía misma ya que el materialismo de Marx excluye el empirismo del sujeto "y su reverso el sujeto trascendental"; y el idealismo del concepto "y su reverso el empirismo del concepto".

Frente a la pretensión del humanismo de postular a un sujeto constituyente de la realidad, libre y autónomo de sus acciones y elecciones, Althusser sostiene que el "sujeto" "no desempeña el papel que cree sino el que le es asignado por el mecanismo del proceso" (PLC: 33). Sin embargo, la falsa ilusión de autonomía por parte del sujeto, y el desconocimiento de su sujetamiento, es el "efecto ideológico fundamental" e "indispensable a toda sociedad para formar a los hombres, transformarlos y ponerlos en estado de responder a las exigencias de sus condiciones de existencia” (RTM: 194).

Ahora bien, cabe señalar que, "el descentramiento del sujeto" que Althusser despliega en Marxismo y humanismo, en Para leer El Capital y en La revolución teórica de Marx, bajo la tesis del antihumanismo teórico, y bajo la primacía de las

\footnotetext{
${ }^{26}$ Esto recuerda a la famosa interpretación de la "Dialéctica del Amo y el esclavo" que Alexándre Kójeve (1982) realiza del capítulo IV de la Fenomenología del Espíritu de Hegel, desde una clave existencialista, según la cual no puede haber libertad propiamente dicha, sin que las relaciones de dominación sean abolidas. De allí el dilema existencialista en el que se encuentra el amo, al no poder hacer más que dominar al esclavo, pero eso justamente, lo aprisiona.
} 
estructuras de las relaciones de producción; toma una forma específica en sus textos de autocrítica, al concebir la historia como un proceso sin sujeto ni fines. Allí, el problema del sujeto aparece planteado en los siguientes términos:

Todo individuo humano, es decir social, sólo puede ser agente de una práctica social si reviste la forma de sujeto. La "forma-sujeto" es en efecto la forma de existencia histórica de todo individuo, agente de prácticas sociales: puesto que las relaciones sociales de producción y reproducción comprenden necesariamente, como parte integrante, lo que Lenin llama "las relaciones sociales [jurídico-] ideológicas." que, para "funcionar", imponen a todo individuo-agente la forma de sujeto. Los individuos agentes actúan por lo tanto siempre en la forma de sujetos, en tanto sujetos. Pero que ellos sean necesariamente sujetos, no hace a los agentes de las prácticas sociales-históricas el, ni los sujeto(s) de la historia (en el sentido filosófico del término: sujeto de). Los agentes- sujetos sólo son activos en la historia bajo la determinación de las relaciones de producción y reproducción, y en sus formas.

(PPT: 76- 77)

Asimismo, este rechazo a la categoría idealista de "Sujeto" como Origen, Esencia y Causa, se manifiesta también en el "el último Althusser" (como examinaremos al final de este capítulo) el precursor de una "nueva filosofia", la del materialismo aleatorio, "no es la de un sujeto (sea Dios o el proletariado) sino la de un proceso -sin sujeto- que domina el orden de su desarrollo, sin fin asignable" (ME: 31).

Entonces bien, de acuerdo con el análisis althusseriano, los hombres en sus prácticas reales-ya sean económicas o políticas- se encuentran determinados por las estructuras objetivas (relaciones de producción, relaciones políticas de clase) pero no pueden llegar por esta sola práctica al conocimiento verdadero de estas estructuras, ya que no poseen conocimiento de estos mecanismos. El conocimiento de las estructuras económicas y políticas es el resultado de otra práctica: la práctica científica, distinta de esas prácticas inmediatas.

Ello implica romper con la concepción idealista del conocimiento, y de una de sus variaciones: la concepción empirista del conocimiento. Subyacente también en las interpretaciones historicistas que no distinguen entre objeto de conocimiento y objeto real. Por ello es que en Escritos sobre la historia ([1963- 1968] 2019) Althusser señale que, la tesis del antihistoricismo (o ahistoricismo) del marxismo está destinada a poner en evidencia la distinción entre la historia vivida y el conocimiento de la historia. 


\title{
La crítica a la concepción empirista del conocimiento
}

\author{
Se pone en cuestión la idea que "lo real es el resultado del pensamiento", \\ y se muestra siguiendo la Introducción, que el conocimiento de esas "leyes que \\ ordenan tanto su vida como sus luchas concretas" es el resultado de un proceso de \\ producción. \\ (Althusser, Para leer El capital)
}

De acuerdo con la lectura de Althusser, el conocimiento en el marco de un tratamiento tradicional, de tipo empirista - propio de la Filosofía de las luces, pero que también incluye a la filosofía de Hegel- consiste en abordar el conocimiento científico como el resultado de una relación preexistente entre un sujeto y un objeto, que precede al trabajo científico; es decir, que se encuentra determinado previamente, cuyo resultado es distinguir en el objeto real, lo esencial de lo accesorio, mediante un proceso de abstracción $^{27}$.

De la misma manera que el oro antes de su extracción, existe como oro no separado de su escoria en su escoria misma; igualmente -sostiene Althusser- la esencia de lo real existe, como esencia real, en lo real que la contiene. Lo que manifiesta que "el conocimiento es abstracción, en sentido propio, es decir, extracción de la esencia de lo real que lo contiene y lo encierra ocultándolo" (PLC: 41). Por tanto, el proceso de conocimiento en una teoría de conocimiento de tipo empirista es abstracción ya que consiste en extraer del objeto real una esencia, dejando de lado lo inesencial- la parte del objeto real que es visible- mientras que lo esencial ocuparía el interior, sería "su núcleo invisible" (Ibíd.: 42).

Sin embargo, la representación de este procedimiento de eliminación no aparece en el resultado, sino en la estructura misma del objeto real (Ibíd.: 42. Énfasis agregado). Althusser afirma que si se logra concebir claramente esta estructura fundamental, también se podrá ver que las formas modernas del empirismo, "que se nos presentan bajo los títulos de una teoría de los modelos" ${ }^{28}$, por ejemplo, identifican el modelo con

\footnotetext{
${ }^{27}$ Enrique Eduardo Marí hace una notable aclaración sobre el término “abstracción”. Y nos ofrece buenas razones para utilizar, en el caso señalado, el término "mala abstracción", ya que este último término refiere justamente a la "operación empirista consistente en separar del objeto real una supuesta esencia cuya posesión por el sujeto se llamaría conocimiento” (Marí, 1974: 167-168).

28 "la concepción empirista del modelo como ideología del conocimiento recibe, de la confusión entre el instrumento técnico que es un modelo y el concepto del conocimiento, todas las apariencias necesarias para su impostura." Althusser señala que esta impostura se puede observar también en Feuerbach que intentaría liberarse de la ideología invocando "lo concreto", es decir, el concepto ideológico de la
} 
el objeto de conocimiento; en las que el sujeto con una mirada "informada" (una mirada que pueda distinguir entre la esencia y sus fenómenos) puede penetrar en el objeto de conocimiento" (Callinicos, 1978: 32). En este sentido, existe un vínculo entre la problemática precientífica de la lectura humanista y el empirismo ya que, de acuerdo con la epistemología empirista, lo real se encuentra presente de inmediato en los fenómenos accesibles a nuestra observación, ya que existe una relación preestablecida entre sujeto y objeto: la estructura del objeto de conocimiento es de tal forma que "hace posible la penetración de la mirada del sujeto de lo contingente hasta lo real" (Ibíd.: 32$33)$.

En efecto, Althusser señala que desde la posición empirista del conocimiento el "todo" del conocimiento está investido en lo real, y el conocimiento no aparece sino exclusivamente como una relación interior al objeto real; entre partes realmente distintas de ese objeto real. El conocimiento es desde este marco, una relación interior al objeto real, entre sus partes exterior (inesencial) e interior (esencial). El objeto de conocimiento "distinto" al objeto real, en esencia, es lo mismo. Por ello, es que desde esta concepción empirista del conocimiento no se puede reconocer que el objeto de conocimiento y el objeto real son, desde un aspecto: iguales, ya que habría una esencia que ambos comparten; y diferentes: ya que el objeto real, a diferencia del objeto de conocimiento, posee, además de la esencia común, accidentes ${ }^{29}$.

El objeto de conocimiento que supuestamente construye el abordaje empirista del conocimiento, es en realidad, ya parte del objeto real sobre el que interviene un juego de palabras que hacen que "el todo del conocimiento está entonces investido en lo real, y el conocimiento no aparece sino exclusivamente como una relación, interior al objeto real, entre partes realmente distintas de este objeto real" (PLC: 44). En palabras de Althusser:

Cuando el empirismo señala la esencia como objeto del conocimiento, confiesa algo importante que al mismo tiempo niega, confiesa que el objeto del conocimiento no es idéntico al objeto real, puesto que lo declara solamente parte del objeto real. Pero niega lo que confiesa, reduciendo, precisamente, esa diferencia entre dos objetos, el objeto de conocimiento y el

confusión entre el conocer y el ser, pero "es evidente que la ideología no puede liberar de la ideología" (PLC: 45).

${ }^{29}$ En esta línea, Pedro Karczmarczyk (2014) retoma la metáfora mineralógica para señalar que el objeto real es no sólo el núcleo de metal precioso, sino también escoria; de manera que, lo real sería real y no real a un mismo tiempo. 
objeto real, a una simple distinción de las partes de un solo objeto: el objeto real. En el análisis confesado hay dos objetos distintos, el objeto real que "existe fuera del sujeto, independientemente del proceso del conocimiento" (Marx) y el objeto de conocimiento (la esencia del objeto real) que es ciertamente distinto del objeto real. En el análisis negado, ya no hay más que un solo objeto: el objeto real.

(PLC: 46)

Entonces bien, Althusser descubre un juego de palabras (síntoma) operando en el propio concepto de lo real, mostrando que esta paradoja es tanto intrínseca a la epistemología tradicional como insoluble; y por ello, propone colocar a la cuestión epistemológica bajo otra problemática, bajo otro modelo, el de la producción. Ante esta "impostura" de la concepción empirista del conocimiento, Althusser propone abrir el camino de lo que se puede denominar una "epistemología materialista" que tiene como referencia la distinción de Spinoza entre la idea de círculo y el círculo ${ }^{30}$, distinción que Marx profundizó en la Introducción de los Gründisse al rechazar la identificación hegeliana entre concreto real y concreto de pensamiento. Althusser, por su parte, va a distinguir entre el objeto del pensamiento y el objeto real, ya que según él remiten a procesos de producción distintos: la génesis real histórica y la génesis cognoscitiva.

En el marco de una filosofía materialista, el proceso de conocimiento será pensado como un proceso que no tiene solución, que no tiene fin, que carece de término y de orientación predeterminada. Lo que implica el rechazo a toda garantía, así como también a los conceptos de Sentido, Origen, Fin, Sustancia, que se articulan con el de Sujeto- centro.

\footnotetext{
${ }^{30}$ Spinoza afirma que el objeto de conocimiento o esencia es "en sí" absolutamente distinto del objeto real, "según su alerta a no confundir la idea de círculo (objeto cognoscitivo) con el círculo real (objeto real)" (Marí, 1974: 162).
} 


\section{Capítulo II. El conocimiento del todo complejo sobredeterminado}

...El mundo es la totalidad de lo que acaece...

(Wittgenstein, Tractatus lógico- político)

De acuerdo con la lectura de Althusser, el proceso de conocimiento -que ocurre en el pensamiento, entendido desde su materialidad- se produce conforme a mecanismos específicos que constituyen la práctica teórica. Explorar estos mecanismos específicos de la práctica de producción de conocimiento, implica un proceso que va de lo abstracto a lo concreto de pensamiento, siguiendo el método del materialismo dialéctico formulado por Marx en El capital y en la Introducción de 1857. De este análisis se desprende, según Althusser, la concepción de la totalidad social como un todo complejo estructurado con dominante, con diversas instancias articuladas y sobredeterminadas a partir de una estructura que está presente a través de sus efectos, la causalidad estructural.

Explorar en qué consiste la causalidad estructural, la naturaleza de la contradicción sobredeterminada y su lugar dentro del todo complejo articulado, constituyen el objetivo principal de este capítulo. 


\section{El modo de producción (materialista) de conocimiento}

...el proceso de producción del conocimiento ocurre enteramente en el pensamiento.

(Althusser, Para leer El capital)

Contra el empirismo, Marx, según Althusser sostenía que el conocimiento va de lo abstracto a lo concreto, y que todo ello ocurre "en el pensamiento"; mientras que el objeto real, que da lugar a todo este proceso, existe fuera del pensamiento. Y contra Hegel, Marx sostenía que este proceso de lo abstracto a lo concreto no era producción de lo real, sino tan sólo de su conocimiento: "El conocimiento es un producto del pensar, del concebir (...) es un producto de la elaboración de conceptos a partir de la intuición y de la representación" (SM: 234).

Ahora bien, desde esta lectura Marx seguiría los pasos de Spinoza en su propuesta de distinguir entre el orden lógico y el orden histórico, pero lo hace en el campo de una problemática científica que distingue entre el objeto real y el objeto de conocimiento. Bajo tal distinción, el objeto de conocimiento no es lo concreto preexistente a las abstracciones con las que los hombres aprehenden la realidad, la materia que tiene primacía sobre el pensamiento, sino la materia en tanto que ya ha sido aprehendida por alguna práctica humana en donde se presenta como lo real.

Esta distinción, según Althusser, se halla inscrita en Marx cuando, por ejemplo, en la "Introducción" a la Crítica de la Economía Política señala que "parece justo comenzar por lo real y lo concreto, por ejemplo, en la economía política, por la población. Sin embargo, si contemplamos las cosas con mayor detenimiento nos damos cuenta de que se trata de un error: la población es una abstracción" (cfr. Ídem) ${ }^{31}$. Es decir que la intuición y la representación son abstracciones. El conocimiento es entonces para Marx, el conocimiento de un objeto real, que "subsiste antes como después en su independencia fuera del espíritu" (I: 167; Cfr. SM: 235).

Marx distinguiría así, según Althusser entre la actitud teórica (conocimiento del objeto real) y la actitud práctica (transformación del objeto real). La sociedad como objeto de estudio "sigue estando constantemente presente para el espíritu en tanto que presuposición de todo proceso de conocimiento de un objeto real, fuera del

\footnotetext{
${ }^{31}$ Albert Roies (1974) señala al respecto que Marx no cayó nunca en la ilusión idealista de creer que el conocimiento de un objeto teórico puede reemplazar o eliminar su existencia real, por ejemplo: el conocimiento de la naturaleza del dinero no basta para destruir su existencia.
} 
pensamiento" (Ídem). Sin embargo, esta exterioridad del objeto real, la existencia de este objeto real, se afirma al mismo tiempo que se afirma el carácter propio del proceso de pensamiento, que "produce mediante un trabajo de elaboración" conceptos a partir de la intuición y de la representación. Y al final del proceso, lo concreto de pensamiento, la totalidad de pensamiento que es el resultado de este se presenta como el conocimiento de lo concreto- real, del objeto real.

Bajo tal distinción, el objeto de conocimiento no es lo concreto preexistente a las abstracciones con las se aprehendería la realidad, la materia que tiene primacía sobre el pensamiento; sino la materia en tanto que ya ha sido aprehendida por alguna práctica humana en donde se presenta como lo real. Pero, además, esta distinción (entre el objeto real y el objeto de conocimiento) se refiere no sólo a esos dos objetos, sino también a sus propios procesos de producción, en tanto que, el proceso de producción del conocimiento ocurre "enteramente en el pensamiento", entendido desde su materialidad.

Tal reconceptualización en el proceso de producción de conocimiento implica una crítica radical a la concepción empirista del conocimiento que identifica entre objeto real y objeto de conocimiento, donde estos tendrían un origen común. Por tanto, el telos del conocimiento consistiría en recuperar este origen y dirigirse hacia él. En el plano de la historia, las concepciones empiristas y teleológicas se encuentran en el historicismo según Althusser que, reduce el objeto (teórico) de la ciencia de la historia, a la historia real.

Para Althusser, "aunque todo conocimiento cuando se adquiere es, el conocimiento de un objeto real que permanece tanto antes como después independientemente del espíritu (...) el intervalo que separa el antes del después, es el propio proceso de conocimiento" (Ídem.). Esto lo lleva a postular que "si el proceso de conocimiento no transforma el objeto real, sino únicamente su intuición en conceptos, después en concreto de pensamiento" (Ídem.). Y si todo este proceso ocurre, como repite Marx, en el 'pensamiento' y no en el objeto real ello quiere decir que, en el caso del objeto real, y para conocerlo, el pensamiento trabaja sobre otra 'materia"'(Ídem.). Lo cual implica que el pensamiento trabaja sobre otra materia que no es el objeto real: trabaja sobre las formas transitorias que lo designan en el proceso de transformación para producir su concepto, lo concreto de pensamiento que no debe confundirse con el concreto real. A diferencia del tratamiento empirista del conocimiento, en el tratamiento propuesto por Althusser - siguiendo a Marx- el conocimiento de lo concreto no se halla al comienzo sino al final del análisis, donde el proceso de conocimiento "añade a cada 
paso a lo real su propio conocimiento" (Ibíd.: 237). Con lo cual se modifica algo en lo real, ya que le añade justamente su conocimiento, pero esta adición se anula en su resultado ya que "una vez producido se incorpora a lo real de pleno derecho y desaparece en él.

En el nuevo marco, el ciclo infinito de todo conocimiento se mantiene vivo al producir conocimientos nuevos, como ocurre -según Althusser- con el trabajo en la teoría de Marx el que "es preciso que añada un valor nuevo a los objetos", para que el valor del "trabajo muerto", contenido en los medios de producción se conserve y se transmita al producto, ya que "es la simple adición de un nuevo valor lo que mantiene al antiguo" (Cfr. Ídem.).

Ahora bien, si para Althusser las tesis de Marx del primado del objeto real sobre el objeto de conocimiento -que permite distinguir entre objeto real y objeto de pensamiento- son tesis materialistas que se desmarcan del idealismo y "abren la posibilidad de investigar los procesos concretos de la producción de conocimientos" (Ibíd.: 236), ¿cómo ocurre la apropiación de la contradicción entre objeto real y objeto de conocimiento en el proceso de conocimiento?

La lectura filosófica propuesta por Althusser intenta mostrar que la apropiación de la contradicción no es apropiación de un objeto por parte de un sujeto- como podría ser al comprender la categoría de clase a partir de la categoría sujeto en la que esta queda reducida a objeto -propio de un análisis empírico, e idealista del conocimientosino que este pensamiento es el sistema históricamente constituido de un aparato de pensamiento, basado y articulado en la realidad social. A partir de esta reformulación, Althusser propone comprender que el proceso de producción del conocimiento ocurre “enteramente en el pensamiento" (PLC: 47) que implica la naturaleza material del pensamiento, que ya no puede ser concebido como la facultad de un sujeto trascendental o de una conciencia absoluta; sino que, contrariamente, se lo comprende como determinado por el sistema de condiciones reales que hacen de él un "modo de producción determinado de conocimientos" (Ídem.).

El pensamiento está, en el nuevo marco, constituido por una estructura que combina el tipo de objeto sobre el cual trabaja (la materia prima), los medios de producción teórica de los que dispone (teoría, método, técnicas, etc.) y las relaciones históricas en las que se produce. A su vez, "este sistema definido de las condiciones de la práctica teórica es el que asigna a tal o cual sujeto (individuo) pensante su lugar en la producción de conocimientos" (Ídem). De allí que Marx, según esta lectura filosófica, 
sostenga en la Introducción de 1857 que "el sujeto real mantiene, antes como después, su autonomía fuera de la mente" (I: 22). Y que en sintonía con ello Marx señale en El capital: "mi método analítico no parte del hombre, sino del período social económicamente dado." Puesto que "la sociedad no está compuesta de individuos" (Ibíd.: 37).

Partir del hombre es -como hemos anticipado siguiendo a Althusser- propio de un tratamiento ideológico, ya que "el hombre como punto de partida es un mito"; mientras que, el marxismo-leninismo, parte en cambio, "del período social económicamente dado" y al término de su análisis puede llegar a los hombres reales" (ídem) y a la explicación de las formaciones sociales y de su historia. La ruptura teórica de Marx en este sentido consistiría en la fundación de la ciencia del materialismo histórico, pero no pensado desde el concepto de hombre -entendido como sujeto originario de sus necesidades (homo oeconomicus), de sus pensamientos (homo rationalis), de sus actos y de sus luchas (homo moralis, juridicus et politicus) - sino con conceptos completamente distintos: relación de producción, lucha de clases, relaciones jurídicas, políticas, ideológicas.

En esta línea, Marx parte de la formación económica dada, en el caso de $E l$ capital, de la relación de producción capitalista, y de las relaciones que esta determina en última instancia en la superestructura. Estas relaciones determinan y marcan a los hombres en su vida concreta; así como a través del sistema de la lucha de clases, los hombres concretos son determinados por el sistema de estas relaciones. Althusser afirma que "El método científico correcto" consiste en partir de lo abstracto para producir lo concreto en el pensamiento, siguiendo en esto a Marx y su análisis de la Introducción. Allí Marx distingue el objeto real del objeto de conocimiento, poniendo en evidencia "una diferencia de orden en la génesis de estos procesos" (PLC: 52). Y extraía la conclusión de que el concepto de población "aparentemente lo más concreto" no puede ser el punto de partida de la investigación precisamente porque es abstracto.

Lo anterior nos da una clave para comprender por qué en El capital Marx comienza con la riqueza, que es un concepto empírico, inmediatamente dado por la economía, o sea: ideológico. La riqueza, el objeto real dado en la ideología, no es el punto de partida, pero es "el lugar a partir del cual la exposición puede comenzar a mostrar sus conceptos fundamentales" (Ibíd.: 55). Este concepto, a pesar de estar al inicio de la investigación, es un concepto empírico que requiere de otros conceptos para poder completar el análisis del modo de producción capitalista. 
Ahora bien, el método de análisis -que Marx considera preexistente "al igual que esa dialéctica que declara haber tomado de Hegel" (Ibíd.: 57) en realidad son inventados por Marx- y no son, sino una sola y misma cosa, no basta para explicar su producción original, señalar que ella sólo ha sido posible al precio de una ruptura con Hegel" (Ídem). Althusser examina que el método de análisis de Marx es lo mismo que el modo de exposición (Darstellungweise) y que distingue "cuidadosamente" del modo de investigación (Forschungsweise). Si este último, es la búsqueda concreta que Marx efectuó durante años en los documentos existentes y los hechos que estos documentos atestiguan; Althusser señala que, si bien los protocolos de la investigación de Marx están en parte contenidos en sus notas de lectura, en El capital nos encontramos con algo muy diferente: “con la exposición sistemática, con la puesta en orden apodíctico de los conceptos en la forma propia a este tipo de discurso demostrativo" (Ídem.).

El discurso de El capital constituye entonces una clave para elucidar el efecto de conocimiento, ya que en este marco lo concreto es concreto porque es la síntesis de múltiples determinaciones, por lo tanto, unidad de lo diverso. De manera que aparece en el pensamiento como proceso de síntesis, como resultado. Mientras que en el método de la economía política clásica ocurre lo contrario: lo concreto aparece como punto de partida.

David Harvey en su Guía de lectura de El capital afirma que la novedad del análisis de Marx en El capital estriba en que su método de investigación comienza con "con la realidad tal como es experimentada" (Harvey, 2014: 14). A partir de la cual se "desciende" hacia la búsqueda de conceptos que la definan; y luego, se "asciende" a la superficie para poner de manifiesto lo engañoso de las apariencias: "Marx comienza desde el exterior de la cebolla, a través de capas de la realidad externa hasta alcanzar su centro, el núcleo conceptual" (Ibíd.: 16) ${ }^{32}$. En esta línea, el análisis de Althusser en Para leer El capital reconoce que la mercancía es la forma elemental de la riqueza, y esta última es el cúmulo de mercancías- concepto que requiere de la abstracción. En este marco, el valor de uso es la forma elemental de la riqueza, mientras que el valor de cambio es el límite del concepto empírico. Ambos conceptos se reconocen y distinguen a partir de la mercancía.

\footnotetext{
${ }^{32}$ Silvia Rivera Cusicanqui afirma al respecto: "estas fórmulas fueron pensadas con una racionalidad muy analítica, propia de la filosofía alemana y sirven para desentrañar las capas de la mercancía del presente, como se lo hace con una cebolla, para extraer de ella sus fórmulas elementales y la lógica estructural de su funcionamiento" (Cusicanqui, 2018: 43).
} 
Ahora bien, atendiendo a su método Althusser aclara que no hay que creer que "lo abstracto" designaría la teoría misma (ciencia) mientras que "lo concreto" designaría lo real, las realidades "concretas" de las cuales la práctica teórica produce el conocimiento. $\mathrm{Y}$ advierte también, sobre el riesgo de confundir dos concretos diferentes: el concreto de pensamiento que es un conocimiento -que se desarrolla entero en la práctica teórica- y el concreto-real que es su objeto, y que, "subsiste, antes como después, en su independencia, externo al pensamiento; sin que jamás pueda ser confundido con ese otro "concreto" que es el conocimiento" (PLC: 153).Esta distinción es fundamental para reconocer que, en el seno mismo del proceso de conocimiento, la generalidad "abstracta" a partir de la cual el proceso de conocimiento comienza, y la generalidad "concreta" en la que termina, no son desde el punto de vista de su esencia, la misma generalidad.

En sus Notas sobre Wagner (1881) Marx presenta un ejemplo de este concepto de lo abstracto como "resultado" y como punto de partida a la misma vez, cuando señala: "Yo parto de la forma social más simple en que toma cuerpo el producto del trabajo en la sociedad actual, que es la mercancía" (Cfr. Roies, 1974: 27). Con lo cual se refuerza la propuesta de Marx de comenzar el análisis por lo concreto y lo real, como un supuesto efectivo. En el caso de la economía, este supuesto es la población, la base y el sujeto de la producción en su conjunto. Sin embargo, Marx detecta que, si esto se examina con mayor atención, y se deja de lado las clases que la componen, se revela que la población es una abstracción. Estas clases son a su vez, "una palabra huera" si se desconocen los elementos sobre los cuales reposan, por ejemplo, el trabajo asalariado, el capital, etc. Estos últimos suponen el cambio, la división del trabajo, los precios, etc. El capital señala Marx "no es nada sin trabajo asalariado, sin valor, dinero, precios, etc. Si comenzara por la población, tendría una representación caótica del conjunto y, precisando cada vez más, llegaría analíticamente a conceptos cada vez más simples" (I: 21).

En esta línea, si atendemos a la categoría económica más simple, el valor de cambio, advertimos que esta supone "una población que produce en determinadas condiciones, y también un cierto tipo de sistema familiar o comunitario o político, etc.". Este valor, asegura Marx, no puede existir de otra manera que no sea bajo la relación unilateral y abstracta de un todo concreto y viviente ya dado. Lo mismo vale al explorar la posesión. Marx detecta que el análisis hegeliano en la Filosofía del derecho "cayó en la ilusión de concebir lo real como resultado de pensamiento que, partiendo de sí 
mismo, se concentra en sí mismo y se mueve por sí mismo, mientras que el método que consiste en elevarse de lo abstracto a lo concreto es para el pensamiento sólo la manera de apropiarse lo concreto. Pero esto no es de ningún modo el proceso de formación de lo concreto mismo" (I: 21-22) porque:

(...) la totalidad concreta, como totalidad del pensamiento, como concreto del pensamiento es, in fact* un producto del pensamiento y de la concepción, pero de ninguna manera es un producto del concepto que piensa y se engendra a sí mismo, desde fuera y por encima de la intuición y de la representación, sino que, por el contrario, es un producto del trabajo de elaboración que transforma intuiciones y representaciones en conceptos. El todo, tal como aparece en la mente como todo de pensamiento, es un producto de la mente que piensa y que se apropia el mundo del único modo posible, modo que difiere de la apropiación de ese mundo en el arte, la religión, el espíritu práctico (...).

Entonces bien, bajo la perspectiva materialista de Marx, en la lectura de Althusser, no existe posesión antes de la familia o de las relaciones de dominación y de servidumbre, que son relaciones mucho más concretas. En este sentido, afirma que sería justo decir que existen familias, tribus, que se limitan a poseer, pero que no tienen propiedad. Frente a la propiedad, la relación de simples familias o pequeñas comunidades aparece como la categoría más simple. Pero en la sociedad de un nivel más elevado la propiedad aparece como la relación más simple dentro de una organización desarrollada. Sin embargo, el sustrato más concreto, cuyo vínculo es la posesión, está siempre supuesto.

Siguiendo la lectura de Marx por Althusser, no es exacto decir que la posesión evoluciona históricamente hacia la familia. Por el contrario, ella presupone siempre esta categoría jurídica más concreta. En este marco "puede afirmarse que la categoría más simple puede expresar las relaciones dominantes de un todo no desarrollado o las relaciones subordinadas de un todo más desarrollado" (I: 23). Pero ¿las categorías más simples tienen existencia histórica anterior a las categorías concretas? De acuerdo con el análisis de la Introducción "las abstracciones más generales surgen únicamente allí donde existe el desarrollo más rico" (Ibíd.: 25).

Lo mismo ocurre con la categoría de trabajo que "se ha convertido, en tanto categoría, pero también en la realidad, en el medio para crear la riqueza en general, y ha 
dejado de adherirse al individuo como particularidad suya" (Ídem.). Con este ejemplo del trabajo lo que Marx pretende mostrar es que, incluso, en las formas más abstractas a pesar de su validez para todas las épocas (por ser abstractas justamente) estas son el producto de condiciones históricas determinadas. De allí que señale: "si es verdad que las categorías de la economía burguesa poseen cierto grado de validez para todas las otras formas de sociedad, esto debe ser tomado cum grano salis*" (Ibíd.: 27).

Ahora bien, Althusser plantea dos problemas teóricos fundamentales para la comprensión de la teoría de Marx, cuyo objeto de estudio "es la sociedad burguesa actual". Remarca que estos problemas son distintos y no deben ser confundidos:

Existe, por cierto, un problema teórico que hay que plantear y resolver para explicar el mecanismo por el cual la historia ha producido como resultado el modo de producción capitalista actual. Pero existe, al mismo tiempo, otro problema teórico, absolutamente distinto, que hay que plantear y resolver para comprender que este resultado es ciertamente un modo social de producción, que este resultado es precisamente una forma de existencia social, y no cualquier otra existencia: este segundo problema es lo que constituye el objeto de la teoría de EC, sin confundirse ni un solo instante con el primero.

Marx, según Althusser, considera a la sociedad como un resultado y como una sociedad, ambos problemas conciernen al continente Historia. Pero El capital hace abstracción del primero de ellos, esto es, el de pensar la sociedad como resultado histórico, y se concentra en el segundo, elaborando así una teoría del "mecanismo de producción del efecto sociedad en el modo de producción capitalista" (PLC: 73). A diferencia de Hegel que "concibe lo real como resultado del pensamiento que se concentra en sí mismo" hace una doble confusión: 1) toma el trabajo de la producción de un conocimiento científico por "el proceso de la génesis de lo concreto mismo"confusión que se apoya en otro equívoco: 2) tomar el concepto universal que figura al comienzo del proceso de conocimiento- por la esencia y motor de este proceso, por "el concepto que se engendra a sí mismo" (Ibíd.: 154- 155). Para Althusser, el movimiento "dialéctico" a través del cual lo universal abstracto se produce a sí mismo como concreto, reposan -siguiendo este análisis- sobre la confusión de los diferentes tipos de abstracción que actúan en la práctica teórica. 


\section{La práctica teórica}

...Saber lo que es una ciencia significa ante todo saber cómo se constituye, cómo es producida: mediante un inmenso trabajo teórico específico, una práctica teórica irremplazable, extremadamente larga, ardua y difícil...

(Althusser, Lenin y la filosofía)

De acuerdo con la lectura de Althusser, Marx puede plantear la pregunta por el modo de producción de conocimiento: “¿mediante qué mecanismo el proceso de conocimiento -que ocurre enteramente en el pensamiento- produce la apropiación cognoscitiva de su objeto real, que existe fuera del pensamiento en el mundo real?" (PLC: 63). Una pregunta ausente en la teoría de la economía política clásica porque rompe con la problemática ideológica humanista y se sitúa en una problemática científica que sustituye la cuestión ideológica de las garantías del conocimiento, por la cuestión científica de los mecanismos de apropiación cognoscitiva.

Con lo cual se pone de manifiesto que la cuestión crucial del cambio de problemática está vinculada a la reformulación de la naturaleza del pensamiento, que a partir de ahora es -siguiendo a Spinoza- "un aparato de pensamiento, basado y articulado en, la realidad natural y social” (Ibíd.: 47). Pero, además, involucra una reformulación de la práctica, ya que, en el nuevo marco, el concepto de producción consiste en pensar el concepto de la unidad de sus condiciones: el modo de producción.

Ahora bien, cabe preguntarse ¿cuál es en la práctica teórica, la instancia que corresponde a los medios de producción? Desde tal concepción se reconoce que no existe una práctica en general, sino prácticas distintas, cada una con una estructura propia, la de una producción; "concibiendo lo que distingue entre sí estas diferentes estructuras, es decir, la naturaleza diferente del objeto al cual se aplican, de sus medios de producción y de las relaciones en que producen" (Ídem). Siguiendo a Spinoza y su célebre distinción de los géneros, Althusser postula tres Generalidades, con las que trabaja la práctica teórica: el Primer Género es propiamente el mundo vivido en el que reina la imaginación, correspondiente al nivel de la ideología ${ }^{33}$. El Segundo Género son las abstracciones científicas; y el último permite pensar "la esencia singular" (SM: 232). En el esquema althusseriano: la Generalidad I es la materia prima, la Generalidad II: los instrumentos de trabajo teórico; la Generalidad III corresponde al concreto de pensamiento o pensamiento, lo propio de la práctica teórica. El paralelismo quedaría

\footnotetext{
${ }^{33}$ En realidad, no es un tipo de conocimiento, sino "el mundo inmediato tal como nosotros lo percibimos, es decir, vivimos bajo el dominio de la imaginación" (UTM: 135)
} 
entonces así:

1) Primer género de conocimiento/ Generalidad I: corresponde al nivel de "lo imaginario" / la materia prima.

2) Segundo género de conocimiento/ Generalidad II: las abstracciones científicas/los instrumentos de trabajo teórico.

3) Tercer género de conocimiento/ Generalidad III: la "esencia singular" / "lo concreto de pensamiento", lo propio de la práctica teórica.

Althusser sigue a Spinoza cuando este sostiene que "en la vida individual y social no hay más que singularidades (nominalismos) realmente singulares" ${ }^{34}$. Pero que son al mismo tiempo, universales puesto que "esas singularidades están como atravesadas y como habitadas por invariantes repetitivas o por constantes": no por generalidades, sino por constantes repetitivas que se pueden volver a encontrar con sus variaciones singulares en otras singularidades de la misma especie o género (UTM: 136).

Spinoza encuentra, según Althusser, en la historia singular del pueblo judío, una constante que ha tematizado "en general" en el Apéndice del Libro I de la Ética a propósito de la religión en general. Se trata de "un conocimiento y una elucidación de una historia singular: la de un pueblo, el pueblo judío, a la que Spinoza alude como ejemplificación de una constante repetitiva, su teoría de la ideología religiosa, su teoría del lenguaje, su teoría del cuerpo y su teoría de la imaginación..." (Ibíd.: 137). Althusser otorga a esta abstracción el estatuto de lo concreto o de lo vivido, que se encuentra en el primer género de conocimiento, el lugar de lo ideológico.

Lo significativo de la distinción que realiza Spinoza, desde nuestra perspectiva, es que muestra que en el fondo en el "conocimiento del tercer género" no estamos nunca ante un nuevo objeto, sino ante una nueva forma de relación de apropiación (término de Marx) de un objeto que está siempre ya ahí desde el primer género de conocimiento: el mundo (...) "Lo que cambia no es nunca el ser mismo de las cosas, sino la relación de apropiación que el sujeto humano mantiene con ellas" (Ídem.).

\footnotetext{
${ }^{34}$ Althusser señalaba que, si la distinción necesaria entre objeto real y objeto de conocimiento no se asentaba de manera sólida, se caía el riesgo de caer en el nominalismo, el idealismo. "Se cree generalmente que Spinoza ha cedido ante el nominalismo. En todo caso ha tomado precauciones para guardarse del idealismo por mor de su teoría de una sustancia dotada de atributos infinitos, y por el paralelismo de los dos atributos, de extensión y de pensamiento. Marx se guarda también de ello y con más seguridad gracias a la tesis del primado del objeto real sobre el objeto de conocimiento, y por el primado de esta primera tesis sobre la segunda: la distinción entre el objeto real y el objeto de conocimiento (...)" (SM: 236).
} 
Althusser advierte que la realidad pretendida por el conocimiento (del tercer género) no es la de una generalidad, sino la de una singularidad universal (en la que subyace la distinción entre el "concreto real" del concreto de pensamiento). Recordemos que para Althusser, siguiendo a Marx, todo proceso de conocimiento se dirige de lo abstracto a lo concreto, de la generalidad abstracta a la singularidad concreta. Es lo que Althusser llama en "Sobre la dialéctica materialista" el paso de las generalidades I a las generalidades III mediante las generalidades II, las abstracciones.

En esta dirección Althusser afirma que "si hacemos abstracción, provisionalmente, de los hombres, los medios de producción forman la Generalidad II, constituida por el cuerpo de conceptos cuya unidad, más o menos contradictoria, constituye la "teoría" de la ciencia en el momento histórico considerado, "teoría" que define el campo en el que debe plantearse todo "problema" de la ciencia". Así podemos afirmar que "la práctica teórica produce Generalidades III por el trabajo de la Generalidad II sobre la Generalidad I. Althusser señala que, si el empleo de conceptos generales es indispensable a la práctica teórica científica: no es resultado sino su requisito previo. Cuando se desarrolla una ciencia ya constituida, esta trabaja, por lo tanto, sobre una materia prima (Generalidad I) constituida de conceptos todavía ideológicos o de hechos científicos, o de conceptos ya elaborados pero pertenecientes a un estado anterior de la ciencia; la que tendrá como trabajo la transformación de la Generalidad I en Generalidad III, mediante las Generalidades II (RTM: 152).

No obstante, Althusser no dice que las Generalidades II que trabajan sobre las Generalidades I, trabajen únicamente sobre lo ideológico, ya que pueden trabajar también sobre abstracciones ya elaboradas científicamente o sobre ambos grupos. Aunque Althusser aclara que existe el caso límite de una materia prima puramente ideológica, cuya hipótesis le ha permitido plantear la oposición entre ciencia e ideología, y "el corte epistemológico que Spinoza designaba mucho antes de Bachelard, entre el primer y el segundo género y extraer de ello diversos efectos ideológicos, que no se hallaban, como he indicado en mis Elementos de autocrítica, libres de todo teoricismo" (SM: 234).

Efectivamente, de acuerdo con la dialéctica de la práctica teórica, sostiene Althusser, la generalidad abstracta del comienzo y trabajada (Generalidad I) no es la misma que la generalidad que trabaja (Generalidad II) ni que la generalidad específica (Generalidad III). Según la lectura de Althusser, a diferencia de Hegel -que "desconoce las transformaciones cualitativas reales, las discontinuidades esenciales que constituyen 
el proceso mismo de la práctica teórica" (PLC: 156)-; la dialéctica marxista muestra que, no es el concepto (general) de fruta el que produce las frutas (concretas) por autodesarrollo, sino por el contrario las frutas (concretas) son las que producen el concepto de fruta (abstracto)" (Ibíd.: 157). Además de que, el proceso de conocimiento que involucra una posición materialista en epistemología, es un proceso sin sujeto, efecto de estructuras. En esta tesis subyace una tesis de la causalidad estructural, de una estructura que se hace presente a través de sus efectos y que abordaremos a continuación.

\section{Causalidad estructural y causalidad inmanente}

En especial, este concepto supone una primacía ontológica de las relaciones por sobre los elementos (los cuales se configuran relacionalmente).

(Althusser, Para leer El capital)

De acuerdo con lo expuesto, la superestructura ya no puede pensarse como determinada mecánicamente por la estructura económica, sino como su condición de existencia: "la existencia de la estructura en sus efectos" (PLC: 203) 35 . Althusser se pregunta en este sentido: “¿con qué concepto pensar la determinación, sea de un elemento, sea de una estructura, por una estructura?" (Ídem). Este es el mismo problema, dice Althusser, que el que aqueja a Marx cuando formula el concepto de Darstellung- "el concepto epistemológico- clave de toda la teoría marxista del valor, y que precisamente tiene por objeto designar este modo de presencia de la estructura en sus efectos, por lo tanto, la propia causalidad estructural" (Ídem).

Entonces bien, Althusser propone el concepto de causalidad estructural, para referir a una estructura ausente que se manifiesta en sus efectos, prevenido por Macherey de no utilizar el término de estructura "latente" porque este puede ser interpretado como una estructura "escondida" que hay que develar ${ }^{36}$. En este marco, ¿qué significa que la estructura se haga presente a través de sus efectos? Para Althusser "la ausencia de la causa en la "causalidad metonímica" de la estructura sobre sus efectos

\footnotetext{
35 Según Milner (2003) esta concepción de la estructura postulada por Althusser, lo distancia de las interpretaciones estructuralistas más rígidas, características de los '60 que seguían un programa "irremediablemente conservador en cuanto a la ciencia ideal. Un discurso, para ser una ciencia, debe cumplir al menos ciertas condiciones formales: unicidad y especificidad del objeto, minimalismo de los axiomas y conceptos fundamentales" (p. 231).

${ }^{36}$ En diálogo con el psicoanálisis, también Lacan rechaza la idea de develamiento, al proponer que el inconsciente es algo otro que un repositorio oculto de significado. Cfr. Montag, 2018.
} 
no es el resultado de la exterioridad de la estructura en relación a los fenómenos económicos; es, al contrario, la forma misma de la interioridad de la estructura como estructura, en sus efectos" (PLC: 204). La causalidad estructural o metonímica implica reconocer que la relación entre estructura y superestructura no corresponde a una causalidad lineal transitiva, ni tampoco a una relación de expresión, sino que se trata de una causa ausente que solo existe o se hace presente en sus efectos.

Este tipo de causalidad, remite a la causalidad inmanente de Spinoza que muestra que la naturaleza Naturada (efecto) es "tan Dios" (o sustancia) como la Naturaleza Naturante (causa). No se trata de una causalidad trascendente, tampoco transitiva (como en Descartes, según Althusser) ni expresiva (Leibniz). Sino que hay una relación de inmanencia entre causas y efectos; y no hay una "jerarquía” de los seres con una esencia o causa última que esté "más allá" de sus efectos (E, I, prop. 29). Desde la mirada althusseriana, este tipo de causalidad es capaz de dar cuenta de la eficacia del todo sobre sus partes y de la acción de las partes en el todo; "un todo sin clausuras, que no sea sino la relación activa de sus partes" (EA: 54).

De esta manera, la causalidad estructural en el marco de la teoría marxista de las formaciones sociales, permite comprender a las formaciones sociales como un todo complejo estructurado con dominante, cuya unidad está constituida por un tipo específico de complejidad que pone en juego las distintas instancias, que están determinadas en última instancia por la economía. En este marco, la relación de producción se articula e interacciona con otras relaciones, ya que la formación social capitalista no se reduce tan sólo a la relación de producción capitalista, esto es, a su infraestructura. Sino que lo superestructural - donde se encuentra la ideología- es tanto causa como efecto de la base económica, es pensado simultáneamente en su especificidad (índices de eficacia propia) y en su relación íntima con la estructura; por tanto, formando parte de las condiciones de existencia de la estructura material. Así, mientras que en Para leer El capital, por ejemplo, son las relaciones de producción las que determinan el lugar y el rol que deben ocupar los agentes de la producción; en Ideología y aparatos..., es la interpelación ideológica la encargada de determinar el lugar que ocuparán los individuos siempre ya sujetos. Allí, los efectos de la economía sobre las esferas de la ideología deben ser pensados a la vez como causas y como efectos, como condiciones de su reproducción.

Una vez desarrolladas las características centrales de la causalidad estructural, nos interesa enfatizar que existe una transversalidad de la causalidad estructural en el 
corpus althusseriano, ya que el concepto no se limita a su aparición en Para leer El capital, sino que atraviesa los análisis posteriores de Althusser sobre la ideología y la reproducción en su integralidad, tal como como ocurre en Ideología y aparatos. Así como incluye las teorizaciones de "el último Althusser", como examinaremos hacia el final de esta primera parte. Al enfatizar esta transversalidad de la tesis de la causalidad estructural en la obra integral de Althusser, lo que pretendemos es objetar aquellas lecturas que proponen un giro (Kehre) al interior de la obra althusseriana.

Entonces bien, con la formulación de la causalidad estructural, se comprende que la explotación de clases en el marco de las relaciones de producción capitalistas no puede permanecer sin el auxilio de la superestructura, sin las relaciones jurídicopolíticas, y las relaciones ideológicas, que son determinadas en última instancia por las relaciones de producción. Pero, ¿cómo se articula esta instancia superestructural con la estructura económica? Será necesario que exploremos la concepción de la determinación en última instancia.

\section{La determinación en última instancia}

la tópica marxista ofrece a quien la interroga la indicación de su lugar en el proceso histórico: he aqui el lugar que tú ocupas y he aqui donde debes desplazarte para cambiar las cosas (...) pero este lugar no es un punto fijo y no está fijo, es un sistema articulado de posiciones regido por la determinación en última instancia. (Althusser, Defensa de Tesis de Amiens)

Ya hemos señalado que para Althusser el método dialéctico que se encuentra en las obras de madurez de Marx es un método completamente nuevo, que nace a partir de la "ruptura" que se comienza a efectuar en el pensamiento de Marx -en el que este cambia de terreno, o si se quiere, de elemento: jen lugar de pelear por tierra, pelead por mar!" (MDL: 42)- a partir de $1845^{37}$.

De acuerdo con la lectura de Althusser, la ruptura teórica de Marx "estalla" con la confrontación entre la concepción feuerbachiana de la alienación, y los conceptos de la economía política burguesa. Por lo cual, la ruptura realizada por Marx tendría dos

37 Para Althusser, se trata de un momento de ruptura que emerge tras los Manuscritos de 1844, que a pesar de haber sido leídos como una forma renacida de humanismo a partir de 1930 con lecturas de corte "socialdemócrata"- que pretendían "alcanzar lo real casando la filosofia idealista de la alienación feuerbachiana hegelianizada con la ideología mítica de una economía política adoptada sin crítica" (MDL: 42). Pero, Althusser ha insistido en valorizarlos como textos de "ruptura" con la ideología humanista- feuerbachiana. 
dimensiones: la primera, concierne a la relación entre los términos e indica una distancia en el modo de concebir la dialéctica; la segunda concierne a los términos mismos y se vincula con la concepción de la sociedad y de la historia.

En efecto, Marx, bajo la lectura althusseriana, no sólo habría transformado la concepción de la dialéctica, sino que además habría invertido los términos del modelo hegeliano: la sociedad civil y el Estado, sustituyéndolos por la estructura y la superestructura, respectivamente. El primero designando la base económica de la sociedad (fuerzas productivas, relaciones de producción), y el segundo término designando el Estado y todas las formas jurídicas, políticas e ideológicas. Pero Althusser aclara que no debe entenderse a la superestructura como epifenómeno de la estructura porque a partir de ahora se concibe de manera nueva la relación de las instancias determinantes en el complejo estructura- superestructura de una formación social, que se ilustra en la siguiente cita:

(...) ¿toda sociedad histórica no está acaso constituida por una infinidad de determinaciones concretas, de las leyes políticas a la religión, pasando por las costumbres, los usos, los regímenes financiero, comercial, económico, el sistema de educación, las artes, la filosofía, etc.? (...) Estas determinaciones provienen de los elementos que forman la vida concreta de un mundo histórico (instituciones económicas, sociales, políticas, jurídicas, costumbres, moral, arte, religión, filosofía, y hasta los acontecimientos históricos: guerras, batallas, derrotas, etc.).

La formación social comprendida como un todo complejo sobredeterminado, tendrá una autonomía relativa de las superestructuras, las que ejercerán una eficacia específica sobre la estructura, con lo cual se produce la determinación de una estructura por otra estructura (sobredeterminación); disipando así las interpretaciones mecanicistas. De acuerdo con la lectura althusseriana, la Tópica espacial de Marx representa su concepción de la sociedad como un todo complejo estructurado con dominante, donde la base (die Basis) es la economía, la unidad de las fuerzas productivas y de las relaciones de producción; sobre la que se eleva la planta o las plantas de la superestructura jurídico- política e ideológica (Überbau). En el marco de esta metáfora espacial -que subvierte según Althusser, el orden hegeliano- si bien el Estado se encuentra siempre en la superestructura, el derecho deja de ser omnipresente y 
la economía, la infraestructura, es la que determina en última instancia a las otras instancias. Tal como da cuenta en Elementos de autocrítica:

Por este hecho, la relación entre la infraestructura y la superestructura deja de tener algo que ver con la relación hegeliana: "verdad de...". El Estado permanece "arriba" pero no como "la verdad de" la economía: al contrario de una relación de "verdad" ejerce una relación de mistificación fundada en la explotación garantizada por la fuerza y la ideología. La conclusión está clara: la posición de la Tópica marxista impide a la dialéctica el delirio idealista de producir su propia materia: le impone, al contrario, el reconocimiento forzado de las condiciones materiales de su eficacia. Estas condiciones conciernen a la definición de los lugares (de las “esferas") a sus límites, a su modo de determinación en la "totalidad" de una formación social. Para pensar estas realidades, la dialéctica materialista no puede contentarse con las formas residuales de la dialéctica hegeliana. Le son necesarias otras nuevas formas inencontrables en la dialéctica hegeliana.

En el marco de la contradicción marxista existen múltiples instancias sobredeterminadas $^{38}$ : ideología, política, economía, entre las cuales no se establecen relaciones de causalidad mecánica, sino relaciones de causalidad estructural, es decir: todas las instancias coexisten, porque son irreductibles entre sí. Entre estas diversas instancias, la económica tiene un papel dominante sobre las demás, pero esto no ocurre porque actúe de manera directa sobre las relaciones políticas que se reflejarían, a su vez, en la ideología, como sostendría un análisis "economicista". Sino que la sociedad, que es un todo complejo articulado le asigna a esa instancia un papel dominante: un todo complejo con dominante. Este todo complejo, determinado en última instancia por la lucha de clases económica, constituye una demarcación elemental con la totalidad hegeliana en la que las prácticas no son diferenciadas.

En efecto, en esta estructura compleja y articulada, las distintas instancias son "relativamente autónomas" y se articulan según modos de determinación específicos, fijados, en última instancia, por la instancia de la economía (RTM: 71). De manera que la estructura del todo está articulada como la estructura de un "todo orgánico jerarquizado" (ídem) y esta jerarquía es la jerarquía de la eficacia de una estructura

${ }^{38}$ Como anticipamos, el concepto de sobredeterminación es tomado del psicoanálisis, y es utilizado según afirma el propio Althusser, para dar cuenta de "la determinación de una estructura por otra estructura, y de los elementos de una estructura subordinada por la estructura dominante" (PLC: 203). 
dominante sobre las estructuras subordinadas y sus elementos.

Ahora bien, que la economía sea dominante no implica que explique el todo, porque la contradicción dominante está sobredeterminada por las contradicciones de las otras instancias. Se trata de una acumulación de contradicciones, donde "las diferencias que constituyen cada una de las instancias en juego al fundirse en una unidad real no se 'disipan' como un puro fenómeno en la unidad interior de una contradicción simple" sino que la unidad que constituyen con esta "fusión" de ruptura revolucionaria, la constituyen con su esencia y su eficacia propias (Ibíd.: 81). De lo anterior se desprende que, la contradicción es inseparable de la estructura del cuerpo social todo entero, en el que ella actúa inseparable de las condiciones formales de su existencia y de las instancias mismas que gobierna; que ella misma es afectada en lo más profundo de su ser por dichas instancias, determinante pero también determinada por los distintos niveles y las diversas instancias de la formación social que ella anima" (Ídem). De modo que, es la estructura -la manera en que las instancias se combinan entre sí- la que decide en última instancia (no totalmente) cuál es la instancia que dominará sobre las otras. De manera análoga "de acuerdo con la concepción materialista de la historia, el factor determinante en la historia es, en última instancia, la producción y la reproducción de la vida real" 39 .

Entonces bien, la sobredeterminación, no es simplemente la adición a una contradicción existente porque "el desarrollo es desigual" (SM: 230). Si fuese un desarrollo denominado igual, se podría hacer una mera sumatoria, pero no es el caso. La contradicción sobredeterminada, tal como se encuentra en El capital, se caracteriza según Althusser- por poner en juego contrarios que se hallan en una relación de desigualdad, y que reproducen sin cesar sus condiciones de existencia por la realidad misma de la contradicción. Se trata de un tipo de determinación estructural por la cual las variaciones de una formación social no son comprendidas como accidentales, producidas por condiciones exteriores sobre un todo estructurado fijo; sino más bien como reestructuraciones concretas inscritas en el juego de articulaciones entre las contradicciones de la estructura, que son siempre, múltiples e imbricadas. Con lo cual, el concepto de sobredeterminación supone una primacía ontológica de las relaciones por sobre los elementos.

De acuerdo con la lectura althusseriana, en la Introducción de 1857 Marx

\footnotetext{
${ }^{39}$ Engels, F. Carta a Boch en Ludwig Feuerbach y el fin de la filosofia clásica alemana. Cfr. SM: 223.
} 
precisaría que la estructura del todo debe ser concebida como un todo diferenciado, como un complejo jerarquizado y articulado (Gliederung) con múltiples instancias, diferenciadas y determinadas en última instancia por las relaciones económicas.

La economía entonces, fija la diferencia real de las otras instancias - "aquellas que figuran en la superestructura jurídico- política e ideológica" (PLC: 109)- su autonomía relativa y su propio modo de eficacia sobre la propia base. En este sentido, frente a las críticas al mecanicismo de Marx, la determinación en última instancia tiene una doble función: desmarca radicalmente a Marx de toda concepción mecanicista del determinismo y permite adoptar una posición dialéctica que se desmarca de todas las filosofías idealistas de la historia. Precisamente, cuando Marx inscribe la dialéctica en el juego entre las instancias de una tópica, toma distancia de la ilusión de una dialéctica que sería capaz de producir, por el movimiento espontáneo de su autodesarrollo, su propia materia. Sino que, al someter la dialéctica a la constricción de la tópica, Marx "le prescribe que sea materialista, por consiguiente, que reconozca que sus propias figuras son prescritas por la materialidad de sus condiciones" (SM: 224).

\section{La dialéctica marxista}

...La dialéctica es la ley de la transformación, del devenir de los procesos reales (tanto de los procesos naturales y sociales como de los procesos del conocimiento). Es en este sentido que la dialéctica marxista no puede ser sino materialismo, pues no expresa la ley de un

puro proceso imaginario o pensado, sino la ley de los procesos reales, que son ciertamente distintos y "relativamente autónomos", pero que están todos fundados en última instancia en los procesos de la naturaleza material. (Althusser, La filosofía como arma de la revolución)

De acuerdo con la posición de Althusser en su Defensa de tesis en la Universidad de Amiens el rodeo por Spinoza le permite pensar en la negación de la negación, la Aufhebung, la superación que conserva lo que supera. Permitiendo pensar en la "mistificación de la dialéctica hegeliana" (SM: 196).

Para Althusser, la cuestión de la dialéctica marxista únicamente puede plantearse si la dialéctica se somete al primado del materialismo que rompe con toda filosofía del Origen del Ser, del Sujeto o del Sentido; puesto que "cuando se rechaza el origen radical de las cosas, cualquiera que sea su figura, es preciso forjar de veras categorías totalmente distintas de las categorías clásicas para pensar delegaciones de origen que son la esencia, la causa o la libertad" (Ibíd.: 226). Dicho todo esto, ¿qué es entonces lo 
que toma prestado Marx de Hegel? Si la dialéctica hegeliana recusa de todo Origen (que se manifiesta en la Lógica, señala Althusser, donde el Ser es idéntico a la Nada) esa misma dialéctica la proyecta en el Fin de un Telos, que hace de su propio proceso su propio Origen, su propio Sujeto. De manera que no hay Origen en Hegel, pero a condición de que "el proceso en su conjunto, consumado en la totalidad final, es en sí mismo, indefinidamente, en todos los momentos que anticipan su fin, su propio Origen" (Ídem). De modo análogo: "No hay Sujeto en Hegel, pero ello es así porque el devenirSujeto de la sustancia, como proceso consumado de negación de la negación, es el Sujeto del proceso mismo" (Ibíd.: 227).

Analizando comparativamente Althusser señala que "Hegel piensa la sociedad como una totalidad", mientras que Marx la piensa como "un todo complejo estructurado". A Hegel le concede la categoría de totalidad, y a Marx la de todo. No se trata simplemente de una divagación verbal, sino que refiere a una diferencia sustancial entre ambos: para Hegel, la sociedad, al igual que la historia, son "círculos de círculos, esferas de esferas" (Ídem). Sobre toda su concepción reina una idea de totalidad expresiva en la que todos los elementos son partes totales, en la que cada parte expresa la unidad interna de la totalidad que es la "objetivación- alienación de un principio simple" (Ídem.) ${ }^{40}$. De manera análoga en "El objeto de El Capital", Althusser señala que la totalidad hegeliana,

...posee un tipo de unidad tal que cada elemento del todo, ya se trate de tal determinación material o económica, de tal institución política, de tal forma religiosa o artística

o filosófica, no es jamás sino la presencia del concepto a sí mismo en un momento histórico determinado. Es en este sentido que la co-presencia de los elementos los unos con los otros y la presencia de cada elemento del todo están fundadas en una presencia previa en derecho: la presencia total del concepto en todas las determinaciones de su existencia.

En el marco de la totalidad hegeliana, lo real es el concepto y, por tanto, la complejidad de lo real puede ser subsumida en la generalidad del concepto. La presencia del concepto se expresa en todas las dimensiones de la vida social, constituyendo una totalidad homogénea en la que las realidades y las prácticas -que son

\footnotetext{
40 Retomando de Montesquieu la idea de que en una totalidad histórica todas las determinaciones concretas, sean ellas económicas, políticas o morales, expresan un único y mismo principio.
} 
indistinguibles entre sí- son reductibles al concepto y susceptibles de ser comprendidas y explicadas por su remisión a este. Pero para Marx, las diferencias son reales y no son únicamente diferencias de esferas de actividad, de prácticas, de objetos: "se trata de diferencias de eficacia" (SM: 228).

En este sentido, advierte Althusser, "no es casual que Marx abandone la metáfora del círculo y opte por la de un edificio. Un círculo está cerrado, y la noción de totalidad que le conviene, supone que pueden abrazarse exhaustivamente todos los fenómenos para reunirlos en la unidad simple de su centro" (Ídem). Marx adopta la metáfora del edificio en la que sólo se dice "que es preciso distinguir, que las distinciones son reales, irreductibles, que, en el orden de la determinación, la parte no es igual entre la base y la superestructura, y que esta desigualdad dotada de instancia dominante es constitutiva de la unidad del todo" (Ídem).

El argumento de Althusser entonces, de por qué en Marx se trata de un todo, es porque el todo marxista es complejo y desigual. En la concepción marxista de una formación social todo se sostiene, "la independencia de un elemento es siempre la forma de su dependencia, y el juego de las diferencias se halla regido por la unidad de una determinación en última instancia" (Ídem). Como ya se ha dicho, lo que es determinante en última instancia es la lucha de clases económica, prolongada en la lucha de clases política por la toma del poder del Estado, y he aquí cómo la lucha de clases de la base se articula (o no se articula) con la lucha de clases de la superestructura.

Finalmente, Althusser señala que insiste sobre la "última instancia", sobre "el todo estructurado con instancia dominante", "sobre la sobredeterminación", "sobre la desigualdad de la contradicción”, porque tenía la pretensión, ante todo, de reconocer y de señalar el lugar y la función de la teoría del movimiento obrero marxista. No sólo para reivindicar la tesis de Lenin de acuerdo con la cual "sin teoría revolucionaria no hay movimiento revolucionario"; sino además para pensar con firmeza la relación entre una teoría y su práctica, atendiendo al hecho de que "las revoluciones conocidas son o prematuras o abortadas, en una teoría que se las arregla sin la normatividad, entonces resulta evidente que algo no resulta del lado de su dialéctica (...)” (Ibíd.: 231).

Hasta aquí entonces: en la lectura de Althusser, el todo marxista es una unidad compleja, estructurada a partir de la conexión compleja de los diferentes niveles que la conforman, externos los unos a los otros, y relativamente autónomos entre sí. En la que resuena aquella frase de la Introducción del '57: "lo concreto es la síntesis de múltiples determinaciones, de las relaciones en las cuales están prisioneros y participantes “(...) 
Marx no parte del hombre que es una idea vacía (...)”.

Ahora bien, hay que decir que, la lectura de Althusser también rechaza una cierta visión de la teoría marxista, según la cual esta "englobaría" la totalidad de los procesos que conducirían del capitalismo al comunismo, como señala en El marxismo como teoría finita: "cuando en realidad ella designa únicamente las tendencias contradictorias que operan en el proceso actual" (Ibíd.: 303). Para Althusser, Marx piensa el comunismo como una tendencia de la sociedad capitalista. Pero no se trata de algo abstracto, sino que ya existe concretamente "en los intersticios de la sociedad esclavista o feudal", en todas las asociaciones que logran escapar, en la medida en que ello es realmente posible, de las relaciones mercantiles.

Es por ello por lo que Althusser plantea una cuestión teórica fundamental: "la teoría marxista es finita y limitada. Se limita al análisis del modo de producción capitalista, y de su tendencia contradictoria" (Ibíd.: 304). Esto abre la posibilidad "de la transición hacia la abolición del capitalismo y su sustitución por otro tipo de sociedad. Sin embargo, Althusser señala que,

Todo lo que se dice de la transición no puede tratarse sino como indicaciones inducidas por una tendencia actual que, como toda tendencia en Marx, se halla "contrarrestada" y puede no verificarse, a menos que la lucha de clases política la haga realidad. Esta realidad no puede preverse desde ahora en su forma positiva determinada: las formas posibles únicamente pueden materializarse e inscribirse en el orden del día, descubrirse y convertirse en realidad, en el curso de la lucha.

(SM: 304)

La teoría marxista es una teoría "finita" sostiene Althusser, y sólo a partir de la conciencia aguda de su finitud es posible plantear la mayor parte de problemas. En ese sentido enfatiza que: "la teoría marxista no dice casi nada ni sobre el Estado, ni sobre la ideología y las ideologías, ni sobre la política ni sobre las organizaciones de la lucha de clases (su estructura, su funcionamiento)" (Ibíd.: 305). Que la teoría marxista sea una teoría finita, implica que esta se encuentra desbordada por la política, que existe un desajuste entre la teoría y la política, un exceso de la práctica política en relación con la teoría. Es a partir de este desajuste, y de esta finitud de la teoría marxista, que la dimensión de la política se torna un objeto pensable. Esta cuestión se relaciona estrechamente con la propuesta de una nueva práctica de la filosofía, de una filosofía 
inmanente a la coyuntura, a sus conflictos, por ende, inherentemente política.

Althusser "ve" a Maquiavelo como un referente de esta propuesta de práctica filosófica, como "el primer teórico de las coyunturas, aquel que reflexiona en la coyuntura, dentro de y no sobre la coyuntura" (PLC: 56). Que lo hace en torno a una coyuntura singular: la de la unidad nacional italiana. Maquiavelo, según Althusser, detectaría que los problemas que se manifiestan en Italia no son la mera indicación de un problema sino un espacio sobredeterminado, con múltiples determinaciones, con ritmos y eficacias diferenciales, además de prácticas que habitan diversos tiempos.

Ahora bien, reflexionar filosóficamente sobre la coyuntura política -puesto que la filosofía es una forma de existencia original de la teoría, "vuelta por entero hacia la práctica, que puede tener una verdadera autonomía si su relación con la práctica política está constantemente controlada por los conocimientos producidos por la ciencia marxista" (IF: 232)-implica reclamar una teoría que "esté a la altura" de las complejidades de la coyuntura. En otras palabras, que no subsuma los casos singulares en la universalidad del concepto; sino que sea capaz de leer esa trama de relaciones y determinaciones en su complejidad irreductible. Esta cuestión forma parte, de un elemento central de la intervención materialista althusseriana: su propuesta de una nueva práctica de la filosofía, que exploraremos a continuación. 


\section{Capítulo III. La filosofía como lucha de clases en la teoría}

El capital era el más peligroso misil jamás lanzado a la cabeza de la burguesía.

(Cfr. Althusser, Marx dentro de sus límites)

De acuerdo con la lectura filosófica de Althusser existe una ruptura teórica en el pensamiento de Marx entre una problemática ideológica y una problemática científica. Esta demarcación que Althusser "ve" en la obra de Marx, y su formulación de una práctica teórica, han sido criticadas por reinstaurar un positivismo y un teoricismo.

El propio Althusser reconoce esta tendencia en sus textos de autocrítica- en los que, sin embargo, reafirma la tesis del antihumanismo teórico, y su concepción de la historia como un proceso sin sujeto- lo cual implicó reconocer la predominancia de la lucha de clases, y la propuesta de una práctica filosófica como lucha de clases en la teoría. Hacia el final de este capítulo mostraremos que la primacía de la lucha de clases y el rechazo materialista al supuesto de un sujeto-centro toman una forma precisa en las formulaciones althusserianas del materialismo aleatorio.

Examinar su rectificación del teoricismo, y su propuesta de una nueva práctica filosófica; así como examinar la primacía de la lucha de clases y la transversalidad de tesis materialistas fundamentales, en la propuesta de un materialismo aleatorio; constituyen el objetivo principal de este capítulo. 


\section{La autocrítica de Althusser}

al reducir y concretar la "ruptura" a esta sola oposición, incluso recurrente, incluso "continuada", incluso "sin fin", entre la ciencia y la ideología, adoptaba sin crítica el punto de vista de la "ciencia” en sí misma (iy no sólo en sí misma, evidentemente!); o mejor - puesto que esta fórmula es todavía el punto de vista de los "agentes" de la práctica cientifica acerca de su propia práctica y la historia de sus resultados...

(Althusser, Elementos de autocrítica)

El énfasis que Althusser coloca en el carácter científico del materialismo histórico junto a la propuesta de una Teoría de la práctica teórica, ha llevado a que su propuesta sea ampliamente criticada por "teoricista" y "cientificista" al interpretarse que desplazaba sobre la pareja de la práctica y la ideología la oposición abstracta (racionalista) "que opone la verdad al error" (EA: 12). Sin embargo, Balibar sostiene que la tesis de Althusser sería justamente la inversa: la propia teoría es una práctica, una forma de la práctica entre otras, necesariamente social, necesariamente vinculada a todas las demás prácticas sociales.

En la misma dirección, la propuesta de una "ciencia de la ciencia", llamada "Teoría" (Lecourt, 1987: 17; y Balibar, 2004: 23) le habría costado al planteo althusseriano, quedar atrapado en el dilema de una "esencia de la ciencia", objeto de una teoría general, indistinguible de una teoría del conocimiento con la que tanto polemizó Althusser. La propuesta althusseriana se encontraría entrampada así, en el callejón sin salida de una "garantía" especular (que él mismo critica a propósito de la epistemología empirista) ya que, para poder pensar el corte epistemológico de Marx, le es preciso anticipar su forma, invocando otros cortes de manera que esos ejemplos- garantes de cientificidad- se constituyen en modelos (PLC: 21).

Si consideramos como invita a hacerlo Pedro Karczmarczyk (2016a) a reconocer que existen rupturas epistemológicas diversas, el teoricismo se disipa y se desestabiliza. Lo que implica también reconocer que existen condiciones de existencia diversificadas para la ruptura epistemológica que dependen de "si la disciplina científica creada rompe con una ideología cuyo ámbito de aplicación son los medios de producción, la fuerza de trabajo o las relaciones de producción" (Karczmarczyk, 2016a: 99).

Balibar señala que el corte epistemológico no se produce con la ideología en general, sino con una ideología en particular: la burguesa dominante. Por ello, siguiendo esta línea "resulta imposible discutir el concepto de corte sin tener en cuenta la 
definición del concepto de historia (para lo cual la referencia en Para leer El capital de un 'esbozo del tiempo histórico' es vital)” (Balibar, 2004: 25).

Ahora bien, el propio Althusser reconoce esta desviación teoricista en sus textos de autocrítica elaborados entre 1970 y 1975. El inicio de estas rectificaciones comienza con la segunda edición de La revolución teórica de Marx; le sigue Lenin y la filosofía; luego Para una crítica de la práctica teórica. Respuesta a John Lewis; La Filosofía como arma de la revolución y Elementos de autocrítica. A estos textos se le suma un texto póstumo que ilumina y potencia las rectificaciones que Althusser hace en este periodo, se trata de la Defensa de Tesis de Amiens donde Althusser profundiza su rectificación y bosqueja un balance y una síntesis de su trayectoria teórica. Pero, la rectificación no implica, sin embargo, que desaparezca de una vez y para siempre la relación entre ciencia e ideología, sino que está atravesada ahora por la distinción entre ideologías teóricas e ideologías prácticas que se configura a partir de la segunda edición de La Revolución teórica de Marx, donde se distingue las teorías y prácticas teóricas; de las prácticas sociales y formaciones sociales.

En esta misma dirección, A propósito de la naturaleza de los cortes epistemológicos, Althusser precisa que estos son "específicos e irreductibles a un proceso uniforme de la práctica teórica” (PLC: 43). Y afirma que, si él (Althusser) había reducido la "ruptura" a una simple oposición racionalista especulativa "¡la mayoría de sus críticos, la reducen a nada!" (Ibíd.: 14). Como John Lewis que se refiere a esta como una invención pura y simple. Pero, para Althusser es innegable que en la historia del pensamiento teórico de Marx existe algo parecido a una "ruptura".

Recordemos que Althusser caracteriza al corte como un acontecimiento producido por una conjunción de causas históricas (teóricas y no teóricas), cuyo encuentro será un resultado nuevo: irreversible e ininterrumpido. Pero el corte, no es sólo un acontecimiento, sino también un proceso "de un comienzo que no tendrá fin": de una tendencia a la fusión de esa teoría con el movimiento obrero (tal como aparece en otras obras posteriores) y que es interiormente contradictorio y sobredeterminado.

Entonces bien, en sus "textos de autocrítica", Althusser rectifica su teoricismo y reformula sus posiciones en torno a: a) la naturaleza del corte epistemológico, b) la distinción entre ciencia/ ideología y c) el vínculo orgánico de la práctica y la teoría. Nuestra hipótesis es que, estas retracciones althusserianas, están vinculadas con la entrada en escena de una dimensión que estaba ausente: la política que posibilita rectificar sus posiciones, como se manifiesta, por ejemplo, en las siguientes citas: 
Había advertido la existencia de la ruptura, pero, al pensar en ella bajo el enmascaramiento marxista del error en ideología, y pese a toda la historia y la dialéctica que pretendía inyectarle en categorías que era, en última instancia, racionalistas, no podía explicar lo que exigía este corte, y si en el fondo lo intuí, incapaz de pensarlo y de explicarlo.

...Pretendía defender al marxismo contra las amenazas reales de la ideología burguesa: era preciso mostrar su novedad revolucionaria (...) pero en vez de dar a este hecho histórico toda su dimensión social, política, ideológica y teórica, lo reduje a las dimensiones de un hecho teórico limitado: la "ruptura epistemológica" observable en las obras de Marx a partir de 1845. Obrando así, me aboqué a una interpretación racionalista de la ruptura oponiendo la verdad al error bajo las especies de la oposición especulativa de la ciencia y de la ideología, dentro de la cual el antagonismo del marxismo y de la ideología burguesa no sería sino un caso particular...

Efectivamente, he dejado de entender en mis primeros ensayos que luego del "corte epistemológico" de 1845 (luego del descubrimiento por el cual Marx funda la ciencia de la historia), categorías filosóficas como alienación y negación de la negación (entre otras) desaparecían. John Lewis me responde que eso no es verdad. Y tiene razón. Se encuentran por cierto esos conceptos (directa o indirectamente) en La ideología alemana, en los Gründisse (dos textos no publicados por Marx) y también, pero más raramente (alienación) y mucho más raramente (negación de la negación: una vez explícitamente) en El capital. (PPT: 55)

En este sentido, en Para una crítica de la práctica teórica frente a la posición humanista e idealista de John Lewis para quien "los hombres hacen la historia" (PPT: 29), Althusser sostiene que "las masas hacen la historia" (Ídem. La cursiva es nuestra). De manera análoga, en la segunda edición de La revolución teórica de Marx Althusser señala que la práctica política "produce transformaciones que no son conocimientos, sino una revolución en las relaciones sociales" (RTM: 144). Lo que es ilustrado con el ejemplo de la lucha de clases durante la Revolución del 17, sobre las que reflexiona Lenin y en las que -según Althusser- "encontramos sin duda la dialéctica marxista en su especificidad" (Ídem.). 
Entonces bien, reconocer el error de contraponer la práctica a la ideología, ha llevado a Althusser a reconocer un problema real ausente: el de la politicidad de la práctica teórica, del que da cuenta el propio autor cuando reconoce que había utilizado una concepción de filosofía que no da cuenta de la relación orgánica que tiene con la política:

He sostenido y he escrito que "la teoría es una práctica" y he arriesgado la categoría de práctica teórica ante el escándalo de algunos. Ahora bien, a esta tesis, como a cada tesis, era necesario considerarla en sus efectos de demarcación, es decir de posición en la oposición. Ante todo, y contra todo pragmatismo, tenía por efecto autorizar la tesis de la autonomía relativa de la teoría, en consecuencia, el derecho para la teoría marxista a no ser tratada como una sirvienta al servicio de las decisiones políticas del presente, sino a desarrollarse, en unión con la práctica política y las otras prácticas sin renunciar a sus propias exigencias. También tenía como efecto, contra el idealismo de la teoría pura, marcar la teoría del materialismo con el sello de la práctica. Otra formulación radical: el carácter interno a la práctica teórica de sus criterios de validación. Podía citar a Lenin, cuando enuncia, entre tantas otras, una tesis provocadora: "La teoría de Marx es todopoderosa porque es verdadera" (No es porque está verificada por sus éxitos y sus fracasos que es verdadera, sino porque es verdadera es verificable por aquellos y estos).

(SM: 216-217)

A partir de su concepción rectificada de la práctica teórica ${ }^{41}$, la filosofía puede efectuar estas transformaciones en las concepciones del mundo, porque "Hasta en sus largos trabajos más abstractos, más difíciles, combate al mismo tiempo por palabras: contra las palabras falsas, contra las palabras equívocas, y en favor de las palabras justas (...) Este combate filosófico entre palabras es una parte del combate político" (FAR: 21).

De esta manera, la teoría interviene directamente en la lucha de clases, en la dimensión política, al desatar una lucha por el sentido de las palabras. Más precisamente, la filosofía "no deja nunca de ser el lugar de una discusión y de un

\footnotetext{
${ }^{41}$ Balibar en su "Prefacio" de Raza, nación y clase (1988) que desde principios de los años '70 a raíz de las discusiones que provocó la lectura estructuralista de EC y precisamente "para escapar de las aporías clásicas de la periodización, reconocí la necesidad de situar el análisis de la lucha de clases y de sus efectos basándome en el desarrollo del capitalismo en el marco de las formaciones sociales" (p. 12).
} 
combate donde resuena, sorda o brutalmente, el ruido y las sacudidas de las luchas políticas y sociales de la humanidad" (RTM: 123). Ello cobra total sentido cuando la filosofía es repensada como Kampfplatz porque:

...si la filosofía es en última instancia lucha de clases en la teoría, la política que constituye la filosofía (como la filosofía que sostiene el pensamiento de los políticos) no se identifica con tal episodio de la lucha política, ni siquiera tampoco con las tomas de partido político de los autores. La política que constituye la filosofía trata y gira en torno a una cuestión muy distinta: la de la hegemonía ideológica de la clase dominante, ya se trate de constituirla, de fortalecerla, de defenderla o de combatirla.

(SM: 214)

Lo cual adquiere total sentido si recordamos que Althusser ya desde la década del '60, establecía que la tarea era constituir una filosofía nueva que se corresponda al continente Historia descubierto por Marx, teniendo en cuenta que: "el texto de la Historia no es un texto donde habla una voz (Logos) sino inaudible e ilegible anotación de los efectos de una estructura de estructuras" (PLC: 22).

En este nuevo marco, centrado en los procesos sociales e históricos concretos, la tesis del proceso sin sujeto permite pensar la acción en la historia, al margen de la idea del individuo de necesidades propio de la economía política clásica, criticada por Marx; y el sujeto de la razón, fundamento filosófico de la tradición del marxismo humanista heredero de la problemática feuerbachiana" (Ibíd.: 110). En contraposición a la subjetividad moderna, el análisis althusseriano advierte que existe una relación necesaria entre el sujeto y la ideología, cuya estructura de la interpelación- garantía es la que produce el efecto de subjetividad ideológica, como examinaremos en la II parte de este trabajo. Este "sujeto", como veremos luego, está ausente del discurso científico, pero con una ausencia determinada que es permanentemente indispensable para la producción de este discurso.

Efectivamente, la identificación del carácter ideológico de la noción de sujeto, parte ahora de la pregunta por sus efectos políticos, redoblando así, la perspectiva histórica ya que involucra la tesis de que "la lucha de clases es el motor de la historia" (EA: 34), lo cual representa un posicionamiento materialista fundamental, que rompe con la categoría del Sujeto como Origen, Esencia y Causa, responsable de su interioridad de todas las determinaciones del "Objeto" exterior" (Ibíd.: 77).De modo similar al de Marx cuando afirma que la "producción crea al consumidor" (I: 12), 
Althusser sostiene que no existe un sujeto fundante de la realidad- tal como supone la filosofía idealista - sino que el sujeto deviene como tal en el proceso de la historia humana, sin sujeto. Y el motor de la historia es la lucha de clases.

La tesis del proceso sin sujeto, se dirige contra la tesis empirista y contra el idealismo de las categorías de Sujeto como Origen, Esencia y Causa, responsable de su interioridad de todas las determinaciones del Objeto externo cuyo sujeto interno se llama" (PLC: 30).Este idealismo acecha, bajo la lectura althusseriana, tanto a la filosofía de Hegel como a la del joven Marx, ya que ambos compartirían la concepción básica de la historia como un proceso generado por las contradicciones que le son internas. Sin embargo, en Marx la dialéctica es sobredeterminada como hemos analizado.

Ahora bien, la lucha de clases no es, comprendida por Althusser como el efecto derivado de la existencia de las clases, que existirían antes de su lucha. Sino que la lucha de clases es la forma histórica de la contradicción (interna a un modo de producción) que divide a las clases en clases:

Que la burguesía, en su ideología, haga silencio acerca de las relaciones de producción y la lucha de clases, para exaltar la "expansión" y la "productividad" al mismo tiempo que el Hombre y la libertad, es su asunto, y ello está en orden, su orden, puesto que ese

silencio le sirve y le permite a la pareja economicismo/ humanismo, que expresa el punto de vista burgués, trabajar para disimular, asegurar y reproducir las relaciones de explotación. ¡Pero qué partidos obreros, antes de la Revolución, o después, hagan ellos también silencio (o semisilencio) acerca de las relaciones de producción y la lucha de clases y sus formas concretas para exaltar conjuntamente las fuerzas productivas y el Hombre, es una cosa completamente distinta!

Porque, si no se trata sólo de palabras o de algunos discursos, sino de una línea y de prácticas coherentes, se puede afirmar, como lo hizo Lenin de la II Internacional antes de la guerra de 1914, que el punto de vista burgués contamina, puede amenazar e incluso dominar al punto de vista proletario en el propio marxismo.

(PLC: 33)

De esta manera, para Althusser siguiendo a Marx y a Lenin, "la potencia revolucionaria de las masas sólo es potencia en función de la lucha de clases" (Ibíd.: 34). Pero esta "lucha de clases no se desenvuelve en el aire" sino que tiene una existencia material. Esta materialidad es, en última instancia, la unidad de las relaciones de producción de un modo de producción dado, en una formación social histórica concreta, puesto que es en las condiciones materiales de explotación que está fundado el 
antagonismo de clases. Con lo que Althusser busca enfatizar la tesis del enraizamiento de todas las formas de la lucha de clases "en la lucha de clase económica" (EA: 36).

Afirmar la primacía de la lucha de clases, implica reconocer que no son los sujetos los que hacen la historia, sino de que la historia es un proceso sin sujeto. En otras palabras: la negación de que la esencia humana es el sujeto de la historia implica, por un lado, reconocer que el papel que los individuos representan en la historia como individuos es el de personificaciones/ posiciones dentro del proceso, no el de sujetos (Callinicos, 1975: 66), y por otro, que la historia es el resultado de la lucha de clases, las cuales son determinadas históricamente (ibíd.: 67).

Este énfasis en la primacía de la lucha de clases, y del descentramiento del sujeto, son transversales y centrales en la intervención materialista de Althusser; que incluye a las formulaciones del "último Althusser". Con lo cual, desde nuestra perspectiva, no hay cortes al interior del pensamiento althusseriano, aunque sí, fisuras, lagunas y silencios, que proponemos leer sintomáticamente. En este sentido, mostraremos que, la Filosofía de "el último Althusser" refuerza su posición materialista, que implica un combate y una demarcación con el idealismo. A continuación, proponemos examinar con más detalle la propuesta althusseriana de una "nueva práctica de la filosofía" comandada por la lucha de clases.

\section{La "nueva" práctica de la filosofía}

Toda filosofía es polémica: se posiciona en contra (o a favor) de la filosofia dominante. Así, por ejemplo, Descartes contra los escolásticos, Spinoza contra Descartes, Hegel contra Kant, Derrida a favor y en contra de Heidegger, yo a favor de Maquiavelo (pero contra todos).

(Althusser, El materialismo aleatorio)

La propuesta althusseriana de una "nueva práctica de la filosofía" se inscribe en su intervención materialista que se demarca de la filosofía tradicional, de tipo idealista con pretensiones de darse a un objeto como fundamento. En contraste con ello, la práctica de la filosofía propuesta por Althusser "no tiene objeto", no en el sentido de que carezca de contenido, sino que se trata de una ausencia de garantías bajo las que se desarrolla la filosofía tradicional (Origen Fin, Sentido, Sujeto). Por ello es que: 
el carácter forzado, semblanteado de la coherencia filosófica tradicional (señalando sus huecos, sus vacíos, es decir, los lugares donde un discurso busca domeñar las fuerzas en tensión que lo componen) como el intento de controlar un antagonismo irreconciliable entre cuyas líneas puede leerse su relación con la política, con la lucha de clases.

En otros términos, la filosofía tiene también que ver con la política, y la distinción entre ciencia e ideología no se traza de una vez y para siempre, sino coyunturalmente (la filosofía es esencialmente intervención y no saber), de donde se sigue que a la misma le corresponde un carácter político específico e irreductible.

(Karczmarczyk, 2016b: 277)

A partir de la autocrítica de Althusser donde comienza a tener un estatuto central la dimensión disruptiva de la política, la nueva práctica de la filosofía se interroga por su intervención en su coyuntura histórica, es decir, en una formación social concreta. Sin embargo, "está forzada a reconocer que su terreno de intervención es un territorio ya ocupado por discursos que remiten a un objeto, como a una garantía" (Ídem). La formulación del terreno de intervención como un campo de disputas se encuentra en analogía con el campo del arte en "El 'Piccolo', Bertolazzi y Brecht” ...

Althusser argumenta que Brecht al plantear -desde el terreno del teatro- que la teoría y la práctica teatral está atravesada por la dimensión política; es un antecedente de lo que ocurre con nueva propuesta de una práctica filosófica. ¿Pero cómo lo hace? Brecht propone el término de verfremdung para referir a la distancia necesaria para la autorreflexión de la conciencia melodramática, para la crítica de la ideología; por la cual "las obras teatrales dejan de referir a sí mismas" para pasar a referir al exterior. Por ello es que, para Althusser en "El Piccolo, Bertolazzi y Brecht...": "jamás se ha representado con tanta fuerza, en la estructura del espacio, en la distribución de los lugares y de los hombres, en la duración de los gestos elementales, la relación profunda de los hombres con el tiempo en que viven" (RTM: 112).

Ahora bien, que la nueva práctica de la filosofía rechace las pretensiones de coherencia de la filosofía tradicional que busca "acallar" el conflicto, no es una mera denuncia; sino que implica una intervención política bajo la que subyace la idea de que "la filosofía representa la lucha de clases en la teoría” (FAR: 20. ¿Por qué entonces la filosofía libra una lucha por el sentido de las palabras? La respuesta a esta cuestión se encuentra en la siguiente cita: 
...las realidades de la lucha de clases están "representadas" por medio de "ideas" que son "representadas" por medio de palabras. En los razonamientos científicos

y filosóficos, las palabras (conceptos, categorías) son "instrumentos" del conocimiento. Pero en la lucha política, ideológica y filosófica, las palabras también son armas, explosivos,

calmantes y venenos. Toda la lucha de clases puede a veces resumirse en la lucha por una palabra o contra una palabra. Algunas palabras luchan entre ellas como enemigos. Otras palabras dan lugar a un equívoco: la apuesta por una batalla decisiva pero indecisa (...). Este combate filosófico por las palabras es una parte del combate político. La filosofía marxista-

leninista no puede realizar su trabajo teórico, abstracto, riguroso, sistemático, sino con la condición de luchar también por palabras muy sabias" (concepto, teoría, dialéctica, alienación, etc.) y sobre palabras muy simples (hombre, masas, pueblo, lucha de clases...

(FAR: 21. Cursivas del original)

En este sentido, cabe señalar que la preocupación althusseriana por el estatuto político de la filosofía no es una deriva abstracta, sino que se inscribe en el centro de una preocupación por la política, que como ya hemos dicho, comienza a tener mayor fuerza a partir de su concepción rectificada de la teoría.

En sintonía con ello, en el texto póstumo escrito en 1976 y publicado en 2015: Ser Marxista en Filosofía Althusser destaca el vínculo orgánico entre la filosofía marxista y la política, ya que la primera representa la lucha de clases en la teoría, es decir, la política" (SMF: 14). Que la filosofía represente la lucha de clases en la teoría implica reconocer la primacía de la práctica por sobre la teoría. Lo que se vincula con aquello que Althusser afirma en otro texto póstumo, de 1975: Iniciación a la filosofía para no filósofos (IF, 2015): “indudablemente el mandato de una nueva práctica de la filosofía, indispensable en la lucha y para la lucha del proletariado, proviene de la lucha de clases proletaria" (Ibíd.: 216- 217). En este marco, el proletariado no es una clase explotadora, sino únicamente una clase explotada. Las relaciones de producción a las que está sometido le son impuestas desde afuera, por la burguesía capitalista "no constituyen su fuerza, sino antes bien, su debilidad,

Como solo tiene sus brazos para vivir y solo tienen sus ideas y sus fuerzas para combatir, necesita una ideología propia para unir sus fuerzas y oponerlas a las que reúne la ideología burguesa. Para unificar los elementos ideológicos de que puede disponer y que son en parte herencia de la larga historia de la lucha de los oprimidos, el proletariado tiene además necesidad de una filosofía propia que ajuste el conjunto de sus armas ideológicas para el 
combate de clases.

(IF: 217)

De lo anterior se sigue, que la filosofía no es omnipotente de decidir su propio destino y la orientación de su combate, ya que "en la teoría, la filosofía no es más que la delegación de la lucha de clases económica, política e ideológica. Es en última instancia, lucha de clases en la teoría" (Ibíd.: 226). Esto quiere decir que, la filosofía lo que hace es tomar su lugar en la continuidad de una lucha secular.

En esa dirección, si la filosofía quiere representar la concepción del mundo de una clase revolucionaria en la filosofía, pero de una clase que, "al no explotar a ninguna otra clase, aspira a la supresión de todas las clases, debe presentar lucha en el campo de batalla filosófico existente y aceptar las reglas del combate, pero en ese mismo campo y sin equivocarse de adversario" (Ídem. Cursiva del original).

¿Qué significa esto? La filosofía en cuestión ocupa posiciones definidas contra un adversario definido, puesto que "cada filosofía aparece, así como una suerte de ejército teórico, desplegado en el campo de batalla, precedido y constituido por sus tesis que son sus destacamentos ofensivos destinados a ocupar el terreno en pugna, que el adversario ha ocupado ya o pretende ocupar" (Ibíd.: 194). Esto permite comprender que para Althusser la filosofía no tenga objeto, ya que no tiene finalidad de producir conocimiento, sino que su fin es una guerra estratégica y táctica contra las fuerzas teóricas del adversario que, como toda guerra, pone en juego muchas cuestiones ${ }^{42}$. Tenemos que representarnos, sostiene Althusser, la filosofía como el conjunto de las diferentes filosofías en cada época, como un campo de batalla teórico Kampfplatz ${ }^{43}$.

En el marco de una intervención materialista como la de Althusser, el campo de batalla es "la demarcación entre materialismo e idealismo" (SMF: 16), aunque cambiaran sus nombres. En esta dirección, si la filosofía no tiene historia, podría decirse que su historia podría ser en última instancia, esta demarcación. Puesto que para Althusser: "toda filosofía es solamente la realización más o menos lograda de una de las dos tendencias antagónicas: la tendencia idealista y la tendencia materialista. Y en cada

\footnotetext{
${ }^{42}$ En el Curso de filosofía para científicos, señala que la filosofía no tiene objeto, y que sólo puede realizar transformaciones dentro de sí misma.

${ }^{43}$ Althusser recoge esta expresión de la filosofía kantiana, una provocación que se articula con otra que señala Tosel (2016) y que consiste en mantenerse en el léxico conceptual del contrincante (en este caso, un representante de la filosofía idealista, como tantos otros). Esta estrategia filosófica también es heredada de Spinoza, según Tosel, quien comienza por Dios, para hacer justamente una de las críticas más potentes a la religión.
} 
filosofía se realiza, no la tendencia, sino la contradicción entre las dos tendencias" (IF: 195). Esta prolongación ininterrumpida del conflicto se produce porque, de acuerdo con la perspectiva althusseriana, hay una necesidad de toda filosofía, incluyendo a la filosofía marxista (o más bien, a la "posición marxista en filosofía" o la "nueva práctica, marxista, de la filosofía") de pasar por el rodeo de otras filosofías para definirse y captarse a sí misma en su diferencia: en su división.

Entonces bien, el campo filosófico es comprendido, bajo esta lupa, como un campo de luchas de tendencias, Kampfplatz, en el que el materialismo, o la posición materialista en filosofía, es una toma de posición que se demarca de las filosofías de la historia, teleológicas, idealistas. Esta práctica política y filosófica de Marx y sus sucesores, si se toma en cuenta, dice Althusser, debería dar lugar al comienzo de una salida de la profunda crisis en la que se sumergió la filosofía marxista desde la II Internacional y desde Stalin. Por tanto, practicar la manera filosófico- política de combatir dentro de la filosofía, es en última instancia, una forma teórica de la política en la que se lucha por el sentido de las palabras. (Ibíd.: 194).

Pero, ¿cuál es en este marco, el sentido práctico de las proposiciones filosóficas? Althusser afirma que una tesis filosófica se compone de términos abstractos, las categorías, que se distinguen de los conceptos científicos. Una categoría no tiene un objeto real, sino que es un objeto puramente interno de la filosofía (IF: 194), que llega a ser un medio de ocupar un terreno imponiéndose a un adversario filosófico.

En su Defensa de Tesis..., Althusser señala que las categorías cumplen una función teórica: "se engastan con el resto de categorías, que no puede suprimirse del conjunto sin alterar el funcionamiento del todo" (SM: 241). De allí la importancia de practicar una filosofía no filosófica, una antifilosofia, que permita pasar a la ofensiva en un campo de batalla, siempre ya minado por otras posiciones y "deconstruir la gran tradición de la filosofía idealista" (SMF: 15). De lo que se trata entonces es de practicar una filosofía que:

... hace tambalear a la filosofía tradicional y permite comenzar a ver claro en el interior de la filosofía, por basarse, además, en la posibilidad de transformar el mundo. La irrupción de la práctica es la denuncia de la filosofía producida como tal Filosofía. Es decir, contra la pretensión de la Filosofía (tradicional) de abarcar el conjunto de las prácticas sociales (y las ideas), de ver el "todo" como decía Platón, para establecer su dominio sobre estas mismas prácticas; es contra la suposición de la Filosofía de no tener "un espacio exterior" por lo que el 
marxismo afirma, sin duda, que la filosofía tiene un "exterior", es decir, que la filosofía no existe más que por ese "exterior" y para él. Este exterior (que la filosofía quiere hacerse la ilusión de someter a la Verdad) es la práctica, son las prácticas sociales (...) La práctica es aquella otra cosa, a partir de la cual, no sólo se puede hacer tambalear a la filosofía sino, más aún, aquello gracias a lo cual se puede comenzar a ver claro en el interior de la filosofía...

(F y M: 55- 56)

Pero, no basta con deletrear las palabras de una teoría, hay que ver cómo actúa, puesto que es un dispositivo de tesis, lo que rechaza y lo que autoriza. Recordemos en este sentido que, la ideología dominante ("la ideología de la clase dominante" según Marx) cumple la función de permitir que la clase social que ha tomado el poder del Estado llegue a ser dirigente. Sin embargo, señala Althusser: "también sabemos que esta ideología dominante no tiene únicamente la función de subyugar a los explotados y de unificar la sociedad bajo la dominación de la clase que está en el poder. Su primera función es unir a esta misma clase" (IF: 199), transformar los aparatos del Estado que heredó, unificar el Estado y reforzar su unidad. Sin embargo, Althusser señala que la clase dominante choca contra la diversidad material de las prácticas y de las ideologías “que tales prácticas inspiran y que a su vez las gobiernan” (Ibíd.: 200).

Entonces bien, existe en este marco un fuerte vínculo entre la filosofía tradicional y la unificación ideológica, ya que "la unificación de los elementos ideológicos existentes en una ideología dominante es, pues, una tarea de la lucha de clases de la clase dominante y se realiza a través de formas derivadas de la lucha de clase" (SM: 203). Por ello, el estatuto central de la filosofía "para intervenir en este combate teórico es irreemplazable" (Ídem) que ninguna otra práctica puede cumplir. Puesto que, "Ser marxista en filosofía es entrar en el debate filosófico para representar la ciencia de la filosofía a la que se juzga, en última instancia, como una forma teórica de la política, y, por ende, de la ideología" (SMF: 15).

Un efecto de este posicionamiento materialista es la afirmación de la primacía de la práctica sobre la teoría. "Y la práctica es en todo, contraria y extraña al logos. No es la verdad y no se reduce ni se realiza en el ver (la intuición) ni en el decir (logos)" (F y M: 55). La práctica es desde este marco materialista, un proceso de transformación sometido a sus propias condiciones de existencia, y no produce la "Verdad", sino conocimientos en el interior de una problemática de sus propias condiciones de existencia. 
Pero, además, esta práctica no es llevada a cabo por "sujetos", por un "sujeto" de origen trascendental $\mathrm{u}$ ontológico, sino agentes, que no tienen una finalidad como verdad anticipada de su proyecto, sino que se trata de un proceso sin sujeto (ahistórico). Así, contra toda ideología burguesa "trufada de humanismo", Marx -en la lectura de Althusser- muestra que lo que determina en última instancia una formación social y lo que posibilita el conocimiento de la misma, "no es el fantasma de una esencia o de una naturaleza humanas" no es el hombre, no son siquiera "los hombres"; sino una relación, la relación de producción que constituye la base, la infraestructura.

Contra todo idealismo humanista, Marx mostraría que la relación de producción es una relación doble: entre grupos de hombres; y entre grupos de hombres y cosas: los medios de producción: "La relación de producción es, dice Marx, una relación de distribución, distribuye a los hombres en clases al mismo tiempo y según atribuye los medios de producción a una clase. Las clases nacen del antagonismo de esta distribución que es al mismo tiempo una atribución" (SM: 243).

Con lo cual, la lucha de clases, es el elemento ontológico fundamental de la posición materialista en filosofía. Destacar la transversalidad de la lucha de clases, como motor de la reflexión filosófica althusseriana, implica recusar de aquellas lecturas, como la de Antonio Negri, que "ven" un giro o Kehre al interior de su filosofía, atendiendo al desarrollo del "último" Althusser, el del materialismo aleatorio en comparación con los "otros Althusser".

\section{La filosofía en el "último" Althusser: el materialismo aleatorio}

¿Qué eres, figura del dado que hago girar en tu encuentro con mi fortuna? (Lacan, seminario sobre "La carta robada")

La filosofía de Althusser realiza un camino sinuoso. Desde la década de los ' 70 hasta la de los ' 80 del siglo pasado, se ve afectada por la crisis del marxismo (crisis de los marxismos reales en Rusia y China que ponen en jaque las ideas centrales del marxismo teórico), y que conduce a una especie de borramiento de la filosofía althusseriana; que se profundiza con el femicidio de su mujer Hélène Rytmann en $1980^{44}$.

\footnotetext{
${ }^{44}$ El término femicidio se acuña en 1992 (paradójicamente, puesto que es el año en que se publica la autobiografia de Althusser donde narra el trastorno psíquico en el que se encontraba cuando ocurrieron
} 
Sin embargo, después de la muerte física de Althusser en 1990, su filosofía empieza a renacer, en parte debido a la publicación en 1992 de su autobiografía escrita en 1985: El porvenir es largo - de hecho, el primer texto del programa de publicación de las obras póstumas- que forma parte del proyecto de Althusser de retomar la palabra, de intervenir nuevamente como "sujeto- político- filosófico", luego de que fuese silenciado, y de que se sentenciara que el proceso de declaración por parte de Althusser no tendría lugar.

Por otra parte, el renacimiento de la obra althusseriana - que se manifiesta en el interés que han ido cobrando sus obras a nivel internacional expresado en diversos congresos, y reuniones científicas en torno al pensamiento del autor- se vincula fuertemente con la publicación que el IMEC (Institut Mémoire d' Édition Contemporaine) realiza de textos inéditos de los ' 60 y '70 de Althusser (más de 50.000 páginas póstumas). Estos textos reponen, de alguna manera, el silencio en la que estaban sumergidas sus obras e impactan en la comprensión integral de la obra althusseriana. Pero, la "comprensión integral" del pensamiento de Althusser se ve obstaculizada por una cuestión: la exaltación de los textos tardíos (que para Goshgarian representan sólo una parte de los textos póstumos ${ }^{45}$ ), comprendidos como "completamente distintos" en relación a sus textos anteriores, como si hubiese un corte al interior de la obra althusseriana.

En este sentido, ante la pregunta de Félix Boggio Éwanjé-Épée: - “¿ha sido distorsionada la obra póstuma por una atención desmesurada prestada a la producción del 'último Althusser' o por una recepción que ha exagerado la discontinuidad entre el 'ultimo' Althusser' y los otros?' (Goshgarian, 2016: 9)- Goshgarian responde, a modo de conclusión provisoria, que lo que la recepción del pensamiento althusseriano parece saltearse es que el materialismo aleatorio "es pensado a partir de un concepto fundador de toda la obra althusseriana: la dictadura del proletariado ${ }^{46}$ (Ibíd.: 11). Y a modo

\footnotetext{
"los hechos") por la necesidad de utilizar una categoría interpretativa que tuviera un significado, una trascendencia inédita de tipo social, epistemológico, cultural, político y jurídico para entender "el asesinato de mujeres por hombres por ser mujeres" (Radford y Russell, 2006). Haciendo una lectura atenta de El porvenir es largo (que, sin lugar a dudas, da lugar a otra investigación) es que argumento mi decisión de emplear este concepto en este caso.

${ }^{45}$ Para Goshgarian, "la producción completa del 'ultimo Althusser' termina siendo una gota en el mar de las publicaciones póstumas del primer periodo" 45 (Goshgarian, 2016: 6).

${ }^{46}$ Goshgarian problematiza aún más la cuestión y señala que si la dictadura del proletariado, "el concepto clave de la doctrina marxista" es la piedra angular del marxismo althusseriano desde los años 1950, el mismo no aparece sino raramente con su propio nombre en los textos anteriores a 1976.
} 
general, implica la lucha de clases.

Este concepto, dice Goshgarian, sirve de puente en "el último Althusser", entre el pensamiento del surgimiento del mundo a partir del vacío, y la filosofía sui generis (Ídem). Se trata de un concepto que refuerza su intervención materialista, puesto que el factum de la lucha de clases sería impensable sin la existencia, de hecho, de clases antagónicas. Como señalara el propio Althusser con las siguientes palabras:

...ese punto de vista de la lucha de clases en los Aparatos Ideológicos del Estado permanece siendo todavía abstracto. En efecto, la lucha de clases en los Aparatos Ideológicos del Estado es por cierto un aspecto de la lucha de clases. Pero la lucha de clases en los Aparatos

Ideológicos del Estado es sólo un aspecto de una lucha de clases que desborda los Aparatos Ideológicos del Estado. La ideología que una clase en el poder torna dominante en sus Aparatos Ideológicos del Estado se "realiza” efectivamente en esos Aparatos Ideológicos del Estado, pero

los desborda porque proviene de otra parte. Del mismo modo, la ideología que una clase dominada logra defender en y contra tales Aparatos Ideológicos del Estado los desborda, porque proviene de otra parte... (Proviene) de sus condiciones de existencia, de sus prácticas, de sus experiencias de lucha, etc. (Althusser, Posiciones. Citado por De Ipola, 2007: 148)

Comprender la continuidad, aunque no monolítica sino mediante rectificaciones, rodeos, recomienzos y retornos en el sentido de remonter (volver a una cuestión, pero desde un punto de vista ascendente) es la forma en que se debe comprender la intervención materialista de Althusser de manera integral. Una posición que, desde nuestra perspectiva, no implica cortes ni virajes con sus posicionamientos anteriores, sino que profundiza y refuerza tesis centrales de su materialismo que se encuentra a lo largo de toda su obra como lo son: a) su propuesta del antihumanismo teórico de Marx y del proceso sin sujeto; b) rechazo a la postulación de un sujeto constituyente y el rechazo a las categorías idealistas con la que se articula: Origen y Fin, Sentido, y Sustancia; c) consecuentemente, el rechazo al tratamiento idealista de la ideología; d) la concepción del todo complejo sobredeterminado: y f) la primacía de la práctica por sobre la teoría, que se manifiesta también en la propuesta de una nueva práctica de la filosofía, en la que existe una primacía del proceso por sobre el "sujeto".

Estas consideraciones son fundamentales para destacar el posicionamiento materialista transversal en la obra de Althusser. Es bajo esa premisa que, en este apartado proponemos explorar uno de los textos tardíos: La corriente subterránea del 
materialismo del encuentro de 1982-texto que se presenta como fundador del Althusser tardío- para señalar una continuidad de las tesis centrales de su intervención materialista.

La Corriente subterránea...-texto extraído de un manuscrito de 1982/1983 por Matheron y publicado en el primer tomo de Écrits philosophiques et politiquescomienza con una referencia a la lluvia de Lucrecio y los átomos de Epicuro que caen en paralelo en el vacío: Siguen y seguirán cayendo hasta el fin de los tiempos. Lo que implica, por un lado, que antes del mundo no había nada; y al mismo tiempo, que todos los elementos del mundo existían antes de toda eternidad, antes de que ningún mundo existiera. En ese "antes" sobreviene el clinamen, la operación originaria (De Ipola, 2007: 194). El clinamen, explica Althusser, es una "desviación infinitesimal” que tiene lugar "no se sabe dónde, ni cuándo, ni cómo"; y que hace que un átomo se desvíe de su caída en el vacío y -rompiendo de manera casi nula el paralelismo en un puntoprovoque un "encuentro" con el átomo que está al lado y de encuentro en encuentro una carambola y de esa carambola el nacimiento de un mundo. Es decir, del agregado de átomos que provocan en cadena la primera desviación y el primer encuentro.

Con esta metáfora de la lluvia, Althusser busca establecer una demarcación con las filosofías idealistas que proponen un Origen; frente a lo cual enfatiza que antes de la formación del mundo no existía ningún Sujeto, ningún Sentido, ni Causa, ni Fin, ni Razón ni sinrazón. Además, este materialismo del encuentro, comporta un carácter subversivo puesto que, si los átomos de Epicuro se encuentran es "para dar a conocer en la desviación que produce el clinamen, la existencia de la libertad humana en el mundo de la necesidad" (ME: 32).

Este carácter subversivo del materialismo aleatorio es lo que explica en gran medida, el interés por parte de los defensores de la tradición filosófica por "esconderlo" y proponer en cambio, un "idealismo de la libertad". Puesto que, como señala Althusser en la siguiente cita, lo que denuncia esta posición materialista, es el enmascaramiento de las condiciones reales de existencia -que son también explicadas como producto de un "encuentro" que ha "tomado consistencia" -bajo la idea de libertad:

En innumerables pasajes, y no precisamente por azar, Marx nos explica que el modo de producción capitalista ha nacido del "encuentro" entre el "hombre de los escudos" y el proletario desprovisto de todo excepto de su fuerza de trabajo. "Sucede" que este encuentro ha tenido lugar, y ha "tomado consistencia", lo que quiere decir que no se ha deshecho 
inmediatamente después de hacerse, sino que ha perdurado y se ha convertido en un hecho consumado, el hecho consumado de este encuentro, provocando relaciones estables y una necesidad cuyo estudio proporciona "leyes", evidentemente tendenciales...

En efecto, Althusser enfatiza en La corriente subterránea ... la existencia de una tradición materialista casi completamente desconocida en la historia de la filosofía donde se encuentra Lucrecio, Epicuro, Spinoza, Maquiavelo, Hobbes, Rousseau, Marx, Heidegger y Derrida ${ }^{47}$ - y que por ello caracterizó como corriente subterránea (courant souterrain); utilizando una representación topográfica que sugiere un movimiento por debajo de la filosofía, un movimiento que también podría ser en contra (á-contrecourant) pero fuera del campo de visión, es decir una corriente que no puede ser vista. Montag problematiza el hecho de que se haya comprendido "subterráneo" como "subyacente", en el sentido de un develamiento que afirma los textos clásicos de Althusser. Frente a lo cual propone una lectura radicalmente distinta, "no como la respuesta a las preguntas que los textos del Althusser clásico exhibirán en estado práctico (...) sino de valerse de las tensiones e inconsecuencias de un texto para traer a la luz algo nuevo" (Karczmarczyk, 2016b: 274) ${ }^{48}$.Además, Montag señala que esta representación metafórica puede ser engañosa para describir la corriente subterránea ya que los filósofos a los que Althusser se refiere como perteneciendo a esta corriente (con la excepción parcial de Epicuro y Lucrecio cuyas obras pertenecieron bajo custodia por siglos) estaban "escondidos a plena vista". Es decir, parafraseando "La carta robada", como si no se los estuviera leyendo al ser leídos, como si no se los estuviera viendo al mirarlos (cfr. Lacan, 2012: 23-69; Masotta, 2015: 42-46).

\footnotetext{
${ }^{47}$ Para André Tosel se trata de "una genealogía sorprendente. La investigación althusseriana se presenta como la genealogía de una corriente subterránea, o, mejor dicho, como la revelación de momentos discontinuos de ese río cárstico, a través de la exposición de las tesis filosóficas consideradas más pertinentes" (Tosel, 2016: 2).

${ }^{48}$ De acuerdo con la hipótesis de Karczmarczyk, la lectura típica de los textos tardíos se ve alterada por la novedosa lectura de "La corriente subterránea del materialismo del encuentro" realizada recientemente por Montag. La misma consiste en leer el célebre texto tardío sobre "La corriente..." a partir de un texto de una resonancia casi nula, el texto sobre "La internacional de los buenos sentimientos". Montag pretende que la mejor posición de lectura de "La corriente..." no es tanto la que sugiere su propia caracterización como "legado" o "testamento", esto es, como un texto a fin de cuentas afirmativo, sino como un texto interrogativo. "nos propone abordar a "La corriente..." como un texto que formula preguntas que no acierta a responder, pero insistiendo en que, jvaya sorpresa!, estas respuestas pueden encontrarse un texto anterior, en verdad el primero escrito por Althusser del que tengamos noticias" (Karczmarczyk, 2016b: 274).
} 
Cabe señalar (brevemente, porque lo abordaremos en la II parte) que en "el seminario sobre "La carta robada", Lacan realiza una rotunda crítica a la teoría tradicional del conocimiento, de la que se demarca para plantear que nos encontramos inmersos en un orden simbólico del que no somos los creadores, sino que cumplimos una función- sujeto. En este marco, es la estructura (la carta) la que decide nuestro destino y nuestra suerte, aunque imaginariamente creamos lo contrario; por efecto de la ideología y el automatismo de la repetición ${ }^{49}$ ).Sin embargo, es la fícción de la carta robada, según Lacan, la que produce los efectos dentro de la estructura: "sobre los actores del cuento, incluido el narrador; tanto como fuera: sobre nosotros, lectores, e igualmente sobre su autor, sin que nunca nadie haya tenido que preocuparse de lo que quería decir. Lo cual de todo lo que se escribe es la suerte ordinaria” (Ibíd.: 65).

Lo cual tiene total sentido, puesto que en el cuento de $\mathrm{Poe}^{50}$, los personajes desarrollan su papel creyendo que son autónomos, pero en realidad están determinados por el lugar que ocupan en la estructura social. El sentido lo impone la carta cuyo contenido es: “...un designio tan funesto, si no es digno de Atreo es digno de Tieste”. De allí la pertinencia de la hipótesis de Oscar Masotta: "entre la superficie y la profundidad se encubre la materialidad específica de la lectura y la escritura, incluso la del sentido y la del sinsentido" (Masotta, 2015: 12).

Entonces bien, el materialismo aleatorio, "el materialismo de la lluvia, la desviación, el encuentro y la toma de consistencia" ${ }^{51}$ rechaza toda la cuestión del origen así como otras grandes cuestiones de la filosofía tradicional, tales como las del Sentido, el Sujeto, el Fin teleológico y la Razón. De hecho, según Althusser, la "profunda tradición materialista, desde Epicuro a Marx, ha sido sepultada por renunciar a pensar el origen como razón o fin para pensarlo como nada" (ME: 32. La cursiva es nuestra). La aleatoriedad "no supone nada preestablecido" puesto que es "en el vacío político donde puede realizarse el encuentro" (Ibíd.: 33), tal como da cuenta la siguiente cita:

\footnotetext{
${ }^{49}$ Esta repetición es repetición simbólica, se muestra en ella que el orden del símbolo no puede ya concebirse como constituido por el hombre sino como constituyéndolo" (EE: 55).

${ }^{50}$ El contenido, o uno de los contenidos de La lettre volée ("la carta robada") de Poe, traducida así por Baudelaire: "Destino tan funesto, si no es digno de Atreo es digno de Tieste" lo que se revela -para decirlo panorámicamente- es que hay algo en el pasado que sigue ejerciendo su acción en el presente, se trata, de una relación inconsciente en el nivel de lo simbólico.

${ }^{51}$ Nota al pie del autor: "Traducimos prendre por "tomar consistencia" (y, por lo tanto, prise por "toma de consistencia"). La idea que subyace es la de elementos que, "al encontrarse", "se toman", "se prenden", "se enganchan" y, con ello, dan lugar a algún tipo de consistencia física que antes no existía. En los lugares en los que no se utiliza como término técnico o en los que esta traducción generaría problemas de comprensión del texto, lo traducimos simplemente por "tomar" (ME: 32. El énfasis es mío).
} 
La burguesía, en efecto, no es más que el elemento predestinado a unir todos los otros elementos del modo de producción, que realizará con ellos otra combinación, la del modo de producción capitalista. Esta es la dimensión del todo y de la teleología, que asigna a cada elemento su papel y su sitio en el todo, y los reproduce en su existencia y en su papel. Estamos en las antípodas de la concepción del "encuentro entre la burguesía" (elemento tan "flotante" como los otros) y otros elementos flotantes para constituir un modo de producción original: el capitalismo. No hay entonces encuentro, pues la unidad precede a los elementos, pues no hay ese vacío necesario para todo encuentro aleatorio. Cuando se trata todavía de pensar el hecho a consumar, Marx se coloca deliberadamente en el hecho consumado y nos invita a seguirle por las leyes de su necesidad.

Pero este vacío político es antes que nada un vacío filosófico, donde no existe ninguna causa que preceda a sus efectos, ya que "en vez de partir de los famosos problemas filosóficos y metafísicos, comienza por evacuarlos para sólo partir de la nada y de esa variación- infinitesimal y aleatoria que es la caída" (Navarro, 2006: 6). Como señala el propio Althusser, esta filosofía de la nada, es:

En todo y por todo una filosofía del vacio: no solamente la filosofía que dice que el vacío preexiste a los átomos que caen en él, sino también una filosofía que hace el vacio filosófico para darse la existencia: una filosofía que en lugar de partir de los famosos “problemas filosóficos” (“¿por qué hay algo en vez de nada?”) comienza por evacuar todo problema filosófico, esto es, por renunciar a darse un "objeto", cualquiera que sea ("la filosofía no tiene objeto"), para partir sólo de nada (rien), y de esa variación infinitesimal y aleatoria de la nada que es la desviación de la caída...

Que Althusser postule una filosofía del vacío como condición de posibilidad de la libertad y del movimiento ante la ausencia de obstáculos, es coherente con el propósito de "librar de su represión a este materialismo del encuentro" y de descubrir las implicancias que tiene para la filosofía y para el materialismo, "reconociendo sus efectos escondidos ahí donde actúan sordamente" (Ídem). Aludiendo de esta manera al discurso del inconsciente, un discurso que se puede ver a partir de una lectura doble, de acuerdo con el protocolo de lectura materialista propuesto por el propio Althusser. Una 
lectura que trata de "alumbrar", no en el sentido de iluminar un significado ya presente, sino de valerse de las tensiones e inconsecuencias de un texto para traer a la luz algo nuevo, para conferir a las tensiones e inconsecuencias, en las que un texto manifiesta su revés, una nueva forma de existencia, propiamente conceptual, en la que podrán alojarse nuevas tensiones, más productivas" (Karczmarczyk, 2016b: 274).

Entonces bien, este materialismo aleatorio rechaza las nociones propias de la teoría tradicional del conocimiento como las de Sentido, Sujeto, Sustancia, Origen- Fin. Tosel señala en esta dirección que, la deconstrucción operada por el materialismo aleatorio se aparta "del modo filosófico de pensar para liberar los elementos teóricos positivos que puede integrar y convertirlos en átomos para otros encuentros bajo combinaciones" (Tosel, 2016: 9). Respecto al concepto de "Sentido", Tosel señala que se trata de la idea onto-teológica y metafísica de que existe una significación, un logos, una razón que precede al mundo o que allí se revela. Frente al cual "el vacío del Sentido libera del Orden y abre el des-orden del acontecimiento" (Ibíd.: 10). En cuanto a la "Sustancia" se trata de un sustrato unitario que garantiza la homogeneidad de todos los elementos y accidentes que surgen a partir de él. Impide pensar en las cosas como complejas materialidades, múltiples y diversas.

El "Sujeto" es para Tosel la categoría central del idealismo y sobre todo del idealismo de la libertad, de la cual no se liberó ni Marx ni el marxismo, por ejemplo, Gramsci. "Es la idea de una individualidad estable, presente a sí misma, que busca realizarse en la continuidad de sus proyectos, en nombre de su libertad y sus derechos propios, ignorando los mecanismos ideológicos que lo interpelan como tal y lo colocan en escena. No ve su propia espalda" (Ídem.). En este sentido, y reforzando lo que nos interesa abordar en este trabajo, el materialismo del encuentro no es el de un sujeto (ya fuese Dios o el proletariado), sino el de un proceso sin sujeto pero que impone a los sujetos (individuos u otros) a los que domina el orden de su desarrollo sin fin asignable.

Por último, en cuanto a Origen y Fin, se trata de las categorías que terminan por estructurar el idealismo de la libertad, según Tosel: “el origen no es sino la anticipación del Fin en el interior de un Orden primordial (...) El origen, restablecido y enriquecido en su desarrollo, es el Fin" (Ibíd.: 11). Se configura así la matriz teleológica que encarna necesariamente el par Origen- Fin. La deconstrucción de este binomio es central, como prueba Althusser para dar cuenta que "la práctica es un proceso de transformación sometido a sus propias condiciones de existencia", que, además, produce no la Verdad sino 'verdades' de los resultados o conocimientos en el interior del campo de sus 
propias condiciones de existencia.

Recordemos que a partir de la rectificación althusseriana, se trata de prácticas desarrolladas por agentes, no por un sujeto como origen trascendental u ontológico de su proyecto "y no tiene tampoco una finalidad como verdad de su proceso. Se trata de un proceso sin sujeto(ahistórico)” (F y M: 55. El resaltado es mío). Las prácticas no están predeterminadas, por tanto, tampoco existe un 'modelo' o una práctica en general, sino prácticas distintas, cada una con una estructura propia, la de una producción; y con sus propios criterios de validación ${ }^{52}$. El desarrollo "no es el de un sujeto sino el de un proceso sin sujeto ni fin asignable. Se trata de una filosofía que tiene como ausente al Sujeto y que comienza por evacuar todo problema filosófico, esto es, por renunciar a darse un objeto, cualquiera que sea ("la filosofía no tiene objeto") para partir sólo de la nada (rien) y de esa variación infinitesimal y aleatoria de la nada que es la desviación de la caída. Desde nuestra lectura, existe un fuerte vínculo entre el materialismo aleatorio y un texto inédito que Althusser escribe en 1966 "Sobre la génesis" que se publica en 2013:

...no es el modo de producción feudal el que, por sí mismo y por una finalidad

providencial, engendra al mismo tiempo los tres elementos necesarios para que "prenda" la nueva estructura. Cada uno de esos elementos tiene su propia "historia" o su propia genealogía (por retomar un concepto de Nietzsche que Balibar ha utilizado felizmente para este propósito):

las tres genealogías son relativamente independientes. Vemos incluso a Marx mostrar que un mismo elemento (las fuerzas de trabajo "libres") puede ser producido como resultado por genealogías totalmente diferentes.

Así pues, las genealogías de los tres elementos son independientes las unas de las otras e independientes (en su coexistencia, en la coexistencia de sus resultados respectivos) de la estructura existente (el modo de producción feudal). Lo cual excluye toda posibilidad de resurgencia del mito de la génesis: el modo de producción feudal no es el "padre" del modo de producción capitalista en el sentido de que el segundo estuviera, hubiera estado contenido, "en germen" en el primero.

(SG: 1-2)

Mientras que, de manera análoga, en la carta 2 del 22 de agosto de 1966 a su

52 En este sentido, Ichida (2007) señala que el Althusser del 'materialismo aleatorio' no dejará de proponer el antihumanismo teórico como una de las bases para renovar el 'movimiento de liberación nacional' (p. 74). 
analista René Diatkine, Althusser reafirma la apuesta spinoziana de "leer la Escritura como se lee la naturaleza", esto es, atendiendo a sus lagunas y fisuras, recusando de toda ilusión de perfección en la que subyace en el fondo, una teoría teleológica y lineal del conocimiento, propia del empirismo y el idealismo:

Quien dice génesis dice: reconstitución del proceso mediante el cual un fenómeno A fue engendrado. Esta reconstitución es por sí misma un proceso de conocimiento: no tiene sentido (de conocimiento) más que si reproduce (reconstituye) el proceso real que engendró el fenómeno A. (.) Quien dice génesis dice desde el principio que el proceso de conocimiento es idéntico a todas sus partes, y en su orden de sucesión, al proceso de engendramiento real. Esto quiere decir que el proceso de conocimiento es por entero superponible de inmediato al proceso de engendramiento real. Esto quiere decir, empleando un lenguaje menos abstracto, que el que hace la génesis de un fenómeno A puede seguirle el rastro, en todas sus fases, desde su origen, al proceso de engendramiento real, sin ninguna interrupción, es decir, sin ninguna discontinuidad, laguna o ruptura (las palabras importan poco).

Este recubrimiento inmediato integral, sin ninguna interrupción, del proceso real por el proceso de conocimiento, implica esta idea, que parece evidente: que el sujeto del proceso real es un solo y mismo sujeto, identificable desde el origen del proceso hasta el final (...). (EP: 73. Cursivas del original. La negrita es nuestra)

De allí también el interés althusseriano en reivindicar la filosofía de Epicuro y de Maquiavelo por motorizar una filosofía del vacío para darse la propia existencia. Del primero porque "toda cuestión del origen queda rechazada, así como todas las grandes cuestiones de la filosofía: ¿por qué hay algo en vez de nada? ¿Cuál es el origen del mundo?" (ME: 34). Mientras que el segundo es reivindicado por Althusser porque formuló "toda una teoría filosófica del encuentro entre la fortuna y la virtú. El encuentro puede tener lugar o no. Puede fracasar. Puede ser breve o duradero: a él le es necesario un encuentro que dure. Por ello el Príncipe debe aprender a gobernar su fortuna gobernando a los hombres (...)" (Ibíd.: 37).

Este "materialismo del encuentro" de Maquiavelo ${ }^{53}$, nos dice Althusser, ha sido recogido por Spinoza; más precisamente "el encuentro no podría haber sucedido sin la

\footnotetext{
${ }^{53}$ En su lectura de El príncipe, Althusser insiste en el carácter fuertemente antihumanista de Maquiavelo quien, dado el lugar otorgado a la fortuna y a la contingencia, no postula anticipadamente un Sujeto de la práctica política. El lugar del Sujeto es un vacío desdoblado. El agente de la práctica política se constituye a partir de una política ideológica en curso que nada garantiza ni predetermina, y supone una alteridad entre el príncipe y el pueblo que impide hablar de una subjetivación absoluta, cerrada, o constituyente.
} 
presencia de Spinoza" ${ }^{54}$, quien comprendió mejor que nadie la fascinación de Maquiavelo por hacer política, y que se manifiesta en su Tratado político.

En efecto, en Maquiavelo, Althusser ve algo diferente a una ciencia de la política. Sino que lo que habría es un pensamiento político de la filosofía, capaz de intervenir en la coyuntura. Maquiavelo inauguraría así, un nuevo modo de practicar la filosofía que reside en dar cuenta del carácter excesivo de la política, de la herida que la política inscribe en la filosofía. Esto es, hay un desajuste irreductible entre la teoría y la política, entre lo real y su concepto. La primacía de la práctica, permiten disolver la pretensión de omnipotencia de la filosofía que tienen las perspectivas idealistas: "las filosofías materialistas afirman la primacía de la práctica, y la práctica es, ante todo, extraña al logos" (F y M: 55).

De acuerdo con la lectura althusseriana de Spinoza, "el objeto de la filosofía es el vacío" (Ibíd.: 41), una tesis "paradójica" 55 según el propio Althusser, de la que da cuenta el modo en que comienza la Ética: con Dios, que es "sólo naturaleza", o "no otra cosa que naturaleza", y "fuera de la naturaleza no hay nada" (Ídem) ${ }^{56}$.Recordemos que en el monismo de Spinoza todo es sustancia, y al serlo, no hay lugar para el no- ser, para la negación comprendida como no -ser. Por lo cual podría pensarse que no habría lugar para el vacío. Sin embargo, que la "filosofía no tenga objeto" es una manera de decir que el objeto por excelencia de la filosofía es la nada (le rien) o el vacío (le vide). Cabe atender aquí aquello que Althusser sostenía en el Curso de Filosofía para científicos de que la filosofía no tenía objeto, y que era el medio en que sus objetos propios existían: "la filosofía sólo interviene en la realidad produciendo resultados dentro de sí misma" (CF: 20). La filosofía se tenía a sí misma como objeto, debiendo indagar sobre su propia orientación, dirección; pero tomando distancia de la pregunta por el fin y el origen para no "resucitar la vieja pregunta religiosa acerca del destino que es el complemento de una teoría del origen radical de las cosas" (Ibíd.: 25).

Ahora bien, de acuerdo con Montag (2015) en La corriente subterránea, el acto de tomar distancia es sustantificado, ontologizado: el vacío no se ejerce, sino que se

\footnotetext{
${ }^{54}$ Para quien "el discurso se presenta como una transcripción instantánea del pensamiento a un sistema convencional de sonidos y, como tal, sufre menos interferencia del cuerpo que otras acciones" (Montag, 2015: 8).

${ }^{55}$ Matheron incluye una nota que señala que, en ese mismo año, 1982, Macherey define una paradoja del mismo tipo.

${ }^{56}$ Vittorio Morfino (2014) señala al respecto que "la filosofía -cuya esencia sería el vacío para el Spinoza de Althusser- sería la constatación del encuentro" (p. 75). De manera que la Filosofía será en este marco, la constatación del hecho o asalto del poder ("constatación del hecho o del encuentro").
} 
posee o se representa en la forma de la nada. Así, la filosofía tiene un objeto externo: la nada que es el origen y destino de todas las cosas. De acuerdo con esta lectura, si la filosofía crea un vacío no lo hace para ocupar un espacio sino para desvelar el vacío hasta ahora escondido que no sólo precede, sino que acompaña como una sombra a todo lo que existe a modo de su secreto y de su verdad. Esta concepción ontológica del vacío, como debemos llamarla, se convierte para Althusser, en la característica definitoria, la diferencia específica de "aquella profunda tradición" que lleva desde Epicuro hasta Marx” (Montag, 2015: 7). Que la filosofía no tenga objeto, y que, en ese sentido sea una oposición al abordaje tradicional de la práctica filosófica ("antifilosofía"), queda manifiesta en la siguiente cita:

Si quisiéramos ceñirnos más estrechamente a estas tesis, tendríamos que producir un cierto número de conceptos que, naturalmente, serían conceptos sin objeto, al ser los conceptos de nada, y la filosofía, al no tener objeto, transformaría esta nada en ser o en seres, de tal modo que, por medio de dicha transformación, la filosofía llevaría a esta nada a ser desconocida y reconocida en ellos (que es por lo que dicha nada fue, en última instancia, desconocida y presentida).

Con la afirmación de la nada y el consecuente rechazo a la postulación de un origen, Althusser abre el espacio para el reconocimiento de una realidad fuera de la cual "no hay nada", en la que nos constituimos como tales mediante mecanismos de la realidad misma, como lo es la ideología, como las condiciones ideológico- discursivas de las relaciones de producción. En ese sentido, la interpelación ideológica- la función central de la ideología encargada de constituir individuos en "sujetos"- constituye en realidad, una interioridad subjetivada que es la continuidad de la exterioridad.

De manera que, podemos sostener que, el materialismo aleatorio, así como todo el posicionamiento materialista transversal de Althusser no es el de un "sujeto", sino el de un proceso que impone a los "sujetos" a los que domina, el orden de su desarrollo "sin un fin asignable" (ME: 55- 56). En la segunda parte, nos centraremos en las tensiones entre subjetivación/ sujeción; por el momento continuamos con el desarrollo de la filosofía de la nada bajo la que deberíamos "producir un cierto número de conceptos que serían conceptos sin objeto, al ser los conceptos de nada, y la filosofía al no tener objeto, transformaría esta nada en ser o en seres, de tal modo que, por medio de 
dicha transformación, la filosofía llevaría a esta nada a ser desconocida y reconocida en ellos" $" 57$.

En esta dirección, Althusser afirma que en la "nada" de la desviación tiene lugar el encuentro entre un átomo y otro, y este acontecimiento deviene advenimiento (...). De ahí la forma de orden y la forma de seres cuyo nacimiento es provocado por esta carambola, determinadas como están por la estructura del encuentro. El carácter aleatorio de la toma de consistencia de este encuentro "da lugar al hecho consumado del cual pueden enunciarse leyes" (Ibíd.: 65). Marx, según la lectura de Althusser, nos habla frecuentemente de este encuentro (Das Vorgefundene) entre el "hombre de los escudos" y la fuerza de trabajo desnuda.

Lo que refuerza el materialismo aleatorio es la tesis de la primacía de la estructura por sobre sus elementos. La estructura precede a sus elementos y los reproduce para reproducir la estructura. En este sentido, señala Althusser siguiendo a Marx, que un modo de producción es una estructura que impone a todos sus elementos su unidad; bajo un modo de dominación. Lo que importa en el modo de producción, más que tal o cual hecho, es el modo de dominación dela estructura sobre sus elementos. En este sentido,

en el modo de producción feudal, es la estructura de dependencia la que impone su sentido a los elementos: la posesión, por parte del señor, de la hacienda (incluidos los siervos que trabajan en ella) y de los instrumentos colectivos (el molino, la granja, etc.), el papel subordinado del dinero, hasta el momento en que las relaciones monetarias se impongan a todos.

Así, en el modo de producción capitalista, la estructura de explotación se impondrá a todos sus elementos, la subordinación de los medios de producción y de las fuerzas productivas al proceso de explotación, la explotación de los trabajadores despojados de medios de producción, el monopolio de los medios de producción en las manos de la clase capitalista, etc.

(ME: 71).

Bajo esta línea de análisis, en El materialismo aleatorio...Althusser afirma que, una vez efectuado el encuentro (pero no antes), se da la primacía de la estructura sobre sus elementos, la que los antecede y los reproduce; porque estos tienen "capacidad para engancharse", "para cuajar" (Ibíd.: 35). Pero "cualquier cosa no puede producir

\footnotetext{
${ }^{57}$ Cabe aquí recordar el vínculo que el pasaje anterior tiene respecto del tratamiento del problema del sujeto que Althusser realizara en los AIE donde el reconocimiento ideológico tiene como reverso el desconocimiento.
} 
cualquier cosa", sino que hay elementos condenados a su encuentro y por su afinidad a "tomar consistencia". Sin embargo, Althusser también señala que el encuentro puede no tener lugar, puede fracasar. De allí que "el Príncipe debe aprender a gobernar su fortuna gobernando a los hombres. Debe estructurar su Estado formando en él a los hombres y, sobre todo, dotándolo de leyes constantes" (Ibíd.: 38). Pero hay una condición para ello: el encuentro debe durar para que realmente haya existido; debe perdurar para que la figura del Príncipe tome consistencia, o el capitalismo, o la estructura patriarcal.

En cuanto a la toma de consistencia del capitalismo, el carácter aleatorio de la toma de consistencia de este encuentro que da lugar al hecho consumado del cual pueden enunciarse leyes" (Ibíd.: 65), no es anterior a la "toma de consistencia", sino posterior; de modo que podría no haber tomado consistencia y no tener lugar. Althusser extrema la tesis y señala que: "Podríamos incluso ir más lejos y suponer que el encuentro ha tenido lugar en la historia en numerosas ocasiones antes de su "toma de consistencia" occidental, pero debido a la falta de un elemento, o de la disposición de los elementos, no "tomó consistencia"” (Ídem).

Entonces bien, el encuentro podría no haber tenido lugar. En el caso del modo de producción capitalista (siendo el concepto de producción -en la lectura de Marx por Althusser- un concepto que permite tanto pensar en toda formación social, como así también, periodizar la historia), nos encontramos ante el hecho consumado de este encuentro:

provocando relaciones estables y una necesidad cuyo estudio proporciona 'leyes', evidentemente tendenciales: las del desarrollo del modo de producción capitalista (ley del valor, del intercambio, ley de las crisis cíclicas, ley de la crisis y la descomposición del modo de producción capitalista, ley de transición al modo de producción socialista, etc.). Lo que importa en esta concepción no es tanto el derivar las leyes, digamos, de una esencia, sino el carácter aleatorio de la 'toma de consistencia' de este encuentro que da lugar al hecho consumado, del cual pueden enunciarse leyes.

Por tanto, el todo del encuentro del modo de producción capitalista no es anterior a la "toma de consistencia", sino posterior, puesto que un modo de producción es una combinación particular entre elementos (elementos que son la acumulación financiera, de los medios técnicos de producción, de la materia de producción y de los 
productores). Althusser refuerza su argumentación señalando que estos elementos no existen en la historia para que haya un modo de producción capitalista, dado que la historia no es teleológica, totalitaria y con fines ya predeterminados (la desviación de átomos es una hermosa metáfora para mostrar esto), por lo cual el todo estaría consumado de antemano, sino que "la estructura precede a sus elementos y los reproduce para reproducir la estructura" (Ibíd.: 70).

Retomando la definición de Balibar del modo de producción como una doble combinación de los medios de producción y de las relaciones de producción, Althusser sostendrá que "aquello que constituye entonces al modo de producción es una combinación que somete las fuerzas productivas (los medios de producción, los productores) a la dominación de una totalidad, en la que son los propietarios de los medios de producción los que son dominantes (...) un modo de producción es una combinación porque es una estructura que impone su unidad a una serie de elementos" (Ibíd.: 71).

Recordemos que para Althusser, lo que tiene mayor relevancia es el modo de dominación de la estructura sobre sus elementos. En el modo de producción capitalista, "la estructura de explotación se impondrá a todos sus elementos, la subordinación de los medios de producción y de las fuerzas productivas al proceso de explotación, la explotación de los trabajadores despojados de medios de producción, el monopolio de los medios de producción en las manos de la clase capitalista, etc.”. (Ídem). Esta tesis del materialismo del encuentro puede ser leída en continuidad con un problema que ya fuera planteado en 1966 en la correspondencia de Althusser con Renée Diatkine, como se puede observar en la siguiente cita de la carta 2:

...Se trata del problema del mecanismo del surgimiento de un modo de producción determinado, el modo de producción capitalista. Cuando leemos con un poco de atención $E l$ Capital parece que, contrario a la ideología genética comúnmente aplicada a Marx (o, lo que es lo mismo, a la ideología evolucionista), el modo de producción capitalista no fue engendrado por el modo de producción feudal como su propio hijo. No hay filiación en el sentido propio (preciso) entre los modos de producción feudal y capitalista. Este último surge del encuentro (de nuevo, uno de sus conceptos que apoyo por completo) de un cierto número de elementos muy precisos, y de la combinación específica de estos elementos (...) el modo de producción feudal no engendra de ninguna manera el encuentro de estos elementos, ni el hecho de que puedan combinarse, organizarse en una unidad que funcione (...) que es propiamente lo que surge... 
La cita anterior correspondiente a la segunda Carta a $D \ldots$, Althusser continúa siguiendo lo trazado por Spinoza en su recorrido por el que escapa de toda teoría del conocimiento, es así que propondrá: "nada de moral ni, sobretodo, de religión, o mejor, una teoría de la moral y la religión que mucho antes de Nietzsche, las destruye hasta sus fundamentos imaginarios de la 'inversión' (...) nada de finalidad, queda sólo el vacío que es la propia filosofía"58 (ME: 44). Este vacío abre la vía al reconocimiento del "mundo" tal como está "más allá del cual no hay nada", "como totalidad única no totalizada, sino vivida en su dispersión, y vivida como lo "dado" en la que somos arrojados, y a partir de lo cual nos forjamos todas nuestras ilusiones (fabricae) (Ídem.). En la segunda parte nos enfocaremos a examinar la importancia que tiene para la presente investigación la conceptualización de Spinoza de la imaginación entendida no como facultad, sino como el mundo de lo "dado", al que somos arrojados, y a partir del cual nos forjamos todas nuestras ilusiones que garantizan la servidumbre.

\footnotetext{
58 Para Montag, ante el riesgo de que haya encuentros que se prolonguen eternamente, Althusser debe postular un origen, un abismo original del que todo proviene y a lo que todo retorna, la "inestabilidad radical" que acosa a las estructuras entretejidas.
} 


\section{Conclusiones Preliminares}

La filosofía representa la lucha de clases en la teoria, es decir, la política.

(Althusser, Ser marxista en filosofia)

En la primera parte de este trabajo exploramos la intervención materialista de Althusser en la que ocupa un lugar central la lectura filosófica que propone del pensamiento de Marx; con el fin de rehabilitar conceptos centrales de la teoría marxistay con ello reemplazar las lecturas ideológicas que obturan su novedad.

Hemos examinado que, la lectura filosófica que propone Althusser en Para leer el Capital busca dar cuenta de determinados conceptos "científicos" en la teoría marxista, y con ello reemplazar las lecturas ideológicas que obturan su novedad. Realizar una lectura filosófica de El Capital es, como examinamos, todo lo contrario de una lectura inocente. Es una lectura culpable, capaz de producir una serie de lecturas dobles, aquellas que advierten nuevas problemáticas en las discontinuidades de un discurso. Bajo este protocolo de lectura, Althusser plantea un corte epistemológico en el pensamiento de Marx, entre una problemática ideológica y una problemática científica; esta última consiste en la invención por parte de Marx del método materialista dialéctico y su concepción de la contradicción sobredeterminada.

Para Althusser, lo que ocurre en el caso del desarrollo del pensamiento de Marx, es un "cambio de terreno" una inscripción de los problemas filosóficos en un marco materialista. En el caso de la cuestión de la ideología -que en el Joven Marx estaría inscripta en una perspectiva precientífica- Althusser propone inscribirla en bases materialistas, tras leer el anuncio de esta inscripción en tesis materialistas que se encuentran en La ideología alemana (como la que sostiene que, "no es la conciencia la que determina la vida, sino a la inversa).

Con este cambio de terreno, de problemática, que Althusser ve en el pensamiento de Marx; y en lo referente a la ideología, a partir de los textos de ruptura de 1845; Althusser establece una importante demarcación con los tratamientos ideológicos de la ideología, que implica combatir las interpretaciones humanistas e historicistas del pensamiento de Marx, en las que subyace -según Althusser- una concepción de tipo idealista del sujeto, entendido como central.

Hemos examinado que para Althusser la ideología humanista responde a los intereses de la burguesía en ascenso; y que tiene la pretensión teórica de explicar la 
sociedad y la historia, partiendo de la esencia humana de un sujeto al que supone libre, de la acción moral y de la política.

Entonces bien, frente a la ideología del humanismo teórico que funciona en articulación con el ideal burgués de la libertad humana, y que enmascara las razones profundas de crisis del marxismo; Althusser postula la tesis del antihumanismo teórico de Marx. Se trata de una tesis polémica -heredera del antihumanismo de Spinoza- que implica el rechazo a las pretensiones de otorgarle a la categoría de "sujeto" un estatuto fundamental, como lo hace según Althusser, la gran tradición de la filosofía de tipo idealista. Hecha esta demarcación con los abordajes idealistas, Althusser propone indagar en torno a los mecanismos de la ideología que estrecha vínculos con la estructura social, al responder a las demandas de las clases dominantes. Esta cuestión ha sido planteada en esta primera parte, pero la hemos desarrollado exhaustivamente en la segunda.

Ahora bien, examinamos también, que desde 1963 Althusser postula que la ideología constituye una estructura esencial en la vida histórica de las sociedades. Y afirma que el reconocimiento de este estatuto central de la ideología puede permitir actuar sobre ella y transformarla en un instrumento de liberación y emancipación. Lo que se condice con su propuesta materialista de concepción de la ideología como una práctica que tiene una función social.

Hemos explorado en este sentido que, tanto en Marxismo y humanismo como en los textos de autocrítica, Althusser enfatiza la función práctica y social de la ideología, que constituye una de las tesis centrales de su teoría materialista de la ideología. La tesis de la existencia material de la ideología tomará formas precisas en las Tres notas... y en Ideología y aparatos ideológicos del Estado -que se analizará específicamente en la segunda parte- en los que Althusser plantea una articulación fundamental entre ideología y estructura social. En rechazo al abordaje ideológico de la ideología, que ubica las concepciones del hombre, sus ideas en el ámbito de la conciencia. Para Althusser la ideología no corresponde al ámbito de la conciencia, sino que tiene una dimensión imaginaria, con efectos prácticos. De hecho, la ideología tiene para Althusser, muy poco que ver con la conciencia, sino que funciona de manera profundamente inconsciente, aun cuando parece reflexiva. Como en el materialismo de lo imaginario de Spinoza.

Examinamos que, el abordaje idealista de la ideología es subsidiaria según Althusser, de una teoría del conocimiento, en la que el conocimiento es el producto de 
una relación preestablecida entre sujeto y objeto. Para Althusser, siguiendo a Marx y a Spinoza, el conocimiento es el resultado de un proceso de producción que no tiene a un sujeto como agente central, sino que se produce mediante mecanismos de la práctica teórica. El proceso de conocimiento, dice Althusser parafraseando a Marx, es el conocimiento de un objeto real e implica un proceso de producción a través de tres generalidades (herederas de los tres tipos de conocimiento en Spinoza). Pero este proceso se da "en el pensamiento" es decir, no se deduce del objeto real, no es su fenómeno ni está contenido en su interioridad, sino que es un objeto distinto. En este sentido, así como Spinoza distingue entre la idea de círculo y el círculo real, Althusser distingue, siguiendo a Marx, entre el objeto de conocimiento y el objeto real.

Efectivamente, en el nuevo marco, el proceso de conocimiento deja de tener como centro a un sujeto que conoce. Sino que el conocimiento es el resultado de un proceso sin sujeto, que involucra un posicionamiento materialista que postulará el estatuto derivado del sujeto (ideológico) como efecto de los mecanismos que reproducen la formación social. En este sentido, el descentramiento del sujeto y la tesis del proceso sin sujeto, refuerzan el rechazo de concebir un sujeto originario de sus necesidades (homo economicus) de sus pensamientos (homo rationalis) de sus actos y de sus luchas (homo moralis, juridicus et politicus).

Este planteo se vincula estrechamente con la concepción de las formaciones sociales como complejos estructurados en las que se articulan múltiples instancias y en las que la economía es la que las determina en última instancia. Hemos examinado que, atendiendo a la Introducción de 1857 de Marx, Althusser enfatizará que lo concreto es la síntesis de múltiples determinaciones de las relaciones en las cuales los sujetos no son constituyentes, sino un efecto de estas relaciones de producción; que son siempre relaciones de lucha de clases. En las formaciones sociales como un todo complejo estructurado entonces, se articulan múltiples instancias, y "el sujeto" es descentrado y comprendido como una categoría derivada.

La concepción del "todo complejo estructurado con dominante" y de la determinación en última instancia por la economía, son centrales para comprender el funcionamiento de la ideología, que deja de ser pensada como abstracción, como exclusiva del ámbito de la conciencia y del mero pensamiento para ser comprendida como una práctica con efectos materiales. En este sentido, hemos examinado que, en el análisis propuesto por Althusser, existe una relación necesaria entre el sujeto y la ideología, cuya estructura de la interpelación- garantía es la que produce el efecto de 
subjetividad ideológica. La identificación del carácter ideológico de la noción de sujeto, parte ahora de la pregunta por sus efectos políticos, redoblando así, la perspectiva histórica ya que involucra la tesis de que la lucha de clases es el motor de la historia, lo cual rompe con la categoría del Sujeto como Origen, Esencia y Causa,

La concepción de la historia como un proceso sin sujeto y la teoría de la ideología desde bases materialistas, encuentran su conexión en la idea de que la ideología es la forma en la que hombres y mujeres se constituyen para formar parte de un proceso del cual no son los creadores. La tesis de la historia como un proceso sin sujeto ni fines, Althusser la expone centralmente en sus textos de autocrítica. En esos textos, además, Althusser rectifica su distinción tajante entre ciencia e ideología para reconocer rupturas epistemológicas diversas (al diferenciar entre ideologías teóricas, ideologías prácticas, etc.). Subsidiariamente, Althusser rectifica su posición teoricista al plantear la politicidad de la práctica teórica. Es en este marco que propondrá una nueva práctica de la filosofía: como lucha de clases en la teoría, Kampfplatz.

Por otra parte, hacia el final de esta primera parte, exploramos que en los textos del materialismo aleatorio -del "último Althusser"- existe una continuidad de tesis materialistas que se encuentran en los textos del Althusser clásico. Con lo cual, nos posicionamos contra las interpretaciones que leen un corte (Kehre) al interior de la producción althusseriana. Desde nuestra perspectiva, existe en Althusser, una transversalidad de una posición filosófico- materialista. Sin embargo, plantear esta continuidad no implica entenderlo de manera monolítica, al contrario, atendiendo a que las rectificaciones, los rodeos, los recomienzos, los retornos, y las polémicas, son formas propias del filosofar althusseriano. Entender esta particularidad en la práctica filosófica propuesta por Althusser, es una comprensión muy distinta de aquellas concepciones que interpretan cortes y virajes "último Althusser", respecto de sus posicionamientos anteriores.

Bajo nuestra lectura, en la intervención de Althusser existe una transversalidad de tesis materialistas centrales, que pueden ir tomando formas diversas a lo largo de su obra, como lo son: a) su propuesta de una práctica filosófica de la lectura; b) su crítica al abordaje idealista de las filosofías del sujeto (antihumanismo teórico) y el rechazo a toda idea de Origen y de génesis (materialismo aleatorio); c) consecuentemente, el rechazo al tratamiento idealista de la ideología; d) la propuesta de causalidad estructural y de contradicciones sobredeterminadas; e) la propuesta de las formaciones sociales como estructuras complejas con una multiplicidad de instancias articuladas y 
determinadas en última instancia en las que el "sujeto" no ocupa más que un lugar secundario; y f) la propuesta filosófica de Althusser de practicar una nueva filosofía en la que existe una primacía de la práctica por la teoría. 
PARTE II. IDEOLOGÍA Y SUBJETIVACIÓN 


\section{Capítulo IV. Hacia una teoría materialista de la ideología}

Es en la lucha de clases dentro de la ideología que va a decidirse y se decide ya el porvenir de la lucha de clases en general. (Althusser, Tesis de Amiens)

En este capítulo proponemos mostrar que la propuesta de Althusser de comprender la ideología desde su existencia material, profundamente imbricada con la estructura social, constituye una demarcación con los tratamientos de tipo idealistas que la conciben como una representación falseada de la realidad material.

Explorar los mecanismos de subjetivación de la ideología concebida desde su naturaleza material e imaginaria, así como su estructura y sus articulaciones con otras estructuras como la del inconsciente, constituye el objetivo central de ese capítulo.

Subsidiariamente, pretendemos mostrar que, la inscripción de la ideología en bases materialistas implica también un "cambio de terreno" del concepto de "sujeto", que será comprendido como un efecto de estructuras en el que intervienen los mecanismos de subjetivación/ sujeción. En este sentido, mostraremos que al plantear una pregunta no formulada: “¿cómo se constituyen los individuos en sujetos?" Althusser repone un silencio respecto de los abordajes idealistas que dan por supuesto al "sujeto", y subsidiariamente, refuerza su propuesta "de combatir al Sujeto de todos sus disfraces" ${ }^{, 59}$ (Aguilar Rivero, 1984: 55).

\footnotetext{
${ }^{59}$ Profundizando el rechazo transversal de la categoría idealista de "sujeto" constituyente (sea a través de la tesis del antihumanismo teórico, o a través de las tesis del conocimiento y de la historia como procesos sin sujeto ni fines).
} 


\section{La reformulación de la ideología de Althusser}

¿Qué es la ideología? ¿Puede traducirse en función de ella la lógica de sobrevivir que acabamos de vislumbrar con respecto al patrimonio del ídolo y cuál sería el interés de semejante operación? (Jacques Derrida, Espectros de Marx)

En Ideología y aparatos ideológicos del Estado -publicado originalmente en el órgano comunista La Pensée en junio de 1970, y extractado de un escrito que lleva a mano el título "De la superestructura" fechado en enero-abril de 1969; que luego será editado por Jacques Bidet y publicado bajo el título Sobre la Reproducción ([1995] 2015)- Althusser efectúa una demarcación con la concepción idealista de la ideología (de la que quedarían resabios en La ideología alemana de Marx y Engels) al inscribir el concepto en una perspectiva materialista.

En este ensayo Althusser propone reformular el concepto de ideología al caracterizarla como: "la representación imaginaria de la relación material que los individuos tienen con sus condiciones de existencia” (IAEI: 45). La ideología será, en el nuevo marco, una representación fiel de la relación necesariamente imaginaria que los individuos mantienen con sus condiciones reales de vida.

En este nuevo marco, no cabe ya preguntar por el factor de la transposición imaginaria -pregunta que se han hecho distintas interpretaciones: desde el mecanicismo del siglo XVIII cuando sostenía que Dios era la representación imaginaria del Rey real, pasando por la interpretación hermenéutica que inauguran los Padres de la Iglesia y que adopta Feuerbach (para quien Dios era la esencia del hombre real)- donde subyace el supuesto de que "los hombres se representan en forma imaginaria sus condiciones de existencia" (Ibíd.: 44). Para Althusser, este supuesto impide plantear la siguiente pregunta: “¿por qué los hombres 'necesitan’ esta trasposición imaginaria de sus condiciones reales de existencia para 'representarse' sus condiciones de existencia reales?" (Ídem).

Al indagar en esa dirección, Althusser sostiene que es "la naturaleza imaginaria de esa relación es la que sostiene toda la deformación imaginaria" (Ibíd.: 46), es decir que, en esa relación necesariamente imaginaria que los individuos tienen con sus condiciones de vida, está contenida la "causa" que debe dar cuenta de la deformación imaginaria. Lo cual implica una demarcación con la concepción de la ideología, según la cual, se supone que la creencia que un individuo tiene (en Dios, en la Justicia, etc.) 
depende de las ideas que el individuo escoge libre y conscientemente, ya que reduce la ideología a ideas con existencia espiritual.

En el marco de la reformulación propuesta por Althusser, la naturaleza imaginaria de la ideología manifiesta que, el objeto representado en la ideología (tesis negativa) no son las relaciones de producción y las relaciones que de ella resultan -que gobiernan y determinan la vida de los individuos- sino que lo representado es ante todo la dimensión imaginaria que experimentan los individuos con sus condiciones de existencia como sujetos. La ideología es así, una representación necesariamente mistificada del todo social, donde la necesariedad de esta mistificación tiene como factor "la opacidad del todo social en tanto "determinado por su propia estructura" (PLC: 56). Mientras que la naturaleza material consiste en que la ideología tiene existencia material (tesis positiva) ya que se trata de ideas que existen en los actos de los individuos, los que a su vez están inscritos en prácticas reglamentadas por rituales, que se realizan al interior de un aparato ideológico determinado. Althusser, aclara aquí, que "obviamente", la existencia material de la ideología en un aparato y sus prácticas, no posee la misma materialidad que una baldosa o un fusil; sin embargo, hay que tener en cuenta, siguiendo a Aristóteles que "la materia se dice de muchas maneras", existe en diversas modalidades, arraigadas en última instancia en la materia "física" (IAEI: 48).

Ahora bien, no podemos dejar de tener en cuenta que, al reformular el estatuto de la ideología, su naturaleza epistemológica, y sus alcances, Althusser también reformula la topografía ${ }^{60}$ marxista de la metáfora espacial del edificio compuesto por una base (infraestructura) sobre la que se levanta la superestructura. Esta metáfora, sostiene Althusser, tiene por objeto representar ante todo la "determinación en última instancia por medio de la base económica", cuyo índice de eficacia es pensado bajo dos formas: 1) existe una "autonomía relativa" de la superestructura con respecto a la base; 2) existe una "reacción" de la superestructura sobre la base. Sin embargo, Althusser advierte que esta representación topográfica tiene limitaciones, y que si se adopta el punto de vista de la reproducción es posible pensar en la naturaleza de la superestructura.

${ }^{60} \mathrm{En} \mathrm{n} / \mathrm{t}$ se aclara que "una topografía representa, en un espacio definido, los lugares respectivos ocupados por tal o cual realidad: así, el económico está abajo (la base), la superestructura arriba. Hace, pues, visible lo que está en el fundamento (la base) y lo que está determinado por la base (la superestructura). Cualquiera sabe en efecto, $y$ 've' que los pisos de una casa no se tienen solos en el aire, sino que se 'sostienen' sobre una base y sus fundamentos" (SR: 90). 
Lo que se debe agregar, según Althusser, a la teoría marxista es distinguir entre el poder del Estado y el aparato de Estado (AE); y luego entre aparato represivo del Estado (ARE) y aparato ideológico del Estado (AIE). Al reconocer la existencia material y la eficacia de la ideología a través de los aparatos ideológicos del Estado $(\mathrm{AIE})^{61}$, Althusser amplía el análisis marxista que sólo reconocía la existencia del aparato de Estado que incluye no sólo el aparato especializado (el poder judicial, la policía, los tribunales, las prisiones) sino también el ejército. Y distingue así, entre ideología primaria (del Estado), y la ideología secundaria, como subproducto, en la práctica. En este marco, el Estado es "una 'máquina' de represión”, un ARE. Sin embargo, ninguna clase puede tener en sus manos el poder de Estado en forma duradera sin ejercer al mismo tiempo su hegemonía sobre y en los AIE, ya que:

Un aparato ideológico de Estado es un sistema de instituciones, de organizaciones y de prácticas correspondientes definidas. En las instituciones, organizaciones y prácticas de este sistema, se materializa todo o parte (en general, una combinación típica de ciertos elementos) de la Ideología de Estado. La ideología materializada en un AIE asegura su unidad de sistema en base a un "anclaje" en funciones materiales, propias de cada AIE, que no son reductibles a esta ideología, pero que le sirven de sostén.

El punto preciso de intervención teórica afecta, por consiguiente, a estos AIE en su diferencia con los ARE. Si estos últimos "funcionan mediante la violencia" y comprenden a la administración, el ejército, la policía, los tribunales, las cárceles; los AIE funcionan mediante la ideología (escolar, familiar, religiosa, política, sindical, de la información, de edición- difusión, cultural) y se conforma por instituciones $u$ organizaciones, que forman un "sistema" (Ibíd.: 113).

Ahora bien, moderando la distinción entre ARE y AIE, Althusser señalará que "todo aparato de Estado, sea represivo o ideológico, combina a la vez, el funcionamiento con la represión y el funcionamiento con la ideología (SR: 208). Pero lo hacen con una diferencia muy importante que impide confundirlos: los ARE, funcionan masivamente con la violencia y la represión como forma predominante; mientras que los AIE funcionan con la ideología como forma predominante.

\footnotetext{
${ }^{61}$ La noción de "aparato ideológico de Estado" es deudora, según Althusser, de la teoría de Gramsci"que tuvo la singular idea de que el Estado no se reducía al aparato represivo de Estado, sino que también comprendía, según sus términos, cierto número de instituciones de la sociedad civil” (IAEI: 91).
} 
En ese sentido, se reconoce que el ejército y la policía utilizan también la ideología, tanto para asegurar su propia cohesión y reproducción, "como por los valores que ambos proponen hacia afuera" (ídem). Incluso aparatos que parecen puramente ideológicos, tales como la escuela y la iglesia "utilizan métodos propios del castigo, la expulsión y la selección, etc., para disciplinar no sólo a sus pastores sino también sus rebaños" (ídem).

Por otra parte, si los ARE constituyen un todo organizado y se rigen bajo el poder de quienes detentan el poder de las clases dominantes; los AIE son múltiples, "relativamente autónomos", "susceptibles de ofrecer un campo objetivo de contradicciones que expresan los efectos de los choques entre la lucha de clases capitalista, y la lucha de clases proletaria, como sus formas subordinadas" (IAEI: 30). La unidad entre los diferentes AIE estaría asegurada por la ideología de las clases dominantes. Althusser señala que, si se tienen en cuenta estas características, se puede representar la reproducción de las relaciones de producción como una especie de división del trabajo, en la que los ARE aseguran su propia reproducción, pero aseguran también mediante la violencia, las condiciones políticas de la actuación de los AIE. Y estos últimos "bajo el escudo de los ARE", aseguran la reproducción misma de las relaciones de producción.

\section{La reproducción de las relaciones de producción}

Y como la relación de producción es una lucha de clases, es la lucha de clases la que determina en última instancia las relaciones de la superestructura, sus contradicciones y la sobre determinación con las que marcan la infraestructura. (Althusser, Defensa de Tesis en la Universidad de Amiens)

Ideología y aparatos.... comienza con una famosa cita de la Carta a Kügelmann: "Decía Marx que aún un niño sabe que una formación social que no reproduzca las condiciones de producción al mismo tiempo que produce, no sobrevivirá ni siquiera un año" (IAEI: 9). Por lo tanto, la condición necesaria para que haya producción, es la reproducción de las condiciones de producción. Sin embargo, según Althusser, existe un obstáculo para elevarse al punto de vista de la reproducción (Ídem) que se vincula a que las evidencias (ideológicas, de tipo empirista) están enlazadas únicamente al punto de vista de la producción, e incluso al punto de vista de la práctica productiva (pero 
abstraída del proceso de producción) con lo cual se confunden con nuestra "consciencia" cotidiana.

Entonces bien, dado que toda formación social está determinada y depende de un modo de producción dominante, emplea las fuerzas productivas en y bajo relaciones de producción definidas. De lo que se sigue que, para poder subsistir, "toda formación social debe, al mismo tiempo que produce, reproducir las condiciones de su producción. Debe, por tanto, reproducir: 1) las fuerzas productivas y 2) las relaciones de producción existentes" (Ibíd.: 10). Para ello, se debe asegurar a la fuerza de trabajo las condiciones materiales de su reproducción, a través del salario, para garantizar que se satisfagan necesidades básicas como vivienda, vestimenta, comida; así como se requiere de un mínimo histórico variable: "el alemán necesita cerveza, el francés, vino" 62 .

Sin embargo, para Althusser, no basta con garantizar a la fuerza de trabajo las condiciones materiales de su reproducción para que se reproduzca como tal; sino que además se la debe calificar para que esta pueda ser competente en el sistema de producción. Tendencialmente, señala Althusser, se realiza a través de instituciones del Estado como la escuela, la iglesia, el ejército, los partidos políticos - y otras instancias e instituciones del sistema capitalista, capaces de asegurar la sujeción a la ideología dominante. Puesto que, la condición sine qua non de la reproducción de la fuerza de trabajo no sólo radica en la reproducción de su "calificación" sino que, además, la fuerza de trabajo se reproduce y asegura en y bajo el sometimiento ideológico ${ }^{63}$. Por tanto, se requiere tanto de la "cualificación" de la mano de obra, así como la sumisión de esta a la ideología dominante, mediante la internalización de las normas.

En este sentido, la escuela -(aquella que "tan silenciosa es" (IAEI: 36)- es comprendida por Althusser como el AIE fundamental de las sociedades capitalistas maduras -así como la Iglesia lo era en la Edad Media ya que acumulaba numerosas funciones (en especial las escolares y las culturales) y operaba articulada con el AIE familiar- porque, el aparato ideológico escolar, además de disponer durante varios años, de la asistencia obligatoria de los individuos; está recubierto por una ideología que representa a la escuela como un medio neutro. Ocultando que, es a través de las

\footnotetext{
${ }^{62}$ Silvia Federici (2010) señala que el análisis de Marx en El capital es sesgado ya que es realizado únicamente desde el punto de vista del varón asalariado. Retomaremos esta lectura crítica en la III parte de este trabajo.

${ }^{63}$ Según Althusser, es la práctica de la lucha ideológica y luego, la política, la que obligó a Marx a reconocer desde sus obras de juventud, la existencia y la realidad de la ideología "y la necesidad de su papel en la lucha ideológica y finalmente política: en la lucha de clases" (SR: 210).
} 
prácticas que preescribe el AIE escolar que, una "gran masa" de niños caerá en la producción (son los obreros o los pequeños campesinos); mientras otra parte continuará la escuela y ocupará puestos de comerciantes, funcionarios, etc. Ya que, "cada grupo está provisto de la ideología que conviene al rol que debe cumplir en la sociedad de clases" (Ibíd.: 38).

En la escuela, sostiene Althusser, lo que se aprende además de técnicas como la lectura, la escritura y el cálculo; y de conocimientos de la cultura científica y literaria que funcionan como "destrezas"- son las "reglas del orden establecido por la dominación de clase" (IAEI: 14; SR: 85). El AIE escolar, de esta manera, les inculca a los niños de todas las clases sociales -desde el jardín de infantes- "habilidades" recubiertas de la ideología dominante. Es decir, bajo formas que aseguran el sometimiento a la ideología dominante o el dominio de su "práctica" mediante la sumisión a las reglas del respeto del orden establecido ${ }^{64}$; no ya mediante la fuerza explícita, sino a través de discursos, reglas, ideas y estrategias de dominación de la clase dominante ${ }^{65}$.

Siguiendo por esta línea, no es sólo por medio del aparato represivo que el Derecho burgués puede ejercer su poder, sino que lo puede hacer gracias a la ideología jurídica, y la ideología moral, que le sirven de "suplemento" y que permiten que el Derecho "funcione"; sin recurrir a la represión. Pero, Althusser señala que, si para la práctica del Derecho se requiere la ideología jurídica, no debe confundirse al Derecho con esta última, ya que existe una "pequeña diferencia":

\footnotetext{
${ }^{64}$ Dentro de este Orden se encuentran también, como señala Althusser en Freud y Lacan: "las normas de los ritmos temporales de la alimentación, de la higiene, de los comportamientos, de las actitudes concretas del reconocimiento - la aceptación, el rechazo, el sí o el no al niño, no son más que una pormenorización, las modalidades empíricas de ese Orden constituyente. Orden de la Ley y el Derecho de asignación que atribuye y excluye...” (EP: 40- 41. Citado por Aguilar Rivero, 2019: 64).

${ }^{65}$ Poulantzas (1979) critica que el concepto de "aparato ideológico", remite únicamente a mecanismos coercitivos de inculcación y que, por tanto, el Estado en su conjunto no sería sino una maquinaria que ejerce diversas formas de represión (ideológicas o no). Esta concepción, según Poulantzas, no toma en cuenta los aspectos positivos del Estado. El Estado, dice siguiendo a Foucault, "actúa también de manera positiva, crea, transforma, produce realidades" (p. 30). Para Aguilar Rivero, es cierto que Althusser no desarrolla, como lo hace Poulantzas, el lado positivo de las contradicciones sociales que se juegan en el Estado, pero "su concepción del sujeto como un individuo que realiza "voluntariamente" ciertas prácticas -es decir, la referencia al carácter imaginario de la ideología- alude directamente a los efectos ideológicos estatales de positividad, que tienen que ver con los deseos de los individuos" (Aguilar Rivero, 2019: 65).
} 
El Derecho dice: los individuos son personas jurídicas, jurídicamente libres, iguales y obligadas en cuanto personas jurídicas (...) la ideología jurídica tiene por su parte, un discurso aparentemente similar, pero de hecho completamente diferente. Dice: los hombres son libres e iguales por naturaleza. En la ideología jurídica es, pues, la "naturaleza" y no el Derecho la que "fundamenta" la libertad y la igualdad de los hombres (y no de las personas jurídicas).

La práctica del Derecho señala Althusser funciona en articulación con la ideologia jurídico- moral, esta última ocupa "el lugar del gendarme" (ídem), pero por ello justamente, no es el gendarme. Sino que se trata de una dimensión imaginaria con capacidad de "moldear" a los sujetos para que actúen de determinada manera.

Antes de avanzar en el análisis de la naturaleza material de la ideología, su estructura, mecanismos de funcionamiento, materia prima y efectos, cabe hacer dos señalamientos importantes: 1) por un lado, cuando Althusser reformula el concepto de ideología, destierra el concepto de ideas, pero mantiene los conceptos de "sujeto", “creencia", "actos" y "conciencia" (Ibíd.: 51) ${ }^{66}$, todos términos vinculados a la interioridad. Sin embargo, Althusser los emplea subvirtiendo su significado, al inscribirlos en una "teoría no subjetivista de la subjetividad" 67.

En este sentido, cabe señalar, a modo comparativo que, si para Althusser se trata de sostener que "toda ideología interpela a los individuos concretos en sujetos"; para Foucault, de manera análoga, es preciso estudiar "la manera en que un ser humano se transforma en sujeto" (cfr. Le Blanc, 2006: 45). En ambos casos, el sujeto se halla determinado y definido por un tipo de relación de poder, sea la ideología o la disciplina,

\footnotetext{
${ }^{66}$ André Tosel, en el Crespúsculo de la servidumbre (1984) llama la "estrategia del sive" a la estrategia que consiste en permanecer dentro del régimen conceptual dominante al tiempo que se desarrolla una operación de transformación teórica y de traducción: Dios o la naturaleza, el derecho o el poder, mantener las palabras al tiempo que se cambian los significados y, entonces, volver estas palabras en contra de ese régimen.

${ }^{67}$ De acuerdo con la lectura althusseriana que ya hemos examinado en la Parte I, es principalmente a partir de La ideología alemana, que Marx habría comenzado a prestar atención al estatuto de la ideología, y a otorgarle un estatuto central en todas las dimensiones de las formaciones sociales. Sin embargo, existen en esa obra de 1845 resabios idealistas que, para Althusser en última instancia se deben a que la ruptura es efectuada con los términos mecanicistas y positivistas con los que disponía en ese momento (así como la ruptura que efectuara Freud, se realizara con los elementos biologicistas), pero utilizados sólo como palabras y no como conceptos teóricos. De un modo completamente distinto lee Butler (2011) la utilización althusseriana del término "conciencia". Para la autora esta utilización compromete al ensayo de Althusser con la ideología religiosa, por tanto, restituye un sentido de ideología que se supone que el autor debía desandar.
} 
que "lo somete marcándolo corporal y mentalmente" (Ídem) ${ }^{68}$. Sin embargo, a diferencia de Foucault que rechaza el concepto de ideología, porque le parecía imposible que pudiera disociarse de algún tipo de existencia inmaterial o ideal, fueran las ideas o la conciencia (a las que les niega cientificidad) ${ }^{69}$; Althusser intenta, paradójicamente "minar el concepto ideológico de la ideología" con la categoría misma de ideología, pero inscripta en una perspectiva materialista.

Por otro lado, y en profunda relación con lo anterior cabe señalar que, 2) Althusser destierra cualquier noción de interioridad, o más bien muestra que lo interior está ya siempre inscripto en la exterioridad fuera de la cual no puede existir ${ }^{70}$.Ya hemos argumentado que la ideología no es comprendida por Althusser como una presencia ilusoria a la que la materialidad del cuerpo con el que pensamos podría oponérsele" (Montag, 2009: 162). Sino que el interior "interpelado" es constituido por el exterior, del que es una continuación. Por tanto, en el marco del análisis althusseriano sólo habría exterioridades; con lo cual, las ideas, las creencias y la conciencia son siempre inmanentes a la irreductible materialidad de los discursos, las acciones, las prácticas, y "las ilusiones imaginarias". De acuerdo con el "materialismo de lo imaginario" de Spinoza -así llamado por Althusser por primera vez en Elementos de autocrítica- si pensamos, lo hacemos con y en nuestros cuerpos; con lo cual no hay lugar para los actos internos que supuestamente suceden dentro de la interioridad y de la conciencia, sino que esta es profundamente material y asegura la servidumbre de los hombres.

\footnotetext{
${ }^{68}$ Sin embargo, en El poder psiquiátrico. Curso en el Cóllege de France (1973- 1974) Foucault toma distancia explícitamente del planteo de Ideología y aparatos... al sostener que "no es la familia, no es tampoco el aparato de Estado (...) los que sirven de fundamento en esas relaciones de poder que estamos en condiciones de señalar en el interior de la práctica psiquiátrica (...) en tanto productoras de una serie de enunciados que se presentan como enunciados legítimos (...) Me gustaría más hablar de microfísica del poder, en vez de hablar de institución, me gustaría más tratar de ver cuáles son las tácticas puestas en acción en esas prácticas que se enfrentan; en lugar de hablar de modelo familiar o de 'aparato del Estado', querría intentar ver la estrategia de esas relaciones de poder y esos enfrentamientos que se despliegan en la práctica psiquiátrica" (Foucault, 2007: 33-34). En esa misma dirección, en La sociedad punitiva (19721973) Foucault afirma que "el aparato de Estado es una forma concentrada e incluso una estructura de apoyo de un sistema de poder que va mucho más allá y es mucho más profundo" (Foucault, 2016: 245).

${ }^{69}$ En Las Palabras y las Cosas ([1966] 2010) Foucault señala que las ciencias del hombre "forman parte de la episteme moderna (...) Pero decir que forman parte del campo epistemológico significa tan sólo que su positividad está enraizada en él, que allí encuentran su condición de existencia; que, por tanto, no son únicamente ilusiones, quimeras seudocientíficas, motivadas por el nivel de las opiniones, de los intereses, de las creencias... no son lo que otros llaman, usando un nombre caprichoso, 'ideología'. Pero, a pesar de todo, esto no quiere decir que sean ciencias" (Foucault, 2010: 377).

${ }^{70}$ Así como más adelante veremos que, gracias al concepto de inconsciente del psicoanálisis, Althusser logra eludir a la interioridad subjetiva. Sin embargo, utiliza un término: el de in- consciente que se construye en oposición a la conciencia (es decir, nuevamente, el lenguaje obsoleto para dar cuenta de un descubrimiento teórico).
} 


\section{El "materialismo de lo imaginario" de Spinoza}

...la vida de su gente era una larga educación en la obediencia... nadie deseaba lo prohibido sino lo preceptuado. (Montag, El alma es la prisión del cuerpo)

De acuerdo con la lectura althusseriana, en el marco de la teoría materialista de Spinoza, la imaginación es pensada desde sus efectos materiales, y existe la potencia “de pensar propiamente con el cuerpo" (UTM: 140). Esta "potencia del cuerpo de pensar", es presentada por Spinoza, según Althusser, en su teoría del paralelismo de los atributos, en la que se afirma que nuestro cuerpo material ("del que no conocemos todas las potencias") está animado por la potencia esencial del conatus -que anima también el estado correspondiente de la mens (que no es alma ni espíritu sino la potencia, la fortitudo, la virtus de pensar)" (Ibíd.: 139)- tal como da cuenta la siguiente cita:

... el alma (la "mens", la actividad del espíritu) no está separada en ningún modo de la actividad del cuerpo orgánico; por el contrario, el alma sólo piensa en la medida en que es afectada por las impresiones y movimientos del cuerpo, que, por tanto, no sólo piensa con el cuerpo sino en él, consustancialmente unida a él antes de cualquier separación, puesto que esta unión, que jamás constituye un problema, contrariamente a lo que sucede en Descartes, se funda en la infinidad de los atributos de la substancia y su paralelismo estricto.

(UTM: 143)

Entonces bien, lo que destaca Althusser en su lectura es que, para Spinoza, la mente y el cuerpo, son simultáneos e inseparables, y están determinados por las mismas causas: "cualquier cosa que disminuya o limite el poder de actuar del cuerpo, simultáneamente reduce el poder de pensar de la mente (E, III, prop. 11). Con lo cual la ontología spinoziana subvierte completamente la ontología de la concepción moderna (hegemónica) en la que la corporalidad ocupa un lugar de inferioridad en relación a su opuesto jerárquico: la razón ${ }^{71}$.

Estas dicotomías jerárquicas y binarias son propias de la lógica occidental moderna que, -caracterizada por un espíritu racionalista- coloca al cogito en el centro del conocimiento y concibe al cuerpo como materia inerte, completamente separada de

\footnotetext{
${ }^{71}$ Esta crítica a la modernidad colonial y su lógica dicotómica y binaria es retomada en la III parte de este trabajo a partir de las propuestas de teóricas feministas anticapitalistas, antirracistas y anticolonialistas. No podemos dejar de señalar en esta dirección, que la propuesta de Spinoza también es leída críticamente por su equivoco en torno a la condición de la mujer.
} 
la actividad racional; cuyo funcionamiento mecánico - desde la circulación de la sangre, hasta el habla- es identificado con el modo de funcionar de la naturaleza, con la que compartirían las mismas leyes físicas. Si adherimos a esta tesis, tiene sentido examinar a modo comparativo que, si para Descartes "nada obra más en contra de nuestra propia alma que nuestro propio cuerpo, de modo tal que cuando el cuerpo actúa, el alma padece y viceversa" (Descartes, 1963: 72); Spinoza se demarca del planteo tradicional del conocimiento y postula el paralelismo de un cuerpo no sustancial, sino relacional que para subsistir necesita del intercambio con otros cuerpos, siempre atravesados por "lo imaginario".

En efecto, subvirtiendo el tratamiento empirista del conocimiento, que concibe que se puede acceder inmediatamente a lo real, Spinoza distingue entre el objeto y su idea ("entre el círculo real y la idea de círculo". Cfr. Parte I de este trabajo) y rechaza la posibilidad de que exista causalidad entre los atributos del alma y del cuerpo. Spinoza afirma en esta dirección "cuando los hombres dicen que tal o cual acción del cuerpo proviene del alma, por tener este imperio sobre el cuerpo, no saben lo que dicen, y no hacen sino confesar, con palabras especiosas, su ignorancia" (E, III, prop. 2, escolio).

Pero Spinoza no se limita a mostrar la identidad entre los atributos, sino que su teoria materialista, muestra que lo imaginario es algo real, y no una ilusión o la facultad de un sujeto que conoce; sino una estructura material y compleja en la que se insertan los sujetos a través de relaciones de subordinación, determinación y dominación, puesto que“... las imaginaciones no se desvanecen ante la presencia de lo verdadero en cuanto verdadero, sino porque se presentan otras imaginaciones más fuertes que excluyen la existencia presente de las cosas que imaginamos" (E, IV, prop. I, escolio).

Ahora bien, como hemos anticipado, en la lectura de Althusser, el paralelismo entre alma y cuerpo es central en el materialismo de lo imaginario de Spinoza, quien juzga una sociedad por sus rituales, prácticas e instituciones. Lo que es ilustrado, según Althusser, con el análisis que el Tratado teológico político realiza de la larga duración del estado hebreo: producida y asegurada por los ritos ceremoniales y los sacrificios. En esta explicación de la sociedad protodisciplinaria, Spinoza argumenta -según Montagque "no puede haber liberación de la mente sin la correspondiente liberación del cuerpo, ni crítica del orden social existente que no sea inmanente a los actos y prácticas de resistencia y revuelta" (Montag, 2009: 165).

Para Althusser, este análisis del Tratado teológico... constituye "la primera forma histórica de una teoría de la ideología" (UTM: 137). En la que, el poder de los 
rituales, la Thora, los sacrificios, los acatamientos...expone, por ejemplo, "que hombres que suben a la montaña siguiendo la llamada del Señor pero que, en medio del estruendo del trueno y el deslumbramiento de los relámpagos sólo escuchan algunas palabras comprensibles a medias. Vuelven a bajar entonces a la llanura para someter a sus hermanos, que entienden, ellos, el mensaje de Dios" (Ibíd.: 138). Según lo ve Althusser, en el hecho de que los profetas no entiendan la palabra de Dios- y que incluso Daniel que no llega ni siquiera a comprender las explicaciones que el pueblo le da sobre el mensaje que él ha recibido- está la "prueba prodigiosa de la violenta resistencia de toda ideología a su clarificación” (Ídem).

En este relato subyace, según Althusser que, en el "materialismo de lo imaginario" de Spinoza, hay una inmanencia de las prácticas y de las relaciones imaginarias; el mundo real, inmediato está hasta tal punto penetrado por la imaginación (primer género de conocimiento) que "es indisociable e inseparable de la misma, constituyendo la imaginación su esencia misma, el vínculo interno de todas sus determinaciones" (Ibíd.: 135). Este primer género es la materia prima de las abstracciones del segundo género, que culmina en la generalidad del tercer género de conocimiento. Este es ilustrado con el caso de la historia y el pueblo judío que representa para Althusser, el conocimiento de un objeto que es tanto singular (un individuo histórico, un pueblo determinado) como universal ${ }^{72}$.

Asimismo, este materialismo de lo imaginario de Spinoza, se encontraría también, según la lectura de Althusser, en el apéndice al libro I de la Ética donde se desarrolla la admirable crítica de la ideología religiosa ("la primera crítica al concepto ideológico de la ideología") donde el sujeto humano "dotado de deseos convertidos en fines" se proyecta en Dios como "causa originaria y final del Universo" a partir de la materialidad de la imaginación que consiste en: 1) colocar al sujeto humano en el centro y en el origen de toda percepción, de toda acción, de todo objeto y de todo sentido; 2) invertir así el orden real de las cosas, puesto que el orden real se explica por la sola determinación de las causas (mientras que la subjetividad de la imaginación explica todo por la ilusión subjetiva de los fines de su deseo y de sus expectativas).Para Althusser, Spinoza al rechazar la categoría de Sujeto por considerar que era la categoría

72 Para Spinoza, según Althusser, en la vida individual y social no hay más que singularidades (nominalismos) realmente singulares -pero universales puesto que "esas singularidades están como atravesadas y como habitadas por invariantes repetitivas o por constantes, que se pueden volver a encontrar con sus variaciones singulares en otras singularidades de la misma especie o género" (UTM: 137). 
central de la ilusión imaginaria que se articulaba con las supersticiones para "justificar la servidumbre de los hombres" (E, IV, prop. 39), "alcanzaba el corazón de la filosofía burguesa" (UTM: 136). Lo cual

A modo de repaso: de acuerdo con la lectura althusseriana, en la teoría materialista de lo imaginario (o "materialismo de lo imaginario") de Spinoza se produce una ruptura teórica con las teorías subjetivistas de la subjetividad, según las cuales la imaginación sería una facultad de un sujeto cognoscente. La teoría del conocimiento de Spinoza en cambio, postula la realidad imaginaria, es decir, el carácter imaginario de lo real. Así como muestra - al analizar las proyecciones de los hombres en Dios- que la estructura de "lo imaginario" es de centrado especular, ya que existen inversiones internas (Cfr. EA: 48- 49) en cuyo centro se encuentra la ilusión del sujeto.

Entonces bien, el propósito de todo este rodeo ha sido el de insistir en que este materialismo de lo imaginario de Spinoza, tiene vínculos profundos con la naturaleza material e imaginaria de la noción materialista de la ideología propuesta por Althusser.En la propuesta de Ideología y aparatos...Althusser señala que para mostrar los mecanismos y la estructura de la ideología (existente en toda formación social) se requiere de una tesis presuntiva acerca de la existencia material, no espiritual, de la ideología. Se trata de una tesis positiva en cuanto que refiere a la materialidad de las "ideas" u otras "representaciones", etc. de las que se compone la ideología, y que circulan en los AIE, que son "todos ellos la realización de una ideología" (IAEI: 47).

\section{La materialidad de la ideología}

...las "ideas" de un sujeto humano existen o deben existir en sus actos...

(Althusser, Ideología y aparatos...)

Althusser desarrolla su tesis de la existencia material de la ideología advirtiendo que esta no puede existir fuera del AIE a través del que se despliega puesto que: "una ideología existe siempre en un aparato, y en su práctica, o sus prácticas" (IAEI: 47. La cursiva es nuestra). Con lo cual, se descarta la posibilidad de que la ideología sea comprendida como anterior a su expresión en la materialidad de un aparato.

Pero, si la ideología no es ni la causa, ni el efecto del aparato que constituye su forma material, tampoco los aparatos preceden o dan origen a la ideología o a las ideologías, sino que son inmanentes a estas. Althusser distingue así, entre una ideología 
que "existe en" -es inmanente o consustancial con un aparato- la ideología primaria. Y la ideología producida por la práctica o las prácticas de ese aparato de Estado, las ideologías secundarias. Estas últimas son descriptas en Sobre la reproducción como producidas por la conjunción de causas complejas, en las cuales figuran el efecto de otras ideologías exteriores y otras prácticas exteriores, puesto que "no importa cuán disimulados estén los efectos distantes (pero en realidad muy cercanos) de la lucha de clases" (SR: 115). Althusser insiste así, en que la lucha de clases es constitutiva de los aparatos mismos, los que, en consecuencia, no pueden considerarse como instituciones inertes, sino que se articulan con, y son configurados en las luchas "por fuera de las cuales, no tienen existencia ni significado alguno" (Montag, 2014: 66).

Cabe señalar que, Althusser aclara al inicio de esta formulación de la tesis positiva "la ideología tiene existencia material" que la ideología a pesar de ser imaginaria (tesis negativa) no consiste en ideas falsas o ilusorias contenidas en las mentes de los individuos (menos aún en la conciencia o espíritu colectivo) que fueran la causa de que actuaran de ciertas maneras. Las creencias mentales no son las causas de las acciones corporales físicas, sino que son inmanentes, existen (no preexisten) a través de "sus" acciones.

Bajo esta concepción, todo "sujeto" dotado de una "conciencia", que cree en las "ideas" que su conciencia le inspira, "debe actuar según sus ideas" esto es, "traducir en actos de su propia práctica material sus ideas de sujeto libre" (Ídem). Y si eso no sucede, le proporciona otras ideas correspondientes. De manera que, en el marco de una filosofía materialista, la ideología existe a través de actos insertos en prácticas reguladas por rituales en los cuales se inscriben, como puede ser "una modesta misa en una pequeña iglesia, un entierro, un match de pequeñas proporciones en una sociedad deportiva, una jornada de clase en una escuela, una reunión o el mitin de un partido político, etc.” (Ibíd.: 50).

Ahora bien, así como la ideología siempre existe en un aparato, y en su (s) práctica (s) -con lo cual se descarta cualquier insinuación de anterioridad temporal y causal de la ideología con respecto a la materialidad de un aparato-, las ideas (de los sujetos individuales) existen en (sus) acciones: "Sus ideas son sus acciones materiales" (Ídem). Althusser reconoce que es gracias a Pascal -quien "trastoca (...) el orden de las cosas" al formular algo más o menos así: "Arrodíllate, mueve tus labios en oración, y creerás" (Ídem)- que se puede explicar esta obediencia real (automática) como base de las creencias subjetivas que permite descartar que las creencias mentales pudieran ser 
entendidas como anteriores a las acciones corporales de un individuo:

Diremos pues, considerando sólo un sujeto (un individuo), que la existencia de las ideas de su creencia es material, en tanto esas ideas son actos materiales insertos en prácticas materiales, reguladas por rituales materiales definidos, a su vez, por el aparato ideológico material del que proceden las ideas de ese sujeto. Naturalmente los cuatro adjetivos "materiales" inscritos en nuestra proposición deben ser afectados por modalidades diferentes, ya que la materialidad de un desplazamiento para ir a misa, del acto de arrodillarse, de un ademán para persignarse o para indicar mea culpa, de una frase, de una oración, de un acto de contrición, de una penitencia, de una mirada, de un apretón de manos, de un discurso verbal externo o de un discurso verbal "interno" (la conciencia), no son una sola y misma materialidad. Dejamos en suspenso la teoría de la diferencia de las modalidades de la materialidad.

(IAEI: 50$)^{73}$.

La fórmula pascalina, según Althusser permite mostrar que las creencias de un individuo son materiales en tanto que tienen como correlato la realización de actos materiales insertos en prácticas concretas, reguladas por rituales materiales que se definen en los AIE materiales, por el cual circulan las ideas del "sujeto", "que actúa con toda conciencia según su creencia" (IAEI: 51); es decir que, el sujeto actúa en la medida que es actuado.

Efectivamente, tomando elementos de la teoría de Pascal y "traduciéndolo a un lenguaje más marxista" principalmente el de la primacía tendencial del cuerpo respecto del alma, de la materia sobre el espíritu, Althusser propone mostrar que las acciones (materiales) de un individuo están siempre ya insertas en prácticas (materiales) que a su vez están gobernadas por los rituales (materiales) de un aparato (material). Para garantizar que los sujetos "cumplan con sus deberes", "se comporten según lo

\footnotetext{
${ }^{73}$ Para Montag (2015) existe una gran proximidad teórica de este pasaje de Ideología y aparatos...con el pasaje: "ni el cuerpo puede determinar el alma a pensar, ni el alma puede determinar al cuerpo al movimiento o al reposo" (E, III, prop. 2, esc.). Bajo el que subyace, según Montag que, la disposición del cuerpo está determinada por rituales, entre los cuales la misa católica es el ejemplo más claro. Para Montag, incluso la fe del creyente individual es material, en tanto "sus ideas son sus acciones materiales" ellas mismas "insertas en prácticas materiales gobernadas por rituales materiales" (Montag, 2015: 21). De acuerdo con esta perspectiva, Althusser al invocar diversas formas de materialidad, "es llevado por la secuencia de acciones requeridas en la participación de la misa, a referirse al discurso. La creencia del creyente, y su fe, se manifiestan y existen materialmente en "los movimientos del cuerpo al ir a misa, al arrodillarse, hacer la señal de la cruz, golpearse el pecho tres veces en el preciso momento que profiere las palabras "mea culpa, mea culpa, mea máxima culpa"' (Ídem). Retomaremos la dimensión discursiva en el análisis de las Tres notas sobre la teoría de los discursos.
} 
requerido", y "asuman libremente" sin necesidad de violencia represiva, aquello que se ha previsto para ellos (de acuerdo con la posición que ocupan en la trama de relaciones sociales en las que están insertos) es fundamental la lógica de repetición automática, por la que daremos un rodeo.

\section{El "automatismo de la repetición"}

Puesto que esta repetición es repetición simbólica, se muestra en ella que el orden del símbolo no puede ya concebirse como constituido por

el hombre sino como constituyéndolo (Lacan, El seminario sobre 'La carta robada')

En El seminario sobre "La carta robada" Lacan sostiene que el automatismo de la repetición [Wiederholungszwang] toma su principio en la insistencia de la cadena significante. En este sentido, las impregnaciones imaginarias [Prägung] "dan a la cadena simbólica su andadura" (Lacan, 2012: 23).

Sin embargo, Lacan insiste también en que es la ley de esta cadena lo que rige los efectos psicoanalíticos determinantes para el sujeto como: la preclusión/ forclusión [Verwerfung]; la represión [Verdrängung]; la denegación [Verneinung]. Esos efectos, según Lacan, siguen "tal fielmente el desplazamiento [Entstellung] del significante que los factores imaginarios, a pesar de su inercia, sólo hacen en ellos el papel de sombras y de reflejos" (Ídem). En este sentido, lo que quiere destacar Lacan es la determinación fundamental que el sujeto recibe del recorrido de un significante, y que lo constituye en cuanto tal, como señalara Freud. Para enfatizar esto, Lacan analiza el cuento de Poe que Baudelaire tradujo con el título La lettre volée ("La carta robada") ${ }^{74}$, el que "tiene la ventaja de manifestar la necesidad simbólica de manera tanto más pura" (Ibíd.: 24). La narración de la historia es presentada en dos escenas: la primitiva, y la repetición de esta.

La primera escena, tiene su desarrollo en el tocador de la Reina, quien, estando sola allí, recibe una carta cuyo contenido pondría en juego su honor y su seguridad. Razón por la cual, esta aprovecha un descuido del Rey para dejarla sobre la mesa "vuelta con el sobrescrito hacia arriba" (Ibíd.: 25). Sin embargo, el Ministro se da cuenta de ello, y roba la carta a la Reina, la que, a su vez, "sabe que es él quien la posee

\footnotetext{
${ }^{74}$ El título original es The purloined letter que Lacan traduce como "poner a la izquierda".
} 
ahora, y no inocentemente" (Ídem). Mientras que, la segunda escena ocurre en el despacho del Ministro a quien Dupin, el jefe de la policía, aprovecha un descuido del primero para robarle la carta sustituyéndole su simulacro, cuyo contenido son las siguientes palabras (trazadas para que las reconozca como de la mano de Dupin): “...un designio tan funesto, si no es digno de Atreo, es digno de Tieste” (Ibíd.: 26).

Estas escenas, señala Lacan, se articulan en un complejo intersubjetivo en el que primeramente hay una mirada que no ve nada: la del Rey y de la policía. En el segundo momento, "una mirada que ve que la primera no ve nada y se engaña creyendo ver cubierto por ello lo que esconde: es la Reina, después es el Ministro" (Ibíd.: 27). El tercero, ve que esas dos miradas dejan lo que se esconde a plena vista para que esté disponible y quien quiera pueda apoderarse de ello: es el Ministro, y es, Dupin.

Ahora bien, lo que interesa de este relato es el módulo intersubjetivo de la acción que se repite, y del que, según Lacan, falta reconocer en él un automatismo de la repetición, que es inconsciente. Partiendo de la idea de que el inconsciente es el discurso del Otro, Lacan señala que lo que interesa al respecto es,

la manera en que los sujetos se relevan en su desplazamiento en el transcurso de la repetición intersubjetiva (...) este desplazamiento está determinado por el lugar que viene a ocupar el puro significante que es la carta robada, es su trío. Y es esto lo que para nosotros lo confirmará como automatismo de la repetición.

(Lacan, 2012: 28)

Esta repetición se dirige a buscar el significado original pero nunca lo alcanza puesto que, las sucesivas suplantaciones borran por completo la idea de significado como algo originario, y en su lugar el significante es lo único a lo que el sujeto puede remitirse. Sin embargo, la mirada lacaniana detecta que la historia nos hace dejar de pensar tanto en el remitente como en el contenido de la carta, para que adquiera centralidad el modo en que el significado es construido por el significante. En este sentido, Lacan señala que: "cualquiera que sea el destino escogido por la Reina para la carta, esa carta es el símbolo de un pacto, y que incluso si su destinataria no asume ese pacto, la existencia de la carta la sitúa en una cadena simbólica extraña a la que constituye su fe" (Ibíd.: 39).Yannis Stavrakakis (2007) afirma que en la teoría lacaniana la significación es producida a través de las relaciones entre los significantes, mediante la formación de cadenas lingüísticas, que remiten a otras cadenas. El término 
que usa Lacan es "cadena significante" justamente porque "da una idea aproximada: anillos cuyo collar se sella en el anillo de otro collar hecho de anillos" (EE: 153, citado por Stavrakakis, 2007: 94).

Ahora bien, luego de dar un rodeo por las vicisitudes de La carta robada, Lacan señala que el verdadero tema o protagonista del relato es la singularidad de "la carta", cuya desviación le es propia y le otorga su incidencia de significante. De esta manera, lo que se obtiene es la idea de que el significante se mantiene en un desplazamiento con un funcionamiento alternante, como el de los carteles luminosos, que lo obliga a abandonar su lugar "a riesgo de regresar circularmente" (Ibíd.: 40). Esto es lo que ocurre en el automatismo de la repetición. Pero, además, "el desplazamiento del significante determina a los sujetos en sus actos, en su destino, en sus rechazos, en sus cegueras, en sus éxitos y en su suerte, a despecho de sus dotes innatos y de su logro social, sin consideración del carácter o el sexo" (Lacan, 2012: 40).

Para Lacan, este mecanismo del automatismo de repetición nos enseña que el sujeto se "moldea" al ingresar en la cadena significante; pero esto no ocurre sólo con el sujeto singular sino con los sujetos tomados en su intersubjetividad, "los que toman la fila, los que moldean su ser" (Ibíd.: 55). Pero, además, este mecanismo de repetición no sería ejecutado por un agente humano identificado consciente, sino que la repetición es simbólica, lo que manifiesta que el orden simbólico constituye a los sujetos. Freud ejemplifica según Lacan, el modo de operar de la repetición con el juego del niño de hacer desaparecer un objeto, luego hacerlo aparecer, obliterarlo nuevamente y así... “ese juego, manifiesta en sus rasgos radicales la determinación que el animal humano recibe del orden simbólico" (ídem). Lo que Lacan analiza de este ejemplo es que el ingreso al orden simbólico ocurre en el punto cero del deseo, donde el objeto humano cae bajo el efecto de la captura que "anulando su propiedad natural, lo somete desde ese momento a las condiciones del símbolo" (Ídem).

La conclusión de Lacan respecto a la carta robada es que "la subjetividad en su origen no es de ningún modo incumbencia de lo real, sino de una sintaxis que engendra en ella la marca significante" (Ibíd.: 59). Con lo cual, a través del recurso a la ficción del relato, Lacan argumenta que hay un determinismo psíquico del que no somos fundantes sino sólo agentes, lo que manifiesta la profunda articulación entre la estructura de la ideología y la estructura del inconsciente.

Ahora bien, el énfasis colocado en la ideología como "profundamente inconsciente" ya se encuentra en la recepción del pensamiento de Lacan que Althusser 
manifiesta en Marxismo y humanismo, donde la ideología tiene una función práctica y social. En ese texto de 1963 Althusser termina de profundizar el corte con la concepción idealista de la ideología al comprenderla como objetos "culturales percibidosaceptados- soportados" que actúan funcionalmente sobre los hombres "mediante un proceso que se les escapa", que no eligen y que no fundan; reforzando su apuesta "de combatir al Sujeto bajo todos sus disfraces"75 (Aguilar Rivero, 1984: 55).

Althusser rechaza así, como hemos señalado en la primera parte, la problemática idealista de la ideología en la que esta es colocada dentro de la dimensión de la conciencia puesto que la ideología "es profundamente inconsciente": son imágenes, a veces, conceptos, pero, sobre todo, son estructuras que se imponen a los hombres y ellos la viven, de manera inconsciente, como su "mundo mismo" (RTM: 193). La manera en que los hombres "viven" su vida y se relacionan con su mundo, involucra una relación imaginaria, que enviste a la relación real, y que expresa más una voluntad (conservadora, conformista, reformista o revolucionaria), una esperanza o una nostalgia que la descripción de una realidad" (Ibíd.: 194).

La cita anterior manifiesta, según nuestra perspectiva, el estatuto central que lo imaginario tiene en las relaciones vividas, como constitutivas de la ideología. Esta relación entre lo que se vive de determinada manera: lo vivido, y lo imaginario permite comprender la importancia que tiene el componente afectivo (voluntad, nostalgia, esperanzas, creencias, valores morales, deseos, miedos) en las relaciones que mantenemos con nosotros mismos y con nuestro entorno social. Por eso es que, para Balibar, por ejemplo, las ideologías "son ante todo las diferentes formas históricas en que las condiciones inconscientes pueden ser elaboradas para permitir a individuos y a grupos imaginar su propia práctica” (Balibar, 2004: 90).

Entonces bien, en Marxismo y humanismo, la ideología es una instancia social fundamental, que, al articularse con la dimensión imaginaria e inconsciente, tiene potencialidad para "moldear" a los hombres, para que respondan a las exigencias de la estructura social. Sin embargo, Althusser destaca también que "la ideología tiene un papel activo sobre la clase dominante misma y contribuye a modelarla" (RTM: 195). Este énfasis en la función práctica y social de la ideología, así como su naturaleza

\footnotetext{
75 Profundizando el rechazo transversal de la categoría idealista de "sujeto" que sostiene las ilusiones y "los cuentos" que impiden reconocer "la cartografía básica de un mundo articulado sobre el poder de clase, porque dibujan, por el contrario, un horizonte plano en el que permanece 'sujeto' cualquier deseo de socialidad otra" (MDL: 12).
} 
inconsciente e imaginaria, es reforzada unos años más tarde en el ensayo de 1970, donde la realización de prácticas por el efecto de la ideología es posible por el mecanismo de la interpelación ideológica puesto que "la ideología interpela a los individuos y los constituye en sujetos" (tesis III) ${ }^{76}$.

Althusser fue llegando a la formulación de la tesis central de Ideología... la de la interpelación ideológica a través de una tesis conjunta: "no hay práctica a través de y bajo una ideología; no hay ideología sino a través del sujeto y para los sujetos" (IAEI: 51). Esta tesis manifiesta una doble relación de inmanencia: a) entre sujeto e ideología que revela a su vez, la necesariedad de que los individuos se constituyan en sujetos, es decir que se identifiquen con las prácticas que deben realizar de acuerdo con el discurso que los interpela para ocupar los lugares que se les ha determinado previamente; b) entre las prácticas materiales y la ideología.

Pêcheux (2016) señala que en la primera parte de la tesis ("no hay práctica...") el artículo indefinido ("una) sugiere pensar en la "pluralidad diferenciada de la instancia ideológica bajo la forma de una combinación (todo complejo con dominante) de elementos", cada uno de los cuales es una formación ideológica: una ideología. Mientras que, en la segunda parte de la tesis conjunta ("no hay ideología...") la aparición del término "sujeto" se caracteriza por el hecho de que este término "no es ni sujeto ni objeto, sino atributo del objeto" y el término "ideología" refiere a "ideología en singular", en el sentido de "toda ideología" (Pêcheux, 2016: 133-134).

Para Althusser "sólo existe ideología para los sujetos concretos y esta destinación de la ideología es posible por el sujeto: es decir por la categoría de sujeto y su funcionamiento" (IAIE: 52). De modo que la función- sujeto tendrá en el marco de la teoría de la ideología propuesta por Althusser, un estatuto central (y en efecto, la comanda) para lograr la reproducción de la ideología de las clases dominantes ${ }^{77}$. Lo que refuerza la posición althusseriana ${ }^{78}$ de rechazo a la idea de un "sujeto constituyente".

Dado que, en el marco de la teoría materialista de la ideología de Althusser, esta

\footnotetext{
76 Desde una teoría materialista de los discursos, Pêcheux propondrá que los constituye en "sujetoshablantes" (sujetos de su discurso) por las formaciones discursivas que representan. Pero, no equiparando mecánicamente ideología a discurso, sino poniendo en juego una "intrincación" deformaciones discursivas en las formaciones ideológicas "intrincación cuyo principio residiría precisamente en la interpelación" (Pêcheux, 2016: 143).

77 Para De Ipola (2007) en la obra de Althusser la categoría de "sujeto" carecería de toda pertinencia teórica ya que "no habría sujeto más que como fantasma ilusorio de los individuos" (p. 138).

78 Para Gabriela Manini (2015) sostener esta tensión implica reconocer cómo opera la intervención de Althusser sobre la idea de sujeto-hombre como fundamento, y su crítica de las tendencias metafísicas, antropológicas, así como de las filosofías de la historia, que maquillaron los marxismos del siglo XX.
} 
tiene por función central constituir a los individuos en sujetos, proponemos examinar el complejo mecanismo mediante el que se produce la subjetivación (cuyo reverso es para Althusser, la sujeción), el de la interpelación ideológica. 


\section{Capítulo V. La interpelación ideológica en Ideología y aparatos...}

Sería, pues, bueno que se obedezca a las leyes y a las costumbres porque son leyes...Pero el pueblo no es susceptible de esta doctrina; y así como cree que la verdad puede encontrarse y que se halla en las leyes y en las costumbres, las cree y considera su antigüedad como una prueba de su verdad (y no ve su sola autoridad sin verdad).

(Pascal, Pensamientos)

Dado que, en el marco de la teoría materialista de la ideología de Althusser, esta tiene por función central constituir a los individuos en sujetos, proponemos examinar el complejo mecanismo de subjetivación/ sujeción a través de la práctica de la interpelación ideológica, como objetivo central de este capítulo. Para ello, examinaremos su lógica de reconocimiento/ desconocimiento y su profunda articulación con la estructura del inconsciente.

Asimismo, mostraremos cuestiones problemáticas que la práctica de la interpelación ideológica presenta en el marco de Ideología y aparatos... y que ha dado lugar a críticas vinculadas a interpretaciones reproductivistas y funcionalistas. 


\section{El mecanismo de subjetivación/ sujeción}

Una sujeción real nace mecánicamente de una relación ficticia.

(Foucault, Vigilar y castigar)

De acuerdo con la operación de la interpelación ideológica ${ }^{79}$-una alegoría o escena (de tipo teatral)- "solo existe ideología para los sujetos concretos y esto es posible por el funcionamiento de la categoría de sujeto" (es decir, la constitución de los individuos concretos en sujetos). Con lo cual se manifiesta que existe una relación de inmanencia entre la ideología y las prácticas, y entre la ideología y los sujetos. La escena de la interpelación ideológica es presentada en Ideología y aparatos... de la siguiente manera:

Tanto para ustedes como para mí, la categoría de sujeto es una "evidencia" primera: está claro que ustedes y yo somos sujetos (libres, morales, etc.). Como todas las evidencias, incluso aquellas por las cuales una palabra "designa una cosa" o "posee una significación" (incluyendo por lo tanto las evidencias de la transparencia del lenguaje) esta "evidencia" de que ustedes y yo somos sujetos- y el que esto no constituya un problema- es un efecto ideológico, el efecto ideológico elemental.

En efecto, es propio de la ideología imponer (sin parecerlo, dado que son "evidencias") las evidencias como evidencias que no podemos dejar de reconocer, y ante las cuales tenemos la inevitable y natural reacción de exclamar (en voz alta o en el "silencio de la conciencia”): “¡Es evidente! ¡Eso es! ¡Es muy cierto!

(IAEI: 53)

Althusser recurre a nuestro "sentido común", y a la naturalidad con la que vivimos en la ideología -en tanto animales ideológicos (en sentido spinoziano)-al presentar la interpelación como uno de los rituales más cotidianos, frente al que respondemos satisfactoriamente, mediante el reconocimiento ideológico; que puede ser ilustrado con lo que ocurre por ejemplo cuando reconocemos a alguien en la calle y se

\footnotetext{
${ }^{79}$ Montag (2014) indaga en la etimología del verbo interpelar [interpeller] que es usualmente entendido por los lectores angloparlantes sobre la base de la traducción "to hail someone": llamar a alguien o quizás abordar a alguien (como Dios, para Althusser, llama a Moisés). Pero esta traducción según Montag, no logra captar el énfasis que Althusser coloca sobre uno de los aspectos que el término elegido tiene en el francés moderno -y que tiene un sentido particular en el periodo inmediatamente posterior a la revuelta de mayo de 1968- donde "interpelar" se refiere a la acción policial de detener a un individuo ("stop" or "detain" an "individual") (p. 63). Esta acepción toma la forma de un mandato, que se diluiría en Ideología y aparatos..., pero que tiene centralidad en las Tres Notas...
} 
lo hacemos saber estrechándole la mano (uno de los rituales del reconocimiento ideológico más común).

Este reconocimiento ideológico manifiesta una primera evidencia: la de ser sujetos (“'ies evidente, soy yo!”), que Althusser explica de la siguiente manera: "Usted y yo somos siempre ya sujetos, que como tales practicamos sin interrupción los rituales del reconocimiento ideológico que nos garantizan que somos realmente sujetos concretos, individuales, inconfundibles e irremplazables" (Ibíd.: 54). Atendiendo a esta evidencia primera, Pêcheux desarrolla la correspondencia con la evidencia del significado "esa palabra designa X cosa". De acuerdo con el análisis de Pêcheux, la distinción entre individuo (pre-ideológico) y sujeto (efecto de la interpelación) es lo que le permite a Althusser evitar presuponer la existencia del sujeto sobre el que se efectuaría la operación de interpelación. De allí que se afirme "la ideología interpela a los individuos como sujetos" no se dice: "El sujeto es interpelado por la Ideología"” (Pêcheux, 2016: 138). Lo que designa, según Pêcheux, este desfasaje entre "individuo/sujeto" es que "un no- sujeto es interpelado- constituido en sujeto por la Ideología" (Ídem). La interpelación tendría así, desde su perspectiva crítica, un efecto retroactivo que hace que todo individuo sea siempre ya sujeto.

Entonces bien, frente a la evidencia de que somos inmediatamente sujetos -y de que es a nosotros a quien se dirige el llamado de la interpelación ideológicarespondemos, mediante la operación del reconocimiento ideológico, como reacción a esta evidencia primera. Este reconocimiento, se produce según Althusser en el momento exacto en el que el individuo interpelado gira. "Por esa simple conversión física de 180 grados, se convierte en sujeto porque reconoció que la interpelación se dirigía precisamente a él” (Ibíd.: 55):

Sugerimos entonces que la ideología "actúa" o "funciona" de tal modo que "recluta" sujetos entre los individuos (los recluta a todos), o "transforma" a los individuos en sujetos (los transforma a todos) por medio de esta operación muy precisa que llamamos interpelación y que se puede representar con la más trivial y corriente interpelación policial (o no) "eh, usted, oiga".

(IAEI: 55)

La ideología se dirige a los individuos como sujetos, quienes al reconocer que es precisamente a ellos que se dirige el llamado de la interpelación ideológica, se 
convierten en ese mismo acto, en "sujetos" (interpelados). Y eso ocurre, según Althusser, casi sin margen de error -en el 90\% de los casos dice Althusser- puesto que "las telecomunicaciones prácticas de la interpelación siempre alcanzan al hombre buscado: se trate de un llamado verbal o un toque de silbato" (Ídem.). En la mayoría de los casos, el interpelado responde ante este llamado, "creyendo-suponiendo-sabiendo" que era precisamente a él que se dirigía el llamado.

Althusser argumenta que este "pequeño teatro teórico" 80 es presentado bajo una secuencia temporal, como provisional explicativo; pero no existe tal secuencia, sino que "la existencia de la ideología y la interpelación de los individuos como sujetos son una sola y misma cosa" (Ibíd.: 56). Por otra parte, frente a lo que parecería suceder fuera de la ideología, en la calle, por ejemplo, en realidad ocurre en la ideología misma, ya que no hay un afuera/ externo a esta. La creencia de no estar inmerso en la ideología es uno de los efectos ideológicos por excelencia.

Ahora bien, la tesis de que "la ideología no tiene afuera" (para ella, es decir, para el sujeto) es planteada por Althusser, según Pêcheux, en una proximidad paradojal con una segunda fórmula que la invierte: "la ideología no es más que afuera" (para la ciencia). Razón por la cual ya no puede plantearse una pregunta que para Pêcheux constituye una especie de "puente de asnos”: “cómo por qué, desde qué punto de vista, etc. puede decirse que la ideología no es más que afuera?" (Pêcheux, 2016: 157. La cursiva es nuestra). Frente a este problema, que nos coloca muy próximos a un realismo metafísico y a un empirismo, Pêcheux señala -siguiendo el método marxista del materialismo dialéctico- que el punto de partida no es el hombre, sino que "el verdadero punto de partida a partir del cual podemos comprender que 'la ideología no es más que afuera' para la ciencia es (...) el de las condiciones ideológicas de reproducción/ transformación de las relaciones de producción" (Ibíd.: 158-159).

En efecto, para Pêcheux, no debe perderse de vista la referencia materialista a las relaciones de producción y al modo de producción que las implica. En este sentido, es necesario reconocer/ recordar que los conocimientos científicos, por ejemplo, son

\footnotetext{
${ }^{80}$ Montag detecta que la expresión "la ideología interpela" se lee a menudo como un drama (trágico) de reconocimiento que se asemeja a la dialéctica de la conciencia y la autoconciencia en la Fenomenología del Espíritu: el sujeto existe en sí y por sí solo en tanto que es reconocido (o llamado). De este modo, la interpelación del sujeto sería ella misma un proceso subjetivo, desplegándose enteramente dentro del ámbito de la conciencia o la intersubjetividad. Sería así ideológico en el antiguo sentido, una idea o representación falsa contrapuesta a la realidad (Montag, 2009: 168). Pero, este "teatro teórico" de la interpelación "es concebido como una crítica ilustrada del teatro de la conciencia, en el sentido que lo enuncia Pêcheux (2016: 138).
} 
producidos por los hombres en sociedad. Dado que, la actividad humana social e histórica, presupone, para Pêcheux, "la existencia de la sociedad y de la historia fuera de las relaciones de producción y de la lucha de clases" (Ibíd.: 163).

Entonces bien, Althusser insiste en que, la ideología no es otra cosa que un afuera, con carácter imaginario y con una estructura doblemente especular ${ }^{81}$ que ordena la existencia social de los sujetos. Pero este ordenamiento no es arbitrario, sino que "cada clase se reconoce en una ideología particular, la que es capaz de unificarla y de orientar su lucha de clases" (IF: 156). Así como la clase feudal se reconoce en la ideología religiosa, la burguesía en la ideología jurídica, y la clase obrera en la ideología proletaria (lo que demuestra que la ideología puede ser ideológica en su forma, pero científica en cuanto a su contenido); para Althusser, ninguna ideología en el mundo "ni siquiera si se trata de la religión, es puramente arbitraria. Siempre es indicadora de cuestiones o problemas reales, aunque estos aparezcan revestidos de una forma de desconocimiento, y por eso, necesariamente ilusoria" (Ibíd.: 157).

La ilusión imaginaria de la ideología consiste entonces, como reconoce Teresa de Lauretis en "un sistema infalible cuyo efecto es borrar sus huellas completamente, de modo que, cualquiera que esté en la ideología, capturado/a en sus redes, se cree a sí mismo/a fuera y libre de ella" (Lauretis, 1996: 26). Sin embargo, como exploraremos en la III parte de este trabajo, a diferencia de Althusser para quien -según de Lauretis- el afuera de la ideología se encuentra en la ciencia o el conocimiento científico "este no es el caso del feminismo y de lo que propongo llamar, el sujeto del feminismo" (Ibíd.: 16), un sujeto "no tan definido (...) que está al mismo tiempo, dentro y fuera de la ideología de género, y es consciente de estarlo" (Ibíd.: 26). Por ello es que para Lauretis, el feminismo no pueda catalogarse, como una ciencia, como un discurso o como una realidad fuera de la ideología, o afuera del género como una instancia de la ideología" (Ibíd.: 17).

\section{Reconocimiento ideológico y estructura de la ideología}

Si imaginamos que otro ama o desea (...) lo que nosotros amamos o deseamos (...) por eso mismo amaremos, desearemos (...) con más constancia. (Spinoza, Ética)

\footnotetext{
${ }^{81}$ En las Tres notas sobre la teoría de los discursos, señalará que la estructura de la ideología, "produce el efecto inconsciente en los sujetos" ...lo exploraremos más adelante.
} 
Todavía sigue en pie responder ¿cómo sabe fehacientemente el interpelado que era precisamente a él que se dirigía la interpelación ideológica? Althusser escoge una figura retórica, la de la ideología cristiana ${ }^{82}$ - un ejemplo extensivo a otras formas de ideología- para ilustrar cómo los "actores" de la puesta en escena de la interpelación y sus roles específicos son reflejados en la estructura misma de la ideología, "que es siempre la misma" ${ }^{" 83}$ (IAEI: 58).Esta figura retórica se manifiesta, según Althusser, no sólo a través de su discurso, sino también a través de sus prácticas, rituales, ceremonias, y procede más o menos de esta manera: "Yo me dirijo a ti, individuo humano llamado Pedro, para decirte que Dios existe, y que tú le debes rendir cuentas (...) es Dios quien se dirige a ti por medio de mi voz (...) Dice: he aquí quien eres tú: ¡Tú eres Pedro! (...)” (Ibíd.: 58-59).

La ideología religiosa se dirige precisamente a los individuos para transformarlos en sujetos, libres de "obedecer o desobedecer" al llamado, es decir, a las órdenes de Dios que los llama por su nombre, reconociendo que "ellos son siempre ya interpelados como sujetos dotados de una identidad personal (...)" (Ibíd.: 59). Aludiendo al Cristo de Pascal, Althusser señala que la interpelación ocurre de tal modo que cuando este (Dios) dice: "por ti he derramado cada gota de sangre", el interpelado responde: "si soy yo" (Ídem). La interpelación a los individuos supone la existencia de Otro sujeto, Único y Central en nombre del cual la ideología religiosa interpela a los individuos como sujetos: "Dios se definió a sí mismo como el Sujeto, aquel que es por síypara sí ("Yo soy Aquel que soy") y Aquel que interpela a su sujeto, el individuo que le está sometido por su interpelación misma, a saber, el individuo denominado Moisés. Moisés interpelado, reconoce que era precisamente él quien era llamado por Dios. Reconoce que es sujeto, sujeto de Dios, sujeto sometido a Dios, sujeto por el Sujeto y sometido al Sujeto.

\footnotetext{
${ }^{82}$ Como señala Mariflor Aguilar Rivero (2019: 41- 42) el origen remoto de un discurso del "llamado" o la interpelación, es teológico- bíblico. Lo que se ilustra en Ideología y aparatos...con la llamada de Yahvé (Dios) a Moisés; ante la cual, este último responde: " ¡Yo soy Moisés, tu servidor, habla y yo te escucharé!".

${ }^{83}$ Montag (2014) señala que tanto en Sobre la reproducción como en Ideología y aparatos... Althusser comienza con una justificación de la propia noción de "ejemplo" que, como ilustración de una generalidad, podría parecer que introduce una lógica emanativa que contradice su constante insistencia en la inmanencia y la singularidad.
} 
Siguiendo por esta vía. Dios: (el Sujeto) se desdobla y envía a su Hijo a la tierra, ya que necesita convertirse en sujeto "como para demostrar empíricamente" a los otros sujetos que, "si son sujetos sometidos al Sujeto, es únicamente para regresar al Sujeto" (Ibíd.: 61). Este redoblamiento del Sujeto en sujetos, y del Sujeto mismo en sujetoSujeto revela el carácter centrado- especular de la estructura de la ideología que interpela a los individuos como sujetos en nombre de un Sujeto Único y Absoluto. Y es justamente este redoblamiento especular -constitutivo de la ideología- el que asegura su funcionamiento. Puesto que,

la estructura de toda ideología, al interpelar a los individuos como sujetos en nombre de un Sujeto Único y Absoluto es especular. Es decir, en forma de espejo, y doblemente especular (...). Lo cual significa que toda ideología está centrada, que el Sujeto Absoluto ocupa el lugar único del Centro e interpela a su alrededor a la infinidad de los individuos como sujetos en una doble relación especular tal que somete a los sujetos al Sujeto, al mismo tiempo que les da en el Sujeto -en que todo sujeto puede contemplar su propia imagen (presente y futura)la garantía de que se trata precisamente de ellos y de Él y de que, al quedar todo en Familia, "Dios reconocerá en ella a los suyos", es decir que aquellos que hayan reconocido a Dios y se hayan reconocido en El serán salvados.

(IAEI: 61)

La estructura especular redoblada de la ideología asegurada a la vez quedaría de la siguiente manera:

1) la interpelación de los individuos en tanto que sujetos;

2) el sometimiento (sujeción) del sujeto al Sujeto;

3) el mutuo reconocimiento entre sujetos y el Sujeto, y entre los sujetos entre sí;

4) y la garantía absoluta de que todo está bien como está y de que a condición de que los sujetos reconozcan lo que son y actúen en consecuencia todo irá bien.

Para Althusser "cogidos dentro de este cuádruple sistema de interpelación en tanto que sujetos de sometimiento (sujeción) al Sujeto, de reconocimiento universal y de garantía absoluta, los sujetos "marchan solos" en la mayoría de los casos. A excepción de los malos sujetos "que provocan la intervención ocasional de tal o cual destacamento del aparato represivo del Estado" (Ibíd.: 62).

De acuerdo con la perspectiva de Montag (2014) en Sobre la reproducción, la estructura formal asegura tres operaciones simultáneas: 1) la interpelación de los individuos como sujetos; 2) el reconocimiento mutuo entre los sujetos y el Sujeto; 3) la 
garantía absoluta de que todo realmente es lo que es: que Dios es Dios, que Pedro es Pedro y que, si la sujeción de los sujetos al Sujeto es realmente respetada, todo marchará bien para ellos, serán recompensados: “¡serás salvado tú, Pedro! ¡y formarás parte del Cuerpo Glorioso de Cristo!” (SR: 233).

Mientras que en Ideología y aparatos... la estructura de la ideología no es ya triple, sino cuádruple. Ya que entre los puntos 1 y 2, es decir, entre la interpelación de los individuos como sujetos, por un lado, y las tres formas de reconocimiento (de los sujetos con el Sujeto, de los sujetos entre sí, y de auto-reconocimiento de cada sujeto), Althusser inserta la operación de sujeción (assujettisement) del sujeto al Sujeto. Para Montag, Althusser agrega con ello, "una explicación del vínculo entre lo que podríamos llamar subjetivación y sujeción" (Montag, 2014: 68).

Ahora bien, ¿la interpelación implica per se la identificación? ¿qué es lo que garantiza que los sujetos "marchen solos"? Para Althusser eso "resulta un misterio" que derivaría de la ambigüedad del término "sujeto" que puede significar tanto una "subjetividad libre, un centro de iniciativas, autor y responsable de sus actos" (IAEI. 63); como "un ser sojuzgado, sometido a una autoridad superior, por lo tanto, despojado de toda libertad, salvo la de aceptar libremente su sumisión" (Ídem.). Retomaremos esta cuestión en el próximo capítulo, antes bien, algunas palabras más sobre la función central de la ideología.

El efecto de la interpelación ideológica es la constitución del sujeto o la construcción de su identidad -que tiene lugar cuando el sujeto se reconoce como aquél a quien el llamado ha sido dirigido- de modo que la conformación de la subjetividad tiene que ver en primera instancia con procesos de reconocimiento y de identificación. Este proceso se manifiesta en la penúltima frase de Ideología...donde Althusser plantea una pregunta fundamental: “¿qué implica realmente ese mecanismo del reconocimiento especular del Sujeto, de los individuos interpelados como sujetos y de la garantía dada por el Sujeto a los sujetos si aceptan libremente su sometimiento a las órdenes del Sujeto?" (Ibíd.: 63).

Pero este reconocimiento de ser sujetos, recubre un momento de desconocimiento y de ilusión de unidad que implica que demos un rodeo por la teoría del "Estadio del Espejo", texto en el que Lacan realiza por primera vez, un análisis exhaustivo de la identificación. 


\section{El desconocimiento y la ilusión de unidad/ totalidad}

... el sujeto humano deseante se constituye en torno a un centro que es el otro en tanto le brinda su unidad...

(Lacan, seminario III)

Fantasía es precisamente el modo en que se disimula la figura antagónica. (Zizek, El sublime objeto de la ideología)

"El estadio del espejo como formador de la función del yo (je) tal como se nos revela en la experiencia psicoanalítica" ([1949] 2012) es la conferencia que Jacques Lacan pronuncia en 1949 en el Congreso Internacional de Psicoanálisis de Zúrich en la que analiza la función del yo "en la experiencia que de él nos da el psicoanálisis (...) y que se opone a toda filosofía derivada directamente del cogito" (EE: 99). En realidad, como señala Yannis Stavrakakis (2007) se trata de la primera contribución significativa de Lacan a la teoría analítica presentada en el Decimocuarto Congreso Psicoanalítico Internacional, que se llevó a cabo en Marienband en 1936, pero fue reescrito en 1949.

Y es también la primera contribución detallada que Lacan realiza del concepto de identificación, proceso que aparece descrito a través del "estadio del espejo". Este estadio ocurre -según Lacan- entre los 6 y 18 meses de vida del infans en el que este reconoce su imagen en el espejo; reconocimiento que comparte con el chimpancé pero que no se agota allí, sino que "rebota en seguida en el niño en una serie de gestos en los que experimenta lúdicamente la relación de los movimientos asumidos de la imagen con su medio ambiente reflejado" (Ídem).

Para Lacan, el hecho de que su imagen especular sea asumida jubilosamente ante la posibilidad de integrar su fragmentación en una totalidad y unidad imaginariasmanifiesta la matriz simbólica en la que el yo (je) "se precipita en una forma primordial, antes de objetivarse en la dialéctica de la identificación con el otro, y antes de que el lenguaje le restituya en lo universal, su función de sujeto" (Ibíd.: 100). Ya que después, este sentimiento de gozo ante la unidad imaginaria "es reemplazada por un resurgimiento de la distancia entre esta nueva unidad y el carácter fragmentario, no coordinado y carente de la experiencia vivida del niño de su cuerpo real" (Stavrakakis, 2007: 39). Puesto que, además, la imagen en el espejo, es diferente al tamaño real del niño, de manera que se le opone como algo extraño, que "prefigura su destinación alienante" (EE: 101).

Entonces bien, Lacan afirma que hay que comprender el estadio del espejo como 
una identificación (proceso de identificación) primaria en la que se produce el ego, puesto que se trata de "la transformación producida en el sujeto cuando asume una imagen, cuya predestinación a este efecto de base está suficientemente indicada por el uso, en la teoría, del término imago" (Ibíd.: 100. Las cursivas son del original). Para los imagos, la imagen especular parece ser el umbral del mundo visible, sea que se trate de sus rasgos individuales, de sus discapacidades o de sus proyecciones objetales.

Esa forma, según Lacan, debe designarse como yo- $i d e a l^{84}$, que sitúa la instancia del yo, aun antes de su determinación social, en una línea de ficción, irreductible para siempre por el individuo solo. La forma total y plena del cuerpo "gracias a la cual el sujeto se adelanta en un espejismo a la maduración de su poder, no le es dada sino como Gestalt" (Ídem); es decir, en una exterioridad que "está preñada todavía de las correspondencias que unen al yo (je) a la estatua en que el hombre se proyecta como a los fantasmas que lo dominan, al autómata, en fin, en el cual, en una relación ambigua, tiende a redondearse el mundo de su fabricación” (Ibíd. 101).

Lacan critica la "filosofía contemporánea del ser y la nada" que -al presuponer la conciencia que se encuentra inscripta en sus premisas- "encadena a los desconocimientos constitutivos del yo la ilusión de autonomía en que se confia”" (Ibíd.: 104). A esta filosofía se opone la experiencia psicoanalítica, según Lacan, ya que obstaculiza "concebir el yo como centrado sobre el sistema-percepción- conciencia (...) para indicarnos que partamos de la función de desconocimiento que lo caracteriza en todas las estructuras" (Ibíd.: 105).Frente a este tratamiento idealista de la conciencia, en el análisis del estadio del espejo, el reconocimiento del sujeto en la imagen especular (una imagen de unidad) es comprendido como un desconocimiento del verdadero yo: un "yo escindido", "fragmentado" 85 . Lo que desconoce fundamentalmente el sujeto son los determinantes simbólicos de su subjetividad, la determinación simbólica de su ser. Por ello es que "confrontado con su imagen en el espejo, el niño se encuentra frente a un problema de conocimiento y de reconocimiento de la realidad" (Ogilvie, 2010: 97).

En esta línea, lo que ocurre a ese infans es que encuentra en el espejo la manera

\footnotetext{
${ }^{84}$ En nota del traductor se aclara que "Lacan se atendrá a la traducción de Idealich por moi- ideal, conceptualizándolo de acuerdo con su bipartición: moi-yo, como construcción imaginaria; y je- yo como posición simbólica del sujeto" (EE: 100). Es a partir de esta bipartición que Zizek distingue entre la identificación imaginaria y la identificación simbólica (SOI: 147).

85 "El ego, la imagen en la que nos reconocemos a nosotros mismos, es siempre un alter ego extraño: somos "una colección incoherente de deseos - este es el verdadero sentido de la expresión cuerpo fragmentado (...) y la primera síntesis del ego es esencialmente alter ego, está alienada" (Stavrakakis, 2007: 40).
} 
de identificarse con la imagen del semejante, "en una identificación emancipadora y enajenante que incluye la presencia de lo simbólico, puesto que la operación no se sella más que por la presencia de un adulto (la madre, por ejemplo) cuya palabra confirma el efecto de captación subjetiva" (Conté, 1997: 100).

Oscar Masotta (2015) destaca que "sólo el niño humano puede acceder a la imagen en tanto tal, lo que quiere decir que es capaz de desdoblar el espacio en imaginario y en real (...) a lo que saluda el niño es a su imagen especular" (Masotta, 2015: 62). Sin embargo, a esta edad, el niño se encuentra en un periodo de desfasaje, puesto que comporta tanto un adelanto mental como una inmadurez biológica. Lo que hay dentro del espejo, en verdad, aquello a lo que el niño accede es una oposición entre la unidad gestáltica de la totalidad de su propio cuerpo, en la imagen; y los datos propioceptivos que provienen de "sus vísceras, sus articulaciones, etc." (Ídem). Su representación sería la coexistencia de la unidad de la imagen con la atomización a nivel propioceptivo.

En efecto, si del lado de la imagen hay una unidad -la unidad imaginaria gestáltica especular: "mi figura" como una totalidad aprehensible ("estoy unificado")-; a su interior el infans se encuentra fragmentado, escindido. Por ello para Lacan:

...el estadio del espejo es un drama cuyo empuje interno se precipita de la insuficiencia a la anticipación; y que, para el sujeto, presa de la ilusión de la identificación espacial, maquina las fantasías que se sucederán desde una imagen fragmentada del cuerpo hasta una forma que llamaremos ortopédica de su totalidad - y a la armadura por fin asumida de una identidad enajenante, que va a marcar con su estructura rígida, todo su desarrollo mental...

(EE: 102- 103)

Sin embargo, el movimiento que realiza el sujeto es el de defenderse de esa atomización, reprimiendo los datos propioceptivos para alienarse en su unidad imaginaria. Una de las manifestaciones de este estadio es que el niño da grandes sacudidas de cabeza como para capturar la unidad de su propia imagen en el espejo, "al niño se le ilumina la cara, sonríe con alegría ante la aparición de esa imagen suya especular" (Masotta, 2015: 58). Según Lacan- en la lectura de Masotta- aquí aparecen dos vectores fundamentales: por un lado, la capacidad de desdoblar el campo en real e imaginario o, en otros términos, la capacidad de otorgar al espacio imaginario estatuto de tal; por otro lado, la inmaduración biológica en ese momento del desarrollo. 
De esta manera, se constituye una matriz donde coexisten la anticipación mental (porque es capaz de esa gran escisión) y la premaduración biológica. Mientras en el nivel imaginario del espejo me percibo como unificado, en el nivel propioceptivo de mi propio cuerpo me percibo como atomizado. Y, "ante este cuerpo autoperceptivo atomizado, lo reprimo para alienarme completamente en la unidad de la imagen gestáltica especular" (Ibíd.: 59). De acuerdo con esta lectura de Masotta, como efecto de esta atomización aparece la oposición entre la unidad constitutiva narcisista de la imagen omnipotente y la verdad de esta imagen, que es el cuerpo despedazado.

En este sentido, el desdoblamiento del espacio en imaginario y real, estaría en la base de toda cultura. "Del mismo modo que no hay sociedad humana sin lenguaje: no puede haber sociedad humana alguna sin imágenes. La imagen está en la base del lenguaje" (Ibíd.: 63). Por ello es que, Lacan llama a esta instancia la matriz formadora del yo. Ya que por medio de esta capacidad del niño de distinguir fuera de él una forma gestáltica, que es la suya, se constituye la matriz de un yo que desde entonces va a ser la alienación del sujeto en esa imagen especular y "la represión de los datos del desmembramiento corporal" (Ibíd.: 64).

Esto constituye la prueba en cuyo transcurso se descubre que por otra parte sea llevado a cabo un desarrollo cognitivo cuya finalidad es la toma de conciencia de la realidad tal como es. El hecho de que el niño no acceda inmediatamente al modo de conocimiento adulto es juzgado como un defecto atribuido a una disfunción y destinado a su superación. En el caso del espejo, para el niño se trata de "conseguir unificar su yo en el espacio", ilusoriamente, en una aparente unidad. Esta apariencia de unidad se asemeja a la que subyace, según la lectura que Montag hace de Spinoza, en las tradiciones interpretativas cuando afirman que el desorden y el conflicto interno, es meramente aparente de la Escritura, ya que esta tendría una unidad sin fisuras, además de coherencia interna y doctrinal. Pero Spinoza, hace "una defensa contra cualquier reconocimiento del texto tal como es: desordenado, incompleto y defectuoso" (Montag, 2005: 36).

El reconocimiento entonces, está íntimamente ligado a la noción de identidad ya que el sujeto se reconoce como "un yo" y vive en la creencia de que él es la fuente de sí mismo, circunstancia que se le presenta como evidente. Sin embargo, este reconocimiento ante "lo evidente" implica inevitablemente el desconocimiento que asegura la sujeción, 
Supongamos que es necesario al orden social reinante que todos los miembros de la sociedad, sean dominadores o dominados, acepten libremente ciertas evidencias, como la existencia de Dios, una moral trascendente, la existencia de la libertad moral y política, etc., o de mitos muy diferentes, más simples o más complicados; si tal fuera el caso veríamos surgir, sin que nadie sea propiamente su autor, un sistema de representaciones que sería a la vez verdadero, en la medida en que tendría en cuenta realidades vividas por las personas, y falso, en la medida en que impondría su verdad a esas verdades, para conferirles su sentido verdadero y confinarlas a ese único sentido, con la prohibición de salir de él para ir a ver un poco más de cerca si toda esa bella historia es verdadera. Esto sería la ideología conocimientodesconocimiento, ilusión- alusión...

La efectividad de la interpelación ideológica implica el reconocimiento por parte del sujeto que tiene como contrapartida, el desconocimiento del funcionamiento de sus mecanismos -el "desconocimiento de las causas que llevan a los hombres a apetecer" (SM: 305) refiriendo a la Ética, I. Como consecuencia de este desconocimiento se posibilita el reconocimiento del sujeto en la imagen especular que lo constituye en un yo fragmentado. Para Pêcheux (2016) es en este reconocimiento que el sujeto ha olvidado las determinaciones que lo constituyen como tal -siendo siempre ya sujeto- lo que explica el carácter necesario del sujetamiento ideológico (p. 151).

Efectivamente, la necesidad del mecanismo de la interpelación es un aspecto que queda oculto, lo que configura un momento de desconocimiento dentro del reconocimiento. Este desconocimiento -que estructura la forma ilusoria del sujeto- es inherente a la construcción de la propia identidad (proceso de identificación) del individuo, que implica un sujetamiento (assujetissement) a lugares y posiciones que el sujeto percibe como elegidos autónomamente. Pero, ¿cómo opera concretamente este reconocimiento/ desconocimiento? En la entrevista que le realiza Fernanda Navarro, Althusser señala lo siguiente:

-FN: “¿Pero podría explicar cómo la conciencia de un individuo concreto puede ser dominada por una idea o sistema de ideas? Una primera respuesta podría ser que ese mecanismo se efectúa cuando la conciencia reconoce a esas ideas como "verdaderas" ¿Cómo se opera ese reconocimiento?

-A: ocurre "como si" al creer en una idea (o sistema de ideas) no fuera yo el que la reconociera y ante su presencia pudiera afirmar "ésa es, ahí está y es verdadera"; sino todo lo 
contrario: ocurre "como si" al creer en una idea, la idea fuera la que me dominara y me impusiera el reconocimiento de su existencia y de su verdad, a través del encuentro con su presencia. Todo ocurre "como si" —invertidos los papeles — fuera la idea la que me interpelara a mí y me impusiera el reconocimiento de su verdad. Es así como las ideas que constituyen una ideología se imponen a las "conciencias libres" de los hombres, al interpelar a los individuos de forma tal que se vean obligados a reconocer libremente que esas ideas son verdaderas; que, por

lo tanto, están obligados a constituirse en sujetos libres, capaces de reconocer la 'verdad' ahí donde se presenta, es decir, en las ideas constitutivas de la ideología. Este es, en síntesis, el mecanismo de la práctica ideológica; el mecanismo de la interpelación ideológica que transforma a los individuos en sujetos.

(F y M: 64)

Hasta aquí entonces, hemos examinado que la ideología desde esta perspectiva materialista, involucra una lógica de reconocimiento/ desconocimiento, que asegura que los sujetos se reconozcan en los rituales del reconocimiento ideológico que garantizan que somos sujetos irremplazables, únicos e idénticos (“...se los llama por su nombre, reconociendo que ellos son siempre ya interpelados como sujetos dotados de una identidad personal"). En este proceso de subjetivación, de construcción de la identidad (proceso de identificación), la falta en el sentido lacaniano, tiene un estatuto central.

\section{¿Sujetos libres, sujetados o agentes?}

La representación es la representación de una completud real que siempre está más allá de nuestro alcance. (Stavrakakis, Lacan y lo político)

De acuerdo con la exposición de la interpelación ideológica en el ensayo de 1970, una vez hecho evidente el mecanismo ideológico material que constituye un individuo como sujeto, no puede darse ninguna desarticulación, ni existe la posibilidad de un retorno a un estado inicial porque siempre ya somos sujetos. De manera que la forma que adquiere la subjetivación es simultáneamente de sujeción- sometimiento a las determinaciones materiales "de las relaciones sociales de producción, de las relaciones políticas de dominación y de la ideología misma” (De Ipola, 2007: 138).

De allí el aspecto imaginario de la autonomía y de la libertad del sujeto para escoger sus proyectos $-\mathrm{y}$ de actuar acorde a estos- ya que se prescriben con 
anterioridad. Lo que ocurre es que el individuo- sujeto ${ }^{86}$ constituido por una ilusión de libertad adquiere una aparente unidad de su ser que le permite actuar como sujeto (libre). Sin embargo, siguiendo a Spinoza sólo puede llamarse librea "aquella cosa que existe por la sola necesidad de su naturaleza y se determina por sí sola a obrar. Necesaria, en cambio, o más bien, coaccionada, aquella que es determinada por otra cosa a existir y a obrar según una razón cierta y determinada” (E, I, def. 40).

Es la interpelación la que exige y ordena a los individuos para que se comporten como sujetos para ser incluidos entre los sujetos. Y estos se relacionan imaginariamente con su posición de sujeto, que se les presenta como autónomamente construida, cuando en realidad, está siempre ya establecida. El carácter constitutivamente imaginario de la relación que establecen los sujetos con sus condiciones reales de existencia, es subrayado por Althusser en la segunda tesis de Ideología y aparatos ("tal relación es el punto central de toda representación ideológica; por lo tanto, imaginaria, del mundo real").

Si bien para Ernesto Laclau (2000) la noción de falta está ausente en la teoría de Althusser; desde nuestra perspectiva esta se encuentra en estado latente en la formulación althusseriana de las representaciones imaginarias que los sujetos establecen con las condiciones en que viven, estrechando fuertes vínculos con la noción de sujeto lacaniano. De acuerdo con el análisis de Yannis Stavrakakis en la noción de sujeto lacaniano, hay una falta constitutiva que este intenta recubrir en el nivel de la representación, en actos de identificación; sin embargo, ese recubrimiento lejos de eliminar esa falta, la hace resurgir. En las propias palabras de Stavrakakis:

La noción de sujeto en Lacan no sólo invoca la falta sino también todos nuestros intentos de eliminarla, que, no obstante, no cesa de resurgir. Aquí desplazamos nuestra atención desde el sujeto de la falta hacia los intentos del sujeto de representarse a sí mismo, siendo estos dos momentos dos caras de la misma moneda que revelan la dialéctica entre el sujeto y lo social en la teoría lacaniana. Es precisamente la naturaleza de la identificación lo que reproduce esta falta dentro de la estructura subjetiva. El sujeto encuentra la falta y la alienación allí donde

\footnotetext{
${ }^{86}$ Para De Ipola, Althusser no desarrolla ni explica el estatuto teórico de la categoría "individuo" pero intentaría reponer este silencio en la entrevista que le realiza Fernanda Navarro allí Althusser sostiene que, en la historia presente, en una coyuntura singular, "no existen más que casos e individuos singulares" (F y M, 36- 38. El resaltado es nuestro.). recurriendo a Wittgenstein "el mundo es todo lo que es el caso". Esta tesis fundamental del nominalismo, lo sería también para el materialismo (De Ipola, 2007: 152). Desarrollaremos en el siguiente capítulo el desarrollo frondoso de esta distinción entre individuo/ sujeto en las lecturas de Zizek y de Pêcheux, respectivamente.
} 
busca la completud y la identidad. Tiene que haber quedado claro que esta concepción no reduccionista de la subjetividad abre el camino para una primera confluencia entre la teoría lacaniana y el análisis político. La constitución (finalmente imposible) de toda identidad puede intentarse solo a través de procesos de identificación con construcciones discursivas socialmente disponibles como ideologías, etc.

(Stavrakakis, 2007: 63- 64)

Siguiendo por esta dirección de análisis, la efectividad de la dimensión imaginaria en la estructura de la ideología es tal que esta pasa a estar sostenida por una falta. Entonces bien, ¿existe posibilidad para el sujeto de escapar a la estructura ideológica? Hemos examinado que en la propuesta de Althusser existe una relación de inmanencia entre la ideología y las prácticas, ya que la ideología debe reproducir un tipo específico de prácticas sociales, las requeridas para que el sistema garantice la reproducción de la ideología de las clases dominantes. En esta dirección, cabe señalar que, en 1984 en la entrevista con Fernanda Navarro, Althusser refuerza la relación orgánica de las prácticas ideológicas y la estructura social:

Las prácticas sociales y las ideas que los hombres se hacen (de las prácticas) están ligadas estrechamente. Puede decirse que no hay práctica sin ideología, y que cualquier práctica, incluso científica, se realiza a través de una ideología. En todas las prácticas sociales, (ya correspondan al dominio de la producción económica, al de la ciencia, el arte o el derecho, al de la moral o al de la política), los hombres que actúan están sometidos a las ideologías correspondientes, independientemente de su voluntad y lo más a menudo con una total ignorancia del asunto.

La inmanencia entre ideología y práctica, implica otra relación de inmanencia, la de la ideología con los sujetos o agentes que ejecutarán esas prácticas. Yoshihico Ichida afirma que, "si ese sujeto o esos sujetos no son sino agentes de producción definidos completamente por las relaciones de producción, es decir, reducidos al lugar y a la función que tienen que cumplir, no hay ningún cambio entre la práctica como "estructura" o la práctica como "ideología" (Ichida, 2007: 75) ${ }^{87}$.

\footnotetext{
${ }^{87}$ Ichida complejiza aún más la cuestión y señala que "las 'relaciones de producción' no constituyen ya al sujeto, contrariamente a la declaración de Lire le Capital. Que determinen siempre exigencias a las que el sujeto constituido debe responder, no asegura ya que ese sujeto exista. El "ser" y el "qué hacer" del sujeto
} 
Althusser señala al respecto que no es él, sino el sistema capitalista y sus relaciones sociales el que concibe a los individuos como meros soportes de la estructura económica: "el sujeto no juega el papel que él cree sino el que le es asignado por el mecanismo del proceso" (PLC: 22). Más precisamente:

los verdaderos sujetos (en el sentido de sujetos constituyentes del proceso) no son, pues, esos ocupantes ni esos funcionarios, no son, por tanto, contrariamente a todas las apariencias (...) los individuos "concretos", "los hombres reales”; sino la definición y la distribución de sus plazas y de sus funciones. Los verdaderos "sujetos" son, pues, esos definidores y esos distribuidores: las relaciones de producción (y las relaciones sociales, políticas e ideológicas). Pero como son "relaciones" no se debería pensar en la categoría de

Lo cual coincide con lo expuesto en la Respuesta a John Lewis donde Althusser afirma que, en cuanto agentes, los individuos humanos no son sujetos "libres" y “constituyentes", en el sentido filosófico de esos términos. Sino que actúan en y bajo las determinaciones de las formas de existencia histórica de las relaciones sociales de producción y de reproducción. Ya que todo individuo humano, es decir, social, sólo puede ser agente de una práctica si reviste la forma de sujeto. Y "la forma- sujeto es la forma de existencia histórica de todo individuo agente de prácticas sociales, puesto que las relaciones sociales de producción y de reproducción comprenden las 'relaciones jurídico- ideológicas agentes- sujetos" (PPT: 77).

En este sentido, el concepto de agencia se demarca del abordaje de tipo humanista que exploramos en la primera parte, para pasar a ser comprendida como la ausencia de "sujeto" en las relaciones de producción. Por ello es que para Karczmarczyk (2016) la tesis del sujeto-sujetado no implica la eliminación de la agencia, sino sólo de aquella agencia que se entiende por referencia a un sujeto pensado como centro. Mientras que en Ideología...las relaciones de producción no son ya las que constituyen

son separados como dos problemas que las "relaciones de producción" estructurales no pueden resolver solos. También la "práctica" debe ser dividida en dos: por un lado, es siempre el "qué hacer" del sujeto en las relaciones de producción y, por otro, bajo el control de la ideología, puede y debe ligar ese "qué hacer" y el sujeto, garantizando a este último que "todo irá bien si los sujetos reconocen lo que son y se conducen en consecuencia". Al ser situada la ideología fuera de las relaciones de producción, la práctica del sujeto se hace doble respecto de aquello que debe asegurar por un sólo gesto práctico y tiende un puente entre el "ser" y el "qué hacer" del sujeto" (Ídem). 
a los sujetos como en Lire le Capital, sino que es la ideología la encargada de su constitución: "sólo se es sujeto por la práctica" (de la interpelación). La categoría de "sujeto" (que puede funcionar bajo otras denominaciones, por ejemplo, en Platón: el alma, Dios, etc.) es la característica constitutiva de toda ideología- "sólo en tanto toda ideología tiene por función (función que la define) la constitución de los individuos concretos en sujetos- cualquiera que sea su determinación (particular o de clase ${ }^{88}$ ), y cualquiera que sea su fecha histórica, puesto que "la ideología no tiene historia" (IAEI: $52)$.

Que la ideología sea eterna, y siempre ya haya interpelado a los individuos como sujetos (momento de la interpelación) y que los individuos sean siempre ya interpelados por la ideología como sujetos (momento del reconocimiento); implica que los individuos son siempre ya sujetos (Ibíd.: 57). Se trata de individuos abstractos respecto de los sujetos que son siempre ya, incluso antes de nacer por la configuración ideológica familiar en la que se insertará (“se sabe qué apellido llevará, que tendrá una identidad, y que será irreemplazable").

En otras palabras: dado que la ideología es eterna, el sujeto será desde siempre, un sujeto sujetado/ sometido a la estructura de la ideología; un animal ideológico (en el sentido spinoziano del término), porque "desde los inicios de los tiempos podemos constatar que el hombre ha vivido siempre bajo relaciones sociales ideológicas" (F y M: 65). En esa línea, cuando Navarro interroga a Althusser acerca de la posibilidad de pensar en la transformación de los sujetos "no sólo en el plano de la autoconciencia, sino de la conciencia de la realidad y de la necesidad de su transformación” (Ibíd.: 70), Althusser responde afirmativamente, argumentando que de otro modo no habría cambios ni tomas de posición que cuestionen y se opongan a lo establecido, lo dominante. 'No habría 'sujetos revolucionarios'. Pero un sujeto siempre es un sujeto ideológico. Su ideología puede cambiar de la dominante a la revolucionaria, pero ideología siempre habrá, ya que es condición de existencia de los individuos (Ídem.)

Entonces bien, la función- sujeto es central para lograr la reproducción de la ideología de las clases dominantes; y, asimismo, la eficacia de la ideología está garantizada de antemano por el acto circular que la caracteriza, puesto que produce sujetos, que siempre ya son sujetos. En otros términos: los agentes de reproducción de la

${ }^{88}$ Leeremos críticamente la "no mención" de la pertenencia sexo/genérica como una determinación básica. 
ideología (dominante) que debe reclutar, son los sujetos que ella misma constituye, en virtud de su circularidad.

En el marco de un sistema capitalista la constitución de un sujeto sujetado pareciera ser la única alternativa de constitución posible, ya que el mecanismo de la interpelación ideológica -que para Althusser es tanto de subjetivación como de sujeción- opera como condición de la constitución del sujeto, fuera del cual no serían posibles ni pensables las prácticas sociales. Sin embargo, hay una apertura por parte del planteo de Althusser a subvertir la sujeción, ya que las estructuras ideológicas y discursivas son políticas, móviles e históricas, comandadas en última instancia por la lucha de clases. Esto es algo que reconoce Laclau cuando afirma que "...la interpelación es concebida como parte de un proceso hegemónico articulatorio abierto y contingente que no puede ser confundido en ningún sentido con la "eternidad spinoziana"' (Laclau, 2000: 219-220).

En este escenario reestructurado de la estructura, se inscribe la dimensión ideológica en relación con las diversas prácticas (políticas, estéticas, filosóficas, científicas, etc.) y la constitución de diversas subjetividades, en las que tiene un estatuto central el registro de lo imaginario. Como muestra de estas múltiples subjetividades, consideramos que del hecho de que existan malos sujetos que no marchan solos, los rebeldes que no internalizan el mandato, se sigue que la atribución de libertad al sujeto no es siempre y en todos los casos el efecto retroactivo de una sumisión, sino que se abre la posibilidad de pensar en subjetividades agentes en las que operan otras modalidades de identificación como la contraidentificación y la desidentificación (que examinaremos en el último capítulo de esta segunda parte).

Siguiendo esta dirección, en Ideología y aparatos, el sujeto es entendido como efecto de procesos de interpelación ideológica, de manera que es constitutivamente ideológico, por lo tanto, se ubica en el registro de las relaciones imaginarias (vividas). Este efecto- sujeto (efecto de estructuras) es el portador de identidad, que se vive imaginariamente como identidad y que se ilustra con la evidencia de identidad ( yo”!). Para Pêcheux lo que está en juego en la noción de interpelación- identificación es la constitución de la subjetividad, pero él lo articula con el problema de la constitución del significado ${ }^{89}$ (" $\mathrm{X}$ " significa tal cosa...) atendiendo centralmente a aquella cita de

\footnotetext{
${ }^{89}$ Stavrakakis destaca que "Lacan propone que el significante tiene la primacía en la significación. Las leyes del significante son primarias, en su autonomía, en relación con la producción de sentido. La
} 
Ideología y aparatos... según la cual:

...Como todas las evidencias, incluso aquellas por las cuales una palabra "designa una cosa" o "posee una significación" (incluyendo por lo tanto las evidencias de la "transparencia" del lenguaje), esta "evidencia" de que ustedes y yo somos sujetos - y el que esto no constituya un problema- es un efecto ideológico, el efecto ideológico elemental.

(IAEI: 55)

Siguiendo a Lacan, Pêcheux afirma que lo que está en juego es la cuestión del sujeto como proceso de representación, un sujeto que está atrapado en la red de significantes (es decir, de aquello que representa el sujeto para otro significante) "de suerte que resulta de ella como 'causa de sí'” (Pêcheux, 2016: 140). Desde esta perspectiva, se produce un borramiento necesario en el interior del sujeto como "causa de sí", que tiene como consecuencia, según Pêcheux, la conformación de fantasmas metafísicos. Y que refuerza la imbricación entre la estructura de la ideología y la estructura del inconsciente que exploraremos a través de la referencia a escritos de Althusser sobre psicoanálisis.

\section{Freud y Lacan}

...la pretensión de la Ley humana que, como toda ley no es 'ignorada' por nadie, particularmente por quienes son ignorantes de ella, pero puede ser violada o desviada por todos, particularmente por sus puros fieles.

(Althusser, Freud y Lacan)

En "Freud y Lacan"-publicado por primera vez en La Nouvelle Critique, $\mathrm{n}^{\circ}$ 161/162, diciembre-enero 1964-1965- Althusser afirma que si Freud ya había afirmado que "todo dependía del lenguaje", Lacan va más allá y afirma que "el inconsciente está estructurado como un lenguaje" (EP: 38$)^{90}$. El estatuto central del lenguaje, se manifiesta asimismo en que todo lo que adviene en la cura se lleva a cabo en el lenguaje, y por el lenguaje (incluso el silencio, sus ritmos, sus escansiones). El lenguaje

significación es producida a través de las relaciones entre significantes, mediante la formación de cadenas lingüísticas, cadenas que remiten a otras cadenas..." (Stavrakakis, 2007: 94).

${ }^{90}$ Podemos observar de este modo cómo las adquisiciones más importantes de Saussure y de la lingüística entran en juego a la hora de justificar la prioridad de la estructura formal del lenguaje, y de sus mecanismos, encontrados en la práctica de la intervención analítica, en función misma del fundamento de esta práctica: su objeto, es decir, los efectos actuales de la humanización. 
es entonces, la materia prima de la práctica analítica - la que está fundada por derecho en su objeto que "fundamenta en última instancia tanto esta práctica como su técnica: luego, porque hay ciencia, en la teoría de su objeto" (Ibíd.: 39)- así como el medio de producción de sus efectos.

Ahora bien, el psicoanálisis operaría, según Althusser, una ruptura semejante a la que realiza Marx, afirmando que el sujeto humano está descentrado: "constituido por una estructura que no tiene más centro que el desconocimiento imaginario del 'yo', es decir en las formaciones ideológicas en que se reconoce como tal, y por las cuales deviene en sujeto humano" (Ibíd.: 47). Lo que refuerza, por un lado, la estructura de desconocimiento del inconsciente, y la tesis de que el sujeto no está dado previamente, sino que implica un devenir humano, pasaje que se efectúa desde "lo biológico" a "lo cultural" bajo el orden simbólico del lenguaje. Es por ello que para Althusser, "Lacan muestra la eficacia del Orden, de la Ley, que acecha desde antes de su nacimiento a toda criatura humana, y se apodera de ella desde su primer grito, para asignarle su lugar y su rol, es decir, su obligado destino" (Ibíd.: 41).

En la lectura que Althusser hace de Lacan, "lo disruptivo" de este último ha sido el haber mostrado la transición de la existencia biológica a la existencia humana bajo el orden de la cultura, cuya estructura formal comparte con el orden del lenguaje, y que se manifiesta porque "en esta asignación por el lenguaje de la cura, se transparenta la presencia actual, perpetua del eficaz absoluto del orden en la transición misma, de la ley de la Cultura en volverse humano" (Ídem.).

Bajo esta lectura, el ingreso del animal humano al orden de la Cultura ocurre en dos momentos: 1) el de lo imaginario en el que él mismo es ese otro (momento preedípico) que precede a lo simbólico. Es el momento en el que el pequeño vive una relación inmediata con un ser humano, la madre. Pero este no la reconoce aún como la relación simbólica que es, es decir, en su forma de un Orden formalmente idéntico al orden del lenguaje; 2) el de lo edípico en el que surge una estructura ternaria (padre) sobre el fondo de la estructura dual (madre- hijo) que lo trastoca, introduciendo al pequeño en el Orden Simbólico del lenguaje objetivo, y que lo constituye en niño humano.

Ambos momentos, señala Althusser, están regidos por la Ley de lo Simbólico. Sin embargo, Freud no puede ver esto porque hace una lectura superficial y guiada, viendo únicamente una "infancia feliz y sin leyes", "una especie de estado salvaje escondido únicamente por etapas de aspecto biológico, sujetas a la primacía funcional 
de tal parte del cuerpo humano, lugares de necesidades vitales" (Ídem.).

Sin embargo, es Lacan, según Althusser, el que con una mirada atenta muestra la eficacia del Orden simbólico y de la Ley de la Cultura ("que acecha desde antes de su nacimiento a todo ser humano"). Cuya forma es el lenguaje, pero no se agota en este ya que tiene como contenido las estructuras del parentesco reales y las formaciones ideológicas en las que los sujetos realizan su función. En este sentido:

No basta con saber que la familia occidental es patriarcal y exogámica (estructura del parentesco); también hay que poner en claro las formaciones ideológicas que rigen la conyugalidad, la paternidad, la maternidad y la infancia: ¿qué es "ser esposo”?, "ser padre”, "ser madre", "ser hijo" en nuestro mundo actual? Sobre estas formaciones ideológicas específicas queda aún por realizarse todo un trabajo de investigación.

(EP: $41 . \mathrm{N} / \mathrm{T}$ )

Ahora bien, Althusser señala que el discurso de este Orden simbólico es la condición absoluta de cualquier discurso, se trata de un "discurso desde lo alto", el discurso del Otro: el discurso del inconsciente. El inconsciente, sostiene Althusser, es en cada ser humano "el lugar absoluto en el que su discurso singular busca su propio lugar; busca, falla y al fallar encuentra su propio lugar en (...) las negaciones de sus propias fascinaciones imaginarias" (Ibíd.: 42).

Cabe señalar aquí que, en nota del traductor se afirma que el deseo en tanto categoría fundamental del inconsciente, no es inteligible en su especificidad más que como el sentido singular del discurso del inconsciente del sujeto humano. Este deseo, se distingue radicalmente de la "necesidad" orgánica de naturaleza biológica ya que "entre la necesidad biológica y el deseo inconsciente no existe una continuidad de esencia, como tampoco existe una continuidad de esencia entre la existencia biológica del hombre y su existencia histórica" (Ídem).

Siguiendo el método del materialismo dialéctico de Marx en El capital, y siguiendo a Freud y Lacan, Althusser señala que no se puede ingresar a la realidad específica del deseo partiendo de la necesidad orgánica; del mismo modo que tampoco se puede ingresar a la realidad específica de la existencia histórica partiendo de la existencia biológica del "hombre". Sino que el método es inverso: es a partir de la historia que se puede conocer la especificidad de la existencia histórica del hombre; y es a partir del inconsciente que se puede comprender y definir el sentido mismo del deseo, 
diferenciándolo de las realidades biológicas que lo sustentan.

La eficacia del discurso del Otro, del discurso Amo es eficaz e implica una "larga marcha forzada" por la cual los sujetos internalizan los mandatos sociales proferidos por este discurso. Tal es así que, a partir del Edipo, por ejemplo, el significante falo es el que centra el orden simbólico. Como da cuenta la siguiente cita:

...En el Edipo el niño sexuado se vuelve niño humano sexual (hombre, mujer), y poniendo a prueba de lo Simbólico sus fantasmas imaginarios, y acabe, si todo "funciona", por volverse y aceptarse lo que es: niño o niña entre adultos, con sus derechos de niño en este mundo de adultos y, como cualquier niño, con pleno derecho de llegar a ser un día "como papá", es decir, un ser humano masculino con una mujer ( y ya no sólo como una madre), o “como mamá", es decir, un ser humano femenino con un esposo (no sólo un padre)...

De acuerdo con la lectura de Althusser, el drama de la castración, da cuenta de que todo se juega en la materia de un lenguaje formado anteriormente, y que se ordena en torno al significante falo $^{91}$. Cabe señalar que para Althusser, el Edipo no constituye una especie de sentido oculto que pueda reactivarse o superarse; sino que se trata de una estructura dramática -impuesta por la ley de la Cultura- a todo aquel "candidato, involuntario y obligado a la humanidad; una estructura que contiene en sí misma no sólo la posibilidad sino la necesidad de las variaciones concretas en las que existe, para todo individuo que puede llegar a su umbral, vivirlo y sobrevivirle" (Ibíd.: 45). En este sentido, el psicoanálisis, en su aplicación llamada su práctica (la cura) trabaja sobre los efectos concretos de esas variaciones que están estructuradas por la Ley misma de lo Simbólico. Por lo cual cabe preguntarse: “¿cuáles son las relaciones entre la estructura formal del lenguaje con las estructuras formales del parentesco?”.

Para Althusser, si desde Copérnico sabemos que la tierra no está en el centro del Universo; desde Marx, sabemos que el hombre no es el centro de la Historia. Mientras que Freud nos permitiría descubrir que el sujeto real "no tiene la figura de un ego centrada en el yo, no tiene más centro que en el desconocimiento imaginario del yo, es

\footnotetext{
${ }^{91}$ En el diccionario de psicoanálisis de Laplanche, Pontalis y Lagache se afirma que, siguiendo la tesis del artículo de 1923 sobre "la organización genital infantil de la libido" según la cual, en los dos sexos, durante la fase fálica, es decir, en el momento del acmé del Edipo, hay un solo órgano que cuenta: el falo (Laplanche et al, 2004: 14). En la parte III de este trabajo, desarrollaremos perspectivas feministas críticas del falocentrismo de Lacan.
} 
decir en las formaciones ideológicas en las que se reconoce" (Ibíd.: 47).

El descentramiento del sujeto es tal que su constitución se plantea bajo un proceso de sujeción al orden simbólico que acontece a través de un complejo pasaje de la naturaleza a la cultura en la etapa del Edipo, momento en que se marca el ingreso del sujeto en el orden Simbólico, bajo una estructura de desconocimiento.

De manera que la constitución de la individualidad humanase produce a través de la estructura formal del lenguaje y de sus mecanismos. Por ello es que Althusser afirma que, el hecho de "que sobreviva el niño humano, prueba que todos los hombres son para siempre amnésicos de la originaria falla orgánica" (Ídem). La humanidad, sostiene Althusser, olvida o simula no recordar haber librado una lucha que deben recorrer los niños humanos, sujetos "torcidos, rechazados, cada uno para sí mismo en la soledad y contra la muerte" (Ídem).

\section{Psicoanálisis y Ciencias Humanas}

...la Razón Occidental no tardó, tras años de desconocimiento, desprecio e injurias en concluir un pacto de coexistencia pacífica con el psicoanálisis, más que a condición de anexarlo a sus propias ciencias o a sus propios mitos...

(Althusser, Psicoanálisis y ciencias humanas)

En las conferencias dictadas por Louis Althusser durante los años 1963 y $1964^{92}$, las cuales se editaron bajo el título de Psicoanálisis y ciencias humanas (2014), Althusser plantea la pregunta en torno al lugar del psicoanálisis en relación con el campo de las ciencias existentes y, con la psicología, la que -según Althusser- se encuentra en el terreno de una problemática ideológica.

De acuerdo con la perspectiva althusseriana, a la pregunta por el pasaje de lo biológico a lo cultural, del ingreso por parte del "ser biológico" al orden cultural, la psicología respondería que se trata de la constitución del individuo en un sujeto psicológico, "y la psicología sería el punto de inserción del individuo humano en la cultura, es decir, en las relaciones humanas" (P y CH: 72). Mientras que el psicoanálisis, propone lo inverso: es la cultura la que antecede y hace posible a los seres biológicos

\footnotetext{
${ }^{92}$ Se trata de dos conferencias pronunciadas por Althusser en el curso del seminario sobre Lacan y el psicoanálisis, que tuvo lugar en la École Normale Supérieure durante el año 1963-1964. Como afirma Matheron, cuando Althusser organiza su Seminario sobre Lacan y el psicoanálisis ya ha publicado la mayor parte de los artículos que serán recogidos en Pour Marx; por el contrario, no hay todavía por así decirlo, nada escrito sobre el psicoanálisis.
} 
"ya que el pase de lo biológico a lo cultural es en verdad, el efecto de la acción cultural sobre lo biológico..." (Ídem). Este es, según Althusser, el gran descubrimiento de Lacan para quien la cultura siempre se precede a sí misma. “...es esta verdad fundamental la que encontramos en las reflexiones de Lacan" (Ibíd.: 82).

Ahora bien, el individuo biológico entra en relación con la sociedad para satisfacer sus necesidades naturales, de manera que lo social se establece como una continuación de lo biológico, como el efecto de la esencia misma de lo biológico, y lo biológico como el origen de lo social:

Lo que hemos aprendido de la interpretación de Lacan es que el psicoanálisis concierne al devenir humano del pequeño infans, es decir a la inserción en la cultura por los desfiladeros del significante, es decir por los desfiladeros de la cultura misma, y de la cultura a priori que condiciona toda culturación de este pequeño ser biológico que es un pequeño ser biológico humano. Este pequeño ser biológico deviene infans a partir el momento en que franquea la barrera del Edipo, a partir del momento en que se inserta en la maquinaria, es decir, en la repartición de papeles que le son impuestos por las estructuras del parentesco que se reflejan en el orden el significante, a través de cual se expresa su necesidad en forma de demanda.

Entonces bien, lo social sería la sumatoria interconectada de elementos individuales, unidos a partir de las necesidades naturales. Por tanto, en lo biológico se encontraría la causa de lo social. En otras palabras: lo biológico se vuelve fundamento de lo social, lo que significa también la proyección del sujeto social sobre el individuo biológico.

La individualidad y la subjetivación no pueden identificarse porque ello implicaría postular un subjetivismo que plantea lo biológico como el fondo instintivo que constituye la interioridad del sujeto, en una biologización del inconsciente. Lo que implicaría sostener una concepción del sujeto como una interioridad que se enfrenta a una exterioridad, que se relaciona intersubjetivamente mediante el lenguaje. Reduciendo lo psíquico a lo biológico ${ }^{93}$.

\footnotetext{
${ }^{93}$ Althusser compara la problemática ideológica de la psicología y la del derecho natural, y señala que la primera postula un sujeto biológico enmarcado en la relación entre naturaleza y cultura. Y la segunda, postula un origen, lo que Rousseau detecta y crítica tal como da cuenta Althusser (1972) en sus Cursos sobre Rousseau.
} 
Para Althusser, la psicología es una ideología del sujeto que produce una identidad (especular) entre el sujeto y sus necesidades, entre lo biológico y lo psicológico. Así, el individuo biológico deviene sujeto para satisfacer las necesidades ya establecidas en el campo de lo biológico. Este mecanismo tendría la forma de un círculo ya que contiene en sí mismo, en la forma de identidad, lo biológico y lo cultural. Un movimiento propio del tratamiento empirista del conocimiento. Desde la perspectiva althusseriana, en la psicología el orden de determinación aparece invertido, volviendo al individuo (en tanto soporte de una categoría económica) el origen de su lugar en la esfera productiva. Para Althusser, es esta inversión, "lo que conforma toda la paradoja de una psicología cuyo origen es manifiestamente político: el sujeto es el que está sometido a un orden, es el que está sometido a un amo, y que, al mismo tiempo, en la psicología se lo piensa como si fuera el origen de sus propias acciones” (Ibíd.: 94).

Ahora bien, mientras que en la ideología psicologista hay una identificación entre "individuo", "yo" y "sujeto", ya que tiene una estructura centrada en el ego; el psicoanálisis lacaniano, según Althusser, desarticula estos elementos en diferentes órdenes, y los funde en un solo objeto: el "yo" como producto de la alienación del sujeto en una unidad ficticia (función de desconocimiento-reconocimiento).

En este marco, el "individuo", por otra parte, sólo sería una categoría abstracta puesto que los individuos son siempre ya-sujetos, en tanto sujetos sociales. Para Lacan, en la lectura de Althusser, del mismo modo que el individuo biológico no es el antecedente causal del sujeto de lo simbólico, el individuo sólo es en la esfera productiva en tanto sujeto. De allí que, Althusser afirma que el objeto del psicoanálisis concierne al devenir humano del pequeño infans, es decir, de la inserción en la cultura a través de su tránsito por la cultura misma "por los desfiladeros del significante, es decir por los desfiladeros de la cultura misma, y de la cultura a priori que condiciona toda culturación" (Ídem). Este pequeño ser biológico deviene infans a partir del momento en que franquea la barrera el Edipo, es decir a partir del momento en que se inserta en el lugar que se le ha impuesto por las estructuras del parentesco que se reflejan en el orden del significante, a través del cual se expresa su necesidad en forma de demanda.

Siguiendo a Lacan entonces, Althusser señala que "el pase de lo biológico a lo cultural es en verdad, el efecto de la acción cultural sobre lo biológico" (Ibíd.: 29). La causalidad dominante en esta instancia se da desde lo histórico a lo biológico: "la cultura captura a los cachorros humanos y les asigna su lugar en su seno" (cfr. Karczmarczyk, 2014: 18). Por ello es que Althusser reconoce que el gran 
"descubrimiento" de Lacan es haber mostrado que el pasaje no es de la naturaleza a la cultura, sino justamente a la inversa: la cultura recluta al ser biológico, quien la antecede y a su vez, la hace posible. De manera análoga esta cuestión es retomada en el intercambio epistolar con su analista René Diatkine (en adelante Carta a D...) en 1966.

\section{Cartas a D...}

El vacio es el único modo de atrapar algo con el lenguaje.

(Lacan, Seminario 19)

En las Cartas a D... de 1966, publicadas en 1996 en Escritos sobre Psicoanálisis, Althusser quiere mostrar -en discusión con su psicoanalista René Diatkine- la especificidad del psicoanálisis; y demostrar que este rompe con las categorías ideológicas con las que trabaja la psicología, como las de la génesis y origen, a las que considera religiosas, en última instancia.

En ese sentido, Althusser reconoce positivamente que Diatkine intente mostrar que no es necesaria la realidad de la escena primitiva para que surja y funcione el fantasma de la escena primitiva, al igual que otros fantasmas; pero Althusser afirma que le parece una ilusión imaginaria pretender situar una línea divisoria entre un antes bioetológico, y un después en el que figura "algo radicalmente nuevo (el inconsciente) en el desarrollo mismo del niño" (EP: 58). Y más aún: advierte que, en el fondo, él (Diatkine) no renuncia totalmente a la idea de una génesis, lo que se manifestaría a través de ciertas "omisiones significativas" y deslices como el de hacer "aparecer el lenguaje en el niño -en el momento conveniente- para demostrar con este hecho una teoría" (...) pero para Althusser, combatir una verdadera teoría con un simple hecho, es como "atacar una fortaleza con una resortera" (Ibíd.: 68).

En efecto, desde la posición althusseriana, Diatkine no puede ver que ese lenguaje ya existe en el medio en el "que el niño aparece” (Ibíd.: 65). Con lo cual, Diatkine restituye una forma de empirismo ideológico que falsea la relación de la teoría con la experiencia: la “ideología 'espontánea' de todos los practicantes, sin importar su práctica" (Ibíd.: 69). Asimismo, Althusser detecta otras limitaciones en el planteo de su analista como la de no poder fechar el momento en el que surge en la historia del niño la nueva estructura que interesa al psicoanálisis: la del inconsciente. Y que defina a este 
último como memoria (como "reserva mnésica", etc.) al que Althusser considera "uno de los peores conceptos de la psicología" (Ibíd.: 62). Finalmente, frente a la pretensión psicologista - ideológica- de inscribir una división en la historia del desarrollo del niño, Althusser señala que el inconsciente, como el lenguaje es eterno, y funciona como este, bajo leyes.

Por su parte, en la carta 2 a D... Althusser refuerza sus argumentos contra el concepto de génesis y señalará que "quien dice génesis dice: reconstitución del proceso mediante el cual, en efecto, un fenómeno A fue engendrado" (Ibíd.: 73). En la práctica de los genéticos, según Althusser existe esta aplicación del concepto de génesis a través del fenómeno del engendramiento, ellos "se asignan la tarea de hacer la génesis de un fenómeno identificado siempre por adelantado, y quieren asistir y hacernos asistir al nacimiento de este individuo ya identificado" (Ibíd.: 75). Se trata de un falseamiento, de una ilusión retrospectiva, puesto que aquello cuyo nacimiento va a ser observado "ya lleva su nombre, posee ya su identidad, ya es identificable, y, por ende, en cierta medida ¡para poder nacer existe ya de alguna manera antes de su propio nacimiento! (Ídem).

En este marco, ¿cómo analizar el procedimiento de esta ilusión retrospectiva? Para Althusser, siguiendo el camino ya señalado por Marx en la Introducción y en El Capital, se parte de lo abstracto a lo concreto, evitando el error de confundir el proceso de conocimiento con el proceso real. En este sentido, retorna a la cuestión del surgimiento de la sociedad capitalista y sostendrá que no hay filiación entre los modos de producción feudal y capitalista. Sino que este último surge del encuentro ${ }^{94}$, de la combinación (Verbindung) ${ }^{95}$ específica de ciertos elementos. En este sentido, la sociedad feudal no engendra estos elementos, sino que esta combinación es posible por leyes muy diferentes del engendramiento, que no se pueden observar: "para llegar a estas leyes hay que renunciar a buscarlas en la proximidad inmediata del fenómeno A (...)" (Ibíd.: 80).

Para Althusser, hay que atender a los elementos indispensables para que su combinación funcione realmente como modo de producción capitalista (la existencia de capital acumulado; la existencia de una masa de trabajadores; el desarrollo de determinas técnicas). Y parafraseando a Marx, señala que todo modo de producción es eterno, ya que una vez instaurada la nueva estructura, es intemporal, funciona en circuito cerrado como la estructura del inconsciente y la estructura de la ideología.

\footnotetext{
${ }^{94}$ Sobre el "materialismo del encuentro" me remito a la parte I de este trabajo.

${ }^{95}$ Que también podría ser pensada en términos de organización o agenciamiento.
} 
Ahora bien, ¿cómo se articulan estas dos instancias (la del inconsciente y la de la ideología)? Althusser se aproxima a esa respuesta mediante dos tesis: 1) el inconsciente está estructurado como un lenguaje, en alusión a las leyes de combinación que rigen los mecanismos de los significantes; 2) “el niño está atrapado en el lenguaje desde su nacimiento", es decir, atrapado en lo simbólico o más precisamente: "como ser biológico en el sistema de orden simbólico" (Ibíd.: 87).

En efecto, el lenguaje- que no es sinónimo de palabra porque esta es una de las modalidades concretas de existencia de la lengua como estructura (tanto como sistema de fonemas como sistema de morfemas) que constituye la condición de posibilidad de todas sus formas y modalidades de existencia concretas de la lengua, entre las cuales figura la palabra- es el que "que atrapa al sujeto", el orden simbólico. El orden simbólico, según Althusser, es una estructura sometida a leyes que implica el pasaje entre dos estratos diferentes, lo que es ilustrado por Althusser de la siguiente manera "el niño surge como ser biológico en el sistema del orden simbólico. Está atrapado en él desde su nacimiento exactamente como atrapado está "desde su nacimiento en el elemento de la atmósfera (...) sus intercambios con la atmósfera se zanjan biológicamente" (Ibíd.: 87). Para Althusser, es necesario sostener con fuerza las dos puntas de la cadena. La primera punta es que el niño es arrojado a un mundo que está estructurado por el lenguaje: el niño nace pequeño animal lanzado a un mundo estructurado por el orden simbólico y sus regiones" (Ídem).

La segunda, es que el niño está atrapado desde que nace, y antes inclusivo, en el orden simbólico. En este marco, el medio familiar está compuesto, dentro del orden simbólico, por las estructuras familiares antes mencionadas y sus reglas de relación, y por la parte constituida por las formas ideológicas existentes en las que se viven concretamente las estructuras del parentesco consideradas (la forma ideológica de la pareja, de la maternidad, la forma ideológica de la niñez, y todas las formas ideológicas morales, jurídicas y religiosas, con todas sus relaciones positivas-negativas (Ibíd.: 89). Es decir que, el orden simbólico ocupa su lugar en el niño a partir de la dimensión inconsciente que es una de las condiciones indispensables para que el niño actúe de acuerdo con lo previsto es decir como "humano". Althusser sostiene y comprueba la hipótesis de Lacan de que las estructuras del lenguaje (de lo simbólico) desempeñan un papel determinante en los mecanismos que desembocan en el surgimiento del inconsciente.

Al comparar las dos tesis mencionadas, Althusser pretende poner en evidencia 
que ambas comparten las estructuras de lo simbólico en general, confirmando "la hipótesis de Lacan de que las estructuras del lenguaje (lo simbólico) desempeñan un papel determinante en el surgimiento del inconsciente" (Ibíd.: 91). De manera que, el inconsciente funciona con la ideología, entendida esta última como una estructura imaginaria que incluye gestos, conductas, actitudes, intenciones, aspiraciones, rechazos, permisos, etc. No existe sólo bajo la forma de conceptos. Esto explica que "ciertas situaciones ideológicas mantengan de maravilla ciertas estructuras inconscientes definidas" (Ibíd.: 93). Ahora bien, la teoría materialista de la ideología de Althusser fue criticada por funcionalista, reproductivista y pesimista, en cuanto a la posibilidad de invertir la dominación ideológica de la burguesía. En esta línea, en el próximo capítulo examinaremos críticas realizadas a la interpelación ideológica en Ideología y aparatos... vinculadas a la circularidad de la ideología. Frente a estas críticas, argumentaremos que Althusser destaca que la primacía de la lucha de clases es incompatible con todo funcionalismo (primacía que es enfatizada en la propuesta de Pêcheux de comprender a los AIE como reproductores/ transformadores de las relaciones de producción). Así como mostraremos que, la propuesta de las Tres notas - además de reforzar la articulación central entre estructura de la ideología y estructura del inconsciente, pero desde una dimensión discursiva- permite entender la forma-sujeto no como una forma preexistente sino como una forma que debe ser puesta en funcionamiento en cada caso singular. 


\section{Capítulo VI. Críticas a la interpelación ideológica}

[Althusser] confiere a la ideología un estatuto de realismo materialista, un estatuto de ontología social, al mismo tiempo que la plantea como una "interpelación" por la cual todo el mundo es convocado y socialmente constituido como sujeto...

(Jacques Bidet, "Introducción” a Sobre la reproducción)

En este capítulo proponemos examinar que las perspectivas críticas de Zizek y de Butler en torno a la interpelación ideológica propuesta en Ideología y aparatos...ven en la falta de agencia de los sujetos sujetados, la falta de consideración de la dimensión inconsciente, en el caso de la crítica de Zizek; y la ausencia de referencia al elemento pasional del mecanismo psíquico, en el caso de la crítica de Butler.

Frente a estas críticas, argumentaremos que estas pueden ser disipadas atendiendo a tesis transversales de la intervención materialista de Althusser en la que tiene primacía la lucha de clases, la sobredeterminación de determinaciones que permite pensar en la transformación de las relaciones de producción y en múltiples interpelaciones. Así como, pueden ser disipadas al atender a la articulación central entre la estructura de la ideología y la estructura del inconsciente.

Examinaremos en este sentido, la propuesta de Pêcheux, que evaluaremos como una alternativa frente a los problemas que se presentan en el ensayo de 1970. 


\section{Zizek y su lectura de los sujetos siempre ya interpelados}

En cuanto se pierde la creencia, la trama de la realidad social se desintegra. (Zizek, El sublime objeto de la ideología)

En el Sublime objeto de la ideología ([1989] 2003) Slavoj Zizek afirma que Althusser no analiza la internalización del llamado ideológico emitida por el AIE, (el "llamado externo" de la interpelación ideológica) y la subjetivación/identificación. A raíz de lo cual, Zizek plantea lo que considera una pregunta no planteada: ¿cómo el sujeto internaliza las prácticas que prescriben los AIE? ¿Por qué la interpelación ideológica da por hecho, o implica de antemano que el individuo responde al llamado?

Frente a estas fallas de la teoría althusseriana, según el filósofo esloveno "la versión más elaborada de la teoría de la interpelación” es la que nos da Michel Pêcheux" (SOI: 25) quien detecta los efectos del cortocircuito entre la interpelación y la respuesta a ese llamado cuando afirma que "no es raro que te interpelaran como proletario cuando lo que eres es un proletario". En analogía, Zizek evoca un famoso chiste para dar cuenta del carácter ilusorio del proceso de interpelación/reconocimiento:

- "Me recuerdas a Emanuel Ravelli:

-pero es que yo soy Emanuel Ravelli

- Entonces es raro que te parezcas a él".

Siguiendo a Pêcheux, Zizek señala que es el individuo (no el sujeto) el que es interpelado por la ideología para eludir la presuposición de la existencia del sujeto sobre el cual se ejerce la interpelación. En esta línea, la anterioridad que supone la categoría de "individuo" respecto a la categoría de "sujeto" -dado que los individuos son siempre ya interpelados por la ideología (reconocimiento)- involucra en realidad, un reconocimiento falso.

Para Zizek, el mecanismo de reconocimiento mediante el cual, el "sujeto" se "reconoce" como el destinatario del llamamiento de la causa ideológica, está predeterminado y es inevitable: "cuando nos sometemos a la máquina de un ritual religioso, ya creemos sin saberlo, que nuestra creencia está materializada en el ritual externo; en otras palabras: ya creemos inconscientemente" ... (Ibíd.: 73). Reconociendo que la fórmula de Pascal: “Arrodíllense, muevan los labios en oración, y creerán” es una de las referencias centrales de la propuesta althusseriana en Ideología y aparatos..., Zizek señala que es la que le permitiría a este último mostrar que las creencias de un individuo son materiales en tanto que tienen como correlato la realización de actos 
materiales insertos en prácticas concretas, reguladas por rituales materiales que se definen en los AIE materiales, por el cual circulan las ideas del "sujeto".

Zizek reconoce que el automatismo de Pascal se encuentra en la base del planteo de Althusser, el que, sin embargo, hablaría únicamente del proceso de interpelación ideológica a través de la máquina simbólica de la ideología que internaliza; dejando a un lado la pregunta acerca de cómo se internaliza el AIE (la máquina pascaliana externa, el automatismo significante). En efecto, en su planteo de la interpelación ideológica, Althusser -según Zizek- no explicaría cómo se produce el efecto de creencia ideológica en una Causa y cómo se produce el efecto interconexo de subjetivación, de reconocimiento de la propia posición ideológica" (Ídem.).En otras palabras, la asimilación del mandato ideológico en el inconsciente no aparece, según lo ve Zizek, desarrollada en el esquema de Ideología y aparatos... no pudiendo explicar el vínculo que une al sujeto subjetivado con la ideología.

Si en la propuesta de Althusser, los AIE son una máquina externa que ejercen su fuerza sólo en la medida en que se experimenta en la economía inconsciente del sujeto como un "mandato traumático, sin sentido" (Ídem); para Zizek, la máquina simbólica pascalina no es simplemente externa, sino que representa y decide de antemano nuestras creencias internas más íntimas: "La creencia es un asunto de obediencia a la letra muerta e incomprendida. Este cortocircuito entre la creencia íntima y la "maquina" externa es el meollo más subversivo de la teología pascalina" (Ídem). En efecto,

... sabemos por Pascal que esta "internalización" por necesidad estructural, nunca se logra plenamente, que siempre hay un residuo, un resto, una mancha de irracionalidad traumática y sin sentido adherida a ella; y que este resto, lejos de obstaculizar la plena sumisión del sujeto al mandato ideológico, es la condición misma de ello...

(SOI: 74)

Entonces bien, la dificultad que presenta la interpelación althusseriana en el marco del ensayo de 1970 -para Zizek- consiste en la anterioridad que supone el proceso por el cual el sujeto deviene "lo que ya era siempre: un efecto retroactivo que se vive como algo que ya estaba desde el comienzo" (SOI: 146). El proceso de interpelación ideológica por medio del cual el sujeto "se reconoce" como el destinatario del llamamiento de la causa ideológica implica necesariamente, una ilusión.

En este sentido, Zizek lee en la teoría althusseriana de la ideología, una variante 
de reproductivismo y señala que Althusser en su formulación de la interpelación ideológica se centra únicamente en el aspecto estructural de la relación entre la ideología y la subjetividad. Pero no lo explica desde el punto de vista del "sujeto". No existiría entonces, desde su perspectiva crítica, un tratamiento de la internalización. Y, además, la internalización del discurso del Otro sería entendida como acabada y completa. Pero, para Zizek, el sujeto no puede ser representado por un solo significante, sino por varios, o por ninguno, estableciendo relaciones con el mundo no determinadas previamente. Tal como ocurre con el sujeto de El Proceso de Kafka donde:

...El sujeto kafquesco es interpelado por una misteriosa entidad burocrática (Ley, Castillo). Pero esta interpelación tiene un aspecto extraño: es por así decirlo, una interpelación sin identificación/subjetivación; no nos ofrece una Causa con la que identificarnos. El sujeto kafquesco es el sujeto que busca desesperadamente un rasgo con el que identificarse, no entiende el significado de la llamada del Otro.

(SOI: 74)

Esa es la razón por la cual para Zizek, Kafka hace a Althusser una especie "de crítica avant la lettre" ya que permite ver aquello que es constitutivo de la brecha entre la "máquina” y su “internalización”. De allí que Zizek pregunte retóricamente: “¿No es la burocracia 'irracional' de Kafka, este aparato ciego de Estado con el que se confronta un sujeto antes de cualquier identificación, cualquier reconocimiento- cualquier subjetivación- tenga lugar?” (Ídem.).

En efecto, el sujeto kafquesco no se identifica con los aparatos judiciales del aparato burocrático que lo interpelan, por tanto, no se identifica con la ideología dominante. Se trata de una figura que le permite a Zizek problematizar la interpelación ideológica presentada por Althusser, argumentando junto con Lacan que la representación simbólica siempre deforma al sujeto, que este es siempre un desplazamiento, un fracaso, que no puede encontrar un significante que sea el "suyo".

De acuerdo con la perspectiva de Zizek, la dimensión que pasa por alto la explicación althusseriana de la interpelación ideológica es que -antes de ser cautivo de la identificación, del reconocimiento/ falso reconocimiento- el sujeto (barrado) es atrapado por el Otro mediante una fantasía ideológica que estructura y soporta la realidad. Siguiendo a Lacan, Zizek argumenta contra Althusser, que en el proceso de la interpelación ideológica existe un sujeto dividido, un sujeto ya interpelado en tanto 
sujeto. En este sentido, Zizek propone completar el análisis del discurso con la lógica del goce, esto es: analizar los significantes flotantes y la intervención de puntos nodales en un campo ideológico determinado, pero también dar cuenta de cómo "una ideología implica, manipula, produce un goce pre- ideológico estructurado en fantasía” (Ibíd.: 76).

Lo que pretende mostrar Zizek, contra Althusser, es que "el sujeto trata de articularse en una representación significante, pero la representación fracasa, en vez de una riqueza tenemos una falta; y este vacío abierto por el fracaso es el sujeto del significante" (Ibíd.: 228). Este sujeto es precisamente ese fracaso, esta es para Zizek, su verdadera condición.

En la argumentación del filósofo esloveno, la figura del point de capiton juega un rol central puesto que funciona como un significante rígido que mantiene su identidad a través de todas las variaciones de su significado, es decir, que totaliza el campo ideológico mediante la operación de "acolchado que fija su significado" (Ibíd.:141). Este point de capiton representa el Gran Otro que fija retroactivamente el significado de los elementos precedentes, es el "punto a través del cual el sujeto es 'cosido' al significante; y al mismo tiempo, el punto que interpela al individuo a transformarse en sujeto dirigiéndole el llamado de un cierto significante amo ('Comunismo', 'Dios', 'Libertad', etc.)” (Ibíd.:141- 142). Este significante Amo -que es el punto de subjetivación de la cadena significante- se articula con su acolchado ideológico que se compone de otras formaciones discursivas que le son afines como podrían ser: "familia", "trabajadores", "sacrificio", etc. Y será el significante "el que constituye el núcleo de la identidad del objeto" (Ibíd.: 142).

Ahora bien, si para Zizek, la aglomeración de significantes flotantes, de elementos protoideológicos, está estructurada en un campo unificado a través de la intervención de un determinado punto nodal (el point de capiton lacaniano) "que los acolcha, que detiene su deslizamiento y fija su sentido" (Ibíd.: 87); para Laclau y Mouffe lo conceptualizan en términos de puntos nodales. Como da cuenta la siguiente cita:

Si lo social no consigue fijarse en las formas inteligibles e instituidas de una sociedad, lo social sólo existe, sin embargo, como esfuerzo por producir ese objeto imposible. El discurso se constituye como intento por dominar el campo de la discursividad, por detener el flujo de las diferencias, por construir un centro. Los puntos discursivos privilegiados de esta fijación parcial los denominaremos puntos nodales. (Lacan ha insistido en las fijaciones 
parciales a través de su concepto de point de capiton, es decir, de ciertos significantes privilegiados que fijan el sentido de la cadena significantes (...). (Laclau y Mouffe, 1985: 112. Citado por Stavrakakis, 2007: 121)

Efectivamente, en la lectura que Zizek hace de Lacan, este último acentuaría el carácter retroactivo del efecto de significación con respecto al significante, por ello "el efecto de sentido se produce siempre hacia atrás, après coup. Los significantes que están todavía en estado de "flotación" -cuya significación no ha sido fijada- siguen uno al otro" (SOI: 143). Zizek propone entonces comprender que en el espacio ideológico "flotan" significantes como "libertad", "Estado", “justicia", y entonces la cadena significante se complementa con algún significante amo (por ejemplo "Comunismo"), que retroactivamente fija el significado ("Comunista") de aquellos.

De este modo, siguiendo a Lacan, Zizek señala que por "el efecto de retroversión", el sujeto se transforma en cada etapa en lo que ya era siempre": un efecto retroactivo "que vive como algo que ya estaba allí" (Ibíd.: 146). El resultado de este proceso es la identificación simbólica: "la identificación del sujeto con alguna característica significante, rasgo (I), del gran Otro, en el orden simbólico" (Ídem). Por ello Lacan define al significante como aquel que "representa al sujeto para otro significante; asume una forma concreta, reconocible en un nombre o en un mandato que el sujeto toma a su cargo y/o se le otorga" (Ídem).

Ahora bien, siguiendo a Freud y a Miller, Zizek distingue entre identificación simbólica -la identificación con el ideal del yo (Ich-ideal), "con el lugar desde el que nos observan" (ibíd.: 147)- de la identificación imaginaria -la identificación con el yo ideal (Idealich)- que se encuentra en un nivel que conecta el yo imaginario y su otro imaginario "para lograr la identidad propia" (Ídem). Precisamente es en este nivel imaginario que se ubica el "efecto de retroversión", dado por la ilusión del yo como agente autónomo, y constituyente de sus actos. Pero, para Zizek, Althusser no toma en cuenta una instancia del sujeto que no pase por la identificación ni por la subjetivación: un núcleo, un resto de irracionalidad que constituye al sujeto. Se trata de un vacío que hace al sujeto impermeable a las identificaciones con el exterior y que conforma una dimensión relevante y estructural del sujeto que es la del deseo, el goce y la fantasía.

En esta dirección, el núcleo del sujeto estaría más bien en enfrentamiento con las interpelaciones e identificaciones, consideradas en este marco como mecanismos de fuga mediante los cuales el sujeto esquiva la asunción de su deseo. En los propios 
términos de Zizek: se esquiva la respuesta a la pregunta que se le formula al sujeto acerca de su deseo: ¿Che voi? (Ibíd.: 153). Desde esta perspectiva, el proceso de interpelación - subjetivación es, un intento de evadir este núcleo traumático mediante la identificación. Por tanto, al asumir un mandato simbólico, al reconocerse en la interpelación, el sujeto elude la dimensión de la Cosa.

Antes de exhibir posibles respuestas frente a la crítica de Zizek, presentaremos la crítica de Judith Butler quien interpreta la interpelación del individuo transformado en sujeto por la intimidación ideológica, como el indicador de una adhesión apasionada que lo llama a los lejos" (Le Blanc, 2006: 49), pero Althusser según Butler "no enuncia las razones que llevan al individuo a reconocer la apelación ‘¡Eh tú, el que está allí!’” (Ídem).

\section{Butler y su lectura de los sujetos siempre ya apasionados}

La idea de que el sujeto está apasionadamente apegado a su propia subordinación ha sido invocada cínicamente por quienes intentan desacreditar las reivindicaciones de los subordinados.

(Butler, Mecanismos psíquicos del poder)

En Mecanismos psíquicos del poder ([1997] 2001) Butler comprende el proceso de constitución de los sujetos en términos de sujeción (subjection) ${ }^{96}$, esto es, como el proceso de devenir subordinado al poder, así como el proceso de devenir sujeto, a través de la internalización de normas y significaciones culturales de una sociedad. Para la filósofa feminista "ya sea a través de la interpelación, en el sentido de Althusser, o a través de la productividad discursiva, en el sentido de Foucault; el sujeto se inicia mediante una sumisión primaria al poder" (Butler, 2001: 12).

El sometimiento consiste para Butler justamente en esa dependencia fundamental ante un discurso que no hemos elegido, pero que sustenta nuestra potencia. Entonces, si la sumisión es una condición de la sujeción, Butler considera pertinente

\footnotetext{
${ }^{96}$ En Nota del traductor se aclara que "el término subjection que aparece en el título del libro y reiteradamente a lo largo del mismo, se puede traducir como sujeción o sometimiento. El segundo término me parece por lo general más adecuado, puesto que alude a los dos componentes del proceso, el activo (someterse a alguien), y el pasivo (someterse a alguien); mientras que la sujeción destaca el componente activo (sujetar a) y tiene, además, connotaciones de fuerza que no siempre son pertinentes en el contexto de los argumentos de Butler. Sin embargo, siguiendo el uso del término francés assujetissement por parte de Louis Althusser y de Michel Foucault, la autora utiliza subjection con el doble significado de sujeción y de subjetivación (el proceso de devenir sujeto) y uno de los argumentos centrales del libro es que el sujeto se forma en la sujeción" (N/T, p. 7).
} 
preguntar: “¿Cuál es la forma psíquica que adopta el poder?” (Ibíd..: 13). Y advierte que en este mecanismo psíquico intervienen deseos, vínculos apasionados y necesidades primarias, que funcionan, por ende, como constitutivos de la formación del sujeto.

Ahora bien, si Althusser y Foucault ${ }^{97}$ desde la vertiente externa del poder (Le Blanc, 2006: 48) acentúan el carácter productivo de toda relación de poder que tiene como resultado la función- sujeto; Butler -desde una vertiente interna "que no es más que la exhibición de la vida subjetiva revelada en la relación de adhesión con el poder" (Ídem)- señala que el sujeto no es sólo el blanco terminal efectuado en la relación de poder, sino que se efectúa a sí mismo en y por la relación de poder. En palabras de Butler:

...el poder forma al sujeto, le proporciona la misma condición de su existencia y la trayectoria de su deseo, entonces el poder no es solamente algo a lo que nos oponemos, sino también de manera muy marcada, algo de lo que dependemos para nuestra existencia y que abrigamos y preservamos para los seres que somos.

(Butler, 2001: 12)

Al centrarse en el proceso de constitución subjetiva por medio de la interpelación ideológica, Butler advierte que esta descripción omite la dependencia fundamental que el individuo- sujeto tiene desde temprana edad con ciertos objetos de amor, estableciendo vínculos apasionados. Este sometimiento primario sería asumido por el propio sujeto consciente de que es una condición para existir. Desde esas coordenadas, Butler realiza una lectura crítica de la propuesta de Althusser de la interpelación ideológica como mecanismo de subjetivación y señala que este evoca implícitamente una adhesión subjetiva que ubica en el gesto de darse vuelta $[\text { turn }]^{98}$, entendido como un giro tropológico.

En la dirección trazada por Butler, el poder opera de manera que el sujeto al darse "vuelta", internaliza las normas vigentes como condición misma de su

\footnotetext{
${ }^{97}$ Butler señala que, para Foucault, por lo menos en Vigilar y castigar, la sujeción no es sólo una subjetivación, sino también "un afianzamiento y un mantenimiento, una instalación del sujeto, una subjetivación" (Butler, 2001: 103). Partiendo de la idea de que, el alma se convierte en un ideal normativo y normalizador conforme al cual, "el cuerpo es adiestrado, moldeado, cultivado e investido: es un ideal imaginario (idéal speculatif) históricamente específico conforme al cual se materializa el cuerpo" (Ídem).

${ }_{98}$ Para Butler, "darse vuelta" es especular tanto en un sentido retórico y performativo. Por lo que es significativo que la autora enfatice que "vuelta" deriva de la palabra griega tropos, que en koiné sería el correlativo a "forma" o "manera, mientras que, en latín clásico tropus significa metáfora o figura retórica (Cfr. Butler, 2001: 13).
} 
conformación, a partir de una identificación con el poder que adopta una forma psíquica:

...la forma que asume el poder está inexorablemente marcada por la figura de darse la vuelta, una vuelta sobre uno/a mismo/a o incluso contra uno/a mismo/a. Esta figura forma parte de la explicación de cómo se produce el sujeto, por cual, en sentido estricto, no existe un sujeto que se dé la vuelta. Por el contrario, la vuelta parece funcionar como inauguración tropológica del sujeto, como momento fundacional cuyo estatuto ontológico será siempre incierto... (Butler, 2001: 13)

Ahora bien, la escena de la interpelación ideológica presentada en Ideología y aparatos...mediante el llamado de la voz policial, presupone -según Butler- no sólo que ya se ha producido la inculcación de la conciencia; sino que esta constituye, además "una operación específicamente psíquica y social del poder" (Ibíd.: 16). En este sentido, mediante el giro físico que realiza el individuo, responde satisfactoriamente a la interpelación ideológica bajo la convicción mental del reconocimiento; que permite que el interpelado esté seguro de que era a él a quien se dirigía precisamente la interpelación ideológica.

Pero Butler insiste: “¿Por qué ese sujeto se vuelve hacia la voz de la ley y cuál es el 'efecto' de semejante 'giro en la inauguración de un sujeto social?” (Ídem). Althusser no ofrece, según la filósofa feminista, las razones que llevan al individuo a responder al llamado de la interpelación ideológica. Althusser, señala Butler, no da ningún indicio de por qué se da vuelta el individuo, "aceptando así que la voz se dirige a él o a ella y aceptando la subordinación y normalización que impone" (Ídem.). Lo que argumenta Butler es que, explicar la constitución subjetiva mediante la escena tropológica de la interpelación, implica suponer a alguien que se dará vuelta y que es inmanente a ese giro. Por otra parte, puesto que los individuos adquieren inteligibilidad al devenir sujetos, es paradójico -según Butler- que Althusser se proponga considerar a los individuos como término inteligible. Lo cual implica una circularidad. En los propios términos de la autora:

El relato de la sujeción es inevitablemente circular, puesto que presupone al mismo sujeto del que pretende dar cuenta. Por un lado, el sujeto sólo puede referirse a su propia génesis 
adoptando una perspectiva de tercera persona con respecto a sí mismo, es decir, desposeyéndose de su propia perspectiva al narrar su génesis. Por otro lado, la narración de la constitución del sujeto presupone que dicha constitución ya ha tenido lugar, $\mathrm{y}$, por tanto, se produce a posteriori.

(Butler, 2001: 22)

Efectivamente, para Butler la doble naturaleza de la sujeción parece conducir a un círculo vicioso que consiste en que la propia potencia del sujeto es al mismo tiempo efecto de su subordinación, y pregunta retóricamente: “¿Cómo es posible que el sujeto, al cual se considera condición e instrumento de la potencia, sea al mismo tiempo efecto de la subordinación, entendida esta como privación de la potencia?" (Ídem).

De acuerdo con la perspectiva de Butler, aunque se trate de un poder que es ejercido sobre el sujeto, el sometimiento es al mismo tiempo un poder asumido por el sujeto, y esa asunción constituye el instrumento de su devenir. En esta línea, si la sujeción es circular, cualquier intento de oponerse y resistirse a la subordinación, necesariamente la presupone y la vuelve a invocar. A diferencia de Zizek que sostiene que hay un "resto" que permanece intacto, un fragmento de sujeto que es también un "vacío" que escapa al orden simbólico y a la interpelación; para Butler, no hay un aspecto resguardado del mundo exterior, y que resista a la simbolización. Sostener este núcleo que resiste a la simbolización, es para Butler, reinstaurar el dualismo interior/exterior. Tal como da cuenta la siguiente cita:

En el mismo acto por el cual reproduce las condiciones de su subordinación, el sujeto ejemplifica la vulnerabilidad temporal inherente a ellas, concretamente, a las exigencias de su renovación. El poder que es condición del sujeto es por fuerza distinto del poder que se dice que ejerce el sujeto. El poder que da origen al sujeto no mantiene una relación de continuidad con el poder que constituye su potencia; cuando el poder modifica su estatuto, pasando de ser condición de la potencia a convertirse en la 'propia' potencia del sujeto (constituyendo una apariencia del poder en la que el sujeto aparece como condición de su 'propio' poder), se produce una inversión significativa y potencialmente habilitante...

(Butler, 2001: 23)

Efectivamente, para Butler, si bien el poder conforma al sujeto, lo hace girando sobre sí tropológicamente; y en ese mismo movimiento, se constituye también un sujeto agente, con potencia de resistir a ese poder y de transformarlo por efecto del propio giro trópico. Para argumentar esto Butler sigue a Nietzsche, para quien el sujeto es formado 
por una voluntad que se vuelve sobre sí misma, adoptando una forma reflexiva; entonces el sujeto "sería la modalidad del poder que se vuelve contra sí mismo" (Ibíd.: 17).

En este marco, las relaciones sociales que sostienen la sujeción, constituyen asimismo la condición de posibilidad de transformación de las mismas, por una vuelta sobre sí mismas de esas relaciones de poder que se internalizan y que posibilitan la agencia del individuo- sujeto que "sería el efecto del poder en repliegue" (Ídem). Butler pretende subvertir así, el sentido de la sujeción como mera reproducción del poder de las clases dominantes, para dar lugar a la resistencia y la agencia. Puesto que, en su propuesta, la emergencia del sujeto implica no sólo su sometimiento a través de los vínculos apasionados, sino que, además “el 'yo' se ve amenazado en lo esencial por el fantasma de la reaparición de ese amor (imposible) y condenado a reescenificarlo en el inconsciente, reviviendo y desplazando una y otra vez el escándalo y la imposibilidad que representa, instrumentando la amenaza que supone para el propio sentido del "yo"” (Butler, 2001: 19).

Para Butler, hay determinantes apasionados y afectivos que explican el consentimiento a la sujeción. En este sentido argumenta que el apego al sometimiento es producto de los manejos del poder, y que el funcionamiento del poder se transparenta parcialmente en ese efecto psíquico. En el marco de su propuesta, "ningún sujeto emerge sin un vínculo apasionado con aquellos de quienes depende de manera esencial (aún si dicha pasión es negativa en sentido psicoanalítico). La situación de dependencia primaria es la que condiciona entonces, la formación y regulación política de los sujetos, y se convierte en el instrumento de su sometimiento. De lo cual concluye Butler que, puesto que es imposible que el sujeto se forme sin un vínculo apasionado con aquellos a quienes está subordinado, entonces "la subordinación demuestra ser esencial para el devenir del sujeto" (Ibíd.: 18).

Desde nuestra perspectiva, considerar la determinación primaria de vínculos apasionados, implica reconocer la anterioridad de la estructura psíquica que da lugar a los afectos con la norma que sujetan al sujeto (súbdito). Con lo cual Butler deja de concebir a las relaciones de poder como constituyentes de los sujetos, para pasar a plantear una ontología que los antecede. En otras palabras, al anteponer la escena psíquica sobre cuyo fondo es posible el giro físico, la propuesta de Butler implica abandonar la referencia materialista a las relaciones sociales de producción y al modo de producción que las implica. Así como implica diluir el componente central de la 
lucha de clases que las atraviesa y que da lugar a las diversas posiciones- sujeto.

Argumentaremos en este sentido que la propuesta de Pêcheux en Las verdades evidentes ([1975] 2016) ${ }^{99}$-para quien "la reproducción de las relaciones de producción, al igual que su transformación es un proceso objetivo cuyo misterio hay que develar" (Pêcheux, 2016: 132)- logra eludir el problema que encontramos en la propuesta de Butler. Asimismo, y en relación con lo anterior, argumentamos que es la tesis de Ideología... "la ideología interpela a los individuos como sujetos" la que "devela el misterio" en cuestión, planteando la cuestión de la constitución de subjetividades en el marco de una teoría materialista de los procesos discursivos, articulada con la problemática de las condiciones ideológicas de reproducción/ transformación de las relaciones de producción. A continuación, daremos un rodeo por la perspectiva crítica de Pêcheux, que constituye -según nuestra perspectiva- una alternativa frente a los problemas planteados.

\section{Pêcheux y su lectura de los sujetos siempre ya hablados}

\section{Cada sujeto es sujetado en el universal como singular 'irreemplazable'}

(Pêcheux, las verdades evidentes)

Para Pêcheux, la respuesta, al porqué del sujetamiento, involucra la articulación entre la estructura ideológica y la estructura del inconsciente desde la dimensión discursiva que adquiere en Ideología y aparatos... la forma de una "ausencia profunda"; pero que como veremos, supo ser el centro del tratamiento que Althusser realizara unos años antes en Las tres notas... La característica común, según Pêcheux, de estas estructuras (la del inconsciente y la de la ideología) es que ocultan su propia existencia dentro de su funcionamiento produciendo una red de verdades evidentes subjetivas “donde subjetivas significa no 'que afectan al sujeto', sino en las que el sujeto se constituye" (Pêcheux, 2016: 136). Lo que ilustra con el pasaje célebre de Ideología y aparatos: "tanto para ustedes como para mí, la categoría de sujeto es una 'evidencia' primera (las evidencias son siempre primeras): está claro que ustedes y yo somos sujetos (libres, morales, etc.)" (Cfr. IAEI: 53).

Ahora bien, Pêcheux lee sintomáticamente que en Ideología... la evidencia de la existencia espontánea del sujeto sea comparada con la evidencia del significado (una

\footnotetext{
${ }^{99}$ Titulado por Michel Pêcheux como Les Vérités de La Palice. Linguistique, sémantique, philosophie. Apareció en 1975 en la colección "Théorie" dirigida por Louis Althusser, de quien Pêcheux fue discípulo.
} 
evidencia expandida en la filosofía del lenguaje idealista, como advierte el autor). Tal como da cuenta la siguiente cita del ensayo de 1970: "Como todas las evidencias, incluso aquellas por las cuales una palabra "designa una cosa" o "posee una significación" (incluyendo, por lo tanto, las evidencias de la transparencia del lenguaje), esta evidencia de que ustedes y yo somos sujetos $-\mathrm{y}$ de que esto no constituye un problema- es un efecto ideológico, el efecto ideológico elemental” (IAEI: 53).

Pêcheux advierte que la evidencia de "que somos sujetos" oculta algo "que se le escapa a Russell y al empirismo lógico" (...) que puede ser ilustrado "con la orden absurda que los niños se dirigen unos a otros como un chiste soberbio: ¡Señor Fulano de Tal, recuérdeme su nombre!, orden cuyo carácter lúdico enmascara su afinidad con la operación policial de asignar y verificar identidades" (Pêcheux, 2016: 137).

De este modo, para Pêcheux, la cuestión de la constitución del sentido se imbrica con la de la constitución del sujeto -no de manera lateral sino "dentro de la tesis central misma, en la figura de la interpelación"100 (Ídem). Esta figura tiene para Pêcheux, en virtud del doble sentido del término interpelación -palabra proveniente del latín- con dos acepciones: 1) la interrupción un discurso; 2) el llamado de los $\mathrm{AIE}^{101}$; el de volver tangible tanto el lazo superestructural entre el ARE y los AIE, y el sujeto ideológico “aquél que dice hablando de sí mismo ¡soy yo!” (Ibíd.: 137).

Asimismo, el mérito de la figura de la interpelación ideológica consiste, según Pêcheux, en que ese "teatro de la conciencia" es observado desde detrás de escena, “desde el revés de su decorado, allí desde donde se puede captar que se habla del sujeto y que se habla al sujeto, antes de que el sujeto pueda decir "hablo"” (Ibíd.: 138). Y, además, se trata de una escena que designa mediante el desfasaje entre individuo/ sujeto que "un no- sujeto es interpelado- constituido en sujeto por la Ideología" (Ídem); distinción donde se ubica según Pêcheux, el efecto retroactivo de la ideología, por el cual los individuos ya siempre son sujetos. Este efecto retroactivo funciona mediante la “evidencia del sujeto como único, irreemplazable e idéntico a sí mismo" (Ídem) ocultando el hecho de que el sujeto es desde siempre ya sujeto ("individuo interpelado en sujeto").

\footnotetext{
${ }^{100}$ Pêcheux enfatiza el uso del término 'figura' para referir a la interpelación, considerando que -como argumenta el propio Althusser- se trata de una 'ilustración', de un ejemplo sometido a un modo de exposición particular.

${ }^{101}$ Para ampliar sobre esta doble acepción: Aguilar Rivero, 1984: 73.
} 
Efectivamente, para Pêcheux la evidencia ideológica de ser sujeto -único, irreemplazable e idéntico a sí mismo- que se expresa en la respuesta absurda “¡soy yo! ante la pregunta "¿quién es?, cuando es "evidente” que soy el único que puedo decir “yo" (moi) al hablar de mí mismo. Esta evidencia enmascara, según Pêcheux, el parentesco con la operación policial de distribución- verificación de las identidades, dado que: "la evidencia de la identidad oculta que esta es el resultado de una identificación- interpelación del sujeto cuyo origen extraño le resulta 'extrañamente familiar"” (Ibíd.: 139).

Pêcheux vincula esta mezcla de absurdo y evidencia con el efecto de preconstruido definido como "la modalidad discursiva del desfasaje en virtud del cual el individuo es interpelado como sujeto...siendo al mismo tiempo "siempre ya sujeto"" (Ídem). Lo cual lo lleva a postular la existencia de un proceso significante en la interpelación- identificación. Entendiendo al significante como lo hace Lacan, como "aquello que representa el sujeto para otro significante" (Ídem).

El efecto de preconstruido consiste en que al estar el sujeto "atrapado" en una red de significantes, se presenta como "causa de sí", como origen de su propio discurso, aludiendo a un efecto fantasmático que Pêcheux ilustra con la figura del Barón de Münchausen, que se levantaba a sí mismo por los pelos. Así, “el ‘sujeto' es interpeladoconstituido en la evidencia de la constatación que vehiculiza y enmascara la norma identificatoria" (Ibíd.: 141) bajo la que, por ejemplo, puesto que "un soldado francés no retrocede", se sigue que este puede o no puede retroceder" (Ídem).

En este marco, ¿cómo internaliza el individuo-sujeto la norma? Pêcheux afirma que es a través de la costumbre y del uso de ciertos significantes que la ideología designa al mismo tiempo lo que es y lo que debe ser, "a veces con desviaciones lingüísticamente marcadas entre la constatación y la norma, las que funcionan como un dispositivo de reajuste" (Ibíd.: 141-142). Es ella (la ideología) la que provee las evidencias por las cuales cada uno sabe lo que es, enmascarando en la "transparencia del lenguaje", el carácter material del sentido de las palabras y de los enunciados.

Ahora bien, Pêcheux subraya la referencia a la evidencia del sentido incluida en el comentario de la evidencia de ser sujeto en Ideología y aparatos...(“como todas las evidencias" ...) y le da centralidad a una sentencia que Althusser coloca de manera marginal, en nota al pie, que dice así: "los lingüistas y los que se refugian en la lingüística con fines diversos tropiezan a menudo con dificultades que resultan de su desconocimiento, del juego de los efectos ideológicos en todos los discursos, incluso los 
discursos científicos" (IAEI: 53). Pêcheux argumenta, en esta dirección, que el carácter material del sentido, enmascarado por su evidencia transparente para el sujeto, reside en su dependencia constitutiva de las formaciones ideológicas, y lo presenta bajo dos tesis: a) el sentido de una palabra, de una expresión, de una proposición, etc. cambia de sentido según las posiciones que ocupan los que las emplean "lo que significa que adquieren su sentido en referencia a las formaciones ideológicas en la que estas posiciones se inscriben" (Pêcheux, 2016: 142). De allí que, una palabra, una expresión o una proposición no tengan un sentido propio ligado a su literalidad, sino que su sentido se constituye en cada formación discursiva, en las relaciones que las palabras tienen con otras palabras (Ibíd.: 143). Una formación discursiva es aquello que, a partir de una posición dada en una coyuntura dada determinada por la lucha de clases, "determina lo que puede y debe ser dicho" (Ibíd.: 142).

Esta conclusión se articula inmediatamente con la segunda tesis: b) "toda formación discursiva disimula, en virtud de la transparencia del sentido que en ella se constituye, su dependencia respecto del todo complejo con dominante de las formaciones discursivas, intrincado en el complejo de las formaciones ideológicas" (Ibíd.: 144). Lo propio de toda formación discursiva es, en este marco, disimular "en la transparencia del sentido que en ella se forma, la objetividad material contradictoria del interdiscurso" (ídem), que habla antes en otra parte. Y que se conecta profundamente con el efecto del preconstruido, y con el de articulación, que están determinados materialmente en la propia estructura del interdiscurso. Por ello para Pêcheux:

los individuos son interpelados como sujetos hablantes (como sujetos de su discurso) por las formaciones discursivas que representan "en el lenguaje" las formaciones ideológicas que les corresponden", y precisábamos que "la interpelación del individuo en sujeto de su discurso se efectúa mediante la identificación (del sujeto) con la formación discursiva que

lo domina.

(Pêcheux, 2016: 186)

Desde nuestra perspectiva, evaluamos que, el hecho de que las formaciones discursivas sean móviles, políticas y el resultado de la lucha de clases, desestabiliza las críticas funcionalistas, puesto que, como señalara Althusser en una de las partes suprimidas de Sobre la reproducción: "la primacía de la lucha de clases es incompatible con todo funcionalismo" (SR: 257). Es esta misma estrategia la que Althusser ha 
utilizado al destacar que la burguesía francesa solo pudo mantener su dominio después del periodo revolucionario "pagando el precio de una lucha de clases muy larga y muy dura" (IF: 143). E insiste en la relación orgánica que existe entre el dominio a través de la fuerza, y del consentimiento al mismo tiempo que:

Es como si la clase que se ha apropiado del poder del Estado y se vuelve dominante tuviera necesidad, además de usar los aparatos represores del Estado (el ejército, la policía, los tribunales), que funcionan ante todo ejerciendo violencia física, de usar otro tipo de aparatos, que funcionan ante todo 'mediante la ideología', es decir, mediante la persuasión. No se trata de una fantasía, de un lujo de la clase dominante que querría dominar no solo por la fuerza, sino también por el lujo de un suplemento gratuito: la persuasión, el consenso, el consentimiento.

(IF: 144).

Efectivamente, frente a las críticas de que la interpelación ideológica es única y acabada, el carácter central de la lucha de clases habilita la posibilidad de identificarse con ideas, valores y normas contrahegemónicos, así como de desidentificarse y contraidentificarse.

\section{La primacía de la lucha de clases en los AIE}

¿Por qué la filosofia pelea por palabras? [...] en la lucha politica, ideológica y filosófica las palabras son también armas: explosivos, calmantes o venenos. Toda la lucha de clases puede, a veces, resumirse en la lucha por una palabra, contra otra palabra. Ciertas palabras luchan entre ellas como enemigos. Otras dan lugar a equívocos, a una batalla decisiva pero indecisa. [...] contra las palabras-mentira, contra las palabras-equivocos; por las palabras justas. Combate por "matices". (Louis Althusser, La filosofía: arma de la revolución)

En primer lugar, comenzaremos señalando que la sección "El Estado y sus aparatos" de Sobre la reproducción es alterada y muchas partes suprimidas en la versión de "El Estado" de Ideología y aparatos... Esto es lo que ocurre con el capítulo "Reproducción de las relaciones de producción y revolución” y la sección sobre "Los aparatos ideológicos del Estado y los sub- productos (sous- produits) ideológicos y sus prácticas". En esas partes Althusser afirma que es la lucha de clases "presente desde el principio" la que es constitutiva de los aparatos mismos, que emergerían como respuesta a movimientos ya existentes de resistencia a la reproducción de las relaciones de 
producción. Es por ello que para Montag, "la lucha de clases deforma a los aparatos, no solamente inhibiendo su funcionamiento sino causándoles la producción de efectos contradictorios" (Montag, 2014: 66).

Enfatizando el componente disruptivo de los AIE en ;Osar pensar es osar revelarse! (2014) ${ }^{102}$ Pêcheux señala que los AIE no son puros instrumentos de la clase dominante, máquinas ideológicas que reproducen pura y simplemente las relaciones de producción existentes, sino que de manera simultánea y contradictoria ocupan "el lugar de las condiciones ideológicas de la transformación de las relaciones de producción (es decir, de la revolución, en un sentido marxista-leninista)" (Pêcheux, 2014: 4). Pêcheux lee que los aparatos en la propuesta althusseriana, tienen un doble funcionamiento, además de tendencia a producir conflicto en lugar de orden. Esta potencialidad de desestabilizar las relaciones de clase que tienen los AIE es constitutiva de estos ya que se encuentran regidos por la lucha de clases "que los atraviesa desde el principio"103.

Ahora bien, aunque la supresión de ciertas partes de Sobre la reproducción en la versión más breve de Ideología y aparatos... ha suscitado interpretaciones funcionalistas y reproductivistas, es fundamental atender a aquello que destaca Pêcheux: que en este ensayo la primacía de la lucha de clases se encuentra en la distinción que Althusser introduce en el postcriptum entre "Ideología en general"104 e "ideologías particulares" que hemos explorado en el capítulo IV, y que se manifiesta en la siguiente cita de Ideología y aparatos...:

... la lucha de clases en los Aparatos Ideológicos del Estado es, por cierto, un aspecto de la lucha de clases. Pero la lucha de clases en los Aparatos Ideológicos del Estado es sólo un aspecto de una lucha de clases que desborda los Aparatos Ideológicos del Estado. La ideología que una clase en el poder torna dominante en sus Aparatos Ideológicos del Estado se "realiza" efectivamente en esos Aparatos Ideológicos del Estado, pero los desborda porque proviene de otra parte. Del mismo modo, la ideología que una clase dominada logra defender en

${ }^{102}$ N/T: Este texto fue editado en alemán bajo el título: "Zu rebelieren und zu Denken wagen! Ideologien, Wiederstände, Klassenkampf” En KultuRRevolution, 1984, n 5 pp. 61-65 y 1984, n 5, pp. 63-66. En el manuscrito en francés, sobre el título se encuentra otro, escrito a mano y tachado: "Ideología proletaria y teoría marxista en la lucha ideológica de clases."

${ }^{103}$ Hacia el final de esta parte, exploraremos que la propuesta de Pêcheux es una alternativa frente a las críticas funcionalistas al enfatizar el componente conflictivo de los AIE, y que posibilitan pensar la "reproducción- transformación de las relaciones de producción".

104 Pêcheux señala que contrariamente a lo que ocurre en Para una crítica de la práctica teórica, la expresión "Ideología en general" permite pensar al "hombre" no como antinaturaleza, sujeto de la historia, trascendencia, etc. Sino como "animal ideológico" en el sentido spinoziano, esto es, como parte de la naturaleza. 
y contra tales Aparatos Ideológicos del Estado los desborda, porque proviene de otra parte...

(IAEI: 125)

Efectivamente, en el postcriptum Althusser introduce la lucha de clases como elemento que posibilita distinguir entre "Ideología en general" e "ideologías concretas" (o singulares, al decir de Pêcheux). Recordemos lo ya explorado: mientras que las últimas, tendrían una existencia histórica concreta como la religión, la moral, la política, etc. La Ideología en general- ideología a secas- es omnihistórica, "no tiene historia propia" (como el inconsciente, que es eterno ${ }^{105}$ ), sino que es "omnipresente bajo su forma inmutable en toda la historia de las formaciones sociales que incluyen clases sociales (SR: 215) ${ }^{106}$. Lo cual puede ser comparado con la distinción saussureana entre la "lengua" (langue), la estructura abstracta inmaterial del lenguaje y el "habla" (parole), la materialización concreta de esa lengua por cada hablante particular (Saussure, 1996).

Ahora bien, Pêcheux realiza una lectura sintomática sobre la tesis althusseriana de que los sujetos "marchan solos" y ve en esta no sólo la primacía de la lucha de clases, sino también la posibilidad de que se produzcan modalidades de contraidentificación y de desidentificación, además de la identificación, como efectos de la interpelación.

\section{Identificaciones, contraidentificaciones y desidentificaciones}

...toda continuidad estructural es el efecto necesario de una contingencia irreductible en la que, en cada instante, reside la posibilidad latente de una

Pêcheux intenta caracterizar las diferentes modalidades del desdoblamiento del sujeto en un sujeto singular y un Sujeto universal; distinguiendo en la interpelación ideológica los efectos de identificación, de contra- identificación, y de desidentificación. Las diversas modalidades del proceso ideológico quedan así expuestas:

\footnotetext{
${ }^{105}$ Las estructuras- funcionamientos de la ideología y el inconsciente tendrían en común el "disimular su propia existencia en el interior mismo de su funcionamiento produciendo un tejido de evidencias "subjetivas" (en el sentido de que constituyen al sujeto) (Pêcheux, 2016: 136).

${ }^{106}$ Frente a las críticas que señalan que en la pretensión althusseriana de construir una teoría en general que valga para todas las formas ideológicas de clase se dejaría de lado el abordaje de la lucha de clases, cabe responder que el alcance de esta teoría se limita a la sociedad de clases. Que sea omnihistórica no implica que sea omniabarcativa. Lo que sí tiene es carácter inmutable, puesto que es una dimensión necesaria e irreductible de toda formación social (Gillot, 2010).
} 
1. Las identificaciones aquella modalidad en la cual el desdoblamiento sujeto/Sujeto se realiza en una coincidencia: el sujeto coincide con el Sujeto, el individuo interpelado en sujeto se sujeta libremente al Sujeto y "marcha solo".

Lo que sucede, explica Pêcheux siguiendo a Althusser, es que el sujeto reconoce el estado de cosas existentes (das Bestehende) con la convicción de que "son así y no queda otra opción". Pêcheux ejemplifica esta modalidad del desdoblamiento del sujeto con lo ocurrido en la Primera Guerra Mundial, en la que la gran mayoría de los sujetos franceses "marcharon solos" (bajo el discurso de que "Francia está amenazada/ nosotros somos todos franceses/ ¡esto es la guerra!”) reconociendo una cadena de evidencias del orden del hecho consumado, articuladas en diversas constataciones cargadas de evidencias preconstruidas inculcadas desde temprana edad, y que operan como mandatos, como por ejemplo, aquella que sostiene que "Un soldado francés no retrocede”. Así se completa, según Pêcheux la identificación de cada sujeto francés al Sujeto- Francia. (Pêcheux, 2014: 8- 9).

2. La contraidentificación: es la no coincidencia entre sujeto /Sujeto. Siguiendo con el ejemplo de la Primera Guerra Mundial, Pêcheux subraya que la historia nos enseña también que, en ciertas circunstancias, los sujetos no marchan solos. Ya que, bajo el efecto de la lucha de clases se rompe la coincidencia entre sujeto/Sujeto de modo que algunos "malos sujetos" manifestaron una serie de rechazos, inversiones [retournements] y rebeliones [révoltes] que requirieron a veces la intervención de tal o cual destacamento especializado del Aparato Represivo de Estado (la policía militar, por ejemplo).

De esta manera, Pêcheux introduce el término de contra-identificación para caracterizar ese proceso ideológico de no-coincidencia, en el cual las evidencias empíricas singulares (como la republicana- burguesa) se separan de la evidencia universal según la cual "los franceses son iguales ante la guerra". De acuerdo con el análisis de Pêcheux, lo que ocurre es que se da vuelta [retournée] la evidencia "en un funcionamiento espontáneo de la ideología dominada del proletariado obrero y campesino", por otra evidencia: la que "son siempre los mismos los que mueren" (Ibíd.: 10).

3. La des- identificación: es la modalidad de ruptura radical con la identificación. Pêcheux especifica este efecto de ruptura ideológica (distinto de la toma en sentido literal y la inversión [retournement] de la contra-identificación) que forma parte del efecto de la práctica revolucionaria proletaria y de la teoría marxista. 
Esta tercera modalidad ideológica (que no debe ser pensada como una especie de síntesis hegeliana que reconciliaría las modalidades anteriores) denominada desidentificación por Pêcheux, afecta completamente la relación entre sujeto/Sujeto. Y se trata de una transformación radical de la forma-sujeto. Bajo el efecto de este acontecimiento sin precedentes en la historia que constituye la fusión tendencial de prácticas revolucionarias del movimiento obrero con la teoría científica de la lucha de clases" (Ídem.).

Para Pêcheux, el primado práctico de la lucha de clases impone, por lo tanto, rechazar a toda costa una concepción del proceso ideológico de la desidentificación que haga de ella una suerte de trayecto de tipo platónico, un recorrido teórico que pasaría, "a imagen del mito de la Caverna" (Ibíd.: 11) por tres momentos:

1. El mecanismo ideológico de la interpelación-sujeción;

2. El borramiento ("olvido") de toda marca reconocible de este mecanismo.

3. el dominio teórico de dicho mecanismo, conquistado por rememoración a través de una suerte de anamnesis (del griego $\alpha v \alpha \mu \nu \eta \sigma ı$, , recolección, reminiscencia) con el aspecto práctico del marxismo leninismo.

Pêcheux explora la concepción pedagógica de la lucha ideológica como constitutiva de un efecto de retorno de la ideología burguesa al interior mismo de las ideologías del movimiento obrero. "Bajo esta doble figura auto- o hétero pedagógica, la historia del movimiento obrero y de la práctica proletaria toman la forma de un trayecto que uniría un punto de partida (las ideologías dominadas del modo de producción capitalista) y un punto de llegada u objetivo estratégico" (Ibíd.: 12).

Para Pêcheux, la repetición ideológica del trayecto en el lugar marca el punto donde la ideología dominante burguesa, asegura desde adentro, su dominio sobre las luchas del movimiento obrero a través de diferentes formas, como la "del vacío de toda ideología dominada" que intenta convencer de que no hay nada exterior al poder del Amo, y que, por lo tanto, es imposible rebelarse; y la forma de "la repetición del mundo del Amo en un segundo mundo, subordinado, devaluado y folclórico" (Ibíd.: 13).

Por todo lo expuesto, Pêcheux concluye que la tesis de que "los sujetos marchan solos" refuerza la primacía de la lucha de clases desatada por las clases dominadas 
contra la dominación ${ }^{107}$, una lucha que no tiene comienzo ni fin asignable (ME: 33) y que posibilita la transformación de las relaciones de producción que los someten.

\section{La reproducción/ transformación de las relaciones de producción}

...la interpelación es el terreno de la producción del discurso, y de que a los efectos de "producir" sujetos de modo exitoso estos últimos deben identificarse con la interpelación. El énfasis althusseriano en la interpelación como mecanismo funcional de la reproducción social no deja suficiente espacio para estudiar la construcción de sujetos desde la perspectiva de los individuos que reciben estas interpelaciones.

(Laclau, Nuevas reflexiones sobre la revolución de nuestro tiempo)

Para Pêcheux, comprender la interpelación ideológica althusseriana como ritual implica reconocer que no hay ritual sin falla, con lo cual la apertura a lo contingente, al acto fallido y a los lapsus, son siempre una posibilidad. Decir "una palabra por otra" es la definición de la metáfora, pero es también - según Pêcheux- el punto en el cual un ritual ideológico llega a romperse en el lapsus (los ejemplos no faltan en la ceremonia religiosa, el procedimiento jurídico, la lección pedagógica o el discurso político).

En este sentido, "el lapsus y el acto fallido marcan lo imposible de una dominación ideológica fuera de toda contradicción” (Pêcheux, 2014: 17). Existen toda una serie de efectos dados por los lapsus y el acto fallido que infectan a toda ideología dominante, afirma Pêcheux: "desde el interior mismo de las prácticas donde ella tiende a realizarse; los juramentos y las blasfemias de todo tipo que vienen a la boca de los creyentes, sin que ellos se den cuenta y contra su voluntad, los incidentes que ocurren en un ritual en el momento más inesperado" (ídem).

Efectivamente, la posibilidad de fallar del ritual, a través de los equívocos de los enrolados, los creyentes y los dominados, tiene que ver para Pêcheux con el origen imaginario, vivido de la resistencia y la rebelión. Puesto que, las ideologías dominadas se forman precisamente en "el emplazamiento mismo de la dominación, en ella y contra ella, a través de las fallas y de los obstáculos que la afectan inevitablemente, mismo cuando la dominación se extiende a punto tal que 'ahí no hay nada que hacer' porque "esto es así"” (Ídem). Constituyendo un resto que puede retornar de forma imprevisible fallando la interpelación. En este sentido, Pêcheux apuesta a:

${ }^{107}$ En términos de Kójeve, el sujeto de la historia es el proletariado, puesto que no busca librar esta batalla para convertirse él mismo en amo explotador, sino que lo que busca es abolir las relaciones mismas de dominación. 
reconstituir las formas fugitivas de aparición de algo "de otro orden", victorias ínfimas que, rápidas como un rayo, ponen en jaque a la ideología dominante sacando provecho de su tropiezo, por lo tanto reconstituir el éxito del lapsus, del acto "fallido", del equívoco y de

la ambivalencia en las fallas de la interpelación, del ritual, del orden ideológico, no supone hacer de ahora en más del inconsciente la fuente de las ideologías dominadas, luego de haber renunciado a convertirlo en el resorte superyoico de la ideología dominante. El orden del inconsciente no coincide con el de la ideología, la represión [réfoulement] no se identifica con la sujeción, ni con la supresión [répression], pero la ideología no puede pensarse sin referencia al registro inconsciente. El lapsus, el acto fallido, etc. constituyen, en tanto que astillas y escombros de rituales, las materias primas de la lucha ideológica de las clases dominadas, en la misma medida en que el círculo-ritual de la interpelación ideológica es la materia prima de la dominación ideológica"

(Pêcheux, 2014: 17)

Hemos anticipado que la expresión "reproducción/ transformación de las relaciones de producción" es introducida por Pêcheux con el objetivo de descubrir los fundamentos de una teoría materialista del discurso. Y se caracteriza por el carácter "nodalmente contradictorio de todo modo de producción basado en la división de clases, es decir, cuyo ‘principio' es la lucha de clases” (Pêcheux, 2016: 129).

La lucha de clases atraviesa el modo de producción en su conjunto, lo cual significa, para decirlo en los términos que lo hace Pêcheux, que, en el ámbito de la ideología, "la lucha de clases 'pasa a través de' lo que Althusser llamó aparatos ideológicos del Estado" (ídem) término con el que se quiere destacar además de la cuestión que parece obvia: que las ideologías no están hechas de ideas sino de prácticas:

1) la ideología no se reproduce bajo la forma general de un Zeigest: es decir como "espíritu de una época" que se impondría de manera homogénea en una sociedad: "los AIE no son la realización de la ideología en general".

2) los AIE no son la realización sin conflictos de la ideología de la clase dominante, lo cual equivaldría, según Pêcheux, a atribuir a cada clase su ideología, como si cada una viviera "antes de la lucha de clases".

3) los AIE no son la expresión de la dominación de la ideología dominante, es decir, de la ideología de la clase dominante; sino que "la ideología de la clase dominante es realizada y se realiza y se convierte en dominante con la puesta en marcha de los AIE" (Ibíd.: 130). 
4) los AIE no son puros instrumentos de la clase dominante, máquinas ideológicas que reproducen pura y simplemente las relaciones de producción existentes, sino que la puesta en marcha de los AIE es objeto de una "ininterrumpida y muy dura lucha de clases". De allí que para Pêcheux "los AIE constituyen simultánea y contradictoriamente el lugar y las condiciones ideológicas de la transformación de las relaciones de producción (de la revolución en el sentido marxista leninista)" (Ídem).

Siguiendo por esta línea que destaca el componente inherentemente contradictorio de los aparatos de Estado, Pêcheux señala que, en su materialidad concreta, la instancia ideológica existe en las "formaciones ideológicas" 108 (referidas a los aparatos ideológicos del Estado), que a la vez poseen un carácter regional y comportan posiciones de clase ${ }^{109}$. Cabe aclarar que las "posiciones de clase" no deben pensarse como la "ideología de un grupo social particular" o como la "conciencia de clase”. En este sentido, Pêcheux señala el primado de dos tesis que impiden caer en esos equívocos:

1) la primera es que si se toma en serio la referencia al materialismo histórico significa reconocer el primado de la lucha de clases por sobre la existencia de las clases en sí mismas. De manera que se obturen los análisis de naturaleza sociológica o psicológica en términos diferenciales de clase, según los cuales a cada grupo social se le podría atribuir una ideología con anterioridad a que las ideologías entren en conflicto.

En este sentido, Pêcheux interroga la noción de ideología dominada -“a menudo identificada con un segundo mundo subterráneo, reflejo difuso, imperfecto $\mathrm{y}$ caricaturesco del primero" (2014: 2)- para determinar sus características bajo el primado de la lucha de clases.

2) para Pêcheux, tomar en serio la referencia al concepto psicoanalítico de inconsciente, implica reconocer el primado de este sobre la conciencia, lo que en términos de ideología se traduce en rechazar toda concepción psicologista que ponga en escena una conciencia, incluso de clase, que "se abriría camino ella misma por autoexplicitación, hacia su propia transparencia..." (Ídem.).

En este sentido, contra quienes han leído un reproductivismo en Ideología y

\footnotetext{
108 Pêcheux opta por utilizar el concepto de formaciones ideológicas en lugar de ideología, que es un concepto que "tiene a la mano" Althusser.

109 "No hay en la lucha ideológica (así como tampoco en las otras formas de las luchas de clases) 'posiciones de clase abstractamente existentes que se aplicarían luego a los diferentes 'objetos' (...) es el recorte mismo en regiones (Dios, la Moral, la Ley, la Justicia, la Familia, el Saber, etc.) y las relaciones de desigualdad-subordinación entre estas regiones los que constituyen el objeto de la lucha ideológica de clases" (Pêcheux, 2016: 131).
} 
aparatos...Pêcheux destaca la primacía de la lucha de clases, como aquella que tiene como resultado la constitución de una clase dominante y una clase dominada. En este marco, la ideología dominante es la ideología de la clase dominante, es decir, de aquella clase que resultó dominante en el proceso de lucha. Mientras que, la clase dominada, resultó subordinada. Por ello es que esta ideología dominante es constitutivamente contradictoria y compleja.

Esta cuestión es planteada por Althusser cuando afirma que la ideología dominante es realizada como "efecto de una ininterrumpida y muy dura lucha de clases, primero contra las antiguas clases dominantes y sus posiciones en los viejos y nuevos AIE, después contra la clase explotada" (IAEI: 83). La existencia de ideologías dominadas, muestra para Althusser que, "en el interior de la ideología en general, se observa la existencia de tendencias ideológicas diferentes, que expresan las representaciones de las diferentes clases sociales" (PPT: 54).

Ahora bien, puesto que, cada ideología -aun determinada siempre en última instancia por la lucha de clases- tiene una cierta autonomía relativa; la ideología dominante cumple la función de unificar en una estructura compleja (en sus contradicciones y reacciones de los elementos entre sí) la diversidad de las formaciones ideológicas. Esta unidad compleja de las formaciones ideológicas, revela la autonomía relativa de la ideología respecto de la ciencia en cuanto a su eficacia social transformadora. Reconociendo así, el espacio para la lucha ideológica en el marco de la ideología teórica y la práctica materializada en los AIE.

Pêcheux señala en ese sentido que las formaciones ideológicas tienen carácter regional: cada uno de los elementos que componen una multiplicidad diferenciada de la instancia ideológica en la forma de una combinación en la totalidad compleja, es una formación social. En este sentido, la estructura de desigualdad- subordinación de la totalidad compleja "en dominación de las formaciones ideológicas de una formación social dada" caracteriza la objetividad material de la instancia ideológica. Con lo cual se trata de una estructura que no es otra cosa que "la de la contradicción entre reproducción y transformación que constituye la lucha de clases" (Pêcheux, 2016: 129130). A su vez, esta lucha ideológica entre dos clases antagónicas no es simétrica en el sentido de que cada clase trate de alcanzar lo mismo que la otra.

Pêcheux enfatiza que, la relación de clase se oculta en la operación del aparato del Estado por el mismo mecanismo que la realiza, según el cual la sociedad, el Estado, y los sujetos de la ley ("libres e iguales en principio, en el modo de producción 
capitalista) son producidos- reproducidos como "nociones naturalmente evidentes" (SR: 161). Y concluye que "la reproducción, tanto como la transformación de las relaciones de producción es un proceso objetivo cuyo misterio debe ser comprendido" (Pêcheux, 2016: 133).

Entonces bien, la materialidad de la lucha de clases, vertebral y transversal en la intervención materialista althusseriana en la que se destaca el carácter sobredeterminado de la estructura de las formaciones sociales, permite eludir el funcionalismo que se le ha atribuido a la propuesta de Althusser. Este materialismo sobredeterminado retoma: 1) el materialismo de Spinoza, para quien el cuerpo humano se compone de muchos otros, de diversa naturaleza; 2) a Marx, cuya dialéctica es contradictoria, desigual y sobredeterminada; y 3) lo iniciado por Freud para quien, el psiquismo también es una estructura compleja y dinámica de diversas instancias en la que intervienen pulsiones e impulsos primarios. Dando lugar a plantear interpelaciones diversas, además de identificaciones fallidas, y resistencias.

\section{"Sujetos" interpelados por los afectos}

Tales mutaciones de la subjetividad no funcionan sólo en el registro de las ideologías, sino en el propio corazón de los individuos, en su manera de percibir el mundo, de articularse con el tejido urbano, con los procesos maquínicos del trabajo y con el orden social que soporta esas fuerzas productivas... (Guattari y Rolnik. Micropolítica. Cartografias del deseo)

El hecho de que Althusser afirme en su intervención materialista que "la totalidad está sobredeterminada" implica que las múltiples oposiciones y contradicciones interiores a una formación social dada no funcionan en un solo sentido, aunque están sometidas a "leyes tendenciales" que implican un predominio de las relaciones de clases existentes ${ }^{110}$. Por lo tanto, se pueden suscitar múltiples interpelaciones, identificaciones fallidas, resistencias. Esta cuestión es sugerida por Althusser cuando postula que existen, -aunque de forma minoritaria- "los malos sujetos"; aquellos en los que las prácticas ideológicas no han sido efectivas, ya que no

\footnotetext{
${ }^{110}$ Gabriela Mainini (2015) explorando Ideología y aparatos... sostiene que no toda ideología sujeta al individuo al Estado. No hay, desde su perspectiva, un sometimiento totalitario que lleva a una servidumbre voluntaria y libre de los individuos en la reproducción de las relaciones de producción. La sujeción sobre los individuos actúa en el plano de su reconocimiento a una determinada ideología y por esta razón puede ser la contrapartida de iniciativas emancipadoras, ya que las relaciones ideológicas a las que se sujetan los individuos no siempre coincidirán con las de la clase dominante.
} 
se han identificado con la ideología dominante. Sin embargo, Althusser no desarrolla ni explica cómo se constituyen estos ${ }^{111}$, lo cual leemos sintomáticamente.

Lo que, sin embargo, puede ser desarrollado y ampliado atendiendo a la distinción entre Ideología en general e ideologías concretas por efecto de la lucha de clases que atraviesa a los AIE. Los que, por la misma razón, no son monolíticos, sino que proyectan múltiples signos. Por tanto, aunque haya una ideología dominante, esto no implica que sólo exista esta ideología, sino que se encuentran en conflicto ${ }^{112}$, puesto que "la ideología dominante no domina jamás sin contradicciones" (Pêcheux, 2015: 15).

Es esta posibilidad de subversión, de resistencia y de agencia frente al dominio ideológico como intrínseco a las sociedades capitalistas la que explora Frederick Lordon ([2010] (2015) atendiendo al lugar central de las contradicciones y el conflicto como inmanentes a la dominación misma. Para Lordon, sostener la primacía de la causalidad inmanente, implica sostener también que los efectos de la estructura económica sobre la estructura de la ideología, deben ser pensados simultáneamente, como causas y como efectos, como condiciones mismas de su reproducción.

En esta dirección, Lordon destaca que no sólo vivimos en una economía capitalista, sino también en una sociedad capitalista. Esta consideración apunta a señalar que el capital no puede ser comprendido simplemente en términos de economía, sino que debe ser entendido como lo inmanente a sus efectos. Es en este sentido que la lectura de Spinoza y de Marx por Lordon detecta una cuestión central: el capital direcciona también nuestros deseos. Tal como da cuenta la siguiente cita,

Lo propio de la dominación consiste en fijar a los dominados a objetos de deseo menores -en todo caso, juzgados tales por los dominantes, que se reservan los otros. En la alegría antes que, en el temor, he allí indudablemente la manera en que los dominantes gobernarán más eficazmente, pero circunscribiendo estrictamente las alegrías ofrecidas, es decir, seleccionando rigurosamente los objetos de deseo propuestos.

\footnotetext{
111 Aguilar Rivero expone como representante de estos malos sujetos a Antígona y el conflicto que ella personifica entre la obediencia a la ley divina y el sometimiento a la ley estatal: si Antígona puede llevar a cabo un quiebre tan radical con las leyes existentes de su grupo social, es porque primero ha podido liberarse de los llamados de la interpelación social.

112 Estas tensiones y conflictos toman una forma precisa cuando Althusser pide disculpas a los maestros que "en condiciones espantosas intentan volver contra la ideología, contra el sistema, y contra las prácticas de que son prisioneros, las pocas armas que pueden hallar en la historia, y el saber que ellos 'enseñan'. Son una especie de héroes, pero no abundan" (IAEI: 38). Sin embargo, Althusser insiste en que, aun con intenciones revolucionarias, estos maestros, ni sospechan que "contribuyen a mantener y a alimentar esta representación ideológica de la escuela, que la hace tan 'natural' e indispensable" (Ídem).
} 
Regular la distribución de lo deseable podría ser entonces el efecto más característico de la dominación, y también el más general, puesto que el espectro de lo deseable se extiende desde el deseo de evitar un mal hasta el deseo de conquistar los bienes mayores (los bienes socialmente considerados mayores), pasando por lo deseos de objetos menores, fuente de pequeñas alegrías reservadas para la gente inferior (...)

(Lordon, 2015: 125)

Que la ideología sea también la pre-condición del modo de producción, no sólo su efecto, significa que la reproducción de las relaciones de producción corresponde tanto a la reproducción de los deseos como a la ideología o a la imaginación. En términos spinozianos, implica que el conatus sea comprendido como estructurado y como estructurante al mismo tiempo.

De manera análoga, en Los afectos de la política ([2017] 2016) Lordon señala que el neoliberalismo en tanto sistema integral (político, social, cultural, ideológico) tiene como una de sus estrategias predilectas, lograr el ostracismo de los sujetos, abonando el individualismo y el solipsismo, para evitar que haya un registro de "lo social", por ende, que se establezcan lazos sociales solidarios, propios del colectivismo; o de replicar experiencias de sublevación, capaces de subvertir el poder del Estado de las clases dominantes. Por ello para Lordon, el desafío de los análisis centrados en los procesos de subjetivación, entendidos desde su materialidad práctica debe ser el de potenciar los afectos en política, pero demarcándose de la concepción humanista del sujeto como centro, que se articula con las concepciones liberales y cartesianas.

Siguiendo esta dirección, e intentando intervenir en nuestra coyuntura actual nos preguntamos siguiendo a Lordon y su lectura de Marx y Spinoza: ¿cómo se enlaza la alegría ofrecida por los dominantes con la inculcación de un deseo que no libera, sino que sujeta? ¿De qué manera la ideología neoliberal es capaz de direccionar nuestros deseos hacia aquello que nos hace menos libres y que precariza nuestras vidas? ¿Cómo se mueven los cuerpos sujetados hacia esos objetos de deseo?

Lordon señala que la potencia del discurso neoliberal radica precisamente en lograr reinternalizar los objetos de deseo de los enrolados, no sólo hacia la obtención de dinero sino también hacia otras satisfacciones mediante la persuasión de que sus pequeñas alegrías son, en realidad, enormes: “en la alegría antes que, en el temor, he allí indudablemente la manera en que los dominantes gobernarán más eficazmente" (Lordon, 2015: 124). Regular "lo deseable" es entonces, el efecto más característico de 
la dominación que ejerce la forma neoliberal del capitalismo (caracterizado por Lordon, como un proyecto de encantamiento y de disfrute) que se propone enriquecer la relación de afectos alegres, ya no únicamente bajo la especie del deseo de dinero, sino como deseo de otras cosas, "de nuevas satisfacciones transitivas, es decir inherentes a la propia actividad salarial" (Ibíd.: 78).

En este marco de análisis, el poder, en su modo de operar, es considerado como perteneciente al orden de la producción de afectos y de la inducción de afectos (el afecto en términos de Spinoza es lo que una afección -un encuentro de cosa- me hace: producción de alegría o tristeza). Entonces bien, dado que de un afecto resultan una redirección del conatus y el deseo de hacer algo, quien pretenda dominar debe orientar los conatus-vectores de deseo hacia ciertas direcciones que le permitan gobernar. Ergo, el poder es así, “el conjunto de prácticas de colinealización” (Ibíd.: 79).

En este sentido, la conceptualización spinoziana del obsequium, como complejo de afectos que hace que se muevan los cuerpos sujetados hacia los objetos de la norma, y la comprensión del sujeto como subditus- sujeto del soberano- da una clave para comprender el interés que los gobiernos neoliberales ponen en direccionar cada vez más nuestros deseos hacia el consumo, hacia los fines empresariales y los valores morales propuestos por el capital, bajo la ilusión de alcanzar así una felicidad; que no será más que efímera y superficial capaz de "exaltar la expansión y la productividad al mismo tiempo que el Hombre y la libertad". (PPT: 97).

Lo cual -como señala Althusser también contra el humanismo liberal- permite a la pareja economicismo/humanismo, que expresa el punto de vista burgués "trabajar para disimular, asegurar y reproducir las relaciones de explotación” (Ídem) invisibilizando las relaciones de producción y la lucha de clases. Inscribir el problema de la ideología neoliberal en una perspectiva materialista -que en la lectura de Althusser nos remonta a Spinoza- nos permite comprender por qué en el Tratado teológicopolítico su autor afirma que, guiadas por el vulgo, los sujetos le dan el sentido que desean a los textos sagrados; y que potenciados por la imaginación propia de los relatos revelados, caen en la ignorancia de donde derivan conflictos y las luchas religiosas, por las pretensiones de homogeneización y de uniformización tanto por parte de las religiones como de políticas profanas.

Volviendo al análisis de Lordon, este examina que la ideología neoliberal productora de sujetos deseosos de una plenitud (imposible)- promete una sociedad sin fricciones, bajo la que subyace una pretendida realidad homogénea; invisibilizando el 
conflicto y anulando así la alteridad. La cuestión central de este mecanismo ideológico es, según el autor que, mientras, por un lado, ofrece a los sujetos el conocimiento de un proyecto integrador basado en la alegría y en la confianza; por otro lado, hay un desconocimiento por parte de los sujetos de que la puesta en marcha de ese proyecto político requiere fundamentalmente que deseen aquello que se ha predispuesto para ellos anticipadamente.

Con lo cual se descarga contra los dominados, especialmente contra los sectores más vulnerables, una violencia simbólica que consiste en la producción de un imaginario doble; en el que convergen tanto la plenitud como la impotencia.Puesto que, el disfrute prometido a los ciudadanos como premio de sus sacrificios y resignaciones del presente, en post de una felicidad futura, está destinado al fracaso dado que, el deseo que mueve a estos sujetos -por las mismas condiciones reales de existencia- se extiende indefinidamente.

Pero, como señala Lordon, esta fantasía es tan sospechosa como improbable puesto que, aunque a menudo el enrolado muestre señales de que está identificado y apasionado con lo que hace, como señalara Marx, la compra de la fuerza de trabajo "no conlleva ninguna garantía de su futura movilización efectiva" (Lordon, 2015: 101) y la remodelación de los deseos se torna para los enroladores, algo incierto. En este sentido, "el recauchutaje de los individuos y su transformación en robots afectivos deja a veces, no obstante, resabios extraños. La otra cara -la cara risueña y encantada- de la utopía neoliberal quisiera más bien tomar la forma de una bella comunidad espontánea de individuos idénticamente deseantes" (Ibíd.: 100).

La posibilidad de sublevarse señalada por Lordon, se encuentra también presente en la reflexión de Pêcheux para quien es imposible la sujeción "perfecta" al interior del proceso de trabajo impuesto por el modo de producción capitalista. Esta imposibilidad de lograr una sujeción plena es ilustrada con el relato autobiográfico- sobre el trabajo en cadena- de un militante intelectual contratado durante un año en una de las fábricas de Citroën de la región parisina, que sostiene lo siguiente:

Quizás podría decirme que nada tiene importancia, que basta con habituarse a hacer siempre los mismos idénticos gestos sin aspirar más que a la plácida perfección de la máquina. Tentación de la muerte, pero la vida se niega, resiste. El organismo resiste, los músculos resisten, los nervios resisten. Algo, en el cuerpo y en la cabeza, se yergue, tenso, contra la repetición y la nada. La vida se insinúa en un gesto más rápido, un brazo que cae fuera 
de ritmo, un paso más lento, una pizca de irregularidad, un falso movimiento, "remontar", "hundirse", la táctica de cada puesto. Todo eso por lo cual, en ese ridículo punto de resistencia contra la eternidad vacía que es el puesto de trabajo, hay aún acontecimientos, aunque sean minúsculos, hay todavía un tiempo, aunque sea monstruosamente estirado. Esta torpeza, ese desplazamiento superfluo, esa súbita aceleración, esa soldadura mal hecha, esa mano que insiste por segunda vez, esa mueca, ese "descuelgue", eso es la intromisión de la vida, es todo lo que en cada uno de los hombres de la cadena grita silenciosamente: “¡Yo no soy una máquina!”.

(Citado por Pêcheux, 2015: 17, N/ T 19)

La estrategia de Lordon apunta entonces a mostrar que la ideología neoliberal es una causa incausada que se manifiesta en sus efectos, cuya pretensión de ocultar la dominación ideológica, es impedida por la existencia material y concreta del conflicto y las luchas sociales, que exceden y desbordan esas pretensiones.

Todo este rodeo por la propuesta de Lordon nos permite reforzar que es justamente a través de lucha de clases que se desestabiliza la lectura funcionalista y reproductivista de la propuesta althusseriana. Así como constituye u aporte, a nuestro parecer, para remover las lecturas enquistadas que presentan a Althusser como un "un partisano de la estructura contra la agencia, cuya teoría vuelve el cambio social impensable" 113 .

Ahora bien, desde nuestra lectura, existen fuertes vínculos entre propuesta de Lordon de enfatizarla dimensión afectiva de la interpelación, y lo desarrollado por Althusser en las Tres notas sobre la teoría de los discursos, donde la interpelación es comprendida como una empresa de persuasión, y que examinaremos en el próximo capítulo.

113 Entrevista a Montag del 09/09/2018. Disponible online: http://www.laizquierdadiario.com/ParaAlthusser-la-filosofia-debe-sacudir-las-cosas. 


\section{Capítulo VII. La interpelación como persuasión discursiva}

...en la ideología todas las preguntas se responden por adelantado, por esencia, puesto que el discurso ideológico interpela-constituye a los sujetos de su interpelación proveyéndoles por adelantado la respuesta a la pregunta fingida que contiene su interpelación...

(Althusser, Tres notas sobre la teoría de los discursos)

En este capítulo proponemos mostrar como objetivo central que el abordaje de la interpelación ideológica en las Tres notas sobre la teoría de los discursos -que tienen como eje central la articulación entre la estructura del inconsciente y la estructura de la ideología desde una teoría materialista de los discursos- permite comprender la interpelación como una empresa de persuasión discursiva por su apelación al componente afectivo, lo que permite comprender la respuesta a un mandato social y resuelve (anticipadamente) muchas de las críticas que recibe el planteo de la interpelación ideológica en el ensayo de 1970.

En este sentido, analizaremos comparativamente las propuestas de las Tres notas y de Ideología y aparatos, mostrando que el tratamiento de la ideología desde una teoría materialista de los discursos que hay en las primeras, es abandonado en Ideología y aparatos... donde la interpelación ideológica está vinculada a las prácticas que prescriben los AIE.

Proponemos leer críticamente este abandono por parte de Althusser atendiendo a un desliz que aparece hacia el final de las notas de 1966. Así como leeremos críticamente el silencio teórico de Althusser en las Tres notas... en torno a los mecanismos específicos por los cuales se producen subjetividades generizadas, que ocupan lugares diferenciales de la estructura social. Lo que será abordado en la III parte de este trabajo, titulada "Ideología y género". 


\section{Las Tres notas sobre la teoría de los discursos}

No podemos proferir una palabra, a menos que la recordemos (...) No está en el poder del alma el recordar u olvidar nada.

(Spinoza, Ética)

La primera aparición del concepto de interpelación ideológica se encuentra en las Tres notas sobre la teoría de los discursos escritas en 1966 como parte de una contribución de Althusser a la discusión en torno al concepto de discurso. Esta discusión se inicia cuando este envía una carta a su círculo más íntimo para invitarlos a participar en Grupos de Trabajos Teóricos (GTT) para reflexionar en torno a la coyuntura política de la época siguiendo lo realizado unos meses antes con la conferencia titulada "Coyuntura filosófica e investigación teórica marxista"114.

En las Tres notas... Althusser continúa lo explorado en Freud y Lacan, en Psicoanálisis y Ciencias Humanas y en las Cartas a D...en torno al estatuto del psicoanálisis, su objeto y la relación de este con la psicología. Así, en la nota 1 [titulada: sobre el psicoanálisis] Althusser señala que la teoría psicoanalítica se encuentra en forma de una teoría regional, que carece o tiene ausente una teoría general, aunque se encontraría en la búsqueda de esta última- de la que un comienzo de elaboración, aún insuficiente, sería detectable en los trabajos de Lacan a partir del establecimiento de la relación diferencial entre el objeto del psicoanálisis y el objeto de la lingüística: la teoría general del significante.

Respecto al objeto de la teoría psicoanalítica, se trata del inconsciente analítico, que no es el objeto real al que se refieren la práctica de la cura y sus observaciones; sino un objeto teórico que permite pensar también en lo que sucede fuera de la cura y fuera de los casos patológicos. Ya que se trata de "la teoría de todos los efectos posibles del inconsciente, en la cura, fuera de ella, en los casos patológicos, y en los "normales"" (EP: 106). De modo que lo que caracteriza a la teoría psicoanalítica como teoría es tener un objeto de conocimiento ("la teoría se constituye para producir su propio objeto y su conocimiento" Ibíd.: 107), para producir el conocimiento de la posibilidad determinada de los efectos, y por ende de los posibles efectos de este objeto en sus formas de existencia reales.

Sin embargo, se trata aún, según Althusser, de una teoría regional que depende

\footnotetext{
${ }^{114}$ Ver el estudio preliminar de François Matheron, en EP: 99-103.
} 
de una teoría general ausente, en sentido teórico y práctico. En sentido teórico implica que la teoría regional intenta definir su objeto diferencialmente (con respecto a otros objetos teóricos como el de la biología, la psicología, la sociología, etc.) sin lograrlo. Este fracaso, revela, según Althusser, la falta de una teoría general. En cuanto a la ausencia de esta en el plano práctico, Althusser señala que la falta de delimitación del objeto teórico del psicoanálisis, tiene efectos concretos en la práctica de esta disciplina, como el de poder responder las siguientes preguntas: “¿cómo conducir una cura de psicóticos?; ¿qué relación existe, práctica y técnicamente, entre la cura analítica y las psicoterapias?" (Ídem). Todo lo cual tendría como consecuencia, la "caída en el empirismo de la práctica analítica, o a su confusión con otras teorías regionales (...) hasta en el plano de la técnica" (Ídem).

Althusser afirma que los efectos de esta ausencia pueden ser relativamente limitados. Ya que puede haber prácticas justas aun cuando no se domina, por ejemplo, la teoría regional desde el punto de vista teórico. Del mismo modo, puede haber practicantes que no la practican, pero practican una teoría falsa; o analistas que dominan teóricamente la teoría general y que pueden al mismo tiempo "practicarla". En cualquier caso, dice Althusser, el psicoanálisis sigue siendo -limitadamente- una teoría regional. Que el psicoanálisis no disponga de teoría general, sino ya sea una práctica o de una teoría regional, le da este estatus sumamente particular: no está en condiciones de dar una prueba objetiva de su cientificidad. La única prueba que puede darse de la cientificidad de una teoría regional es exhibir la articulación diferencial que la sitúa en el campo articulado de los objetos teóricos existentes. Sólo la teoría general puede asegurar esa función.

Ya en Freud se encontraría -según la lectura althusseriana- una tentativa de situar el objeto del psicoanálisis con respecto a otros objetos, pertenecientes a disciplinas existentes, lo que prueba la conciencia de Freud de pensar el objeto teórico del psicoanálisis en el campo de la objetividad científica. Mientras que Lacan no sólo sostiene ferozmente el principio de la diferenciación entre el objeto del psicoanálisis y el de la biología, sino que agrega a esta distinción, la exhibición de lo que distingue y lo que reconcilia a los objetos teóricos correspondientes a ambas disciplinas. Es decir, que piensa una relación diferencial que sirve a su vez para pensar otras relaciones diferenciales: con los objetos de la biología, de la psicología, de la sociología, de la filosofía. Una relación diferencial que no se trata de una causalidad teórica. Bajo la perspectiva de Althusser, al elaborar la teoría regional del psicoanálisis, Lacan se ve 
llevado no sólo a esclarecer los conceptos teóricos de la teoría regional analítica sino también a algunos conceptos de la lingüística, la teoría general a la que recurre. Se trata de un efecto normal de la aparición de cualquier teoría general: rectifica- reclasifica los conceptos que enfrenta, confrontando a una teoría regional a la que se intenta hacer avanzar.

Pero, aclara Althusser, la teoría general del psicoanálisis no puede elaborarse por la simple confrontación diferencial entre la teoría general de la lingüística y la regional del psicoanálisis, sino que debe ser elaborada desde otro punto de vista; por medio de diferentes confrontaciones, haciendo intervenir otras teorías regionales y sus relaciones diferenciales, con una reclasificación diferente. Lo que sugiere Althusser es buscar la teoría general del psicoanálisis en lo que permite constituir la teoría regional del discurso del inconsciente, al mismo tiempo como discurso y como discurso del inconsciente.

Para ello, propone partir de las características del inconsciente, del que destaca: a) que se manifiesta, existe, por sus efectos; b) lo que existe son las formaciones del inconsciente que producen efectos determinados; c) el inconsciente es una estructura que combina determinados elementos sometidos a leyes de combinación determinadas; d) estos elementos son significantes; e) estos significantes son los del inconsciente, por tanto, depende de la teoría general que permite pensar esta diferencia. Teoría que "por el momento" es dejada en suspenso; f) la diferencia especifica entre el discurso de la ciencia, el de la ideología, el del arte, el del inconsciente, debe ser posible por las diversas variaciones posibles inscritas en la teoría del discurso; g) es necesario poner en evidencia “por reducción”, esta diferencia y compararla con lo que la teoría del significante es capaz de producir como efecto teórico requerido; h) todo discurso produce un efecto de subjetividad, tiene como resultado, un sujeto, que es uno de los efectos, pero no el principal de su funcionamiento; i) la teoría de la producción del efecto de subjetividad compete a la teoría del significante. Esta debe dar cuenta no sólo del efecto-sujeto, sino también de las distintas formas del sujeto; k) Al comparar entre los diversos efectos- sujetos producidos por las diferentes formas del discurso se comprueba que la relación de estos sujetos con los discursos, cambia en cada caso; por otra parte, se advierte que cambia la posición del sujeto "producido" o inducido por el discurso con respecto al discurso.

En este sentido, el sujeto ideológico está presente en persona en el discurso ideológico, mientras que el sujeto científico está ausente en persona en el discurso de la 
ciencia. La naturaleza diferencial del efecto-sujeto y el lugar (posición) que ocupa con respecto al discurso considerado, deben ser referidos a diferencias de estructura. Ejemplo: "el discurso ideológico, en el que está presente el efecto-sujeto en persona, es pues significante del discurso, es el significante central del discurso, posee una estructura de centrado especular: el sujeto es producido por un sujeto productor (Dios, sujeto trascendental, etc.). Por otra parte, el "discurso científico" en el que está ausente el efecto- sujeto en persona, posee una estructura de descentrado: la de un sistema de relaciones abstractas, cuyos elementos son conceptos, y ninguno es constituyente.

Por otra parte, Althusser detecta que 1) los significantes de cada discurso son diversos. Así, mientras que los discursos de la lengua son los fonemas; los de la ciencia son conceptos, palabras; los del estético son colores, palabras, sonidos, etc.; los del discurso ideológico son diversos (materia: gestos, conductas, sentimientos, palabras); y los significantes del inconsciente son fantasmas; m) la especificidad de cada estructura y de sus efectos- sujeto, depende de la función específica de cada una; n) así en el discurso científico distingue la función de conocimiento; en el de la ideología, de reconocimiento- desconocimiento; en el arte de reconocimiento- percepción; y de la circulación de significantes en el caso de la lengua; o) en el caso de la estructura del inconsciente, el modo de articulación es el siguiente: “en cualquier formación social, la base requiere la función- soporte (Träger) como una función para asumir, como un lugar que debe tener en la división técnica y social del trabajo. Esta requisión queda abstracta: la base define funciones- Träger (la base económica y asimismo la superestructura política e ideológica) pero a la estructura (base o superestructura) que define estas funciones le importa poco quién deba ocupar y ejecutar esta función (...) no quiere saberlo (como en el ejército)" (EP: 117-118. La cursiva es del original. La negrita es nuestra).

Que la estructura de la formación económica- social sea impersonal, según Althusser, y que poco importe quién y por qué ocupa determinado lugar de la estructura social y económica, constituye - desde nuestra perspectiva- una ceguera por parte de Althusser, respecto al modo específico en que se producen subjetividades generizadas, para ser sujetadas a determinados lugares de la estructura social.

En el marco de las Tres notas... los "lugares vacíos" se llenan gracias a la articulación entre las instancias económico- social e ideológica. La ideología es la que asegura la función de designar el sujeto (en general) que debe ocupar la función- sujeto. Althusser insiste en afirmar que la ideología se articula sobre las estructuras económicas 
y políticas por el hecho de permitir funcionar a la función- Träger, transformándola en función- sujeto.

Efectivamente, dado que, en cualquier formación social, la base requiere ${ }^{115}$ la función- soporte (Träger) como una función para asumir, como un lugar que debe tener en la división técnica y social del trabajo. La ideología se articula sobre las estructuras económicas y políticas por el hecho de permitir funcionar a la función Träger, transformándola en función -sujeto. Para ello, la ideología debe interpelarlo como sujeto, es decir, transformar la función- Träger (impersonal) en función- sujeto, brindándole razones de sujeto para asumir esta función de sujeto definida por la estructura. Althusser señala que, estas razones de sujeto "figuran con todas sus letras en su discurso ideológico que es, necesariamente, un discurso referido al sujeto al que se dirige, que implica también necesariamente al sujeto como significante del discurso, y por ello el sujeto debe figurar en persona entre los significantes del discurso ideológico" (EP: 118).

Ahora bien, para que el individuo se constituya en sujeto interpelado, es necesario que se reconozca como sujeto en el discurso ideológico, tiene que figurar en él (en persona): de ahí una primera relación especular, que permite que el sujeto interpelado pueda verse en el discurso de la interpelación. Cabe señalar en este sentido que, de acuerdo con la genealogía de la interpelación ideológica esta es entendida como la acción policial de detener a un individuo y de exigirle identificación ${ }^{116}$ tratándose por lo tanto de una interrupción poco deseada por parte de quien es apartada y llamada a "responder"- tomando así la forma de un mandato.

Este énfasis de las Tres notas...en el mandato que supone la interpelación ideológica se diluye en Ideología y aparatos, donde la interpelación es pensada como un llamado ante el cual los individuos responden, y se constituyen en ese mismo acto en sujetos. En el ensayo de 1970, la ideología "recluta" (supone consentimiento) sujetos

\footnotetext{
115 Montag advierte que los verbos "reclutar" (recruits), y "requisar" (requires) son términos que provienen del ámbito militar y que denotan el acto mediante el cual el ejército repone sus filas. En este sentido, mientras que la reclusión involucra el consentimiento del individuo para enrolarse en las filas; “'requisar' en francés y en inglés significa un mandato (command) que no contempla el consenso del individuo cuya propiedad o persona está siendo expropiada, ni tolera negativa alguna" (Montag, 2015: 28).

116 "interpellation" as opposed to "recognition" implies an inequality of force: we obey the police officer and furnish proof of our identity (the singularity of a face or a fingerprint) who stops us not because we require his recognition to become conscious of ourselves as subjects, but because he demands it of us and his demand takes place in the context of physical constraint, real or threatened, together with violence and physical pain enacted or left in suspension (...)" (Montag, 2013b: 137).
} 
entre los individuos (los recluta a todos) o transforma a los individuos en sujetos- los transforma a todos, por medio de la interpelación" (IAEI: 55), de acuerdo a lo que la estructura social "requiere".

Sin embargo, Althusser aclara en las Tres notas...que la ideología no es un simple mandamiento “(que de nuevo sería una forma de 'no quiero saberlo'); este reconocimiento no es una violencia cruda (la violencia cruda no existe), no es una exhortación pura y simple, sino una empresa de persuasión: debe pues garantizarse a sí misma con respecto al sujeto al que interpela" (EP: 118). Esta interpelación la realiza un Sujeto, ya que "la estructura de centrado de la ideología es una estructura de garantía, pero en una forma tal que contiene en su discurso al sujeto al que interpela (y 'produce' como efecto)" (Ídem.). El sujeto "actúa" como significante del discurso -que posee una estructura de centrado especular, por tanto: el sujeto es producido por un sujeto productor (Dios, sujeto trascendental, etc.).

Ahora bien, Althusser insiste en que la ideología se articula sobre las estructuras económicas y políticas por el hecho de permitir funcionar a la función- Träger, transformándola en función- sujeto mediante la función de repetición de la ideología que permite al Träger de la ideología como tal transformarse en función- sujeto. Puesto que: "La función- sujeto que constituye el efecto propio del discurso ideológico requiere, a su vez, produce o induce (sic) un efecto propio, que es el efectoinconsciente, o el efecto sujeto-del-inconsciente, es decir la estructura propia que permite el discurso del inconsciente. Esta última función permite asegurar la funciónsujeto en el desconocimiento" (EP: 119)

Si analizamos esta última cita de las Tres notas...en articulación con la clasificación de las diversas funciones que tienen los discursos en esta obra de 1966, según la cual la función propia del discurso ideológico es la de reconocimiento/ desconocimiento; donde el reconocimiento, correspondería al ámbito del discurso ideológico, y es posible por la función-sujeto inscripta en la estructura de centrado especular. El segundo efecto, el desconocimiento, se garantizaría a partir del efecto del inconsciente y su discurso.

Dicho esto, cabe hacer otra breve digresión comparativa entre el ensayo Ideología...y las Tres notas.... mientras que, en el primero, Althusser dice que el discurso ideológico es de especularidad, en las Tres notas, es más radical dado que: 
la interpelación como sujetos de los individuos produce en ellos un efecto específico, el efecto inconsciente que les permite a los individuos asumir la función de los sujetos ideológicos, ya que se trata de un mecanismo que produce sus formaciones en situaciones concretas y lo hace a través del discurso ideológico.

En articulación con la estructura del inconsciente, la ideología opera como síntoma de este. Aunque las estructuras del discurso del inconsciente y la del discurso ideológico son diferentes, para Althusser cabe pensar que algo del discurso ideológico es "proseguido" en la estructura del discurso del inconsciente, pero en forma de ausencia radical. Althusser subraya que hay algo del gran Otro que habla en el discurso del inconsciente, que no sería el sujeto del discurso de lo ideológico Dios, el Sujeto, etc., sino “el propio discurso de 'lo ideológico' instaurado como sujeto del discurso del inconsciente" (Ídem).

Ahora bien, el efecto del inconsciente, lleva en sí mismo, dice Althusser, "la marca de lo que fue necesario desechar, de aquello respecto de lo cual hubo que tomar distancias" (Ibíd.: 120). Se trata, en definitiva, de una forma de olvido, que estrecha fuertes vínculos con la teoría del decreto de Spinoza, según la cual aquello que se decreta, guarda una profunda relación con el olvido ${ }^{117}$. Para Montag (2015) el escolio "ni el cuerpo puede determinar al alma, ni el alma puede determinar al cuerpo al movimiento o al reposo" (E, III, prop. 2) ${ }^{118}$ constituye un intento de desarrollar las alusiones a la memoria y el olvido, hechas al pasar, en una teoría del decreto.

De acuerdo con esta lectura, el escolio afirma que sólo los cuerpos pueden determinar a los cuerpos a moverse; Spinoza, reconocería, según Montag que, existe un supuesto de que el alma ejerce un "comando" sobre el cuerpo y puede determinarlo a moverse o a detenerse, lo que se comprobaría a través de determinadas acciones, entre las que se destaca la de hablar. Para Montag:

${ }^{117}$ El olvido significa "recubrimiento de la causa del sujeto al interior mismo de su efecto" (Pêcheux, 2016: 145, nota al pie nro. 219). El sujeto se constituiría por el olvido de aquello que lo determina.

118 Este escolio tendría como interlocutor central al Cicerón estoico y epicureísta que rechaza la causalidad final (la Providencia) y que vincula la moralidad con la corporalidad (su placer y su dolor). Para Epicuro, en la lectura que hace Cicerón, "el dolor es contrarrestado (compensabatur) por el placer (laetitita) que obtengo del recuerdo de mis teorías y descubrimientos" (De Finibus II, 96). Esta equivalencia entre un dolor que puede ser compensado a partir del placer que confiere un recuerdo, tiene a mi entender, importantes resonancias en la lectura que Lordon realiza del significante capital, en el marco de la "ideología neoliberal" aunque el autor no mencione a Cicerón. 
Ninguna acción podría aparecer en una relación más íntima con el pensamiento, es decir, espacial y temporalmente inmediata y carente de intermediarios, que el discurso. El discurso se presenta como una transcripción instantánea del pensamiento a un sistema convencional de sonidos y como tal sufre menos interferencia del cuerpo que otras acciones. Lo que es más aún, el alma está presente en sus palabras para garantizar su correspondencia con los pensamientos que expresa. ¿Quién podría convencerse de que él mismo no es el autor de su propio discurso y de que no determina las palabras que profiere?

(Montag, 2015: 18)

Para designar la determinación del cuerpo por el alma, Spinoza utiliza el término decretum, que significa una asimetría tanto en términos de derecho y de fuerza, que puede ser traducido en castellano como "decreto". El "decreto", señala Montag, "incluso el decreto que nos decretamos a nosotros mismos, en contraste con otras acciones del cuerpo, está compuesto de palabras que no se originan en nosotros..." (Montag, 2015: 19). Sino que, el decreto de las palabras que proferimos está determinado previamente y nos excede. Así, “lo que 'viene al alma' está decretado, es el efecto de un decreto dirigido a una comunidad de hablantes, de creyentes. Pero uno por uno, individualmente y desde dentro, de modo que cada uno lo reciba por separado" (ídem). Cabe recordar en este sentido lo señalado en el cap. IV acerca del pasaje de Ideología y aparatos que dice así:

...diremos pues, considerando sólo un sujeto (un individuo), que la existencia de las ideas de su creencia es material, en tanto esas ideas son actos materiales insertos en prácticas materiales, reguladas por rituales materiales definidos, a su vez, por el aparato ideológico material del que proceden las ideas de ese sujeto. Naturalmente los cuatro adjetivos "materiales" inscritos en nuestra proposición deben ser afectados por modalidades diferentes, ya que la materialidad de un desplazamiento para ir a misa, del acto de arrodillarse, de un ademán para persignarse o para indicar mea culpa, de una frase, de una oración, de un acto de contrición, de una penitencia, de una mirada, de un apretón de manos, de un discurso verbal externo o de un discurso verbal "interno" (la conciencia), no son una sola y misma materialidad. Dejamos en suspenso la teoría de la diferencia de las modalidades de la materialidad.

(IAEI: 50) 
En este sentido, la creencia del creyente, y su fe, se manifiestan y existen materialmente en "los movimientos del cuerpo al ir a misa, al arrodillarse, hacer la señal de la cruz, golpearse el pecho tres veces en el preciso momento que profiere las palabras 'mea culpa, mea culpa, mea máxima culpa'” (Montag, 2015: 20). Para Montag, en ese pasaje existe la modalidad de un discurso verbal externo, un discurso muy específico, cuyas palabras y secuencia son prescriptas, y que ocupa un lugar entre otras acciones materiales, en un ritual que requiere que cada individuo lo represente" (Ibíd.: 22).

El concepto de discurso operando en Ideología y aparatos se encuentra ubicado "en entrelíneas", y funciona en demarcación con la noción de conciencia, interioridad subjetiva (sino como un interior que es la continuación de un exterior). Puesto que:"la noción de discurso, social y transindividual por su naturaleza, excluye la idea de un interior, de un pensamiento, creencia o fe, como productos de la actividad autónoma de un alma "propia"” (Ídem.).

Ahora bien, el problema que Spinoza vislumbraría en el famoso escolio, siguiendo con esta lectura de Montag, sería no el de saber si el alma puede mover al cuerpo, sino el de lo que se puede y no se puede decir, o lo que no se puede recordar, como plantea Cicerón:

¿Está realmente en nuestro poder el determinar lo que recordamos (in nostrane ptestate est, quid meminerimus)?” ¿No fue Temistocles quien, al tener la oportunidad de aprender el arte de la memoria, declaró que 'preferiría aprender el arte del olvido, pues recuerdo lo que no quiero recordar y no puedo olvidar lo que quiero olvidar (Nam memini etiam quae nolo, oblivisci non possum quae volo)? (cfr. Montag, 2015: 17) ${ }^{119}$

Ahora bien, de acuerdo con lo examinado en el Tratado teológico político la presencia del ritual que comandaba casi todas las actividades de la vida del pueblo hebreo era una obediencia del pueblo a la palabra (decreto) de Dios a través de Moisés. Este decreto guarda una relación con el desconocimiento, en la medida en que "nuestro propio decreto, un decreto que nos hemos decretado a nosotros mismos decretar, es de

\footnotetext{
119 De acuerdo con esta lectura, siguiendo los ejemplos de Descartes sobre el cuerpo como una máquina que se mueve a sí misma, "Spinoza debe apelar a fenómenos como sonambulismo (haciendo referencia a la 'impresionante' variedad de cosas que los sonámbulos pueden lograr inconscientes) para demostrar 'lo que el cuerpo puede y no puede hacer sin ser determinado por el alma' (Ídem).
} 
hecho el decreto al que estamos sujetados en relación a lo que debe, puede y no puede ser dicho" (Ibíd.: 18).

El decreto que sujeta por medio de la interpelación ideológica entonces, se dirige a los individuos para obligarlos a asumir las funciones de Träger requeridas por los diferentes niveles de la estructura social. En este sentido, la forma en la que el discurso ideológico interpela a los individuos es tal que permite al sujeto interpelado reconocerse y reconocer su lugar en el discurso "al mismo tiempo que le garantiza que en efecto es él el interpelado, y que es interpelado por alguien, otro Sujeto (...) que es el centro del cual emana toda interpelación, el centro de toda garantía..." (Ibíd.: 120).

\section{Sujetos persuadidos y reclutados por los discursos}

Si el discurso produce la identidad, suministrando e imponiendo un principio regulador que invade completamente al individuo, lo totaliza, le otorga coherencia, entonces parecería que, en la medida que es totalizadora, toda identidad actúa precisamente como alma que encarcela al cuerpo.

(Butler, Mecanismos psíquicos del poder)

La interpelación ideológica está destinada a asegurar el reclutamiento de los individuos por la garantía que da a los reclutados; Althusser dice, "los instaura como sujetos al mismo tiempo que los recluta", en un mismo acto. Lo que manifiesta la circularidad de la estructura de centrado especular de la ideología, y por la que, todas las preguntas se responden por adelantado, se trata de preguntas fingidas puesto que las respuestas ya están dadas de antemano. Es por ello, que el discurso ideológico sólo tiene sentido como interpelación. No se pregunta “¿hay sujetos para asumir las funciones de Träger?" Porque se corre el riesgo de no recibir respuesta. Frente a lo cual se parte de la "pregunta resuelta, es decir, de la respuesta que no es la respuesta a una pregunta, pues de ninguna manera la pregunta es muestra de la competencia del discurso ideológico" (EP: 121).

Más importante aún: el discurso ideológico, da por supuesto al sujeto, lo hace existir para que sea posible la interpelación ideológica que "no se dirige más que 'a un sujeto presuntamente existente', y se le proporcionan ${ }^{120}$ sus documentos de identidad para demostrarle que es el sujeto al que se interpeló" (Ídem.). Existe así, un paralelismo

\footnotetext{
${ }^{120}$ En nota al pie se añade: "Es la prefectura de policía la que proporciona a los individuos a los que los policías interpelan los documentos de identidad que los susodichos policías piden (exigen) que se exhiban" (Ídem).
} 
entre el modo de operar de la ideología y el de la policía que actúa sometiendo al sujeto interpelado al que le solicita los documentos de identidad "sin presentar a su vez sus documentos de identidad, pues lleva el uniforme de sujeto que es su propia identidad" (Ídem). Es decir que, el discurso ideológico recluta produciendo él mismo los sujetos a los que recluta. Puesto que, para el discurso ideológico, sólo hay sujetos ideológicos, tanto como para la ideología militar siempre ya hay militares, por ejemplo.

No obstante, inmediatamente después de esta afirmación Althusser postula la siguiente ambigüedad: "Si bien la estructura recluta a los individuos como sujetos para asumir la función Träger, la requisición de la estructura está en blanco, es abstracta, anónima: no quiere saber quién asumirá las funciones de Träger" (Ibíd.: 121. Cursiva del original, la negrita es nuestra). El discurso ideológico es el "que provee los quien" ya que, "interpela individuos en la forma general de la interpelación de sujetos. Es pues personal "concreta", no está en blanco, sino "como lo dice abiertamente la ideología de la industria de masas, "personalizada"” (Ídem.).

Pero ¿qué es lo que hace que los individuos asuman la función de sujetos (ideológicos)? Contra la suposición de Zizek, para quien Althusser no se ocuparía de explicar por qué los individuos responderían al llamado de interpelación/ identificación, Althusser explica (unos cuantos años de que el esloveno formule esa crítica) que, "la interpelación a los individuos como sujetos ideológicos produce en ellos el efecto inconsciente que les permite asumir la función sujeto" (Ibíd.: 122). El inconsciente que "está estructurado como un lenguaje" constituye un discurso que produce un efectosujeto, que figura en él por lugartenencia (lo que es lo mismo, es representado por un significado en el sentido lacaniano). Esta producción, aclara Althusser, no tiene el sentido de una génesis, sino "el de una articulación diferencial” (Ídem). Profundizando la crítica al concepto de génesis como origen que realizara en la Carta a D...

Hacia el final de la nota 1, Althusser señala que el discurso ideológico sirve de síntoma para el discurso del inconsciente en cuestión. A pesar de que la estructura del discurso del inconsciente es totalmente diferente de la estructura del discurso ideológico “puesto que no está centrada y el 'sujeto' del inconsciente no figura en persona, sino por 'lugartenencia' en el discurso del inconsciente" (Ibíd.: 126). En consecuencia, Althusser pregunta si hay algo de la estructura del discurso ideológico que dependería justamente de la estructura del discurso del inconsciente, y responde que se encuentra "en forma de ausencia radical, cuya presencia en persona en la estructura del discurso de lo 
ideológico marca el contraste diferencial, el gran otro lacaniano, que es propiamente el ‘sujeto’ del discurso del inconsciente” (Ibíd.: 126- 127).

En este sentido, el gran Otro, que habla en el discurso del inconsciente, sería entonces "el propio discurso de lo ideológico instaurado como sujeto del discurso del inconsciente, y en la forma específica de dicho sujeto, es decir como efecto de este discurso, presente en los significantes del mismo como ausente por representación bajo un significante (presente-ausente por "lugartenencia")" (Ibíd.: 127).

Ahora bien, Althusser señala que los diferentes discursos se relacionan a partir de un tipo de articulación diferencial: el materialismo histórico que los relaciona con los otros discursos. En este marco, la teoría general de la que depende la teoría regional del objeto psicoanalítico es una combinación de la teoría general del significante y de la teoría general del materialismo histórico "en la que la segunda determina a la primera (...) se articula sobre ella" (Ibíd.: 130). La articulación diferencial de estas dos teorías generales es la que permite distinguirlas y la que permitiría, según Althusser, tanto "dar cuenta de la legitimidad de la tentativa de Freud, y al mismo tiempo criticar sus silencios teóricos, a los cuales se sobreimprimieron discursos ideológicos" (Ibíd.: 132. La cursiva es del original, la negrita es nuestra).

Althusser señala que la indagación de la teoría general permitiría mostrar que en los hechos mismos de la cura psicoanalítica "son los elementos que se empalman en el discurso del inconsciente a partir del discurso ideológico, aquellos en los que el discurso del inconsciente debe 'deslizarse' para realizarse" (Ibíd.: 133). Es decir, verificar que hay una repetición del discurso del inconsciente en la estructura del discurso de lo ideológico.

Por otra parte, cabe señalar que en la Nota 2 Althusser problematiza el hecho de que decir que el inconsciente está "estructurado como el lenguaje", es decir, tratar el inconsciente como discurso, puede hacer perder de vista lo específico del inconsciente, lo que lo constituye, esto es: la libido y las pulsiones (aquí encontramos una respuesta anticipada a la crítica de Butler). En esta objeción althusseriana se encuentra la idea de que "lo que es designado por el concepto de discurso aplicado al inconsciente no puede dar cuenta de la realidad específica del inconsciente" (Ibíd.: 135). Sin embargo, estos riesgos se disipan al reconocer que cada tipo de discurso se define por medio de un sistema de limitantes específicas; las del discurso inconsciente hacen que funcione produciendo el efecto libido (así como las del discurso científico producen el efecto conocimiento; y las del discurso ideológico, el efecto desconocimiento/ 
reconocimiento). Se trata de un efecto inmanente puesto que "la libido es tan poco exterior, anterior y trascendente a las formas de 'su' discurso que podemos considerarla como ¡su efecto específico!” (Ibíd.: 137).

Una vez hecha esta aclaración sobre las limitantes específicas, Althusser señala que la articulación del discurso inconsciente sobre el discurso ideológico es una articulación principal (si bien, también se articula sobre otros discursos como el científico y el estético, pero aquí se trata de articulaciones segundas). El discurso ideológico es uno en el que se encuentra presente "el efecto-sujeto en persona"121; mientras que en el discurso del inconsciente, el gran otro lacaniano, que es el 'sujeto' de este discurso, sería el propio discurso de lo ideológico instaurado como sujeto del discurso del inconsciente, y en la forma específica de dicho sujeto (Ibíd.: 138).

Efectivamente, en esta nota Althusser enfatiza que "el inconsciente es un mecanismo que funciona macizamente con lo ideológico"; que implica, no obstante, la articulación diferencial entre ambos discursos y sus efectos específicos. Las formaciones del inconsciente se producen sobre las formaciones del discurso ideológico, elemento estructurante de la situación vivida. Puesto que es en los mecanismos inconscientes -que producen los efectos inconscientes (formaciones inconscientes) donde Althusser ubicará que es donde opera el mecanismo ideológico. Así como opera mediante los significantes, los elementos que se combinan en la estructura inconsciente. En este sentido, el concepto de inconsciente permite pensar la constitución de lo social y de lo individual no ya como realidades separadas, sino como efectos de estructuras relativamente autónomas y articuladas.

\section{Discursos y producción de subjetividades}

...la subjetividad está esencialmente fabricada y modelada en el registro de lo social. Descartes quiso unir la idea de subjetividad consciente a la idea de individuo (unir la conciencia subjetiva a la existencia del individuo) y hemos estado envenenándonos con esa ecuación a lo largo de toda la historia de la filosofía moderna.

(Guattari y Rolnik, Micropolitica. Cartografias del deseo)

\footnotetext{
${ }^{121}$ Para Montag, "el sujeto convocado estrictamente hablando, está ausente hasta que el llamado lo hace presente. En este sentido, el discurso ideológico interpela al individuo al 'imputarle' agencia designándolo como causa incausada de su discurso y de sus acciones por las cuales adquiere toda la responsabilidad" (2015: 27).
} 
Finalmente, en la Nota 3 Althusser afirma la necesidad de desarrollar una teoría materialista de los discursos, para poder definir diferencialmente los discursos específicos tales como: el discurso científico, el discurso estético, el ideológico y el inconsciente (el filosófico es dejado de lado, y según Althusser, debe ser distinguido del filosófico como tal). Entre estas distinciones están las estructurales, con elementos y limitaciones propias de acuerdo con las cuales, por ejemplo, en el discurso científico los elementos son conceptos, en el discurso del inconsciente son fantasmas primarios; mientras que en el discurso ideológico hay elementos de distintos niveles. En los más abstractos nos encontramos con representaciones, conceptos; mientras que en un nivel más concreto nos encontramos con gestos, conductas, permisos, prohibiciones.

Además, cada uno de estos discursos se relaciona de manera distinta con la categoría sujeto, de allí que Althusser sostenga que "no podamos servirnos de la categoría sujeto de manera unívoca, ni siquiera como indicio para cada uno de los discursos" (EP: 141). Cada uno de los cuatro discursos tendría un efecto de subjetividad específico. Y el "lugar del sujeto" en cada uno de estos remite a la estructura de cada uno de los discursos. Puesto que, la función- sujeto no es preexistente, sino que comienza a operar en cada caso concreto, lo que desestabiliza las lecturas funcionalistas. Sin embargo, al final de esta nota Althusser reformula su posición respecto al tipo de subjetividad que corresponde a cada tipo de discurso y afirma que la noción de sujeto compete cada vez sólo al discurso ideológico, del que es constitutivo: "No creo que se pueda hablar del 'sujeto de la ciencia' o del 'sujeto del inconsciente', sin un juego de palabras y sin acarrear graves equívocos teóricos" (Ídem)

Con el rechazo a la noción de "sujeto del inconsciente", puesto que el IchSpaltung refiere a "un abismo, un precipicio, una carencia, una abertura" (Ídem); Althusser toma distancia de la conceptualización de Lacan y afirma que la carencia de sujeto, no puede ser llamada "sujeto", por consiguiente, "no hay 'sujeto del inconsciente' aunque no puede haber inconsciente más que por esta relación abismal con el Ich- sujeto de lo ideológico" (ídem). Si para Lacan, el sujeto es el sujeto del inconsciente. Un sujeto que no puede ser nombrado y que se estructura a partir del Otro (significante simbólico) a través de: a) el despliegue de la relación del "yo" con otro "imaginario" (es una ilusión que opera a partir de identificaciones imaginarias); b) el despliegue de la relación del "yo" con el Otro simbólico que implica el ingreso en el orden del lenguaje. Por tanto, siendo que la articulación del sujeto en un significante "yo" es una ilusión que opera a partir de identificaciones imaginarias y simbólicas que 
no tienen que ver con un sujeto del inconsciente: "El 'yo' es otro", está descentrado.

En otras palabras: el sujeto es para Lacan, el efecto imaginario de una articulación significante (significante que tiene como uno de sus efectos de significación, la unicidad del yo). Este "sujeto" se constituye como tal al asumir un significante, y dado que la operación de la metáfora sustituye un significante por otro significante, el sujeto es un significante para otro significante, se representa como tal a través de significantes en la estructura discursiva. Recordemos de acuerdo a lo examinado en "El estadio del espejo" que, en este proceso el sujeto asume una imagen plena (ilusoria) que habilita el ingreso en el orden simbólico que permite la constitución del "уо". De manera que la identificación temprana del infans es la que prefigura la entrada en el lenguaje "que sitúa la instancia del yo, aun antes de su determinación social, en una línea de ficción, irreductible para siempre por el individuo solo (...)" (EE: 100). En los escritos posteriores a El estadio...Lacan sostendrá que estas identificaciones imaginarias están soportadas por el orden simbólico, así: el yo ideal (moi-ideal) se rige en función de las mediaciones simbólicas que le son ofrecidas por el ideal del yo como estructura simbólica.

Ahora bien, una vez realizada esta reformulación Althusser señala que, aunque su trabajo desborda la lingüística, esta no es la teoría general del discurso. El discurso es pensado desde una perspectiva materialista como el articulador entre la ideología y el inconsciente (instancias que no pueden ser pensadas si no es en relación al lenguaje, como discurso). Sin embargo, a pesar del énfasis colocado en la materialidad del discurso, al final de esta nota Althusser rectifica su posición al afirmar que no todo discurso es una práctica, como manifiesta la siguiente cita:

La estructura de un discurso no es la de una práctica. No sólo porque un discurso no produce más que efectos, digamos, de significación, cuando las prácticas originan modificaciones- transformaciones reales en objetos existentes, y en casos extremos objetos nuevos y reales (...) Esto no quiere decir que los discursos no ejerzan eficacia sobre objetos reales, pero si lo hacen es sólo por su inserción- articulación en dichas prácticas, que los utilizan entonces como instrumentos en su "proceso de trabajo".

Los discursos, sostiene Althusser, deben poseer en su interior una doble articulación (similar a la de la lengua, entre morfemas y fonemas), y es la tarea que se 
propone realizar, siguiendo los pasos de Lacan y retomando los aportes de la lingüística que - si antes había sido considerada por Althusser como una teoría regional cuya teoría general se encontraba ausente- al finalizar la última de las Notas, es pensada como el indicio de una teoría general del discurso, la única que en ese contexto puede servir de guía teórica para dar "un estatuto a las leyes generales de todo discurso" (EP: 144).

Ahora bien, que los discursos no produzcan efectos concretos sobre el orden real y que se restrinjan a producir "efectos de significación" (Ibíd.: 143), constituye para nosotros, un desacierto por parte de Althusser, puesto que el efecto del orden significante se encuentra profundamente imbricado con el orden real, tal como observamos a propósito de la articulación entre discurso ideológico y discurso del inconsciente. Los efectos de significación, son de acuerdo a lo señalado en las Cartas a $D \ldots$ (obra en la que Althusser incursiona también en una teoría materialista de los discursos) los efectos de la relación entre significado/ significante, que depende de la estructura del lenguaje. Y este lenguaje atrapa al niño aun antes de nacer, ya que este es arrojado en un mundo estructurado como el lenguaje.

Efectivamente, bajo nuestra perspectiva, el hecho de que para Althusser los discursos "no ejercen eficacia propia sobre objetos reales" (ídem.), constituye un equívoco que lo lleva a abandonar definitivamente su análisis de la ideología y la subjetivación desde una teoría materialista de los discursos para pasar a analizar en Ideología y aparatos... los efectos de la ideología a través de las prácticas materiales reguladas por los $\mathrm{AIE}^{122}$.

Además de este equívoco por parte de Althusser, creemos que existen otras omisiones significativas que operan como síntomas. Una de ellas es el silencio althusseriano en torno a las subjetividades generizadas, subjetividades ${ }^{123}$ otras, no nombradas, que son interpeladas de manera específica y producidas de acuerdo con mecanismos de generización diferenciales. En el caso de lasTres notas...Althusser podría haber dado lugar a esta cuestión cuando afirma que existen distintas posiciones de sujeto, producidos por las diversas formas del discurso. Podría haberle dado existencia a la generización en tanto respuesta a un mandato. Sin embargo, eligió enfatizar que la estructura es anónima, y que no le interesa saber quién ocupará

\footnotetext{
${ }^{122}$ Aunque, desde la perspectiva de Montag, como hemos visto, la indagación discursiva puede ser vista en Ideología y aparatos si se lo hace partiendo de la teoría del decreto de Spinoza.

${ }^{123}$ En este sentido, seguimos la hipótesis de Sergio Calletti (2011) para quien una desustancialización radical de la problemática de la subjetividad supone hablar de los sujetos en vez del sujeto para dar lugar a la pluralidad.
} 
determinado lugar, siempre y cuando este no quede vacío.

Mientras que, en Ideología y aparatos pudo haber planteado esta cuestión crucial (en tanto que el género constituye una estructura de diferenciación y jerarquización primaria), en el momento en que desarrolla los efectos materiales que los diversos AIE tienen sobre las prácticas que prescriben a los sujetos a actuar de determinada manera. Precisamente, en los AIE familiar y en el escolar se desarrollan por excelencia estas prescripciones y diferenciaciones por género.

Para finalizar entonces, siguiendo el protocolo de lectura propuesto por el propio Althusser, proponemos leer sintomáticamente ${ }^{124}$ algunas tensiones en la propia propuesta althusseriana para darle existencia a una problemática que, en nuestra coyuntura singular se torna urgente, a saber la de la articulación entre ideología y género. Es lo que proponemos realizar en la III parte de este trabajo -para seguir profundizando en futuras investigaciones- bajo la siguiente inquietud: ¿a qué se debe el silencio de Althusser en torno a los mecanismos de generización, pese a que esta problemática ya estaba siendo planteada por algunas de sus contemporáneas?

Para finalizar esta segunda parte, creemos que la lectura sintomática sobre el propio Althusser es pertinente en la medida que, como señala Montag en una entrevista del 9 de setiembre del 2018: “fue Althusser mismo quien declaró en Lenin y la Filosofía que leer filosofía de modo materialista es trazar líneas de demarcación en su interior para marcar los conflictos que la hacen ser lo que es". En este sentido, "tomar a Althusser seriamente" es aplicar este protocolo de lectura incluso (o especialmente) a su propia obra, para transgredir un cierto límite que hay en la literalidad de su discurso.

\footnotetext{
${ }^{124}$ Saúl Karsz (1970) señala que la lectura sintomática es aquella capaz de producir el sistema de conceptos capaces de dar cuenta de los silencios y de los blancos, de las ausencias y de las presencias. Para efectuar una lectura sintomática se debe reacomodar la letra, modificar su organización aparente, construir su orden sistemático. Tomar los silencios como indicación de un discurso latente como desplazamiento de un concepto original. Lo cual significa, sobre todo, que se puede y se debe producir conceptos nuevos, inexistentes como conceptos en la letra, pero cuya presencia efectiva permitiría su lectura.
} 


\section{Conclusiones preliminares}

...Sí, en principio estamos unidos por esta institución que es el espectáculo, pero más profundamente estamos unidos por los mismos mitos, por las mismas cuestiones que nos gobiernan sin nuestro consentimiento, por la misma ideología espontáneamente vivida. (Althusser, Bertolazzi el Piccolo y Brecht)

En la segunda parte de este trabajo titulada "Ideología y subjetivación" examinamos que la reformulación del concepto de ideología que propone Althusser constituye una demarcación con los tratamientos de tipo idealistas que suponen al sujeto como categoría central, para pasar a comprenderlo como una categoría derivada de la materialidad de la ideología, profundamente imbricada con la estructura social.

Hemos explorado que al reformular el estatuto de ideología, su naturaleza epistemológica y sus alcances, Althusser también reformula la topografía marxista de la metáfora espacial del edificio compuesto por una base (infraestructura) sobre la que se levantan los dos "pisos" de la superestructura. Esta metáfora, sostiene Althusser, tiene por objeto representar ante todo la "determinación en última instancia por medio de la base económica" bajo dos formas: 1) la de una "autonomía relativa" de la superestructura con respecto a la base; 2) la de una "reacción" de la superestructura sobre la base.

Ahora bien, al reconocer la existencia material de la ideología que se despliega a través de los aparatos ideológicos del Estado -puesto que cada uno de ellos es "la realización de una ideología "- Althusser amplía el análisis marxista que sólo reconocía la existencia del aparato de Estado que incluye no sólo el aparato especializado (el poder judicial, la policía, los tribunales, las prisiones) sino también el ejército. Y distingue así entre ideología primaria (del Estado), y la ideología secundaria como subproducto, en la práctica.

En este marco, se destaca el carácter fundamental que las ideologías ejercen para garantizar el dominio de una clase. En este sentido, Althusser advierte las limitaciones de considerar que el poder del Estado, se asegura únicamente por la fuerza y por la represión. Althusser complejiza y amplía el análisis al postular que ninguna clase puede tener en sus manos el poder de Estado en forma duradera sin ejercer al mismo tiempo su hegemonía sobre y en los AIE -definidos como un sistema de instituciones, de organizaciones y de prácticas correspondientes definidas bajo los que se materializa 
todo o parte (en general, una combinación típica de ciertos elementos) de la Ideología de Estado. Estos aparatos, examina Pêcheux, tienen un doble funcionamiento, además de tendencia a producir conflicto en lugar de orden.

En efecto, la potencialidad de desestabilizar las relaciones de clase es constitutiva de los AIE ya que se encuentran regidos por la lucha de clases "que los atraviesa desde el principio". De manera que, contra las lecturas funcionalistas, en Ideología y aparatos... la primacía de la lucha de clases se encuentra en la distinción entre Ideología en general e ideologías particulares, que se establece en el postcriptum, tal como mostramos en el capítulo IV. En el capítulo V por su parte, examinamos que en el marco de la propuesta de Althusser, la ideología tiene por función central constituir a los individuos en sujetos mediante el complejo mecanismo de la interpelación ideológica, término empleado por Althusser por primera vez en las Tres notas...

La interpelación ideológica -cuya función central es constituir a los individuos concretos como sujetos- es presentada en el ensayo de 1970 como una ilustración de lo que ocurre en la vida cotidiana, cuando, por ejemplo, somos llamados en la calle por nuestro nombre. La práctica de la interpelación ideológica se articula así con una de las evidencias más básicas que tenemos, la de ser sujetos (sobre la que Pêcheux desarrolla la evidencia del sentido). Hemos examinado que la ideología tiene una estructura doblemente especular y una doble naturaleza ya que es tanto material como imaginaria. Esta estructura especular redoblada de la ideología queda asegurada según el esquema presentado por Althusser, por un cuádruple sistema por el cual los sujetos quedan sujetados a la ideología.

Los sujetos "marchan solos" sin necesidad de intervención de los aparatos represivos del Estado -a excepción de "los malos sujetos"- por la dimensión imaginaria, que imbrica la estructura de la ideología con la estructura del inconsciente. En el esquema presentado por Althusser en Ideología y aparatos...es la interpelación la que exige y ordena a los individuos que se comporten como sujetos para ser incluidos entre los sujetos. Y estos se relacionan imaginariamente con su posición de sujeto, que se les presenta a ellos como autónomamente construida, cuando en realidad, como hemos visto, está siempre ya establecida. Analizamos, en este sentido que, la supuesta imposibilidad estructural de escapar de la ideología, y por ende también, la imposibilidad de eludir a la condición de sujetos para ocupar los puestos requeridos por 
el sistema capitalista, ha sido criticado por implicar un funcionalismo y un pesimismo en cuanto a la posibilidad de revertir la dominación ideológica.

En el capítulo VI examinamos específicamente que, las perspectivas críticas de Zizek y de Butler en torno al planteo de la interpelación althusseriana en el ensayo de 1970, reconocen en la falta de agencia de los sujetos (sujetados), el síntoma de una falta de consideración de la dimensión inconsciente, en el caso del primero; y el síntoma de la falta de referencia al elemento pasional del mecanismo psíquico, en el caso de Butler. Frente a estas críticas evaluamos y mostramos que, la articulación entre ideología e inconsciente (operando centralmente a través de Lacan), como así también la primacía de la lucha de clases como elemento transversal de la obra althusseriana, disipan y resuelven las lecturas críticas.

En cuanto a la relación entre ideología e inconsciente, examinamos que ya en textos de 1964 y 1966, publicados en Escritos sobre Psicoanálisis -principalmente Freud y Lacan, Psicoanálisis y Ciencias Humanas, las Cartas a D... y Las tres notas sobre la teoría de los discursos- existe el abordaje de esta articulación. Siendo en las Tres notas... donde Althusser plantea una articulación diferencial entre la estructura del inconsciente sobre la ideología ("el inconsciente es un mecanismo que funciona macizamente con "lo ideológico") desde una teoría materialista de los discursos.

Ahora bien, en cuanto a la primacía de la lucha de clases en la intervención materialista de Althusser, examinamos la propuesta de Pêcheux, y su énfasis colocado tanto en la posibilidad de que se produzcan identificaciones, contraidentificaciones y desidentificaciones; como de enfatizar la reproducción/ transformación de las condiciones de producción.

En el capítulo VII analizamos las tesis centrales de las Tres notas de 1966 con el propósito de mostrar que la interpelación ideológica es planteada en este escrito como una empresa de persuasión que funciona como un mandato, que apela a la dimensión afectiva, profundamente inconsciente. Hemos mostrado en este sentido, que si bien la articulación central entre discurso ideológico y discurso del inconsciente, desde una perspectiva materialista de los discursos fue el eje central de Las tres notas ..., este tratamiento fue abandonado por Althusser en su escrito más célebre: Ideología y aparatos, en el que analiza las prácticas que los AIE prescriben a los sujetos. Por tanto, la relación de inmanencia entre la ideología y las prácticas; y entre la ideología y los sujetos. 
Hacia el final de esta segunda parte, argumentamos por qué leemos sintomáticamente este abandono de una teoría materialista de los discursos, así como el silencio de Althusser en torno a la generización como una determinación primaria, mediante la cual, las subjetividades generizadas deben ocupar lugares diferenciales de la estructura social. Argumentamos así que una lectura sintomática de estos lapsus althusserianos permite formular una nueva problemática: la de la articulación entre "Ideología y género" que desarrollaremos en la tercera y última parte de este trabajo. 
PARTE III. IDEOLOGÍA Y GÉNERO 


\section{Capítulo VIII. Althusser dentro de sus límites}

Así como la comprensión del mundo desde el punto de vista proletario le permite a Marx ir más allá de la ideología burguesa, el punto de vista feminista nos permite comprender las instituciones patriarcales y las ideologías como las convenciones perversas de las relaciones sociales humanas.

(Teresa de Lauretis, La tecnología de género)

Bajo la convicción de que no es para nada inocente lo que se dice y se calla proponemos realizar una lectura sintomática ${ }^{125}$ sobre el silencio de Althusser en torno al proceso de constitución de sujetos con género - (a sabiendas de que "en los silencios teóricos se sobreimprimen ${ }^{126}$ discursos ideológicos" (EP: 132)- así como sobre su abandono del tratamiento de la ideología desde una teoría materialista de los discursos.

Al leer estas discontinuidades sobre el propio discurso althusseriano surge la posibilidad de dar lugar a la problemática de género. Para ello, atenderemos a algunas perspectivas feministas contemporáneas que al analizar los mecanismos de generización, muestran que en estos ocupan un estatuto central los discursos -entendidos desde su materialidad- sea en el marco del sistema capitalista/patriarcal, del sistema sexo/ género, de la tecnología de género o de la colonialidad de género.

\footnotetext{
${ }^{125}$ Según el propio Althusser, esta práctica de lectura al detenerse en las discontinuidades de un texto: "detecta lo indetectable en el propio texto que lee y lo relaciona con otro texto presente con una ausencia necesaria en el primero" (PLC: 23).

${ }^{126}$ La sobreimpresión es definida en el diccionario español como "la operación que consiste en sustituir las voces originales por otras en una lengua diferente, o bien manteniendo las voces originales y añadiendo por sobreimpresión una traducción escrita del contenido de los diálogos". Encontramos en este término un fuerte vínculo con el término sobredeterminación, definido en el Diccionario de Psicoanálisis de Laplanche y Pontalis, bajo la dirección de Lagache ([1967], 2004) como "elementos inconscientes múltiples que pueden organizarse en secuencias significativas diferentes, cada una de las cuales, a un cierto nivel de interpretación, posee su propia coherencia. Este segundo sentido es el más generalmente admitido" (Laplanche y Pontalis, 2004: 411).
} 


\section{¿De qué lecturas somos culpables?}

Yo me aventuraría a pensar que 'anónimo' quien escribió tantos poemas sin firmarlos, fue a menudo una mujer.

(Virginia Woolf. Una habitación)

La palabra eliminada de la vida: la palabra del idiota, del tonto, del loco, del niño, del moribundo, en parte la palabra de la mujer. (Bajtín, Estética de la creación verbal. Cfr. Volóshinov, El marxismo y la filosofia del lenguaje)

Si de confesar lecturas culpables se trata, cabe señalar que, desde una perspectiva materialista de los discursos, evaluamos como un desliz la afirmación althusseriana de que "los discursos no producen más que efectos de significación (...) y que no ejercen ninguna eficacia sobre objetos reales" (EP: 143). En este sentido, partimos de la premisa de que el discurso es tanto material como social, ya que se encuentra regulado en una coyuntura precisa por una compleja red de relaciones con otros discursos y prácticas, ejerciendo su eficacia sobre objetos reales, en articulación con diversas instancias de la estructura social ${ }^{127}$.

Como hemos señalado, la perspectiva de Pêcheux se inscribe en una teoría materialista de los discursos que, al indagar en las articulaciones entre el discurso y la realidad material, ofrece también una respuesta en torno a la articulación entre la constitución del sujeto y la constitución del significado. Recordemos brevemente que, de acuerdo con su análisis, el sujeto es interpelado/ constituido en la evidencia de la constatación - "que vehiculiza y enmascara la norma identificatoria" (Ibíd.: 141)- bajo la que se normalizan determinados mandatos sociales a través de la costumbre y del uso de significantes, en los que se encuentra "atrapado" el sujeto aun antes de nacer. En este marco, es la ideología la que provee las evidencias por las cuales "cada uno sabe lo que es", enmascarando en la "transparencia del lenguaje", el carácter material del sentido, de las palabras y de los enunciados. De este modo, Pêcheux explica cómo se articulan e imbrican las formaciones ideológicas con las formaciones discursivas ${ }^{128}$.

\footnotetext{
${ }^{127}$ Recordemos que, desde una teoría materialista de los discursos, el discurso es el articulador entre la ideología y el inconsciente.

${ }^{128}$ Mara Glozman señala que el concepto de formaciones discursivas surge como "una nueva posición (ni de la lengua ni del habla), como la posibilidad de explicar el proceso mediante el cual se forman sentidos y relaciones de sentido"; como elemento que, al estar caracterizado constitutivamente por relaciones de antagonismo desigual e imbricado con el concepto althusseriano de formaciones ideológicas- "es un
} 
A modo comparativo y explicativo - puesto que se trata de una demarcación teórica- cabe señalar que, la concepción del lenguaje de Foucault, toma una dirección distinta a la de Pêcheux. En el Orden del discurso (1970) la noción de materialidad discursiva ("el discurso en su realidad material de cosas dichas") alude a la capacidad del discurso de formar los objetos de los que habla. Se configura así el carácter performativo del discurso el que es concebido como material - no porque se inscriba en la realidad social- sino porque "hace" y moldea al decir"

Por otra parte, es desde perspectivas feministas críticas al marxismo que vemos que Althusser lector de Marx, acentúa el carácter anónimo de la estructura social (apropiándose de la tesis de que "el capitalismo es un sistema de puestos vacantes") redoblando el silencio en torno a la desigualdad de género. No pudiendo explicar "por qué son generalmente las mujeres las que hacen el trabajo doméstico y no los hombres" (Rubín, 1986: 101). En este sentido, al realizar una lectura sintomática sobre el equívoco de Althusser, también lo hacemos en torno al marxismo tradicional, cuyas categorías "como el propio capital, son ciegas al sexo" (Hartmann, 1979: 8). Frente a lo cual proponemos analizar - siguiendo la perspectivas de las teóricas feministas críticasla articulación fundamental entre el modo de producción capitalista y el modo de producción patriarcal sobre la que se estructuran nuestras sociedades ${ }^{130}$ para dar cuenta de que el género es una estructura diferencial que se articula con la clase.

En esta dirección, el planteo de esta problemática posibilita no sólo reformular la relación entre clase y género; sino también explicar por qué la función- Träger de un modo de producción no puede desentenderse de la sexuación/ generización de sus individuos. En consecuencia, la lectura crítica sobre los lapsus de Althusser en torno al género implica también una lectura crítica en torno al silencio de Marx respecto del carácter constitutivo de los antagonismos de género en una formación social dada. Colocando a las subjetividades feminizadas en el lugar de "la alteridad respecto al hombre", "reclutándolas al trabajo reproductivo" y obligándolas a responder a

concepto capaz de producir un 'cambio de terreno' en el análisis de las prácticas del lenguaje, un desplazamiento susceptible de intervenir en la lucha (teórica) de clases" (Glozman, 2016: 11).

${ }^{129}$ Desde una perspectiva vinculada al posmarxismo, Eliseo Verón (1987) afirmará que lo que llamamos discurso no es otra cosa que "una configuración espacio- temporal de sentido" (Ibíd.: 127) donde se producen "empalmes múltiples", con lo cual se descarta que en el sentido opere una causalidad lineal y transparente, sino que habría una indeterminación constitutiva del sentido. Lo que tiene fuertes vínculos con el rechazo de Foucault a las concepciones reflexivas del lenguaje, que suponen que el sentido se encuentra ya en las cosas y en "la realidad".

${ }^{130}$ Dado que "la acumulación del capital se acomoda a la estructura social patriarcal y contribuye a perpetuarla" (Hartmann, 1979: 2- 3). 
determinados mandatos sociales. Frente a lo cual, mostraremos que estas críticas en torno a la concepción de la mujer como un dato originario por parte de la estructura económica, ha sido un aporte fundamental para desnaturalizar e indagar en torno a los mecanismos específicos de producción de las subjetividades feminizadas.

\section{El sistema sexo/ género}

Cualquiera que sea el término que utilicemos, lo importante es desarrollar conceptos para describir adecuadamente la organización social de la sexualidad y la reproducción de las convenciones de sexo y de género. Necesitamos continuar el proyecto que Engels abandonó cuando ubicó la subordinación de las mujeres en un proceso dentro del modo de producción.

(Gale Rubín, El tráfico de mujeres)

Gale Rubín en El tráfico de las mujeres. Notas sobre la economía política del sexo [1975 (1986)] postula que se es mujer en la medida en que se funciona como tal en la estructura heterosexual dominante ${ }^{131}$ del sistema sexo/ género. Entendido este último como "el conjunto de disposiciones por el que una sociedad transforma la sexualidad biológica en productos de la actividad humana, y en el cual se satisfacen esas necesidades transformadas" (Rubín, 1986: 97).

Rubín desarrolla importantes vínculos entre las relaciones de poder sexo/género que subordinan a las mujeres con los procesos estructurales del desarrollo capitalista en términos de división sexual del trabajo, reconociendo las jerarquías que se establecen por géneros (no vistas por Marx, quien sólo desarrolla las jerarquías entre varones asalariados). Para ello, recurre a la pregunta de Marx: “¿Qué es un esclavo negro? Un hombre de la raza negra. Sólo se convierte en esclavo en determinadas relaciones sociales". Del mismo modo para Rubín "una mujer es una mujer. Sólo se convierte en doméstica, esposa, mercancía, conejito de playboy, prostituta o dictáfono humano en determinadas relaciones" (ibíd.: 96-97).

Entonces bien, si desde una perspectiva materialista y una ontología relacional, el capital es una relación social dentro de la que el trabajador es una función- soporte para reproducir determinadas condiciones de producción; Rubín sostendrá que el sujetomujer es una función dentro un sistema sexo/género, por el cual se producen cuerpos

\footnotetext{
${ }^{131}$ Judith Butler (1999) reconoce explícitamente que su noción de que la práctica sexual tiene el poder de desestabilizar el género surgió tras leer The Traffic in Women de Gale Rubín; con la que pretendía determinar que la sexualidad normativa consolida el género normativo" (p. 12).
} 
sexuados y se reproducen relaciones específicas entre ellos. La cuestión a indagar es bajo qué mecanismos.

Rubín se pregunta en este sentido: “¿cuáles son esas relaciones en las que una hembra de la especie se convierte en una mujer oprimida?" Para responder a esa pregunta recurre a las obras de Freud y Levi- Strauss, que permiten "vislumbrar un aparato social sistemático que emplea mujeres como materia prima y modela mujeres domesticadas como producto" (Ibíd.: 96). Pero advierte que ni Freud ni Levi- Strauss pudieron tener esta mirada crítica y un ojo feminista; frente a lo cual propone leerlos “como Marx leyó a los economistas políticos clásicos que lo precedieron” (Ídem).

En esa dirección, Rubín hace una lectura sintomática de Freud y de Lévi-Strauss "que no ven precisamente lo que ven"132, que estos mecanismos de identificación/ reconocimiento tienen lugar en: 1) los sistemas de parentesco, objeto de análisis de la antropología estructural que "reproducen formas concretas de sexualidad organizada" (Ibíd.: 107), y que tienen como una de sus modalidades históricas, la del intercambio de mujeres. Ya que, bajo este mecanismo se captura a los individuos y se los inscribe en un sistema organizado dicotómicamente en dos géneros opuestos, y jerarquizados a través de roles que deben asumir; 2) la institución familiar que, a través de vínculos de identificación, especialmente acontecidos en el momento de la "maquinaria edípica" que -entendida por Rubín como una "máquina que modela las formas apropiadas de individuos sexuales" (Ibíd.: 123)- produce sujetos generizados en el binomio varón y mujer. Entre ambos mecanismos, existe -según Rubín- una articulación tal, que el sistema de parentesco formula demandas a las que responde la institución familiar, y que da como resultado el individuo sexuado preparado para "marchar solo" en el sistema estratificado por géneros.

Ahora bien, Rubín advierte que en el análisis de $\operatorname{Marx}^{133}$ de la reproducción de la mano de obra según el cual lo que hace falta para reproducir al trabajador es determinado en parte por las necesidades biológicas del organismo humano, por las

\footnotetext{
${ }^{132}$ Rubín recoge explícitamente la lectura que Marx hace de los economistas clásicos, siguiendo el protocolo de lectura de Althusser y Balibar que desarrollamos en la parte I de este trabajo.

${ }^{133}$ También por aquellos años, Luce Irigaray en "El mercado de las mujeres" [1977 (1982)] utiliza las nociones de la economía política de Marx para teorizar en torno al uso que se ha hecho de los cuerpos femeninos en lo que ella llama "régimen de propiedad paterna" de las sociedades occidentales. Para Colaizzi, las teorías de Marx permiten a Irigaray establecer una conexión entre diferencia sexual y explotación económica, dando una definición de la especificidad femenina y mostrando el funcionamiento de las sociedades patriarcales a partir de sus presupuestos estructurales" (1990: 17).
} 
condiciones físicas del lugar en que vive y por "un elemento histórico y social" que, en el caso de los trabajadores ingleses es la cerveza y para los franceses, el vino- hay una ausencia respecto al lugar fundamental que ocupan las mujeres para garantizar las necesidades básicas que reproducen la fuerza de trabajo (que tengan una cena, un desayuno, ropa limpia, entre muchas otras cosas); y, que garantizan la reproducción del capital. Reponiendo ese silencio, Rubín establece que ese "elemento histórico y social" es la "esposa", aquella encargada del trabajo doméstico, imprescindible para la reproducción de la vida en el marco de las relaciones capitalistas de producción donde "las mujeres no heredan, no dirigen y no hablan con el dios" (Ibíd.: 101).

Desde nuestra perspectiva, evaluamos que, al establecer que ese elemento histórico y social es el que proporcionó al capitalismo una herencia cultural de formas de masculinidad y femineidad, Rubín aporta una respuesta acerca del modo en que las mujeres quedan recluidas a un lugar subordinado respecto al varón, en el aparato familiar y del parentesco. Puesto que, al conceptualizar que un sistema de sexo/género es "el momento reproductivo de un modo de producción" (Ibíd.: 104), Rubín aporta elementos en torno al problema -ausente en los discursos androcéntricos- del modo de producción doméstico y del relegamiento de la mujer al ámbito privado, las tareas del hogar y del cuidado.

Profundizando en la articulación esencial entre la estructura capitalista y la patriarcal, se inscriben las investigaciones de las teóricas feministas de la reproducción, iniciadas en la década de los '60 donde se examinan los efectos nocivos de la división sexual del trabajo sobre las mujeres. Es potente sostener este último término, si acordamos con Ciriza (2007) en que, si bien el significante mujeres ${ }^{134}$ encubre $^{2}$ determinaciones de clase, etnia, nacionalidad, orientación sexual, edad, cultura, lengua; es una herramienta política, si se la comprende de modo no esencialista sino materialista.

\section{La reproducción desde perspectivas feministas críticas}

\footnotetext{
${ }^{134}$ Dice Ciriza: "pienso en "las mujeres" de la misma manera que Marx pensaba la "población" como una categoría inespecífica, una primera aproximación, un punto de partida concreto - abstracto que remite a un vivido, pero no sabido que ha de ser sometido a procesos de destotalización analítica a los fines de ir especificando las determinaciones históricas y sociales. Parafraseándolo y reemplazando podríamos decir que (las mujeres) “... es una abstracción si dejo de lado, por ejemplo, las clases y estas clases son una palabra huera si desconozco los elementos sobre los cuales reposan, por ejemplo, el trabajo asalariado, el capital..." (Cfr. Marx; K., (1857) 1971: 21).
} 
Las circunstancias históricas y económicas de la aparición del capitalismo no plantearon como primordial el problema de la reproducción de la fuerza de trabajo. En realidad, esta reproducción, mediante el proceso de acumulación primitiva del que nació el capitalismo, se encontró resuelta de entrada.

Ni Marx ni los economistas se preocuparon por ella como si fuera un problema

fundamental.

(Claude Meillasoux en Mujeres, graneros y capitales)

¿Guarda Marx silencio sobre el trabajo doméstico porque, como se ha sugerido "no veía fuerzas sociales capaces de transformar el trabajo doméstico en una dirección revolucionaria"?

(Cleaver, Una lectura política de El capital)

En el capítulo XXIV del libro I de El Capital Marx analiza la acumulación originaria (AO) como el proceso histórico de escisión entre productor y medios de producción; mediante el cual, el capital fue concentrándose en pocas manos y se les arrebata a los productores directos los medios de producción. Se trata de un proceso que ocurre de forma violenta -"la historia de esta expropiación de los trabajadores ha sido grabada en los anales de la humanidad con trazos de sangre y fuego"135 - que transforma a los productores directos en trabajadores libres $^{136}$, vendedores de la fuerza de trabajo $^{137}$.

Con este análisis de la AO, Marx logra dar cuenta de que el capitalismo no podría haberse desarrollado sin una concentración previa de capital y de trabajo; y que tampoco podría haberse instaurado sin la separación de los trabajadores de los medios de producción. Sin embargo, su análisis tiene un sesgo androcéntrico, puesto que no

\footnotetext{
${ }^{135}$ Es más que sugerente en este sentido, la propuesta de las feministas descoloniales y anticoloniales que consideran que la AO generada en Europa con la expropiación de tierras y métales en las Américas, corrió paralela a la "violación originaria" mediante la cual se produjo la apropiación de los cuerpos de la mujer indígena o negra. Análisis que son sumamente productivos para leer la $\mathrm{AO}$ en clave situada desde Nuestramérica (Espinosa Miñoso, 2014).

${ }^{136}$ Se trata de trabajadores libres en el doble sentido: en que ni están incluidos directamente entre los medios de producción- ni tampoco les pertenecen a ellos los medios de producción -a la inversa de lo que ocurre con los campesinos que trabajan su propia tierra (Marx, 2004: 892)-. Federici advierte que "Marx no distingue entre trabajadores y trabajadoras en su discusión sobre la liberación de la fuerza de trabajo" (Federici, 2010: 103). Hay otras críticas al enfoque de Marx, como la de Samir Amín quien centra su atención en el eurocentrismo de Marx; mientras que María Mies pone énfasis en la ceguera en relación con la explotación de las mujeres.

${ }^{137}$ Para Marx, al transformar el trabajo en una mercancía, el capitalismo hace que el proceso de trabajo se convierta en un espacio de extrañamiento: el trabajador "sólo se siente en sí fuera del trabajo, y en el trabajo fuera de sí. Está en lo suyo cuando no trabaja y cuando trabaja no está en lo suyo" (ver Marx, 1968).
} 
analiza los efectos que la nueva división sexual del trabajo ejerce sobre las mujeres; y subsidiariamente, no puede ver la reproducción como un trabajo productivo.

Ahora bien, desde una lectura crítica a la de Marx -que sólo examina la AO desde el punto de vista del proletariado asalariado de sexo masculino y del desarrollo de la producción de mercancías- las investigaciones iniciadas en la década de los '60 por las teóricas feministas de la reproducción, examinan los efectos nocivos de la división sexual del trabajo sobre las mujeres. En esta línea de análisis, El Calibán y la bruja [(2004), 2010 $]^{138}$ de Silvia Federici examina la AO desde el punto de vista de los cambios que introduce en "la posición social de las mujeres y en la producción de la fuerza de trabajo" (Federici, 2010: 19-20).

Para ello, la pensadora feminista incluye una serie de fenómenos que están ausentes en el análisis de Marx: 1) el desarrollo de una nueva división sexual del trabajo que somete el trabajo femenino y la función reproductiva de las mujeres a la reproducción de la fuerza de trabajo; 2) la construcción de un nuevo orden patriarcal basado en la exclusión de las mujeres del trabajo asalariado y su subordinación a los hombres; 3) la mecanización del cuerpo proletario y su transformación, en el caso de las mujeres como máquinas reproductoras de fuerza de trabajo.

En este sentido, lo que propone la lectura crítica de Federici es hacer visible la historia subterránea de las mujeres en la transición del feudalismo al capitalismo, retomando las investigaciones de Mariarosa Dalla Cosa, Selma James y María Mies, quienes examinan que la explotación de las mujeres había tenido una función fundamental en el proceso de acumulación capitalista; dado que las mujeres habían sido las productoras y reproductoras de la mercancía capitalista más esencial: la fuerza de trabajo (Cielo y Vega, 2015). El trabajo reproductivo desde las teorías feministas de la reproducción es comprendido entonces, como esencial para reproducir la mano de obra, en última instancia, al capital, pero invisibilizado en el análisis de Marx y Engels. Con lo cual, estas teóricas feministas logran mostrar que el trabajo gratuito de las mujeres en sus hogares se constituyó en el pilar de la explotación capitalista.

Desde este marco, se examina que mientras que el trabajo productivo tiene como resultado la producción de mercancías y de bienes de cambio; el trabajo reproductivo,

\footnotetext{
${ }^{138}$ Se trata de la conclusión de las líneas centrales de un proyecto de investigación que comienza a mediados de los '70, en colaboración con la feminista italiana Leopoldina Fortunati, cuyos primeros resultados aparecieron en 1984 en el libro: El gran Calibán. Historia del cuerpo social rebelde en la primera fase del capital.
} 
produce bienes de uso, destinados a garantizar las necesidades básicas que "sostienen" la vida cotidiana y permiten reproducir la mano de obra. Por otra parte, mientras que el primero se desarrolla en el espacio público como las fábricas ${ }^{139}$, y es remunerado mediante un salario; el segundo, se desarrolla en el espacio privado de los hogares y es gratuito.

A modo comparativo, cabe señalar que Immanuel Wallerstein (1988) argumenta en El capital histórico que fue en el contexto de esta estructura de unidades domésticas donde empieza a imponerse a las clases trabajadoras la distinción social entre trabajo productivo y trabajo improductivo. De hecho, señala Wallerstein, el trabajo productivo comienza a ser pensado como un trabajo que devengaba un salario y el trabajo improductivo, era pensado meramente como una actividad de subsistencia, y que, por tanto, "no producía un excedente del que pudiera apropiarse alguien" (Wallerstein, 1988: 14- 15). En este marco, mientras que el trabajo productivo era realizado fuera de la unidad doméstica, en "el centro de trabajo" por parte de un varón asalariado mayor de edad; el trabajo no productivo era realizado dentro de la unidad doméstica, de manera gratuita por una mujer.

Ahora bien, desde una perspectiva feminista materialista Christine Delphy (1985) señala que existe un modo de producción doméstico que está ausente en el análisis de Marx y que es precondición de la riqueza del sistema capitalista. Se trata del trabajo doméstico - un trabajo no remunerado y no intercambiable en el mercado- que la clase "esposas" le cede a la clase "esposos" mediante el contrato matrimonial. Delphy utiliza el término doble invisibilización de las mujeres (de la situación de las mujeres, de su trabajo y su explotación) para referir al no planteamiento de la división sexual del trabajo en el análisis del capital de Marx, lo que constituye una obturación y un problema, que impide al materialismo histórico analizar "las relaciones específicas de las mujeres con la producción" (Delphy, 1985: 11). Según Delphy, es a causa de esta limitación, que las mujeres son subsumidas a la clase proletaria, mientras que estas mantienen una relación específica con la producción -similar a la servidumbre- ya que su trabajo es explotado dentro de la unidad familiar. Para ella, son "esas relaciones de producción las que explican que sus trabajos se vean excluidos del mundo del valor"

\footnotetext{
${ }^{139}$ Federici señala: "el movimiento anticolonialista nos enseñó a ampliar el análisis marxista sobre el trabajo no asalariado más allá de los confines de la fábrica y así, contemplar el trabajo doméstico como el cimiento del trabajo fabril (...)" (Federici, 2013: 23).
} 
(ibíd.: 14). Es decir que, son las mujeres (no su producción) las que son excluidas del mercado, en tanto agentes económicos.

Tanto el feminismo marxista $(\mathrm{u}$ obrerista) como el feminismo materialista ofrecen argumentos para demostrar que el trabajo doméstico es un trabajo productivo, que produce no sólo valores de uso sino también valores de cambio. Puesto que toda una serie de servicios garantizados por el trabajo doméstico -como hacer la comida (que podría ser vendida como en un restaurant), lavar la ropa (como lo hacen los servicios de lavandería o de limpieza); el cuidado de los niños, el de ancianos ${ }^{140}$ - si no se desarrollaran en el hogar pueden ser "abiertamente producidos e intercambiados como mercancías" (Arruzza, 2010: 108). Lo cual demuestra que la naturaleza del trabajo doméstico es también de carácter productivo, pero al estar investido por su gratuidad (aparente gratuidad) queda asociado como mera reproducción.

Ahora bien, aunque ambas corrientes acuerdan en su diagnóstico del trabajo doméstico y de los cuidados como trabajos productivos y reproductivos, proponen tareas políticas diferentes. Desde el enfoque del feminismo marxista se identifica que "las mujeres sufren la misma explotación que los hombres y, por consiguiente, comparten con ellos un enemigo principal: el capitalismo" (Ibíd.: 113). En consecuencia, como trabajadoras su lucha política debía estar signada por la reivindicación del salario para las amas de casa. Lo que condujo a la organización de la campaña internacional "Salario para el trabajo doméstico (WfH, sus siglas en inglés)"141 para que el Estado reconociera el trabajo reproductivo también como productivo, por tanto, pasible de ser remunerado. La campaña se proponía visibilizar el trabajo crucial de las mujeres en sus hogares, un trabajo no reconocido; pero, sin embargo, del que el capitalismo dependía para contener y reproducir la mano de obra. Y, además, se proponía mostrar que este trabajo era una de las herramientas de disciplinamiento más importantes por su anclaje al salario, y porque se trataba de un modo de producción de

\footnotetext{
140 Una discusión aparte merece aquella centrada en la valorización del trabajo sexual, puesto que constituye una frondosa polémica que aun en los feminismos actuales divide posiciones entre las denominadas abolicionistas y no abolicionistas.

${ }^{141}$ Federici señala que en 1972 se unió a esta organización que nucleó corrientes políticas de diferentes partes del planeta y de diversos sectores del mundo proletario, "las mujeres que impulsaron WfH venían de una historia de militancia en organizaciones que se identificaban como marxistas, marcadas por su participación en los movimientos anticoloniales, el Movimiento por los Derechos Civiles, el movimiento estudiantil y el movimiento operaista. Este último se había desarrollado en Italia a principios de la década de los sesenta como resultado del resurgimiento de las luchas obreras en las fábricas, y condujo a una crítica radical del 'comunismo' y a una relectura de la obra de Marx (...)” (Federici, 2013: 22- 23).
} 
la subjetividad y de lazos sociales que posibilitaban la continuidad del sistema capitalista.

Mientras que, para las feministas materialistas si bien "el capitalismo contribuye ciertamente a mantener con vida el modo de producción patriarcal a través de sus mecanismos de exclusión de las mujeres del mundo productivo y de jerarquización de la fuerza de trabajo" (Ibíd.: 110-111); el "enemigo principal" es el patriarcado. En este marco, se comprende que la explotación de "las mujeres"142 se encuentra vinculada a su pertenencia como miembros de una misma clase: la clase mujeres que se encuentran en una situación de esclavitud en relación a los hombres, los beneficiarios directos de la opresión de las mujeres. En consecuencia, esta corriente hace un llamado a las mujeres a tomar conciencia e identificarse con su clase y no con la de su marido, que independientemente de la actividad laboral que desarrolle, sacará algún provecho explotando a su esposa.

También las feministas radicales ubican que el enemigo principal es el patriarcado, pero lo abordan no centrándose en la producción y en las relaciones de clase, sino en el carácter político del sexo. En esta línea, por ejemplo Kate Millet en Política sexual (1970) afirma que, la opresión sexual es la forma de dominio político central, que precede y estructura a las demás opresiones; con las que sin embargo, puede articularse, como el racismo ${ }^{143}$. En efecto, lo que proponen las feministas radicales es, no transformar al género en clase; sino más bien postular al género sin clase e indagar centralmente en torno al estatuto del sexo. De allí que para Rubín el género sea una división de los sexos socialmente impuesta: "un producto de las relaciones sociales de sexualidad" (Rubín, 1986: 114), que opera como "chaleco de fuerza".

Cabe señalar por otra parte, que estas distinciones entre corrientes teóricas no son estrictas ni rígidas, sino que se encuentran enlazadas e imbricadas. En este sentido,

\footnotetext{
${ }^{142}$ Esta pretensión universalista de un feminismo hegemónico, es criticado desde el margen, es decir, por las otras del feminismo blanco, burgués, formado; que, al disolver la clase, y también la etnia/ raza, en el género, termina por invisibilizar y anular otras opresiones. Frente a lo cual argumentamos que el planteo en términos de jerarquías entre explotaciones y opresiones, es limitado ya que impide ver las intersecciones e imbricaciones que existen entre las diversas determinaciones en cuanto a sexo/ género, clase, raza/ etnia, edad. Puesto que, los análisis interseccionales ponen de manifiesto dos asuntos: en primer lugar, la multiplicidad de experiencias de sexismo vividas por distintas mujeres, y en segundo lugar, la existencia de posiciones sociales que no padecen ni la marginación ni la discriminación (Vigoya, 2016).

143 Para Cháneton (2004): "adelantándose en mucho a los estudios post- culturales y los Estudios Culturales que abordan en los años '90, la cuestión de 'lo negro"” (p. 40).
} 
Hartmann, por ejemplo -influenciada por las feministas radicales- afirma que no basta con examinar la naturaleza de la opresión de las mujeres en cuanto que trabajadoras; es decir desde el marco del capitalismo (un sistema que crea posiciones de sujeto, pero no explica concretamente quiénes son esos sujetos). Sino que es necesario indagar en la opresión de las mujeres desde el marco del patriarcado, que permite salir del anonimato y definir los quiénes que ocuparán esas funciones de la estructura económica. Es desde estas coordenadas que la autora de Un matrimonio infeliz entre Marxismo $y$ Feminismo...comprende que la importancia del trabajo doméstico como relación social, es que perpetúa la estructura del patriarcado. Y por ello critica a Dalla Costa que, en su reivindicación del salario doméstico, no tendría como punto de partida las relaciones entre el hombre y la mujer; sino que "utiliza la concepción feminista del trabajo doméstico como un trabajo real para reivindicar su legitimidad bajo el capitalismo, afirmando que debería ser un trabajo asalariado" (Arruzza, 2010: 6).

Bajo nuestra perspectiva, consideramos que si bien, en algún punto la reivindicación del salario para la ama de casa, refuerza el rol de la mujer como cuidadora y trabajadora doméstica (como critica Hartmann); logra dar una respuesta en torno a la naturaleza material de la opresión de la mujer, abordando con autonomía la “cuestión de género", que se encontraba relegada a la explotación de la clase proletaria en el marco del marxismo tradicional. En este sentido, Federici señala que si bien "pocos analistas políticos han descrito la brutalidad del trabajo capitalista de manera tan descarnada como Marx" (Federici, 2018: 50), existe un silencio teórico en torno al género; cuestión que en el Libro I de El capital -donde Marx la abordaría por primera vez- es abordada no en el marco del proyecto capitalista patriarcal de la familia burguesa, sino en lo que respecta a las condiciones de trabajo de las mujeres en las fábricas durante la Revolución Industrial.

Marx, según Federici, elude explicar cómo afectó el ingreso de las mujeres en las fábricas la relación entre los sexos. Lo que sí hay, según la autora, es el recurso por parte de Marx a comentarios moralistas al señalar que este ingreso implicó una "degradación moral"; así como favoreció un comportamiento "promiscuo" en las mujeres que las llevó a descuidar sus obligaciones maternales (Cfr. Ibíd.: 51). Más aún para Federici: “(Marx) casi nunca representa a las mujeres como figuras capaces de luchar por sí mismas. Casi siempre aparecen como víctimas, aunque sus contemporáneas señalaran su independencia, su comportamiento guerrero y su 
capacidad para defender sus intereses frente a los propietarios de las fábricas" (Seccombe, 1993: 121. Cfr. Ídem) ${ }^{144}$.

En efecto, desde la perspectiva crítica de Federici, la "cuestión del género" es marginal en el extensísimo El capital donde Marx, en ningún momento reconoce que la reproducción de la fuerza de trabajo implica el trabajo doméstico no pagado de las mujeres, sino más bien habría una autorreproducción por parte del asalariado ya que "el valor de la fuerza de trabajo es el valor de los medios de subsistencia necesarios para la conservación del poseedor de aquella" (Federici, 2018: 57). Incluso cuando se refiere a la reproducción general de la mano de obra, Marx no menciona la contribución de las mujeres y descarta la posibilidad de que estas puedan tomar decisiones autónomas en temas de procreación. Sin embargo, Federici modera su crítica hacia Marx y afirma que tiene sospechas de que la indiferencia de este en torno al trabajo reproductivo puede estar vinculada al hecho de que "en el momento histórico en el que Marx escribió su obra, la familia nuclear ${ }^{145}$ y el trabajo doméstico no estaban todavía desarrollados" (Ibíd.: 33). Mientras que, por ejemplo, desde perspectivas ecofeministas como la de Ariel Salleh (1997) habría una conexión entre el desdén por parte de Marx hacia el trabajo doméstico, la desvalorización de la naturaleza y la idealización de todo lo que produce la industria.

Pero los equívocos, silencios y discontinuidades en torno al género, no sólo ha sido característica de la tradición marxista, sino que se encuentra también, por ejemplo, al final del Tratado político de Spinoza, el que es interrumpido hasta quedar inconcluso en el punto exacto en el que el autor comete un equívoco. Luego de afirmar que las mujeres no pueden ser excluidas por razones legales - ("Más quizás alguno se pregunte si acaso las mujeres están bajo la potestad de los hombres por naturaleza o por ley. Ya que, si ese hecho solo se fundara en una ley, ninguna razón nos forzaría a excluirlas del gobierno")- Spinoza argumenta que las mujeres son excluidas por su naturaleza, ya que tienen la capacidad de afectar a los hombres; los que "si estuvieran regidos por las mujeres serían criados de manera que no pudieran hacer uso completo de sus habilidades" (TP, XI, 4).

\footnotetext{
144 Segato sostiene en este sentido que existe una frondosa narrativa que representa a la mujer como vencida, dominada y disciplinada, no sólo en el relato bíblico del Génesis, sino en toda una serie de "mitos dispersos en todos los continentes, Xerente, Ona, Baruya, Masai, etc., incluyendo el enunciado lacaniano de un falo que es femenino, pero que el hombre 'tiene', leído en clave de mito, nos hablan aquí de un evento fundacional" (Segato, 2016: 19).

145 Por familia nuclear debe entenderse al modelo de organización microeconómica del capitalismo heteropatriarcal.
} 
El recurso de Spinoza a la naturaleza de las mujeres capaz de afectar la plena racionalidad de los hombres, constituye un desliz respecto a su tesis de que "los hombres están sujetos a todo tipo de pasiones que no obtura su posibilidad de conformar un cuerpo político" (Vacarezza, 2010: 1). No podemos seguir indagando en el lapsus de Spinoza, aunque nos interesa plantear su recurso a un discurso naturalista para limitar y excluir a las mujeres del derecho político y de la participación del gobierno. Esta ideología naturalista se encuentra en la base de diversas prácticas y discursos que establecen órdenes jerárquicos de acuerdo a procesos de generización y racialización.

Ahora bien, para nosotros la lectura de Federici es potente porque permite trazar líneas de investigación en torno a la naturaleza material de la opresión de las mujeres a partir de su confinamiento al trabajo doméstico. Un trabajo que las mujeres realizan en sus hogares de manera "invisible" y no remunerada- formulando una pregunta no planteada “¿Cuándo y cómo comienza toda esa historia?”

\section{Los efectos materiales de los discursos en la guerra contra las mujeres}

De cintura para abajo son centauros, aunque sean mujeres arriba. Hasta el talle gobiernan los dioses; hacia abajo los demonios. Ahi está el infierno, las tinieblas, el pozo sulfúreo, ardiendo, quemando; peste podredumbre

(Shakespeare, Rey Lear)

Marx se enfrentó a la historia del desarrollo del capitalismo en Europa, en el mundo, desde el punto de vista de la formación del trabajador industrial asalariado, de la fábrica, de la producción de mercancías y el sistema del salario, mientras que obvió problemáticas luego cruciales en la teoría y la práctica feminista: toda la esfera de las actividades centrales para la reproducción de nuestra vida, como el trabajo doméstico, la sexualidad, la procreación. (Federici, El patriarcado del salario)

Al investigar las condiciones sociales e históricas de la $\mathrm{AO}$ desde el punto de vista de las mujeres, Federici advierte que el cuerpo $^{146}$ se convierte en un elemento central para la acumulación de capital. Y en el caso de los cuerpos de las mujeres, se trata de su principal terreno de explotación, así como "la fábrica lo es para los asalariados varones" (Federici, 2010: 28). Federici afirma que en el proceso de instauración capitalista el estatuto del cuerpo no es el del margen, sino que adquiere

${ }^{146}$ El análisis de Federici es doblemente potente ya que al plantear la cuestión de las subjetividades con género desde una perspectiva materialista interseccional, permite dar cuenta de que el reconocimiento de subjetividades con género implica reconocer a su vez la cuestión de los cuerpos sexuados. 
centralidad, dado que la representación de las mujeres como sinónimo de naturaleza e identificadas con la corporalidad (Ibíd.: 27) posibilitó las condiciones para que sean reclutadas al ámbito privado, al trabajo doméstico y a la familia ${ }^{147}$. En esta dirección, Federici argumenta que, en el marco de la modernidad capitalista, el cuerpo -escindido completamente de la mente- era identificado con la naturaleza, con la que compartiría los mismos elementos y las mismas leyes físicas; pero, además, el cuerpo -concebido puramente como materia inerte- era descrito por analogía con el objeto- máquina. De allí que en este escenario los intelectuales se preguntaran: “¿Puede el cuerpo pensar?”.

En la literatura de la época, por ejemplo, en el Acto I de La tempestad de Shakespeare, se hace referencia al cuerpo como productor de la fuerza de trabajo, como la fuente principal de acumulación de capital. Por ello -según Federici- la burguesía emergente intentó adecuar las clases subordinadas a las necesidades de desarrollo de la economía capitalista, creando un nuevo tipo de individuo. Ha sido, según la autora, bajo la pretensión de crear un sujeto capitalista que la burguesía entabló una batalla contra el cuerpo que se convirtió en su impronta histórica, y en la marca del nuevo espíritu burgués que "calcula, clasifica, hace distinciones y degrada al cuerpo sólo para racionalizar sus facultades, lo que apunta no sólo a intensificar su sujeción, sino a maximizar su utilidad social (Ibíd.: 224).

Lo cual explica por qué en las estrategias que adoptó el Estado hacia el cuerpo haya además de violencia correctiva, mucho interés. En este sentido, Federici señala que en la reforma del cuerpo que está en el corazón de la ética burguesa de Max Weber -por ejemplo- se manifiesta que el capitalismo hace de la posesión "el objetivo final de la vida"148 en lugar de tratarla como medio para satisfacer las necesidades humanas. En este marco, tanto la pérdida como la superación del "estado natural" se vincula estrechamente con el interés del proyecto capitalista de "romper las barreras de la naturaleza" al extender el día de trabajo todo lo posible; tal como advierte Marx en los Manuscritos de 1844 en su análisis en torno al "trabajo alienado". Puesto que, el

\footnotetext{
147 La familia funcional al capitalismo heteropatriarcal es para Pérez Orozco, la familia nuclear (matrimonio heterosexual, más hijxs) ya que opera como organización microeconómica de este sistema general. De manera análoga, para Federici, la familia constituye "la institucionalización de nuestro trabajo no remunerado, de nuestra dependencia salarial de los hombres $\mathrm{y}$, consecuentemente, la institucionalización de la desigualdad división de poder que ha disciplinado tanto nuestras vidas como la de los hombres" (Federici, 2018: 34).

${ }^{148}$ Por eso es que el tipo de vida en las sociedades capitalistas es una vida alienada ya que, por una parte, los poseedores tienen una aparente existencia humana, mientras que los desposeídos tienen una vida humana indigna (Pavón Cuellar, 2014: 233-239).
} 
objetivo de la sociedad capitalista es transformar la vida en capacidad para trabajar, y en "trabajo muerto".

Así las cosas, para que el proyecto político capitalista fuese instaurado era necesario erradicar del proletariado cualquier comportamiento que no condujera a la imposición de una disciplina de trabajo más estricta (al decir de Foucault, el "disciplinamiento del cuerpo" puede ser pensado como el intento del Estado de transformar las potencias del individuo en fuerzas de trabajo ${ }^{149}$ ). Es por ello, según Federici, que el estudio de los movimientos y propiedades del cuerpo se convirtió en el punto de partida para buena parte de la especulación teórica de la época, ya sea para afirmar la inmortalidad del alma (Descartes); o para investigar las premisas de la gobernabilidad social (Hobbes).

En efecto, el cuerpo en el periodo de instauración de la modernidad capitalista se constituyó en parte central de las políticas públicas porque aparecía no sólo como una "bestia inerte" ante los estímulos del trabajo, sino como un recipiente de fuerza de trabajo, un medio de producción: la máquina de trabajo primaria. A esto hay que agregarle, que en un sistema donde la vida está subordinada a la producción de ganancias, la acumulación de la fuerza de trabajo sólo puede lograrse con el máximo de violencia, para que la violencia misma se transforme en la fuerza más productiva. A diferencia de Marx, Federici afirma que cada fase de la globalización "ha venido acompañada de un retorno a los aspectos más violentos de la acumulación originaria" (Ibíd.: 30).

En este marco, Federici sitúa la emergencia del reclutamiento de la mujer al trabajo doméstico en el periodo de transición del feudalismo al capitalismo, un proceso que no fue natural sino violento, y que requirió formas precisas de organizar y domesticar el trabajo y la vida. El trabajo doméstico -producto de la nueva división sexual del trabajo- se constituye así, desde esta línea de análisis, en una precondición para la acumulación del capital, motivo por el cual "era necesario antes desposeer a las mujeres de su propio cuerpo y de todos los saberes propios de una sociedad ginocéntrica" (Cielo y Vega, 2015: 134).

\footnotetext{
${ }^{149}$ Federici también denuncia el androcentrismo de Foucault en sus teorizaciones sobre la tecnología del sexo y sobre el castigo sobre los cuerpos: "hubiera estudiado la caza de brujas en lugar de concentrarse en la confesión pastoral, es que es historia no puede escribirse desde el punto de vista de un sujeto universal, abstracto y asexual" (2010: 31).
} 
Es este proceso de desposesión y de guerra contra las mujeres el que explora Federici en El Calibán y la bruja...y lo hace colocando el foco en la bruja, aquella que en La tempestad de Shakespeare tiene un lugar secundario, pero paradójicamente está en el centro de los ataques de los detentores del capital. Federici comprende así, la cacería de brujas como un acontecimiento fundacional en el proceso de instauración del capitalismo a comienzos de la era moderna, el que surge "mientras esta guerra contra las mujeres está en marcha" (Federici, 2010: 23) y que sirvió para allanar el camino al desarrollo de un régimen patriarcal más opresivo ${ }^{150}$.

Bajo esta lectura crítica, la persecución de miles de brujas en el medioevo es fundamental para el establecimiento del control del Estado sobre los cuerpos de las mujeres- reproductoras de fuerza de trabajo; y para garantizar que estas ocuparan el lugar de "sirvientas" de la fuerza de trabajo masculina. Leer el carácter necesario de este acontecimiento histórico, permite comprender que el trabajo femenino se convirtió en un recurso natural disponible: las mujeres se constituyeron en bienes comunes y fueron "obligadas" a ocuparse de la reproducción de la vida.

Lo que nos interesa destacar, puesto que se trata de uno de los objetivos del capítulo, es que Federici les otorga a los discursos de la época en el estatuto de factores centrales en la legitimación de la violencia contra las mujeres. Su argumento se centra en exhibir que, en la mayoría de las construcciones discursivas de la época, se representaba a las mujeres como "bestialmente sexuales", "pasionales" -al ser identificadas con la naturaleza y con "lo corporal"- lo que ha dado lugar a que sean comprendidas como alteridad, inferiores e irracionales; que necesariamente debían ser colocadas bajo el control de los hombres y del Estado.

Efectivamente, Federici advierte que los discursos de la época demonizan y degradan a las mujeres representándolas como "carentes de racionalidad", "excesivamente emocionales", "lujuriosas" e "incapaces de manejarse por sí mismas", además de "vanidosas", "salvajes", “despilfarradoras", "regañonas”, entre otras cosas" (Ibíd.: 180). Lo sintomático es que, cuando se instaura el capitalismo, el discurso sobre estas cambia, revelando que las mujeres pudieron ser "domesticadas" gracias a un proceso de degradación social. Si antes estas eran consideradas como irracionales y

${ }^{150}$ Para Segato el patriarcado es la estructura política más arcaica y permanente de la humanidad, que moldea la relación entre posiciones y precede a la era colonial- moderna. En esta línea sostiene que "la conquista misma hubiera sido una empresa imposible sin la preexistencia de ese patriarcado de baja intensidad, que torna a los hombres dóciles al mandato de masculinidad" (Segato, 2016: 19) y que coloca a la mujer como vencida y disciplinada, es decir, en una posición de subordinación y obediencia. 
bestiales, una vez instaurado el sistema capitalista, se las describe como "obedientes", "sumisas", "capaces de apaciguar a los hombres", "maternales por naturaleza", etc.

En consecuencia, el trabajo doméstico realizado por las mujeres también ha sido naturalizado $^{151} \sin$ necesidad de contratos, regulaciones, ni leyes, bajo el supuesto de su predisposición natural a las tareas domésticas y a los cuidados -es decir, a las actividades que cubren los espacios que los mercados dejan vacíos por ser no rentables y por ello mismo son no reconocidos.

Además, los cuidados implican una moral conservadora en la que, bajo el supuesto amor hacia los demás, se justificaría el sacrificio de las mujeres para cuidar de los otros; ocultando la imposición de la lógica de acumulación capitalista. Es por ello que desde perspectivas críticas se advierte que esta "ética del cuidado" es reaccionaria en un triple sentido: "porque es una ética de inmolación y sacrificio que da lugar a sujetos dañados; porque sólo se preocupa por el bienestar en los estrechos márgenes de la familia; y porque sirve para acallar el conflicto capital- vida" (Pérez Orozco, 2014: $171)^{152}$. Las tareas del cuidado son fundamentales para sostener la vida, pero no son reconocidas, sino ocultadas, con lo cual "acallan" las contradicciones de un sistema basado en la desigualdad. En esta dirección se torna plausible que "cumplir adecuadamente la labor de cuidadora es un elemento fundamental en la construcción del género" (Pérez Orozco, 2014: 92). De allí el riesgo de idealizar los cuidados $^{153}$ al contraponerlos a las actividades reguladas por el mercado ("mientras que el capital destruye la vida, los cuidados la garantizan"); lo que tiene como efecto que estos sean esencializados como naturalmente inherentes a la femineidad ${ }^{154}$.

\section{Ideología de la femineidad y persuasión discursiva}

\footnotetext{
${ }^{151}$ En esta línea, Ciriza señala que existía el trabajo femenino asalariado, en menor escala, considerado como excepcional y "sellado por la inestabilidad" (1994: 44).

${ }^{152}$ De acuerdo con Dolores Juliano (2002) el estigma de la "puta" ha funcionado, históricamente, como mecanismo de control para todas las mujeres, "siempre bajo sospecha de si hacemos cosas por algo distinto al amor" (Cfr. Pérez Orozco, 2014: 169).

${ }^{153}$ La complejidad para rotular a los cuidados, hace que puedan ser emparentados con los monstruos de Haraway: conceptos que se sitúan en fronteras conceptuales, analíticas y políticas, y permiten pensarlas. Ya que si, por un lado, permite avanzar en discusiones en torno a lo público y lo privado, lo afectivo de lo meramente laboral. Por otra parte, se ha exhibido un desgaste del uso del término que "al ser todo, es nada a la vez" (Pérez Orozco, 2014: 93).

154 Atendiendo a estas críticas, Pérez Orozco opta por utilizar la expresión "sostenibilidad de la vida", combinando diversos modos de referencia para los trabajos invisibilizados (trabajos no remunerados, trabajos residuales, de reproducción).
} 
las fórmulas de la canción popular habitual demandaban representaciones no sexuales, empalagosas e idealizadas de las relaciones de amor heterosexuales. Esos aspectos de las relaciones amorosas vividas, incompatibles con la ideología dominante y etérea del amor (como las relaciones extra matrimoniales, la violencia doméstica o lo efimero de muchas relaciones sexuales) eran, en gran medida, desterradas de la cultura musical popular oficial. (Angela Davis en "I Used to Be Your Sweet Mama: Ideologia, sexualidad y domesticidad")

Desde los puntos de vista social, económico, cultural y político la caza de brujas, así como el control de la natalidad y la intervención del Estado para disciplinar los cuerpos feminizados, fue un momento decisivo en la vida de las mujeres; similar según Federici (2010) a la derrota histórica a la que alude Engels en El origen de la familia, la propiedad privada y el Estado como la causa del desmoronamiento del mundo matriarcal ${ }^{155}$. A partir de esta brutal matanza se crean las condiciones materiales para la nueva división sexual del trabajo y de las nuevas relaciones de producción que reclutaron a las mujeres al trabajo doméstico realizado de manera gratuita en el espacio íntimo del hogar -a pesar de que implica actividades cruciales para reproducir y mantener la vida- bajo una supuesta naturaleza femenina que liga a las mujeres con estas tareas.

La nueva división sexual del trabajo es comprendida desde perspectivas críticas del patriarcado como constitutiva de la matriz heteropatriarcal que se encuentra en la base de la familia nuclear y en el proceso de reproducción de su fuerza de trabajo y en el proceso de reproducción social del capital" (Arruzza, 2010: 133). De allí lo acertado de comprender la imposición de la heterosexualidad como parte de la estructura económica, y no como lo "meramente cultural” (Cfr. Wittig, 2006; Rich, 1999).

\footnotetext{
155 Cinzia Arruzza, argumenta que la afirmación de comunidades matriarcales involucra un mito y un equívoco por parte de Engels debido a la escasez de investigaciones y de material etnográfico disponibles por aquel entonces. Engels se habría basado en Bachofen y su teoría de un matriarcado originario, ulteriormente reemplazado por un patriarcado; y ligaba la "derrota histórica de las mujeres" a la afirmación de la propiedad privada individual (en reemplazo de la de la gens), y al paso al matrimonio monogámico (en reemplazo de los matrimonios colectivos). Sin embargo, Arruzza señala que, desde estudios antropológicos actualizados, se revela que en realidad los orígenes de la opresión femenina se encuentran en el paso de las sociedades a la patrilocalidad, interrelacionando así, opresión económica y opresión sexual. Para ampliar: Arruzza, 2010: 97- 101.
} 
Entonces bien, la nueva división sexual del trabajo como constitutiva de la matriz heteropatriarcal, diferenció no sólo las tareas que las mujeres debían realizar, sino también sus experiencias, sus proyectos de vida, sus posibilidades, sus deseos. Para ello, los discursos naturalistas han ocupado un rol central para que las subjetividades feminizadas ocuparan su rol de madres, de esposas, de hacedoras domésticas, de "sostén" de la familia (el aparato ideológico de Estado fundamental) y para que estas pudieran ser reclutadas al trabajo doméstico y reproductivo. El discurso ideológico y el mandato de género durante el proceso de constitución del capitalismo fueron efectivos en la medida en que lograron "sujetar" a las mujeres a las actividades domésticas que el sistema requería por parte de ellas: constituyéndolas como reproductoras, por un lado; y como no trabajadoras, por otro. No sorprende entonces que el matrimonio se presentara como "la verdadera carrera para una mujer" (Federici, 2010: 167) y que la maternidad se haya calificado como una experiencia femenina ineludible, valorada por encima de cualquier otra.

En este escenario quienes se animaban a trabajar fuera de sus casas eran consideradas "brujas" y "arpías" que intentaban subvertir el orden establecido. En realidad, se constituían en prostitutas y sirvientas a la vez, ya que "por más empobrecidos y carentes de poder que estuvieran los trabajadores varones, todavía podían beneficiarse del trabajo o del ingreso de sus esposas, o acudir a una prostituta" (Ibíd.: 178). Federici examina que durante la primera fase de proletarización la prostituta era quien a menudo realizaba el rol de esposas, limpiando y cocinando para los trabajadores varones, además de servirles sexualmente. En consecuencia, la criminalización de la prostitución no perjudicó a los masculinos, sino que acrecentó su poder ya que "cualquier hombre podía ahora destruir a una mujer declarando simplemente que ella era una prostituta o haciendo público que ella había cedido a los deseos sexuales del hombre" (Ídem). De manera que la vida de las mujeres, su dignidad y su "honor", comenzaron a depender de los hombres "que, como señores feudales, podían ejercer sobre ellas un poder de vida o muerte" (Ídem).

Simultáneamente, se legalizó la violación "lo que creó un clima intensamente misógino que degradó a todas las mujeres cualquiera que fuera su clase" pues "una vez violadas no les era fácil recuperar su lugar en la sociedad" (Ibíd.: 92). De esta manera, Federici refuerza su argumento de que las mujeres no hubieran podido ser devaluadas e invisibilizadas como trabajadoras, y privadas de toda autonomía con respecto a los hombres, de no haber sido sometidas a un intenso proceso de degradación social, en el 
que cooperaron tanto humanistas, reformadores, protestantes o católicos de la Contrarreforma. Sus construcciones discursivas no sólo degradaban a las mujeres, sino que también dejaba un mensaje de violencia disciplinadora hacia la "rebelde", como da cuenta la siguiente cita:

.... La fierecilla domada (1593) de Shakespeare era un manifiesto de la época. El castigo de la insubordinación femenina a la autoridad patriarcal fue evocado y celebrado en incontables obras de teatro y tratados breves. La literatura inglesa de los periodos isabelino y jacobino se dio un festín en esos temas. Típica del género es Lástima que sea una puta (1633) de John Ford, que termina con el asesinato, la ejecución y el homicidio aleccionadores de tres de las cuatro protagonistas femeninas... ${ }^{156}$

(Federici, 2010: 181).

En este proceso de degradación social, fue cómplice y responsable el Estado que, mediante la introducción de leyes y nuevas formas de tortura, logró controlar el comportamiento de las mujeres dentro y fuera del ámbito doméstico. Tal es así que, por ejemplo, durante los siglos XVI y XVII, en un contexto de creciente misoginia, al mismo tiempo que la población caía y se formaba una ideología que ponía énfasis en la centralidad del trabajo en la vida económica, se introdujeron sanciones severas en los códigos legales europeos destinadas a castigar a las mujeres culpables de crímenes reproductivos. Es así que, se legalizó la violación (Ibíd.: 169) así como se radicalizó el proceso condenatorio por infanticio, y por delitos reproductivos (Ibíd.: 159) para controlar la natalidad. De manera análoga, en las colonias españolas se dictaron leyes bajo las cuales las mujeres casadas se convirtieron en propiedad de los hombres y se creó todo un sistema de creencias y de valores, como el compadrazgo que le otorgaba mayor poder a los hombres sobre los niños y que limitaba aún más "el poder femenino".

\footnotetext{
${ }^{156}$ Otras obras clásicas que trataban el disciplinamiento de las mujeres son La comparecencia de mujeres indecentes, ociosas, descaradas e inconstantes (1615) de John Swetnam, y The Parliament of Women (1646), una sátira dirigida fundamentalmente contra las mujeres de clase media que las retrata atareadas tratando de crear leyes que les otorguen supremacía sobre sus maridos. Por otra parte, Federici señala que a estas obras de teatro y tratados se agregan los registros de la corte del periodo. Underdown concluye que "entre 1560 y 1640 estos registros revelan una intensa preocupación por las mujeres que son una amenaza visible para el sistema patriarcal. Mujeres discutiendo y peleando con sus vecinos, mujeres solteras que rechazan entrar en el servicio doméstico, esposas que dominan o golpean a sus maridos: todos aparecen con mayor frecuencia que en el periodo inmediatamente anterior o posterior. No pasa desapercibido que este es también el periodo en el que las acusaciones de brujería alcanzaron uno de sus picos" (Federici, 2010: 181).
} 
Atendiendo también a la efectividad de los discursos, Angela Davis ([1981] 2005) señala que "la literatura antiesclavista de la época perpetuaba las ideas racistas y las nociones sexistas que justificaban la exclusión de las mujeres de la arena política donde se libraría aquella batalla" (Davis, 2005: 53). Se construye así, según Davis, una ideología de la feminidad que comenzó a ensalzar los ideales de la esposa y de la madre en el momento en el que la manufactura se desplazó del hogar a la fábrica, lo que de manera simultánea convierte a las mujeres en apéndices de sus compañeros varones, "en sirvientas de sus maridos" (Ibíd.: 54). Pero, además, destacamos el aporte de Davis a la complejidad del análisis al señalar que esos modelos de feminidad permitieron, en relación con la esclavitud, la imposición de nuevas divisiones de clase, género y raza.

Nos resulta fundamental señalar que Colette Guillaumin articula la efectividad de discursos sobre la feminidad y la producción de subjetividades en "Práctica de poder e idea de Naturaleza" [1978 (2005)] donde además de reconocer que la naturaleza específica de la opresión de las mujeres en las sociedades capitalistas se vincula a que sus cuerpos son apropiados e intercambiados como bienes. Como da cuenta la autora en la siguiente cita:

... porque las mujeres, como todos los dominados, ejecutan desde luego tareas que no implican una relación directa y personalizada con otros seres humanos, pero, sobre todo, las mujeres siempre, y hoy en día en los países occidentales, únicamente ellas, están dedicadas a realizar por fuera del salariado, el cuidado corporal, material y eventualmente afectivo del conjunto de los actores sociales. Se trata a) de una prestación no monetaria, como lo sabemos y b) realizada en el marco de una relación personalizada durable.

(Guillaumin, 2005: 35)

Guillaumin examina y muestra que los discursos racistas producen "razas", junto con las construcciones simbólicas que definen sus características y que generó una serie de dicotomías conceptuales homologadas a sexo/raza. Para Guillaumin es el efecto material de la palabra ("la teoría no es sólo un acto contestatario") el que define la dimensión material de las relaciones de apropiación ya que la idea de naturaleza es la que luego sirve para enmascarar las opresiones. Sin embargo, señala Guillaumin, las relaciones entre sexismo y racismo en los procesos de subordinación de las mujeres (aun blancas) estaban naturalizados al punto de volverse invisibles. 
De manera que tanto como la raza, la pertenencia sexo/genérica fue un factor de discriminación, que requirió formas específicas de violencia para lograr la domesticación y la aniquilación de la alteridad. Lo cual manifiesta que el capitalismo debe justificar y mistificar las contradicciones incrustadas en sus relaciones sociales apelando a una (supuesta) naturaleza de aquellos a quienes explota: mujeres, súbditos coloniales, descendientes de esclavos africanos, inmigrantes "desplazados por la globalización" (Federici, 2010: 32). De allí que, uno de los discursos predilectos de las políticas oficiales de las colonias españolas -en las que la "raza" era el factor a partir del cual se ordenaba jerárquicamente la estructura social- era "Divide y reinarás" (2010: 196) bajo el cual se intentó romper todo tipo de alianzas y lazos entre mujeres, que existían más allá de la pertenencia étnico- racial. Tal como da cuenta la siguiente cita:

Las mujeres indias daban colibríes a las curanderas españolas para que los usaran para la atracción sexual, las mulatas enseñaron a las mestizas a domesticar a sus maridos, una hechicera loba contó sobre el Demonio a una coyota. Este sistema "popular" de creencias era paralelo al sistema de creencias de la Iglesia y se propagó tan rápidamente como el cristianismo por el Nuevo Mundo, de tal manera que después de un tiempo se hizo imposible distinguir qué era "indio" y qué era "español” o "africano.

(Federici, 2010: 97)

La partición de lazos sociales puede ser pensada como epistemicidio sexo genérico (Santos, 2010) en tanto destruyó un mundo de prácticas y saberes ancestrales que constituía el empoderamiento de las mujeres. En este sentido: "pasar de ser siervos del señor, a ser siervos del capital implicó una enorme destrucción: destrucción de recursos, de lazos, de saberes y de formas de resistencia" (Cielo y Vega, 2015: 135). Lo cual significó también la destrucción de la vida comunal -dictada por el interés económico específico de asegurar las condiciones para una economía capitalista- ya que "las formas previas de reproducción humana y natural fueron eliminadas" (Ibíd.: 136). Otras, basadas en "la privatización de las mujeres, de sus cuerpos y de su trabajo, fueron habilitadas en su lugar" (Ídem.).

En esta dirección Ciriza señala que, "la razón moderna, espejo de la naturaleza, será ella misma la modalidad única, universal y absoluta de la razón humana. Los sujetos que de ella no participen serán no- racionales, o bien no plenamente humanos" (Ciriza, 1994: 45) y por ello, pasibles de ser apropiados. Asimismo, puesto que la razón normativa de la burguesía será también la razón abstracta; regulará el orden de los 
fenómenos separables y calculables, excluyendo "lo que resiste el empeño analítico de la abstracción, como residuo irracional, aun cuando ese residuo devendrá colonizable" (Ídem). En esta línea, se torna plausible dilucidar que la explotación de las mujeres -y también de los sujetos colonizados, esclavizados y apropiados- es lo que ha permitido al capitalismo acrecentar sus ganancias y acumular trabajo "esclavo"; bajo una lógica de expropiación donde los discursos naturalistas legitimaron una serie de prácticas de apropiación y violencia ${ }^{157}$.

Efectivamente, el recurso al naturalismo, también es constitutivo de la ideología racista bajo la que se demoniza a los sujetos colonizados. Tal como revelan líneas teóricas críticas del colonialismo, es la supuesta naturaleza bestial y animal de los colonizados la que sirve para justificar el trabajo forzado que estos debían realizar, y la violencia extrema que se desató sobre sus cuerpos.

Para Quijano (2000) la modernidad y la colonialidad permiten ver el encastre entre la racialización total de la división del trabajo y la producción de conocimiento, que inferioriza y suprime al "otro", dando lugar a la colonialidad del poder, un poder capitalista, eurocentrado y global que surge a comienzos del siglo XVII que se imbrica con la idea de "raza". Pero lo que no puede ver Quijano, efecto de una ceguera de género según María Lugones (2012), es que las mujeres colonizadas son las más perjudicadas en el marco del sistema moderno- colonial de género. El argumento de Lugones tiene como punto de partida la afirmación de que la dicotomía fundamental de la colonialidad moderna "es la distinción entre lo humano y lo no-humano" (Ibíd.: 130) a partir de la cual los negros e indios- los no humanos- eran considerados como seres sin género: "en tanto bestias se los trató como totalmente accesibles sexualmente por el hombre y sexualmente peligrosos para la mujer" (Ídem).

En otras palabras: dado que, en el sistema colonial moderno, el género sólo aplica para quienes pertenecen al canon de "lo humano" (los blancos); los colonizados tendrán el estatuto de machos "no-humanos". Mientras que las colonizadas se constituyen en alteridad radical son "lo no humano de lo no macho". Lo cual habilitó que sufrieran todo tipo de aberraciones mediante la violencia extrema. Dado que:

La misión civilizadora colonial era la máscara eufemística del acceso brutal a los cuerpos de las personas a través de una explotación inimaginable de violaciones sexuales, del control de la reproducción y el terror sistemático (alimentando perros con personas vivas o

${ }^{157}$ Sobre la imbricación entre “apropiación” y “violencia” ver Souza Santos, 2010: 17. 
haciendo bolsas y sombreros de las vaginas de mujeres indígenas brutalmente asesinadas, por ejemplo).

La tesis de Lugones insiste en la idea de que el cuerpo de las mujeres necesariamente ha sido un campo de batalla para los pueblos y para los masculinos que combaten entre sí, puesto que "somos territorios aptos para ser expropiados", o más bien: "refeudalizados" (Segato, 2016: 21) ${ }^{158}$. Para Segato las sociedades patriarcales de la modernidad colonial están estructuradas a partir del despojo del poder femenino por parte de los sujetos masculinos y del Estado de clases, lo cual requiere de la violencia como elemento central para estructurar ese dominio de lo masculino sobre lo femenino y de la desigualdad entre estos términos. Bajo esta línea de análisis, el disciplinamiento que intenta "encausar" a las mujeres en los roles socialmente establecidos es el mismo que opera detrás de todas las formas de violencia de género hasta la actualidad.

Siguiendo esta tesis en nuestro contexto local y regional ${ }^{159}$ cabe preguntar: ¿qué relación guarda la avanzada neoliberal y neoconservadora con la creciente ola de violencia contra las mujeres? Es bajo el despliegue un discurso moral -bajo el "nombre de Dios" o "por el bien de la familia"- que se pretende limitar el control y autonomía de las mujeres sobre sus cuerpos; lo que involucra también una retórica antigénero, para mantener el orden instituido. Bajo nuestra perspectiva, en este rechazo al "género" se manifiesta sintomáticamente la politicidad de este y su potencialidad para desestabilizar las estructuras que reproducen las condiciones de opresión, puesto que el género "es la piedra angular y el eje de gravedad de todos los poderes" (Segato, 2016: 15-16).

En el próximo capítulo proponemos analizar el fenómeno ideológico discursivo de rechazo a lo que sectores neoconservadores y neoliberales representan como “ideología de género", su genealogía y las implicancias que tiene su uso en un nuevo marco. Lo que nos conduce nuevamente al silencio teórico de Althusser -y de discursos androcéntricos- respecto a las subjetividades feminizadas.

\footnotetext{
${ }^{158}$ No obstante, hay que decir que, entre las posiciones de Lugones y de Segato existen importantes diferencias a pesar de que ambas realicen una fuerte crítica al patriarcado colonial moderno. Mientras que Lugones sostiene que la idea de raza como la de género se producen de manera simultánea en el proceso de conquista y colonización; para Segato, el género existía antes de la conquista, y también existía un patriarcado de baja intensidad en las comunidades ancestrales, las que se ven transformadas a partir del orden colonial/ moderno (ver Lugones, 2012; Segato, 2016; Espinosa, 2014).

159 Partimos de la idea de que asistimos a un cierre de ciclo de gobiernos progresistas que se oponen a políticas neoliberales, para dar comienzo principalmente desde 2010 en Chile, 2012 en Paraguay y 2015 en Brasil y Argentina, a gobiernos de derecha, llamadas así en un sentido laxo.
} 


\section{Capítulo IX. La ideología de género}

En las sociedades primitivas, la misoginia queda expresada en tabúes y manas que dan lugar a una serie de mitos explicativos. En las civilizaciones históricas, tales mitos se transforman en principios éticos y manifestaciones literarias (reemplazados, en la época actual, por racionalizaciones cientificas de la politica

sexual).

(Kate Millet, Política sexual)

En este capítulo proponemos mostrar que los ataques a lo que ciertos sectores representan como "ideología de género" coloca en el centro de la escena política al concepto de "género". Nuestra hipótesis es que en esta formación ideológico- discursiva asistimos tanto a una apropiación de formulaciones realizadas desde perspectivas teóricas feministas, como a la restitución de un tratamiento de tipo idealista de la noción de "ideología" ya que se la comprende como mistificación de la realidad. Para ello, trazaremos vínculos teóricos entre el concepto de género y el de ideología.

Por otra parte, las tensiones en el plano teórico, desembocan en un diagnóstico de despolitización y de simplificación del género que, sin embargo, desde una lectura sintomal, revela el núcleo político del concepto; junto con la necesidad de repolitizarlo y de recomplejizarlo mediante el trazado de genealogías feministas críticas ${ }^{160}$ e interseccionales.

${ }^{160}$ La noción de genealogía -en su reconceptualización foucaultiana- es una herramienta de análisis fundamental en tanto posibilita remover y desedimentar procesos que se perciben inmóviles (Foucault, 1982). 


\section{La ideología de género desde una perspectiva feminista}

- Cuando yo uso una palabra" en un tono bastante desdeñoso, "significa

lo que yo decido que signifique- ni más ni menos

- la cuestión es", dijo Alicia, "si usted puede hacer que las palabras

signifiquen cosas tan diferentes

-la cuestión es dijo Humpty Dumpty, "quien es el amo - eso es todo.

(Alicia en el país de las maravillas de Levvis Carrol.

Citado por Teresa de Lauretis en Alicia ya no)

Aunque la articulación entre ideología y género esté ausente del discurso filosófico de Althusser $-\mathrm{y}$ del canon androcéntrico ${ }^{161}$ - se trata de una cuestión abordada explícitamente por Teresa de Lauretis en la Tecnología del género [1989 (1996)] quien busca explicar el proceso de generización de las subjetividades y para ello, apela a una situación cotidiana -como el de completar un formulario y marcar el casillero " $F$ "- para dar cuenta del ingreso en el sistema sexo/ género y en las relaciones sociales de género por las cuales "devenimos en-gendradas [engendered] como mujeres" (Ibíd.: 18); y no sólo porque los demás nos perciban mujeres, sino porque nos hemos representado a nosotras mismas como mujeres. Este acto de internalización del género es homologable para Lauretis, a la escena de la interpelación ideológica entendida como un "proceso por el cual una representación social es aceptada y absorbida por un individuo como su propia representación" 162 .

Sin embargo, Lauretis advierte críticamente que, en el marco de la propuesta althusseriana existe un silencio teórico respecto al género - ya que la interpelación ideológica es presentada como un mecanismo que se dirige a todos, sin importar "los quien"- a pesar de que el género es constitutivo de las relaciones que estructuran la sociedad. Por ello es que, para Lauretis, el discurso de Althusser es ciego de su propia complicidad con la ideología de género, e incluso, para la filósofa italiana dado el nivel

\footnotetext{
161 Alejandra Ciriza (2015) remite a un artículo de Jorge Gracia, relativo a los cánones filosóficos y sus funciones, en el que se enfatiza que "los cánones introducen parámetros de inclusión que dejan fuera de consideración mucho de lo que forma parte de la historia... un canon filosófico consiste de la lista de autores y textos que son repetidamente estudiados tanto filosófica como histórica-mente" (Gracia, Jorge, 2010: 3). Ahora bien, considerando el canon androcéntrico y euronorcéntrico, hay lecturas que destacan que la noción de ideología de Derrida en la década de 1970 tiene un énfasis puesto en la diferencia sexual (Cfr. Mercier, 2019), con lo cual podría ser considerado como una excepción.

${ }^{162}$ En los términos de Pêcheux, la interpelación es "el proceso natural y sociohistórico por el cual se constituye y reproduce el efecto sujeto como 'interior sin exterior' - por medio de la determinación de lo real (exterior) y del interdiscurso como real ('exterior') (Pêcheux, 1975: 148).
} 
de institucionalización que la teoría althusseriana tiene sobre los significados sociales, hace que esta pueda ser pensada como una tecnología de género.

Ahora bien, en esta ausencia de la cuestión de género en el planteo de Althusser -una ausencia heredada del marxismo tradicional ${ }^{163}$ y de la filosofía canónica donde el género es una cuestión marginal- Lauretis ve justamente, el síntoma de una descripción del funcionamiento del género. Para ello, propone sustituir en la tesis althusseriana de que "toda ideología tiene la función de constituir individuos concretos en sujetos" (IAEI: 53) el término ideología por el de género. Bajo la convicción de que esa sustitución permite mantener la eficacia del discurso ideológico, puesto que: “...el género tiene la función (que lo define) de constituir individuos concretos como varones y mujeres. Para la autora, en ese cambio es precisamente donde se puede ver la relación de género con la ideología y vérselo también como un efecto de la ideología del género" (Lauretis, 1996: 12.).

En esa dirección avanza Lauretis y señala que, si Althusser no traza el nexo entre ideología y género, esta articulación ha sido realizada por autoras feministas como Michèle Barrett quien afirma que la ideología no es sólo un lugar primario de la construcción del género, sino que, la ideología del género: "ha jugado un rol importante en la construcción histórica de la división capitalista del trabajo y en la reproducción de la fuerza de trabajo" (Ídem). Con lo cual, enfatiza el nexo fundamental entre ideología y relaciones de producción. Sin embargo, para Lauretis, el sistema conceptual de Barrett, no permite una comprensión de la ideología de género en términos específicamente feministas, porque propone entenderla más bien como una parte de la totalidad social, que como un discurso o prácticas autónomos. Quizás, por su compromiso con la cuestión de la autonomía relativa de "la ideología (en general, y presumiblemente, de la ideología de género en particular) respecto de los medios y las fuerzas de producción y/o de las relaciones sociales de producción" (Ibíd.: 14).

Una alternativa se encuentra, según Lauretis, en un ensayo de Joan Kelly de 1979 donde la autora rechaza toda pretensión de sostener que hay dos esferas de la realidad: la privada (la doméstica, la familia, etc.) y la pública/ productiva. Y propone pensar en varias relaciones sociales interconectadas: de clase, de raza, y de sexo/género, en las que hombres y mujeres están posicionados de manera diferencial. Para Kelly en

\footnotetext{
163 que "se limita a la mujer a la esfera privada de la reproducción, de la procreación y de la familia" (Lauretis, 1996.: 12).
} 
cualquiera de las formas históricas que toma la sociedad patriarcal (feudal, capitalista, socialista) "un sistema de sexo/género y un sistema de relaciones productivas operan simultáneamente para reproducir las estructuras masculino- dominantes y socioeconómicas de ese orden social particular" (citado por Lauretis, 1996: 15). En esta doble perspectiva, según Lauretis, es posible comprender cómo opera la ideología de género: asegurar el lugar de la mujer dentro del sistema sexo/ género.

Es precisamente en este punto, donde Lauretis destaca la importancia de la función subjetiva de la ideología propuesta por Althusser ${ }^{164}$. Pero, a diferencia de este para quien el sujeto se encontraría completamente inmerso en la ideología -aunque crea que está fuera- para Lauretis eso no ocurre con el sujeto del feminismo que "está al mismo tiempo dentro y fuera de la ideología de género, y que es consciente de estarlo" (Ibíd.: 16). Se trata según la autora, de una complicidad - no adhesión plena, sino tensionada- del feminismo con la ideología de género, entendida como heterosexismo. Cabe señalar que para Lauretis, el uso corriente del término heterosexual para referir a las prácticas sexuales entre sexos opuestos, "tiende a oscurecer la no naturaleza de la heterosexualidad misma" (Ibíd.: 10) porque obstaculiza comprender que se trata de una naturaleza socialmente construida, que depende más bien de la construcción semiótica del género, que de la existencia física biológica de los dos sexos. Frente a lo cual, Lauretis propone comprender la heterosexualidad como un aparato ideológico de estado regulada por la ideología de género ( $\sin$ embargo, se trataba de una tesis que no se hallaba ampliamente aceptado por las feministas).

Lauretis argumenta que el género no es sexo, estado de naturaleza, sino la representación de cada individuo en el marco de una relación social particular que preexiste al individuo y está fundada sobre la oposición conceptual y rígida (estructural) de dos sexos biológicos, lo que "científicas sociales feministas han llamado sistema sexo/ género" (Ibíd.: 11). Apuntando contra la propuesta de Rubín del sistema sexo/ género como contraposición entre "naturaleza/ cultura". Desde un nuevo marco de análisis, Lauretis afirma que el sistema sexo/ género constituye en cada cultura un sistema de representación que otorga significados (identidad, prestigio, posición en el sistema de parentesco, estatus social) a los individuos, correlacionando el sexo con contenidos culturales de acuerdo con valores y jerarquías. En consecuencia "la

${ }^{164}$ Lauretis señala que "la ideología necesita un sujeto, un individuo concreto o una persona para obrar sobre ella" (1996: 15). Es necesario atender en este sentido, que se trata de niveles teóricos distintos que la filósofa feminista equipara. 
construcción del género es tanto el producto como el proceso de su representación" (Ídem). Pero, señala Lauretis, no sólo en el sentido de que cada signo, cada palabra, refiere a su referente, sino que el género representa "a una relación social (...) representa a un individuo en una clase" (Ibíd.: 10).

Entonces bien, Lauretis reconoce como un acierto de Althusser que este señale que la ideología puede operar gracias a su apelación a la subjetividad ya que la categoría de sujeto es constitutiva de toda ideología. Pero no acuerda con su postulación de un sujeto sin género; un sujeto según Lauretis, vinculado con el psicoanálisis de Lacan que, al concebir el falo como el significante único y universal del poder, concibe a la mujer como "mero portador de carencia colocándola fuera de lo simbólico, fuera de lo social y de lo cultural" (Colaizzi, 1990). De allí que, en el psicoanálisis, "la mujer como sujeto de deseo o de significación, sea irrepresentable" (Lauretis, 1996: 27).

Que Lauretis -crítica de Althusser- afirme que la "ideología apela a la subjetividad, implica desde nuestra perspectiva, un equívoco puesto que, de acuerdo con lo examinado en la segunda parte de este trabajo, ideología y "sujeto" se encuentran en una relación de inmanencia. No existe una subjetividad previa a la que pueda apelar la ideología, porque supondría comprender al sujeto como un dato fundamental, disponible ${ }^{165}$, como en los abordajes de tipo idealista. Desde una perspectiva materialista recordemos, el efecto- sujeto se constituye en el proceso mismo de la interpelación.

Dicho esto entonces, para Lauretis, la situación de las mujeres puede concebirse como "paradójica" ya que están ausentes como sujetos teóricos de los discursos androcéntricos - que si las incluyen es sólo como objetos de sus representaciones ${ }^{166}$-; y están prisioneras en tanto sujetos históricos, de la cultura de los hombres. Es decir que, las mujeres están a la vez dentro y fuera del género, a la vez dentro y fuera de la

\footnotetext{
${ }^{165}$ Este mismo desliz lo encontramos en la descripción que Lauretis hace de la experiencia como "proceso de construcción social de la subjetividad. Como un complejo de significado, hábitos, disposiciones, asociaciones y percepciones resultantes de la interacción semiótica del 'yo' y 'del mundo externo' (Lauretis, 1992: 26). Consideramos que allí la filósofa italiana está postulando la anterioridad de un sujeto.

${ }^{166}$ En el caso de los discursos científicos, hay una ausencia del punto de vista de las mujeres en tanto sujetos de conocimiento (Haraway, 1991; Harding, 1996).
} 
representación Mujer. Este sujeto ("las mujeres") ${ }^{167}$-que Lauretis repone para el discurso feminista- refiere a "seres históricos reales que, a pesar de no poder ser definidos al margen de esas formaciones discursivas, poseen, no obstante, una existencia material evidente" (Lauretis, 1992: 15-16).

Ahora bien, frente al canon y el poder masculino hegemónico, que mantiene a "la conciencia feminista y a la sexualidad femenina dentro del círculo vicioso de la paradoja de la mujer" (Lauretis, 1993: 8) ${ }^{168}$; Lauretis propone una posición discursiva excéntrica que revaloriza "los discursos de las minorías y la afirmación de los saberes subyugados como parte de la crítica al discurso colonial, y de la crítica feminista a la cultura occidental y al feminismo (blanco) occidental" (Ibíd.: 9).

En esta dirección, aunque la estructura del sistema sexo/ género parece no poder eludirse, (como la estructura de la ideología althusseriana fuera de la que parecería no existir nada) Lauretis propone una alternativa que da lugar a la agencia a partir de la posición excéntrica. Como da cuenta la siguiente cita:

...no sólo en el sentido de desviarse de la senda convencional, normativa, sino también ek- 'céntrico en el sentido de que no se centraba en la institución que sostiene y produce la mente hétero, es decir, la institución de la heterosexualidad (...). Lo que caracteriza al sujeto excéntrico es un doble desplazamiento: primero, el desplazamiento psíquico de la energía erótica hacia una figura que excede las categorías de sexo y género, la figura que Wittig llamó "la lesbiana". Segundo: el auto-desplazamiento o la desidentificación del sujeto de los supuestos culturales y las prácticas sociales inherentes a las categorías de género y sexo.

(Lauretis, 2015: 4)

En otros términos, de lo que se trata es de producir prácticas y discursos feministas desde los márgenes, desde los intersticios de las instituciones para dar lugar a las subjetividades dislocadas, disidentes: "fuera del monopolio del poder/saber (hétero) sexual masculino" (ídem) ${ }^{169}$. Esta posibilidad de resistencia y de desidentificación con

\footnotetext{
${ }^{167}$ Aquí los órdenes Mujer/ mujeres se comprenden como formando parte de un proceso social y material constitutivo (de manera análoga a la relación Sujeto/ sujetos en la estructura de la ideología propuesta por Althusser); con una materialidad compleja entendida como heteronormatividad.

${ }^{168}$ La posibilidad de una conciencia de género es derivada, como señala Cháneton de "la antropología marxista, desde la cual, en tanto posicionamiento, no puede haber retorno a la 'inocencia de la biología" (Cháneton, 2007: 81).

${ }^{169}$ Para María Luisa Femenías (2012) de lo que se trata entonces es de producir "un discurso alternativo que se constituye, por un lado, en práctica cognoscitiva, y 'saber inusual o anómalo'; por otro, en conciencia de la excentricidad y del cambio” (Femenías, 2012: 88-89).
} 
el discurso masculino hegemónico está dada, según Lauretis, porque la construcción del género es:

...también afectada por su deconstrucción; es decir por cualquier discurso,

feminista u otro, que pudiera dejarla de lado como una tergiversación ideológica. Porque el género, como lo real, es no sólo el efecto de la representación sino también su exceso, lo que permanece fuera del discurso como trauma potencial que, si no se lo contiene, puede romper o desestabilizar cualquier representación.

(Lauretis, 2015: 9)

Lo cual implica un proceso de nueva comprensión de la historia y de la cultura ya que "es una posición que se logra sólo por medio de las prácticas del desplazamiento político y personal a través de los límites de las identidades sociosexuales y de las comunidades entre los cuerpos y los discursos" (Lauretis: 1993: 106). La propuesta teórico- político de Lauretis busca entre otras cosas, subvertir la ideología de género en el marco de un proyecto más amplio de abonar a prácticas y discursos emancipadores. Sin embargo, como examinaremos, la expresión "ideología de género" es utilizada por ciertos sectores reaccionarios a la ampliación de derechos de grupos históricamente marginados, con fines adversos. Lo cual requiere un análisis comparativo entre la "ideología" y el "género" que implica subsidiariamente, un rodeo en torno a las vicisitudes de ambos conceptos.

\section{Vicisitudes del concepto de ideología}

Mutato nomine de te fabula narratur" /" Bajo otro nombre a ti se refiere la historia.

(Horario, Sátiras)

El término ideología fue utilizado por primera vez por Destutt de Tracy (17541836) a fines del siglo XVIII, para bautizar a una nueva ciencia que debía dedicarse al estudio científico de las ideas (Barth, 1951; Lenk, 2007).

La ciencia de las ideas a la que Destutt denomina "ideología" era considerada parte de la zoología, y concebida como una físiología según postulados empiristas semejantes a los de Locke: las ideas tenían su fuente en la sensación, y su estudio debía permitir comprender la génesis de las ideas y al mismo tiempo, debía permitir examinar 
el pensamiento humano del mismo modo como se observa y se describe un objeto de la naturaleza. La "ideología" basada en observaciones tenía como objeto el establecimiento del origen de las ideas, y para ello debían dejarse a un lado los prejuicios religiosos y metafísicos, ya que el progreso científico sería posible si las ideas falsas eran rechazadas. En este sentido, la teoría de los ídolos de Bacon propuesta en $L a$ Instauratio magna tuvo una influencia sobre la ciencia de las ideas ya que allí la teoría de los ídolos funciona como un modo de impedir la génesis de las ideas falsas, limitando y definiéndolas con rigor. Con lo cual se pone de manifiesto la pretensión de que la ciencia de las ideas alcance el mismo grado de certeza que las ciencias fisicomatemáticas.

Para Destutt una de las consecuencias prácticas de la ideología consistía en poder ofrecer por medio de esta ciencia, una sólida base a las ciencias morales, políticas y pedagógicas. De manera que, en su primera formulación el término de ideología tiene una connotación positiva, ya que hace referencia a la ciencia rigurosa de las ideas que, superando los prejuicios religiosos y metafísicos podía servir de base para la educación y formación del pueblo.

Sin embargo, el concepto de ideología comienza a tener un sentido peyorativo cuando Napoleón Bonaparte utiliza este término para insultar a los miembros del Instituto de Francia, sus antiguos aliados, que le quitan apoyo tras ciertos excesos despóticos por parte de Napoleón. Es en ese momento que este los apodó de "ideólogos" con el significado negativo de que eran intelectuales doctrinarios, enemigos de la Iglesia y el Estado, y los acusó de ser "los responsables de los catastróficos errores de la política imperialista y de todas las desgracias que había conocido Francia" (Barth, 1951: 23). Como consecuencia, Napoleón prohíbe la enseñanza de la Ciencia Moral y Política por considerarla "ideología".

Durante la mayor parte del siglo XIX la ideología tuvo esta connotación negativa. Pero, además, por un largo periodo este término tuvo escasa trascendencia, ya sea como ciencia de las ideas o como una teoría doctrinaria, la ideología como ciencia no había logrado establecerse, ni en Francia ni en otros países.

El desarrollo más frondoso de la ideología se inscribe a partir de la formulación realizada en La ideología alemana de Marx y Engels, en la que el término es caracterizado por los autores principalmente como "falsa conciencia", distorsión de las condiciones reales de existencia. De acuerdo con la lectura de Althusser, a partir de esta obra de 1845 , comienza a darse un proceso de ruptura con la comprensión de la como 
mera ilusión y como error, para pasar a ser comprendida desde su existencia material en prácticas y rituales prescriptos por instituciones, los "aparatos ideológicos del Estado". Esta lectura althusseriana de la ideología toma como punto de partida la tesis marxista según la cual "no es la conciencia la que determina la vida, sino la vida la que determina la conciencia" (LIA: 26) para afirmar que la ideología tiene una existencia material en la superestructura fundada en la lucha de clases, es decir, que existe una determinación material de las ideas. En contraposición por ejemplo, a la interpretación de Bauer y Stirner ${ }^{170}$ que sostendrían que el motor de la historia es el desarrollo de las ideas; y, en rechazo al idealismo de sus antecesores que escinde la esfera del pensamiento de la esfera material y corpórea. (cfr. Parte I).

Antonio Gramsci, en los Cuadernos de la Cárcel critica el "juicio de valor negativo" que se le ha atribuido a la ideología en la filosofía marxista al ser concebida como "pura apariencia", determinada sólo por la base económica. Frente a lo cual propone un sentido positivo bajo el que "las ideologías históricamente orgánicas (...) crean el terreno sobre el que los hombres se mueven, adquieren conciencia de clase, lucha, etc." (Barret, 2008: 266).

En un sentido positivo opera también la "ideología proletaria" término que adoptó a fines de la década de 1920 el leninismo- estalinismo con el fin de designar no la "distorsión" de la conciencia proletaria, sino la "propia fuerza subjetiva" impulsora de la actividad revolucionaria de proletariado. A partir de ahora la ideología también incluye a la ideología proletaria o revolucionaria, que implica, por el contrario, una concepción "recta" de la realidad -en tanto concibe a la sociedad como dividida en clases sociales de las cuales una explota a la otra-; y, por tanto, incluye la conciencia de pretender transformar esa realidad. Esa reformulación del concepto de ideología estaría vinculado a la reinterpretación del propio marxismo como una "ciencia objetiva" imparcial, como una ciencia que no contiene en sí misma la posición subjetiva

\footnotetext{
170 "Toda la crítica filosófica alemana desde Strauss hasta Stirner se limita a la crítica de las ideas religiosas. Se partía de la religión real y de la verdadera teología. Qué fuera la conciencia religiosa, la idea religiosa, se determinaba de distinto modo en el curso ulterior. El progreso consistía en englobar las ideas metafísicas, políticas, jurídicas, morales y de otro tipo supuestamente imperantes, bajo la esfera de las ideas religiosas o teológicas (...) Partíase como premisa del imperio de la religión. Poco a poco, toda relación dominante se explicaba como una relación religiosa y se convertía en culto, en culto del derecho, culto del Estado, etc. Por todas partes se veían dogmas, nada más que dogmas, y la fe en ellos" (Marx y Engels, 2005: 17).
} 
$\operatorname{proletaria}^{171}$.

Cabe señalar que dentro y fuera del marxismo existen otros significados del concepto de ideología. Dentro de la tradición marxista, se encuentra, por ejemplo, el anteriormente mencionado sentido de la ideología como un sistema de creencias propios de una clase o grupo particular. Este término neutral no implica "verdad" ni "error", pero con referencia positiva a una situación y a un interés social y a un sistema constituido de valores tal como es presentado por Lenin cuando habla de una "ideología socialista". Para Lenin, la "ideología" en su acepción neutra, es "introducida" en la fundación de "todo el conocimiento humano y científico" aplicado desde un punto de vista de clase.

También el término ideología es utilizado para describir los procesos de toda significación, incluyendo la significación de los valores. En este sentido, por ejemplo, Valentín Volóshinov (2009) utiliza el término “ideológico” para describir el proceso de significados a través de signos; y el de "ideología" lo usa para designar la dimensión de la experiencia social en que los significados y los valores son producidos. Este énfasis puesto sobre la significación como proceso social fundamental, de algún modo intenta resolver las dificultades de Marx y Engels y de gran parte de la tradición marxista, de “comprender que los procesos fundamentales de significación social son intrínsecos a la conciencia práctica y a las concepciones, pensamientos e ideas” (Williams, 2009: 101).

Por su parte, Göran Therborn (1980) sostendrá que la ideología es "aquel aspecto de la condición humana bajo el cual los seres humanos viven sus vidas como actores conscientes en un mundo que tiene sentido para ellos en grados diversos" (Therborn, 1980: 2). La ideología es comprendida así, como el medio a través del cual operan esta conciencia y este otorgamiento de sentido.

Como anticipamos, el propósito de este rodeo en torno a la acuñación y las vicisitudes del concepto de ideología, es el de mostrar que en la formación ideológicodiscursiva contra la 'ideología de género', se produce una restitución del tratamiento idealista de la ideología, según el cual, esta es una mera "falsa conciencia".

\section{El rechazo a la "ideología de género"}

\footnotetext{
171 Para Zizek "el marxismo primero, desde la distancia neutral del metalenguaje, se cerciora de la tendencia objetiva de la historia hacia el comunismo; luego, elabora la 'ideología proletaria' para inducir a la clase obrera a cumplir su misión histórica" (SOI: 16).
} 
A nivel local y regional asistimos desde hace más de una década a un fenómeno ideológico discursivo por parte de un activismo reactivo -que aglutina tanto al conservadurismo religioso, como a laicos neoliberales ${ }^{172}$ - que insisten en demonizar lo que representan como "ideología de género"; constructo que implica por un lado, tanto un tratamiento idealista de la ideología, como un tratamiento biologicista y naturalista del género.

En Argentina existe un ferviente rechazo por parte de grupos vinculados a la iglesia católica y evangélica -esta última con un gran crecimiento político, en términos de politización reactiva ${ }^{173}$ - contra el proyecto actual de reforma de la ley 26.150 de Educación Sexual Integral (ESI) sancionada en 2006, para que esta sea implementada en las escuelas de manera, laica, obligatoria y con perspectiva de género ${ }^{174}$ (de manera análoga, según nuestra perspectiva, a cómo Napoleón prohíbe la enseñanza de la Ciencia Moral y Política por considerarla “ideología”).

Las modificaciones propuestas a la actual ley ESI apuntan a incluir explícitamente el respeto por la diversidad sexual y de género, el carácter científico y laico de la ESI, y a establecer que esta sea aplicada de manera obligatoria en todo el territorio nacional, en instituciones de gestión estatal o privada, más allá del "ideario institucional y de las convicciones de sus miembros". Son estas modificaciones las que han suscitado un virulento rechazo por parte de sectores conservadores que argumentan que se trata de "ideología de género" que fomentaría el aborto ${ }^{175}$, la masturbación, la promiscuidad y las orientaciones sexuales "anómalas". Lo cual, tendría como efecto, la

\footnotetext{
${ }^{172}$ Lo que manifiesta la alianza del neoconservadurismo y del neoliberalismo en sostener el capitalismo patriarcal, lo que supone oponerse conjuntamente a la disolución de valores conservadores, donde ocupa un lugar destacado la familia tradicional; oponerse a la disolución del binomio Mujer- Madre; y a la perspectiva de género que amenaza con subvertir el orden instituido.

173 A propósito del fenómeno de "expansión del evangelismo" como movimiento ("¿de opción por los pobres?" de, "iteología de la prosperidad?") existen sugerentes investigaciones que vinculan el fenómeno de su crecimiento con el avance de gobiernos de derecha en países latinoamericanos. Para ampliar sobre este fenómeno en Brasil se recomienda: https://nuso.org/articulo/por-que-crece-el-evangelismo-en-brasily-que-consecuencias-politicas-tiene/;https://nuso.org/articulo/los-evangelicos-y-el-hermano-bolsonaro/.

Desde estos enfoques, tal avance expansivo tiene el estatuto de politización reactiva (describe el accionar de instituciones y grupos religiosos conservadores como parte de la sociedad civil, movilizándose contra la emancipación de género y sexual.

${ }^{174}$ Para ampliar ver Proyecto de Ley "Modificación a la ley 26.150 del Programa de educación Sexual Integral" presentado al Senado y la Cámara de diputados de la Nación Argentina. Disponible online: https://www4.hcdn.gob.ar/dependencias/dsecretaria/Periodo2018/PDF2018/TP2018/5242-D-2018.pdf.

${ }^{175}$ En el caso del aborto, desde el activismo reaccionario, se conecta su legalización con el financiamiento público ("con mis impuestos no"), la justicia de clase, la tutela patriarcal de las jóvenes (Vega, 2019: 78).
} 
destrucción de la familia -entendida de manera unívoca ${ }^{176}$ - y la destrucción de la naturaleza -de origen divino- que emanaría dicotómicamente a varones y mujeres.

En este marco, las sexo- disidencias, no sólo serían antinaturales, y "demoníacas" (en oposición al carácter sagrado) sino que además serían promocionadas por esta "ideología de género". Frente a lo cual, sectores vinculados a la Iglesia católica $\mathrm{y}$ evangélica ${ }^{177}$ aseguran que deben ser los padres y la familia los que elijan y supervisen (exclusivamente) los contenidos y el modo de educar sexualmente. De lo contrario, argumentan, habría un Estado imponiendo contenidos morales por encima de la posibilidad de las familias de educar de acuerdo a sus convicciones.

Se trata de una cuestión social muy compleja, ya que a pesar de que la ley ESI tuvo apoyo en el Congreso Nacional argentino a partir de los debates sobre la legalización de la Interrupción Voluntaria del Embarazo (IVE) -cuyo proyecto de ley ${ }^{178}$ obtuvo media sanción el 13 de junio de 2018 en la Cámara de Diputados de la Nación Argentina ${ }^{179}-y$, a pesar de que es una demanda de gran parte de la sociedad, sobre todo de jóvenes, se sigue negando el derecho "que todos los educandos tienen" a "la educación sexual integral que articula aspectos biológicos, psicológicos, sociales, afectivos y éticos" (fragmento del artículo 1 de la ley de ESI).

Si analizamos lo que efectivamente propone la ley a través de sus artículos y las resoluciones 43/2008 y la 340/ 2018 del Consejo Federal de Educación -encargadas de garantizar los lineamientos, los materiales curriculares y recursos didácticos, para planificar las capacitaciones y realizar un seguimiento de su implementación- podemos afirmar que lo que busca esta ley es: una mayor conciencia sobre la autonomía de los cuerpos, la prevención de abusos, el reconocimiento del deseo propio, el respeto hacia las disidencias y las identidades sexuales no binarias, la reflexión sobre los afectos, el rechazo de todas las formas de violencia, de discriminación y de exclusión. Entonces:

\footnotetext{
${ }^{176}$ Alejandra Ciriza nos recuerda en este sentido, que, entre las estrategias retóricas del conservadurismo religioso, se encuentra la sustitución de "grupo familiar" por familia (Ciriza, 2007: 16).

177 Durante mucho tiempo la Iglesia Católica en Argentina ejercía su influencia a través de los altos mandos del gobierno de manera más o menos directa. En las últimas décadas, sus estrategias se han diversificado y se han fortalecido las que ponen el foco en la sociedad civil. Se trata de una serie de ONG que han crecido y se han multiplicado en Latinoamérica, así como grupos laicos, entre los que se destaca el Opus Dei.

178 El nuevo proyecto de ley presentado el 28 de mayo de 2019, tiene una serie de modificaciones respecto al que obtuvo la media sanción en Diputados y que fue frenado en la Cámara de Senadores. Estas se encuentran disponibles en:http://www.abortolegal.com.ar/proyecto-de-ley-presentado-por-la-campana/ ${ }^{179}$ Con el impulso del Frente de Educación Sexual Integral y el Frente de Docentes por el Derechos a Decidir, el 4 de septiembre, el Día Mundial de la Salud Sexual, se alcanzó un dictamen de mayoría en reunión plenaria de comisiones de Educación y de Mujer, Niñez y Familia de la Cámara de Diputados.
} 
¿por qué obstaculizar su efectiva implementación, siendo que en las jurisdicciones donde se implementó se ha probado positivamente su efectividad, expresada entre otras cuestiones, en el reconocimiento de abusos infantiles? Lo que conduce por otra parte, a otra cuestión problemática: la palabra de lxs niñxs a menudo es silenciada, puesta en duda y anulada.

Ha sido gracias a contenidos impartidos por la ESI como el conocimiento y el cuidado del propio cuerpo, el reconocimiento de los deseos propios, y la distinción entre afecto y abuso; que muchos niñxs y adolescentes detectaron situaciones en las que se vieron violentados, en la mayoría de los casos en el ámbito intrafamiliar. ¿Por qué entonces dejar que este tipo de educación sea justamente impartido por los propios miembros de la familia?

La reacción de repudio de los grupos del neoconservadurismo religioso y liberal -entre los que se destacan los grupos "pro vida" ante la posibilidad de efectivizar las modificaciones a la ley ESI- se manifestó en marchas y campañas bajo las consignas: "Con mis hijos no te metas", "Los hijos son de los padres, no del Estado"; "No a la ideología de género en la escuela". Se trata de un activismo religioso conservador que defiende un orden sexual tradicional que lleva adelante distintas estrategias para evitar la "cultura de la muerte" frente a lo que llaman una "cultura de la vida", de la cual se declaran sus guardianes. Por ello es que desde los movimientos feministas se planificó una estrategia consistente en desplazar el eje de la "vida" hacia el de la "libertad" (que se ilustra por ejemplo en el lema "aborto legal para no morir" por el siguiente: "aborto legal en cualquier lugar").

Las campañas de estos grupos contra la 'ideología de género' ha sido desarrollada en otros países como México, Brasil ${ }^{180}$, Colombia, Chile, Perú y Ecuador, con distintas características. Lo que revela que el efecto multiplicador internacional y regional es muy potente. Frente a lo que cabe preguntarse: ¿cómo leer la coincidencia entre la Campaña reaccionaria Con mi hijo no te metas, con un nuevo y potente ciclo de feminismo callejero, iniciado en 2016, cuya fuerza se irradió desde Argentina y multiplicó expresiones en el resto del continente?

\footnotetext{
${ }^{180}$ Rita Segato señala que la expresión "ideología de género" como categoría de acusación, ha servido para estructurar por ejemplo en Brasil un proyecto de ley federal llamado "Ley de la Escuela Sin Partido" que establece la prohibición en las escuelas estatales de la "aplicación de los postulados de la ideología de género" (artículo 1); y de "cualquier práctica que pueda comprometer, precipitar u orientar la maduración y el desarrollo en armonía con la respectiva identidad biológica de sexo" (Segato, 2016: 17).
} 


\section{El género bajo ataque}

La burguesía desgarró los velos emotivos y sentimentales que envolvían la familia y puso al desnudo la realidad económica de las relaciones familiares (...) ¡Abolición de la familia! Al hablar de estas intenciones satánicas de los comunistas, hasta los más radicales gritan: jescándalo! Pero veamos: ¿en qué se funda la familia actual, la familia burguesa? En el capital, en el lucro privado. Sólo la burguesía tiene una familia, en el pleno sentido de la palabra; y esta familia encuentra su complemento en la carencia forzosa de relaciones familiares de los proletarios y en la

pública prostitución (...)

(Marx, El Manifiesto comunista)

Las movilizaciones masivas de la campaña Con mi hijo no te metas tuvo como epicentro la ofensiva contra la denominada "ideología de género". Los movimientos conservadores ${ }^{181}$ mediante una retórica antigénero se confrontan con el feminismo en movimiento y su potencialidad de instituirse en políticas del Estado y avanzar en materia de derechos. Lo cual se ilustra en la articulación con el Estado, amparándose en declaraciones de organismos internacionales como la ONU.

Más allá de este "amparo estatal", desde la década del 2010 los movimientos feministas, y de mujeres han cobrado centralidad y nuevos bríos, al decir de Vega (2019) debido al impacto que las crisis sociales, económicas y políticas tienen sobre las mujeres "encargadas de sostener la vida", como hemos explorado en el capítulo anterior, las coloca encabezando diversas luchas por la reproducción. Asimismo, frente al insoslayable recrudecimiento de los feminicidios, y travesticidios se evidencia que el "mandato de masculinidad" (Segato, 2016) se descarga con mayor violencia contra ciertas marcas y atravesamientos corporales. $Y$ se revela los límites de la institucionalización de las 'políticas de género'. En este sentido, el lema de los movimientos de mujeres en Argentina: "Si nuestras vidas no importan, produzcan sin nosotras", muestra el hartazgo ante la violencia misógina que se relaciona con la explotación y el despojo capitalista (Vega, 2019: 59).

Entonces bien, los sectores del conservadurismo religioso y liberal reaccionan a la potencia feminista que en la última década se han revitalizado a través de un nuevo ciclo de luchas de carácter callejero, juvenil, popular, interclasista, inclusivos (Gago,

\footnotetext{
${ }^{181}$ Siguiendo a Horacio Savori la autora no utiliza el concepto fundamentalismo por que este "ha perdido capacidad analítica para enfrentar las múltiples y proliferantes creencias que habría que agrupar en su seno" (...) "además esta expresión no sólo deja intacto al secularismo, sino que también tiende a "convertir a sus seguidores en un grupo de 'bárbaros', excesivamente alejados del común de los mortales" (Vega, 2019: 55).
} 
2018) que se organizan para frenar la cadena de abusos, agresiones y violencias, a través del "Ni una más", "Ni una menos" y a "Vivas nos queremos". Teniendo una importante continuidad con la marea verde que retoma discusiones transgeneracionales para cuestionar puntualmente los lazos entre violencia, maternidad forzada y derecho colectivo al propio cuerpo.

Ahora bien, uno de los antecedentes del rechazo creciente a lo que se mal denominada "ideología de género" se encuentra en la publicación en 2010 de Ideología de Género: El género como herramienta del poder de Jorge Scala. En este texto la categoría de género aparece definida como un término con diversas acepciones, algunas que en el texto se consideran "legítimas" (como el género aplicado a un objeto, tela, especies) y otras consideradas "ilegítimas", que son "ideológicas", según el autor. En este segundo grupo se circunscribiría la "perspectiva de género" (Scala, 2010: 7) que se propagaría a través de "los medios de masas, y en los ambientes políticos y académicos, de manera mayoritaria" (Ídem).

En este marco, la versión ideologizada del "género" tendría como propósito generar confusión para poder cambiar el "verdadero significado" del término género, para pasar a concebirlo como autoconstrucción libre de la propia sexualidad. Pero, además, este término se articularía con la falsa idea de "igualdad de género" que, siempre según Scala- procura hacer creer que "mujeres y varones seríamos iguales, pero en sentido de idénticos, esto es, absolutamente intercambiables" por tanto, "todo ser humano podría- con autonomía absoluta- elegir su propio género, ya que esto vale tanto para varones como para mujeres" (Ibíd.: 11).

Desde su perspectiva, otros términos ideológicos que participan en el entramado conceptual de la "ideología de género" son el de sexismo, y el de homofobia. El primero es definido como "cualquier límite puesto a la conducta sexual- por ejemplo- prohibir la prostitución, la pornografía, la esterilización voluntaria, la homosexualidad” (ídem). Mientras que el segundo "implicaría tener fobia a la igualdad, entendida como identidad entre los géneros" (Ibíd.: 12). En este punto preciso se manifiesta una apropiación por parte de la reacción neoconservadora de conceptos que han sido acuñados por la teoría feminista. En este sentido, si, por ejemplo, para Lauretis la ideología de género es el mandato heterosexual, y busca dislocarla para generar prácticas y lazos liberadores; para los sectores neoconservadores, la homosexualidad es "lo no natural", una perversión promovida por la "ideología de género". 
A lo largo del libro lo que se propone mostrar Scala es que "la ideología del género" por ser falsa y antinatural (lo que manifiesta un tratamiento de tipo idealista, ya que se concibe a la ideología como "falsa conciencia") sólo puede imponerse de manera totalitaria a través de diversos aparatos de estado, principalmente la institución escolar, y los medios de comunicación ${ }^{182}$. Y desarrolla una serie de "argumentos" para rechazar la "ideología de género", que tiene como blanco central la tesis de que la orientación sexual y la identidad de género no están dados por la biología, sino que son constructos sociales ${ }^{183}$, lo que tendría como efecto: la destrucción de la familia, "núcleo principal de la sociedad" y el "concepto asumido por todos de "familia"; la perversión del lenguaje, para generar confusión mediante la modificación del significado original; el aborto, la pornografía, la hipersexualización, todas prácticas con fines comerciales; y la degeneración sexual y el corte con el binarismo sexual, en consecuencia: el antinaturalismo.

Además, estos sectores reaccionarios afirman que la "ideología de género" a través de los cursos de educación sexual "buscaría promover la experimentación sexual entre los niños", así como implicaría "la eliminación de los derechos de los padres de modo que estos no puedan impedirles a los niños que tengan sexo, educación sexual, anticonceptivos y aborto" (Ibíd.: 13). María das Dores Campos Machado (2018) analiza el fenómeno de rechazo a la "ideología de género" en la sociedad brasilera a partir de la publicación en Brasil en 2011 del libro de Scala bajo el título Ideología de Género: neo totalitarismo y la muerte de la familia. Y advierte que existe una articulación entre "discursos morales, religiosos y científicos" que buscan conservar estructuras que no dan lugar a las disidencias, y que se suponen estáticas como la institución familiar, el lenguaje y el sexo. La pensadora brasilera atiende además a una entrevista que Thácio Lincoln Soares de Siqueira le realiza a Scala en 2012, donde este último ataca a los estudios de género por no ser un campo de estudio científico que sólo buscarían falsear la realidad. Como da cuenta la siguiente cita:

\footnotetext{
${ }^{182}$ A los que él propone llamar "medios de propaganda o medios de masas" ya que la televisión, la radio y los periódicos en realidad, son unidireccionales, y buscan persuadir o propagar determinadas ideas. Un medio de comunicación sería, el teléfono porque intercomunica a dos partes.

183 "El género es una construcción cultural; por consiguiente, no es el resultado causal del sexo, ni tan aparentemente fijo como el sexo..." (Butler: 1990: 6).
} 
una teoría es una hipótesis comprobada experimentalmente. Una ideología es un cuerpo cerrado de ideas, que parte de un presupuesto básico falso -que por ello debe imponerse evitando todo análisis racional-, y entonces van surgiendo las consecuencias lógicas de ese principio falso. Las ideologías se imponen utilizando el sistema educativo formal (escuela y universidad) y no formal (medios de propaganda), como lo hicieron los nazis y los marxistas. [...] el fundamento principal y falso (de la ideología de género) es este: el sexo sería el aspecto biológico del ser humano; y el género sería construcción social o cultural del sexo. Es decir, cada uno sería absolutamente libre, sin condicionamiento alguno, ni siquiera lo biológico, para determinar su propio género, dándole el contenido que quiera y cambiando de género tantas veces como quiera... ${ }^{184}$

(citado por Campos Machado, 2018: 4- 5. La traducción es nuestra)

Desde perspectivas feministas críticas (Vega, 2019) se ha señalado que ya desde la década de los '80, el Vaticano comenzó a enfrentarse al feminismo y su capacidad de influencia en las políticas públicas. En ese sentido, al tiempo que frenaba a los sectores progresistas de América Latina, "facilitaba la entrada del evangelismo integrista" ${ }^{185}$. Mientras que, en la década de los '90 el rechazo a la perspectiva de género presentada en las conferencias de la $\mathrm{ONU}^{186}$ es explícito. Recordemos que el papa Juan Pablo II a

\footnotetext{
184 "uma teoria é uma hipótese verificada experimentalmente. Uma ideologia é um corpo fechado de ideias, que parte de um pressuposto básico falso - que por isto deve imporse evitando toda análise racional -, e então vão surgindo as consequências lógicas desse princípio falso. As ideologias se impõem utilizando o sistema educacional formal (escola e universidade) e não formal (meios de propaganda), como fizeram os nazistas e os marxistas. [...] o fundamento principal e falso (da ideologia de gênero) é este: o sexo serio o aspecto biológico do ser humano; e o gênero seria construção social ou cultural do sexo. Ou seja, cada um seria absolutamente livre, sem condicionamento algum, nem sequer o biológico -, para determinar seu próprio gênero, dando-lhe o conteúdo que quiser e mudando de gênero quantas vezes quiser".

${ }^{185}$ Por integrismo (católicos), se entiende, siguiendo a Geraldina Céspedes (2018), a la idea de "integrar todos los elementos de la sociedad bajo la hegemonía del poder religioso, representado por la jerarquía de la Iglesia católica" (Cfr. Vega, 2019: 53). Lo que se traduce en una actitud rígida y apegada a las doctrinas. Para Vega, la apelación a los principios liberales (cada uno puede pensar lo que quiera), a la que en ocasiones se recurre, puede encajar perfectamente con la aspiración integrista y fundamentalista de estos sectores. La desigualdad deja de ser un problema del orden social instituido (Ibíd.: 53- 54).

${ }^{186}$ En la IV Conferencia Internacional de la Mujer de las Naciones Unidas -realizada en Beijing en 1995se reconocen los derechos reproductivos vinculados con la salud de las mujeres y son definidos como un estado general de bienestar físico, mental y social, y no de mera ausencia de enfermedades o dolencias, en todos los aspectos relacionados con el sistema reproductivo y sus funciones y procesos. En consecuencia, la salud reproductiva entraña la capacidad de disfrutar de una vida sexual satisfactoria y sin riesgos y de procrear, y la libertad para decidir hacerlo o no hacerlo, cuándo y con qué frecuencia. Por otra parte, se reconoció que el sexismo y la homofobia, en sus distintas expresiones, son problemas sociales que exigían la intervención estatal; proliferaron iniciativas legislativas que propendían por el reconocimiento
} 
través de su "Carta a las mujeres" del 29 de junio de 1995 -en ocasión de la realización de la IV Conferencia Mundial sobre la Mujer que tuvo lugar en setiembre de ese mismo año en Beijing- recurrió al discurso naturalista de la división en varón y mujer (contemplando a esta última como copia de María "esclava del Señor”) para rechazar la “ideología de género".

Por su parte, el papa Benedicto XVI ha insistido públicamente en respetar los roles naturales de mujeres y varones, frente a lo que opone la "ideología del género" como la encargada de poner en riesgo la familia, y "la inocencia de los niños". De manera análoga a las declaraciones del papa Francisco quien en 2016 -un año crucial para la implementación de la ley de educación sexual integral en Argentina- sostuvo: “estamos experimentando un momento de aniquilación del hombre como imagen de Dios (...) Hoy en día en los colegios les están enseñando a los niños ¡A los niños! Que todos pueden elegir su género (...)"187. No menos polémicas han sido las palabras del Monseñor Quarracino en torno a los contenidos básicos de la educación sexual, como nos recuerda Ciriza (2007), quien como el resto de la cúpula de la Iglesia Católica sustituye el uso de la palabra género, por la de sexo.

El recurso a la ciencia por parte de grupos conservadores para justificar el rechazo al género, incluyó la mención de las teorías evolucionistas de Darwin y Lamarck, lo que coincide con la "clarificación de los términos ambiguos" (Ciriza, 2007: 16) que Ratzinger propone de la agenda de género, mediante la homologación de la ciencia y de la teología, como hechos de naturaleza, que deben ser protegidos de la contaminación ideológica.

Desde nuestra perspectiva, evaluamos que el ataque al género, pone de manifiesto que este ya no puede ser pensado como un fenómeno meramente cultural, sino como profundamente enraizado en la estructura económica y social. De allí que, una de las principales retóricas para atacar al género sea a través del discurso de la heterosexualidad normativa y obligatoria, que se encuentra en la base de la familia nuclear y del sistema capitalista patriarcal. Además, esta reacción al género revela que el concepto tiene un efecto desestabilizador contra el que arremete el conservadurismo religioso $^{188}$ y liberal a través de discursos contra las reivindicaciones que los

de derechos que tocaban las esferas de la sexualidad y la reproducción; asimismo tuvo lugar una amplia producción de políticas públicas para afrontar las violencias contra mujeres y disidencias sexo- genéricas. ${ }^{187}$ Cfr. discurso en Azerbaiyán el 2 de octubre de 2016.

${ }^{188}$ Durante mucho tiempo la Iglesia Católica en Argentina ejercía su influencia a través de los altos mandos del gobierno de manera más o menos directa. En las últimas décadas, sus estrategias se han 
movimientos de mujeres, feministas y LGTTBIQ ${ }^{189}$ han venido impulsando, principalmente en América Latina, donde las políticas neoliberales impactan (negativamente) con mayor virulencia, y donde la violencia disciplinadora para reproducir la lógica del capital, requiere tanto una batalla contra los cuerpos, pero también por el sentido de las palabras. Sin embargo, evaluamos que los intentos por silenciar y deslegitimar los derechos y avances de género, generan un efecto inverso, que se manifiesta en las calles con más luchas y movilizaciones. Para Ciriza, la ofensiva conservadora agita el fantasma del feminismo como una amenaza del orden político y sexual. Puesto que, "la amenaza de una política directamente edificada sobre la articulación entre cuerpo y política es esgrimida como expresión de un poder capaz de transmutar el orden mismo de la cultura desde sus cimientos" (Ciriza, 2007: 9)

Todos estos avatares manifiestan que la perspectiva de género y los enfoques feministas instituyen nuevos sentidos, contrarios a los valores que los sectores neoconservadores defienden; lo que también permite comprender los ataques contra las ciencias humanas y sociales por los efectos materiales que sus críticas desnaturalizantes conllevan ${ }^{190}$. Por otra parte, y en relación con lo anterior, acordamos con el diagnóstico de Campos Machado, según el cual, existe una apropiación por parte de grupos conservadores -vinculados al cristianismo y al evangelismo- de teorizaciones feministas para volverla en su contra:

En esta contienda cultural y política, la categoría género desarrollada por académicas feministas y adoptada como lenguaje de política pública global por las agencias internacionales; es vista por la Iglesia Católica y segmentos pentecostales como un recurso ideológico que es pernicioso para el orden social. Valorando la dimensión cultural, esta

diversificado y se han fortalecido las que ponen el foco en la sociedad civil. Se trata de una serie de ONG que han crecido y se han multiplicado en Latinoamérica, así como grupos laicos, entre los que se destaca el Opus Dei.

${ }^{189}$ Scala señala que, "el apoyo a la Agenda de género viene de grupos activistas, todos interrelacionados de alguna forma: 1) controladores de la población; 2) libertarios sexuales; 3) activistas de los derechos de los homosexuales; 4) los que apoyan el multiculturalismo; 5) ambientalistas extremistas; 6) progresistas neo- marxistas; 7) posmodernistas o deconstruccionistas. También (...) liberales influyentes en los gobiernos y de ciertas corporaciones multinacionales" (Scala, 2010: 12).

${ }^{190}$ En esta línea, cabe señalar que la Filosofía en Brasil corre el riesgo de ser retirada de los programas curriculares por la amenaza que representa para los defensores del proyecto histórico del capital, la crítica que desnaturaliza el orden instituido. Es el trabajo teórico que acompaña determinadas prácticas de emancipación, de inclusión y de ampliación de derechos el que permitió en parte avanzar concretamente en materia de derechos humanos, de identidad de género, en la no discriminación étnico y racial, en materia de derechos laborales, en la concreción de ciertas políticas públicas. 
categoría tiene un efecto desestabilizador en los principios naturalistas desarrollados por la

ciencia moderna que ayudaron a actualizar el discurso cristiano de la creación de la especie humana por Dios. Los intelectuales cristianos /as que participan en la disputa simbólica en torno

a la categoría de género perciben claramente que, en esta nueva cruzada, el discurso no puede ser sólo de cuño religioso; que tiene que buscar fundamentación en el campo científico donde se desarrolló la argumentación feminista. Y fue la interpretación de la ideología como mistificación o falseamiento de la realidad que estos intelectuales accionaron contra la gramática de género de las feministas. (Machado, 2018: 13. La traducción y la negrita es nuestra) ${ }^{191}$

A propósito de reapropiaciones por parte del conservadurismo religioso de conceptualizaciones del campo de los estudios de género y de la teoría feminista, se ha advertido que el papa Francisco, de manera personal, apela a la "colonización ideológica" (Vega, 2019; Pecheni, 2016) de la naturaleza humana como modo de empatizar con sectores populares desde una perspectiva latinoamericana. Es bajo esta sobrevaloración de "lo natural" que se esencializa la diferencia sexual y se postula como destino natural, la heterosexualidad y la maternidad. De allí la importancia del carácter subversivo del concepto de "género" que, desnaturaliza y combate el biologicismo que clasifica dicotómicamente de acuerdo al sexo biológico.

Sin embargo, si bien la incorporación del concepto de género en la teoría feminista permite avanzar contra el determinismo biológico, coincidimos con Ciriza cuando advierte que se produce una disolución del carácter político del género cuando se estabiliza y neutraliza. Proponemos en este sentido, trazar genealogías políticas del género, pero antes será menester hacer un recorrido en torno a la singularidad de este concepto "viajero" (travelling concept).

\section{Genealogías del género}

191 "Nesta contenda cultural e política, a categoria gênero desenvolvida por acadêmicas feministas e adotada como linguagem de política pública global pelas agências internacionais é vista pela Igreja católica e segmentos pentecostais como um recurso ideológico que é pernicioso para a ordem social. Valorizando a dimensão cultural, esta categoria tem um efeito desestabilizador nos princípios naturalistas desenvolvidos pela ciência moderna que ajudaram a atualizar o discurso cristão da criação da espécie humana por Deus. As/os intelectuais cristãs/aos que participam da disputa simbólica em torno da categoria de gênero percebem claramente que, nesta nova cruzada, o discurso não pode ser só de cunho religioso; ele tem que buscar fundamentação no campo científico onde a argumentação feminista foi desenvolvida. E foi a interpretação da ideologia enquanto mistificação ou falseamento da realidade que estes/as intelectuais acionaram contra a gramática de gênero das feministas". 
... las perspectivas feministas si bien, ligadas a diferentes tradiciones politicas y organizativas, compartían un suelo común: hicieron visibles las relaciones entre producción y reproducción humana, entre condiciones estructurales y división sexual del trabajo, entre teoría y práctica, entre cuerpo y politica, entre trabajo productivo y reproductivo, entre

patriarcado y capitalismo. (Ciriza, Apuntes para una crítica feminista de los atolladeros del género)

El concepto de género es utilizado por primera vez por el Dr. Money, especialista en psiconeuroendocrinología, que en su tesis doctoral en 1947 utiliza el término para dar cuenta del estado social y personal de un individuo, independientemente de sus órganos sexuales. La identidad de género, aparece vinculada así, al aspecto psicológico del individuo.

Luego, entre los '40 y '60, el concepto es utilizado en el campo de las ciencias sociales y adquiere reflexiones "culturales" en torno a los significados de la diferenciación sexual. En el marco de las investigaciones antropológicas se establece que el sexo estaba anclado a la biología, mientras que el género era un comportamiento vinculado a la construcción social a partir del marco cultural de la diferencia sexual, pero no determinada inmediatamente por ella. Tal como afirma Levi- Strauss (1949) al postular una teoría del nacimiento de la cultura basada en la estructura -universal y fijadel intercambio de mujeres por parte de los hombres, a través del cual los hombres "salen del estado de naturaleza" e inauguran la sociedad.

El análisis de Levi- Strauss influyó fuertemente sobre las reflexiones de Simone de Beauvoir que, en El segundo Sexo (1949) afirma que la subordinación sistemática de la mujer en relación al hombre se vincula a la supuesta "esencia femenina" construida sobre la base de una serie de características atribuidas a la mujer. Supuesto esencialista frente al cual Beauvoir contrapone que "la mujer no nace, se hace", subrayando el carácter social, histórico y culturalmente construido de la "mujeridad". Dando lugar, por otra parte, a la distinción entre sexo y género, que tiene una fuerte influencia sobre el feminismo de la segunda ola.

En esta dirección, en 1974 Gale Rubín postula que las raíces de la opresión femenina, están vinculadas a la pertenencia al sexo biológico mujer; es decir, a la diferencia sexual anatómica de la mujer en relación al hombre. Frente a la pertenencia "rígida" y no elegida del sexo, la identidad de género aparece vinculada a la construcción social y cultural en un momento histórico concreto; por tanto, con potencialidad de ser modificada y elegida libremente. Esta línea teórica se caracteriza por problematizar los lazos afectivos, la construcción de la subjetividad, y la distinción 
entre público/ privado; realizando fuertes críticas al psicoanálisis -principalmente en su formulación del "estadio del espejo"- por haber proporcionado una visión naturalista y esencialista en la constitución de una jerarquía en el proceso de formación de la identidad de género.

En la década de los años noventa, tanto el pensamiento lesbiano -mediante el cuestionamiento del binomio conceptual de la diferencia sexual-, y la teoría queer mediante el cuestionamiento de la identidad de género y su nexo con la sexualidad-; logran extender el concepto de género a lesbianas, gays, trans travestis, maricas e intersex $^{192}$. El género insiste así, en el carácter fundamentalmente social de las distinciones en el sexo, en detrimento del determinismo biológico implícito en el uso de términos como los de "sexo" y "diferencia sexual". Judith Butler ([1990] 2001) aportó de manera significativa a la disputa en torno al género e incluso inspiró la emergencia local de los "estudios queer" al postular la performatividad del género: el género como como un conjunto de actos, gestos y comportamientos que crean la identidad de género. Siguiendo a Foucault, desde este posicionamiento se comprende que, son las relaciones de poder las que forman el cuerpo, disciplinándolo, modelándolo, en conformidad con un género. Es decir que el cuerpo también es constreñido por el discurso, al punto que el cuerpo ya no es un lugar de anudamiento de la identidad de género del sujeto, sino el producto de relaciones de poder diseminadas.

Las críticas a esta tesis, no tardaron en llegar, y estuvieron centradas puntualmente en el sesgo voluntarista que supone la afirmación de que la identidad de género se construye a través de la reiteración de actos performativos ${ }^{193}$ de un sujeto, "ya bastante martirizado por tres décadas de postmodernismo" (Arruzza, 2010: 136). En esta línea, Ciriza afirma que, si bien es cierto que el sexo remite a los anclajes biológicos, también hay que reconocer que remite a las distintas experiencias del cuerpo, que pueden quedar "diluidas" en las tramas discursivas del tratamiento del género desde una perspectiva que enfatiza el papel del lenguaje. Para Ciriza, existe una

\footnotetext{
${ }^{192}$ Monique Wittig (1992) por ejemplo, sostiene que la ideologia de la diferencia sexual se funda en la heterosexualidad obligatoria y funda los roles de varón- mujer. De hecho, hombres y mujeres representan dos clases antagónicas dentro de la norma instituida de la heterosexualidad, con el fin de sostener la división en clases sexuales, reproduciendo las condiciones para la explotación de las mujeres. Las lesbianas no son mujeres, ya que, al romper el contrato heterosexual, han huido de la clase a la que estaban adscritas. Son pues "no-mujeres" y su condición abre la vía a la liberación del resto de las mujeres.

${ }^{193}$ En Cuerpos que importan (1993) Butler responde que, puesto que la performatividad no es un juego ni una escena teatral, no es posible pensar que las identidades puedan construirse a libre voluntad.
} 
despolitización en el uso filosófico del concepto de género; vinculada, al abandono de una perspectiva materialista en torno a la corporización de las opresiones y a la materialización intrínseca de los cuerpos, que "por sólido no puede desvanecerse en el aire" (Ciriza, 2007: 15- 16).

En efecto, en los tempranos años noventa del siglo pasado, la categoría de género es incorporada a la academia latinoamericana, principalmente, para reemplazar a la categoría de "mujer", entendida de una manera monolítica, homogénea y esencialista. Frente al "reduccionismo" a un sujeto- mujer, el concepto de género tendría el objetivo de avanzar contra el determinismo biologicista, y ampliar el espectro de opresión a otras relaciones en las cuales se construían los vínculos entre los géneros cruzados por el poder. Puesto que la noción "enfatizaba también el aspecto relacional de las definiciones normativas de la feminidad" (Scott, 1993: 18). En este sentido, "aquellos que se preocuparon porque los estudios de la mujer focalizaron demasiado estrecha y separadamente a la mujer, usaron el término género para introducir una noción relacional en nuestro vocabulario" (Ídem.).

Sin embargo, con la incorporación del concepto de género en la academia latinoamericana, una palabra que "parece sonar más objetiva y neutral que la de 'mujer' y que encaja mejor en la terminología científica de las ciencias sociales al separarse de la "estridente" política del feminismo" (Ibíd.: 21) se produce un borramiento del sujeto político en cuestión. Puesto que, "mientras que el término 'historia de la mujer', proclama su política afirmando que las mujeres son sujetos históricos válidos, el de 'género', no parece tan amenazador, porque las incluye, pero no las nombra” (Ídem.) ${ }^{194}$.

Este proceso de despolitización conceptual se vincula desde nuestra perspectiva a que se estabiliza una noción del concepto demasiado abarcativa: "una manera primaria de significar las relaciones asimétricas de poder" (Ibíd.: 35), que si bien permite visibilizar el carácter social del sexo y del género es una propuesta sumamente amplia que -"a pesar de la complejización de los estudios de género, en el atravesamiento con los postestructuralismos y los estudios queer"(Campagnoli, 2011: 110)- se simplifica y neutraliza. La masificación acrítica del concepto, ha tenido efectos de simplificación y neutralización; en última instancia, reinstauran una perspectiva binaria excluyente que escinde teoría y práctica. De manera que, si la incorporación del concepto "género" en

\footnotetext{
${ }^{194}$ De manera análoga a lo que ocurre con el reemplazo de la categoría de "raza" por el de "etnia", proceso que produjo la naturalización de un "racismo sin razas" (Stolcke, 2000; Tijoux y Palominos Mandiola, 2015).
} 
la teoría feminista se proponía superar el carácter excluyente del concepto monolítico y homogéneo de mujer, como bien se ha criticado desde hace más de dos décadas desde los márgenes del feminismo hegemónico; ha tenido procesos de mera formalización vinculados a su estabilización conceptual.

No obstante, advertimos fenómenos conceptuales de dislocación que evitan que, a pesar de las tentativas de estabilización de los conceptos, que ponen en riesgo su capacidad analítica y política, estos a nivel práctico muestren sus núcleos políticos. En el caso del concepto de género, hay un núcleo político que se manifiesta toda vez que el concepto tiende a estabilizarse. Como ocurre con el concepto de género como construcción social que vuelve a desestabilizarse a partir de la publicación en 2010 de El Calibán y la bruja de Federici. Ya que allí Federici reintroduce la problemática de los sujetos- mujeres ${ }^{195}$, desposeídas de sus cuerpos y sus saberes, a través del mayor sexocidio de la historia, entendido como un acontecimiento fundacional del sistema capitalista $^{196}$. Lo cual nos conduce al segundo síntoma: la politicidad del género se manifiesta desbordando el terreno teórico para hacerlo en el plano de la acción colectiva y la esfera pública. Como se exhibe en el fenómeno ideológico discursivo de rechazo a "la ideología de género".

Ahora bien, frente a la despolitización del concepto de género, proponemos escudriñar el concepto en perspectivas materialistas que puedan anudarlo con "sus encarnaduras", y sus opresiones concretas y situadas; tanto como con las tradiciones de luchas políticas, y con las condiciones materiales de existencia que rigen estas luchas. Acordamos con Federici (2018) en este sentido, en la necesidad de adoptar una perspectiva interseccional que integre la lucha de clases como una dimensión ineludible, pero que también visibilice la complejidad que representa la articulación de los diferentes sistemas de opresión -como el patriarcado, el capitalismo y el racismo- y a las simultáneas y múltiples imbricaciones del género con el sexo, la raza y la clase.

En este sentido, Ciriza sugiere atender al hecho de que el feminismo como discurso político, ligado a las demandas del sujeto- mujer data de principios del siglo

\footnotetext{
${ }^{195}$ Para Federici la "historia de las mujeres" es la "historia de las clases" y la pregunta que debemos hacernos es si se ha trascendido la división sexual del trabajo que ha producido ese concepto en particular. "En caso de que la respuesta sea negativa (...) entonces 'mujeres' es una categoría de análisis legítima, y las actividades asociadas a la 'reproducción' siguen siendo un terreno de lucha fundamental para las mujeres" (Federici, 2010: 27).

196 Sin embargo- contra las lecturas reproductivistas y pesimistas- cabe destacar que, el ataque sistemático sobre la reproducción y contra las mujeres, no ha dejado de desatar nuevas luchas por el control de los medios de producción y subsistencia.
} 
XIX $^{197}$, pero la construcción de una perspectiva teórica -los “estudios de la mujer"irrumpe más tarde, en los años '60 y ' $70^{198}$ de la mano de los movimientos emancipatorios de mayo del '68, y del movimiento negro de Estados Unidos. Los Black's Studies, en esta dirección, al tiempo que luchaban contra el sexismo y el racismo; buscaban en el plano teórico encontrar formas específicas de explicar los procesos de explotación vinculada a la pertenencia étnico- racial y al sexo biológico, anticipando un abordaje del género desde una perspectiva interseccional.

El concepto de interseccionalidad apareció conceptualizado por primera vez en 1989 en un artículo de la abogada feminista negra Kimberlé Crenshaw (1991) ${ }^{199}$; sus antecedentes más importantes se encuentran en las feministas negras de los años '70. La colectiva Combahee River Colective formuló una crítica "interseccional" a los movimientos de liberación, en el marco de la segunda ola feminista, por comprender la categoría "mujer" de manera homogénea. Frente a esta pretensión de universalidad de un feminismo hegemónico (de mujeres blancas, de clase media) las mujeres negras pudieron establecer que las formas de opresión experimentadas por las mujeres, se vincula a cómo el género se combina y se entrecruza con la raza y la clase. Con lo cual, rechazaron que "los intereses de clase de las mujeres privilegiadas, especialmente blancas, esté por encima del resto de las mujeres" (hooks, 2000: 84), lo cual ha sido profundizado desde los feminismos latinoamericanos, decoloniales y disidentes.

En otras palabras, proponemos hacer un tratamiento del género, comprendido como parte de un entramado material complejo, desde perspectivas críticas que eviten eludir el carácter político que es inmanente a la crítica feminista, y que es lo que permitió visibilizar y desnaturalizar las múltiples violencias y opresiones sufridas por sexo, género, pero también por raza, clase, edad, diversidad funcional, entre otras instancias de diferenciación social. Por ello es fundamental reconceptualizar el "género"

\footnotetext{
${ }^{197}$ Ciriza señala que se trata precisamente de la época de la que habla Marx en el Manifiesto Comunista (1848). El feminismo se constituye como movimiento político en la brecha que ofrece el discurso burgués de la igualdad abstracta de todos los hombres ante la ley (Ciriza, 1994: 43).

${ }^{198}$ En este periodo histórico, a medida que las movilizaciones feministas de la segunda impactan en las academias, muchas feministas (incluidas las socialistas y las marxistas), situadas dentro del entramado binario epistemológico de naturaleza/cultura, se apropian de la distinción sexo/género para defender la primacía de cultura-género sobre biología-sexo en una multiplicidad de debates en Europa y en los EEUU. (Campagnoli, 2011).

199 Allí señalaba que el tratamiento por separado de las discriminaciones de raza y género, como "categorías mutuamente excluyentes de la experiencia y el análisis", tenía consecuencias problemáticas para la jurisprudencia, para la teoría feminista y para las políticas antirracistas. Por ese motivo proponía "contrastar la multidimensionalidad de la experiencia de las mujeres negras, frente al análisis de un solo eje que distorsiona estas experiencias".
} 
inscribiéndolo en líneas teóricas que posibiliten comprenderlo desde su complejidad e interseccionalidad con otras instancias: de clase, raza, sexualidad, espacio, edad, las que confluyen, se superponen y se imbrican construyendo posiciones políticas de inclusión, exclusión y disidencia (González Ortuño, 2016; Vigoya Viveros, 2016). Sin embargo, hay que considerar también, siguiendo miradas críticas del concepto que, la interseccionalidad se transformó en una palabra de moda en congresos y simposios.

Bajo esta línea de análisis, la interseccionalidad se estabiliza de manera análoga a lo que ocurre con el concepto de género en los ámbitos académicos que ha tenido un efecto negativo: la pérdida gradual de su politicidad y crítica inherente "que lo ha llevado a abandonar buena parte de sus postulados políticos más éticos y revolucionarios" (Curiel, 2010, p. 73).

Para finalizar, puesto que el género es una estructura de diferenciación fundamental, que establece jerarquías en articulación con otras instancias de la estructura social, proponemos intervenir filosóficamente en la problemática de la articulación entre ideología y género. Reconociendo que nuestro terreno de intervención "es un territorio ya ocupado por otros discursos", de allí que propongamos el trazado de genealogías feministas críticas, y desde el sur geopolítico; así como la inscripción del concepto en perspectivas materialistas, interseccionales y situadas.

La interpelación y el desafío quedan planteados, y es lo que configura nuestras futuras investigaciones. 


\title{
Conclusiones preliminares
}

\author{
Estamos enraizadas en el lenguaje, casadas, nuestro ser son palabras. El \\ lenguaje es también un lugar de combate. El combate de los oprimidos respecto al \\ lenguaje para recuperarnos a nosotras mismas — para rescribir, reconciliar, renovar. \\ Nuestras palabras no carecen de importancia. Son un acto — de resistencia. El \\ lenguaje es también un lugar de combate \\ (bell hooks, El feminismo es para todo el mundo)
}

La tercer y última parte de este trabajo titulada "Ideología y género" se estructuró en torno a la "ceguera de género" de Althusser -que implicó un rodeo en torno a la "ceguera de género" de Marx- para dar lugar a una nueva problemática: la de la articulación entre ideología y género.

En este sentido, realizamos una lectura sintomática del lapsus althusseriano en torno a la cuestión de la producción de subjetividades generizadas, entendiendo que el género es una estructura de diferenciación y jerarquización primaria que se entrecruza e imbrica con otras dimensiones sociales y políticas- así como leímos críticamente su abandono de una concepción materialista de los discursos.

En esta dirección, exploramos perspectivas feministas contemporáneas que han abordado la compleja relación entre ideología y género partiendo de la premisa de que la vida social está generizada, mostrando la efectividad de los discursos en los procesos de generización. Entre estas se encuentra la propuesta de Gale Rubín, que explora las condiciones bajo las que se producen los "sujetos con género" en el marco del sistema sexo/ género, entendido como estructura heterosexual dominante. Frente a la "ceguera de género" de Marx, Rubín plantea que los mecanismos de parentesco y el familiar son productores de sujetos generizados -que se reconocen como varones o mujeres- y que permiten la reproducción de las relaciones dicotómicas y jerárquicas dentro del sistema sexo/género, como parte de la división sexual del trabajo.

Hemos evaluado que, si bien el esquema sexo/ género, fue ampliamente discutido por implicar un reduccionismo, y por quedar supeditado a un esquema dicotómico y jerárquico sin lugar a las disidencias sexo- genéricas (Butler, 2007); creemos que el esfuerzo de Rubín de analizar los vínculos entre las relaciones de poder sexo/género que subordinan a las mujeres con los procesos estructurales del desarrollo capitalista en términos de división sexual del trabajo, ha sido un aporte crucial para la teoría feminista, y una "piedra de toque" fundamental para desarrollos y discusiones posteriores.. 
Hemos examinado, asimismo, los análisis de las feministas marxistas y las feministas materialistas quienes analizan los efectos opresivos que el sistema capitalista heteropatriarcal efectúa principalmente sobre las subjetividades feminizadas. Hemos señalado que mientras que las primeras le otorgan primacía a la estructura capitalista; las segundas, le otorgan primacía a la estructura patriarcal.

Al enfocarnos específicamente en lectura crítica de Silva Federici, hemos examinado que esta analiza las violencias contra "los sujetos- mujeres" en el periodo de transición del feudalismo al capitalismo, destacando la centralidad de los discursos, entendidos como materiales y con una eficacia concreta en los procesos de explotación y apropiación de los cuerpos (y los saberes encarnados) de las mujeres.

En este marco, los discursos naturalistas y esencialistas legitiman las prácticas de la violencia misógina, y las opresiones contra las mujeres y contra las subjetividades feminizadas. Federici muestra que, los discursos que homologaron a las mujeres con la naturaleza, con la corporalidad y con lo "más bajo" (dentro de las dicotomías jerárquicas modernas) posibilitaron las condiciones para que estas sean disciplinadas y puestas bajo el control "masculino" y del Estado; así como constituidas en bienes comunes. obligadas a procrear y a realizar tareas domésticas que no categorizaban como trabajo asalariado.

Bajo este análisis, se argumenta que el ocultamiento de la explotación de las mujeres y también de los sujetos coloniales- es lo que ha permitido al capitalismo acrecentar sus ganancias y acumular trabajo femenino "esclavo" a partir del marco legal de la división sexual del trabajo en público/privado. División en la que, como hemos examinado siguiendo a Federici, el primero le queda asignado a los hombres, que trabajan por un salario; mientras que las mujeres quedan confinadas al ámbito privado y son obligadas a realizar trabajo doméstico no remunerado.

Por último, a propósito de la crítica de Federici a la ceguera de género de Marx, hemos evaluado que su análisis nos permite conectar la centralidad de los discursos para legitimar opresiones y violencias contra las subjetividades feminizadas y sexodisidentes en nuestra actualidad. En este sentido, hemos argumentado que existe un nexo entre la matanza de brujas en el periodo de transición del feudalismo al capitalismo y la "guerra actual contra las mujeres" desatada por los "voceros del proyecto histórico del capital" -que mediante prácticas y discursos específicos- se proponen silenciar y aniquilar a los sectores que representan una amenaza para mantener el sistema capitalista heteropatriarcal. 
Para argumentar nuestra hipótesis, hemos examinado que es a través de una retórica antigénero que sectores neoconservadores y neoliberales en nuestra región -sea en el "nombre de Dios" o "por el bien de la familia"- intentan demonizar, y subsidiariamente, deslegitimar, lo que representan como “ideología de género". Para ello, exploramos supuestos, filiaciones y consecuencias teóricas y prácticas de esta formación ideológica discursiva. Además de destacar que la expresión "ideología de género" es acuñada en la teoría feminista y apropiada de esta para volverla en su contra.

Como ocurre con la formulación que hace Lauretis para analizar los procesos específicos que operan en los mecanismos de producción de subjetividades generizadas. Lauretis, retoma explícitamente la tesis althusseriana de la interpelación ideológica para explicar los procesos complejos y diferenciales de producción de subjetividades generizadas en el marco de la ideología del género. Exhibimos que, en el marco del análisis de Lauretis, la generización es pensada como un proceso de subjetivación/ sujeción específica de la ideología de género, que produce sujetos generizados.

Así como examinamos que, la mirada aguda de Lauretis, ha permitido también, abonar razones para reconocer críticamente las limitaciones que supone para la teoría feminista la circunscripción del género como diferencia sexual, donde el género tiene la función de constituir individuos como varones y mujeres -en una dicotomía jerárquicapara que funcionen en la estructura heteronormativa. Contra la ideología de género, y contra las representaciones de género que colocan a la mujer en el lugar de la alteridad, Lauretis señala la posibilidad de agenciamiento y de ruptura con los discursos hegemónicos, desde una posición discursiva excéntrica. De manera que concibe al género como un efecto de representación y como un exceso de la representación, simultáneamente; es decir, con capacidad disruptiva y desestabilizadora.

Por otra parte, hemos argumentado que:

a) la apropiación que desde sectores neoconservadores y neoliberales se ha realizado de la ideología de género, para tergiversarla y anularla constituye una restitución de un tratamiento de tipo idealista de la ideología, ya que se la entiende como falsa conciencia, mistificación de la realidad. Por lo cual, es potente trazar analogías y articular los conceptos de "ideología" y de "género". Ambos con tensiones, y recorridos sinuosos.

b) a nivel práctico- político, el fenómeno ideológico discursivo de rechazo a la “ideología de género" manifiesta el núcleo político que tiene el concepto de género, con potencialidad para desestabilizar las estructuras que reproducen las condiciones 
materiales de explotación y de opresión. Con lo cual, los ataques al "género" revelan que el estatuto de esta cuestión no es marginal, sino que es central en la estructura del capitalismo patriarcal; de allí que se encuentre en el centro de la escena política.

c) a nivel teórico- conceptual, toda vez que el concepto de género ha tendido a estabilizarse, se producen rupturas teóricas e inflexiones que vuelven a desestabilizarlo. Como ocurre con la definición consolidada del género como "construcción social", o como diferencia sexual, refiriendo a un sujeto mujer monolítico, eurocentrado, blanco, burgués y de clase media. Lo que ha dado lugar a críticas desde el margen del feminismo hegemónico, y a la alternativa superadora de escudriñar al género en una perspectiva interseccional e inclusiva, que atienda a múltiples opresiones entrecruzadas e imbricadas. Hemos manifestado que es necesario repolitizar el concepto de género mediante el trazado de genealogías feministas críticas y desde el sur; así como de recomplejizarlo, inscribiéndolo en perspectivas materialistas, inclusiva se interseccionales, que comprendan la clase, el género, la sexualidad y la pertenencia étnico/ racial y etaria como parte de un sistema de dominación múltiple e imbricado.

Avanzar en esta dirección, configura el recorrido de nuestras futuras investigaciones. 


\section{CONCLUSIONES FINALES}

El objetivo fundamental de este trabajo ha sido examinar el complejo mecanismo de subjetivación/ sujeción de la interpelación ideológica, la función central de la ideología en el marco de la reformulación del concepto propuesta por Althusser. Examinamos en este sentido que, la formulación althusseriana de la práctica de la interpelación ideológica constituye una respuesta a una pregunta no planteada desde marcos idealistas: ¿cómo se constituyen los individuos en sujetos? Con lo cual Althusser repone un silencio teórico por parte de los abordajes que suponen al "sujeto" como categoría fundamental.

En esa dirección, al inicio de este trabajo señalamos que, la inscripción de la ideología en una perspectiva materialista establece una importante demarcación con los tratamientos de la ideología de tipo idealistas que la ubican en la dimensión de la interioridad subjetiva. Como hemos analizado- en el marco propuesto por Althusser, la ideología existe materialmente a través de prácticas y discursos, que tienen la función práctica y social de garantizar el dominio de la ideología de las clases dominantes.

Mostramos que en este nuevo marco el sujeto (ideológico) es comprendido como un efecto de la práctica de la interpelación ideológica que -articulada con la estructura social- tiene por función central garantizar que los individuos ocupen los lugares que se ha dispuesto para ellos dentro de una formación social concreta. Con lo cual evaluamos que, la materialidad de la ideología involucra también la materialidad del sujeto, en tanto efecto de las estructuras sociales; así como implica comprender que ambas categorías (las de ideología y la del sujeto) se encuentran en una relación de inmanencia.

Entonces bien, bajo el interés de indagar en qué consiste la práctica de la interpelación ideológica, hemos analizado que el pensamiento de Althusser -inscripto en una reflexión filosófica contemporánea- cuestiona la idea de un sujeto centro, para otorgarle primacía a las estructuras y los procesos sociales que lo anteceden. Mostramos en este sentido que, el carácter derivado del sujeto (en contraposición al del sujeto como fundamento) es transversal en la intervención materialista althusseriana, y adquiere diversas formas. Entre estas se encuentra la tesis del antihumanismo teórico, una tesis radical que Althusser postula (siguiendo en ello las estrategias de "curvar el bastón" y de "pensar en los extremos" de Lenin y de Maquiavelo, respectivamente) para trazar una demarcación con la ideología del humanismo teórico que obstaculiza, según 
Althusser, dimensionar la novedad del descubrimiento de Marx y enmascara las razones profundas de la crisis del marxismo.

Hemos analizado que, para Althusser la ideología humanista responde a los intereses de la burguesía en ascenso y tiene la pretensión teórica de explicar la sociedad y la historia, partiendo de la esencia humana: de un sujeto al que se supone libre, soberano y que actúa voluntariamente, según su conciencia. Frente a lo cual, Althusser propone la tesis del antihumanismo teórico -heredera del antihumanismo de Spinozaque opera en articulación con otras formulaciones que le son subsidiarias como la del proceso sin sujeto ni fines, en la que se rechaza, la categoría de sujeto entendido como Origen, Fin y Fundamento. Hemos señalado que, con la postulación de la historia como un proceso sin sujeto ni fines, Althusser pretende combatir las interpretaciones ideológicas como la del historicismo que identifica la historia real con la historia teórica del pensamiento de Marx.

En cuanto a las lecturas ideológicas del pensamiento de Marx y del tratamiento idealista de la ideología, examinamos que, de acuerdo con la lectura de Althusser, este tipo de abordaje es subsidiario del tratamiento tradicional del conocimiento, de tipo empirista; donde este último es concebido como el producto de una relación preestablecida entre sujeto y objeto. Frente al cual Althusser propone comprender el conocimiento como el resultado de un proceso de producción que no tiene a un sujeto como agente central, sino que se produce mediante mecanismos de la práctica teórica, que ocurre a través de tres generalidades (herederas de los tres tipos de conocimiento en Spinoza). Pero este proceso se da "en el pensamiento" es decir, no se deduce del objeto real, no es su fenómeno ni está contenido en su interioridad, sino que es un objeto distinto. Tal como Spinoza distingue entre la idea de círculo y el círculo real; y tal como Marx, distingue entre el objeto de conocimiento y el objeto real.

Efectivamente, en el nuevo marco, el proceso de conocimiento no es el de un sujeto (centro) que constituye la realidad; sino que es el resultado de un proceso sin sujeto; en coherencia con un posicionamiento materialista que postula el estatuto derivado del sujeto (ideológico) como efecto de los mecanismos que reproducen la formación social. En este sentido, el descentramiento del sujeto y la tesis del proceso sin sujeto, refuerzan el rechazo de concebir un sujeto originario de sus necesidades (homo economicus) de sus pensamientos (homo rationalis), de sus actos y de sus luchas (homo moralis, juridicus et politicus).

Hemos mostrado asimismo que, el rechazo al sujeto comprendido como centro 
se vincula estrechamente con la concepción de las formaciones sociales entendidas como complejos estructurados en las que se articulan múltiples instancias -determinadas en última instancia por la economía- en las cuales los sujetos no son constituyentes, sino efectos de las relaciones de producción. En esta dirección, hemos examinado que, la concepción de la sociedad como un todo complejo estructurado con dominante y de la determinación en última instancia por la economía, son centrales para comprender el funcionamiento de la ideología con existencia material en prácticas y discursos que reproducen las relaciones de producción. Puesto que, en el análisis propuesto por Althusser, existe una relación necesaria entre el sujeto y la ideología, cuya estructura de la interpelación- garantía es la que produce el efecto de subjetividad ideológica.

Hemos explorado en este sentido que, la identificación del carácter ideológico de la noción de sujeto, parte ahora de la pregunta por sus efectos políticos, con lo cual Althusser redobla la perspectiva histórica que involucra la tesis de que la lucha de clases es el motor de la historia. Examinamos que, la concepción de la historia como un proceso sin sujeto - expuesta centralmente en los textos de autocrítica- y la teoría de la ideología desde bases materialistas, encuentran su conexión en la idea de que la ideología es la forma en la que hombres y mujeres se constituyen para formar parte de un proceso del cual no son constituyentes. Hemos analizado a su vez que, en sus textos de autocrítica, Althusser rectifica su distinción tajante entre ciencia e ideología para reconocer rupturas epistemológicas diversas (al diferenciar entre ideologías teóricas, ideologías prácticas, etc.); y rectifica su posición teoricista al plantear la politicidad de la práctica teórica. Analizamos que es en este marco que Althusser propone una nueva práctica de la filosofía: como lucha de clases en la teoría.

Por otra parte, hacia el final de la primera parte, exploramos que en los textos conocidos como los textos del "último Althusser"- existe una continuidad (no monolítica, sino, rectificada, con rodeos, recomienzos, y polémicas, propias del filosofar althusseriano) de tesis materialistas transversales de su intervención filosófica. Hemos señalado también que, entender esta particularidad de la práctica filosófica propuesta por Althusser, es una comprensión muy distinta de aquellas concepciones que interpretan virajes y cortes en el "último Althusser", respecto de sus posicionamientos "clásicos", como si hubiesen "cortes epistemológicos" al interior de la propia producción althusseriana.

En esta línea, hemos analizado que, la lectura filosófica que propone Althusser es una práctica de lectura materialista, que busca dar cuenta de determinados conceptos 
“científicos" de la teoría marxista y con ello reemplazar las lecturas ideológicas que obturan su novedad. De allí la centralidad que tiene la lectura filosófica del pensamiento de Marx, propuesta por Althusser; porque implica producir una serie de lecturas dobles a partir de las discontinuidades del discurso de Marx, para dar lugar a problemas no planteados. Bajo este protocolo de lectura, Althusser plantea un corte epistemológico en el pensamiento de Marx, entre una problemática ideológica y una problemática científica; esta última, expresada en la invención de un método materialista dialéctico y en la concepción de la contradicción sobredeterminada, completamente distinta a la hegeliana.

Examinamos que para Althusser, lo que ocurre en el caso del desarrollo del pensamiento de Marx, es un "cambio de terreno", una inscripción de los problemas filosóficos en un marco materialista. Examinamos que esta demarcación es realizada por Althusser a partir de una lectura sintomática que distingue entre una problemática ideológica en el pensamiento del joven Marx, y una problemática científica a partir de La ideología alemana, en la que -como hemos mostrado- Marx según Althusser, rompería con su concepción ideológica anterior. Evaluamos que la ruptura de Marx no es total, ya que persisten resabios mecanicistas y positivistas, en el fondo idealistas en esta obra de 1845. Ya que allí la ideología es presentada como una ilusión, como puro sueño; aunque Marx postula una tesis materialista fundamental según la cual "no es la conciencia la que determina la vida, sino la vida la que determina la conciencia" (Ibíd.: 26).

Mostramos que Althusser ve en estas tesis de Marx, el inicio de una ruptura teórica con el abordaje idealista de la ideología, y propone inscribir el concepto en bases materialistas. En rechazo al abordaje ideológico de la ideología, que ubica las concepciones y las ideas del hombre en el ámbito de la conciencia; para Althusser la ideología tiene muy poco que ver con la conciencia, sino que funciona de manera profundamente inconsciente, aun cuando parece reflexiva, como ocurre en el "materialismo de lo imaginario" de Spinoza.

Mostramos que, en la intervención de Althusser existe una transversalidad de tesis materialistas centrales, que toman formas diversas a lo largo de su obra, como lo son: a) la propuesta de una práctica filosófica de la lectura; b) la crítica al abordaje idealista de las filosofías del sujeto (antihumanismo teórico) y el rechazo a toda idea de Origen y de génesis; c) el rechazo al tratamiento idealista de la ideología; y d) la propuesta de causalidad estructural y de contradicciones sobredeterminadas; e) la 
propuesta de las formaciones sociales como estructuras complejas con una multiplicidad de instancias articuladas y determinadas en última instancia, en las que el "sujeto" no ocupa más que un lugar secundario. Y f) la propuesta de una nueva práctica filosófica, en la que existe una primacía de la práctica por sobre la teoría en un campo de batalla (Kampfplatz).

Recapitulando: en la primera parte, "La ideología desde una perspectiva materialista", analizamos la lectura de Marx por Althusser, la que, bajo el interés de renovar el marxismo, implicó desmontar las lecturas humanistas -por entonces hegemónicas- que obturaban dimensionar la magnitud del descubrimiento científico de Marx. Examinamos que, tal descubrimiento se manifiesta, en el estado latente de determinados conceptos, a los que Althusser les da existencia al formularlos explícitamente como el de causalidad estructural (heredero según la lectura althusseriana, de la causalidad inmanente de Spinoza); el de determinación en última instancia, y el de contradicción sobredeterminada. Por tanto, mostramos que existe un hilo vertebrador en la obra althusseriana: su posición materialista en filosofía que se manifiesta en el rechazo transversal del Sujeto como Origen, Fin y Causa. Evaluamos que este posicionamiento de Althusser concuerda con su propósito de recomenzar la problemática materialista en filosofía entendida como lucha en un campo de batalla. Y consecuentemente, con su propósito de combatir los tratamientos idealistas entendidos como un obstáculo para dimensionar las potencialidades de la teoría de Marx.

En la segunda parte titulada "Ideología y subjetivación" profundizamos el análisis de la reformulación del concepto de ideología propuesto por Althusser y examinamos que la ideología entendida desde su materialidad tiene la función central de interpelar a los individuos como "sujetos". Puesto que, en el marco del sistema de producción capitalista- que se encuentra en profunda imbricación con la estructura social- la ideología debe responder a las demandas de las clases dominantes. En este sentido, exhibimos que Althusser argumenta que la ideología constituye una estructura esencial en la vida histórica de las sociedades, a través de su función práctica y social.

Ahora bien, hemos explorado que, de manera transversal, existe un énfasis colocado por Althusser en la función práctica y social de la ideología, que toma una forma precisa en Ideología y aparatos ideológicos del Estado -como lo analizamos en la segunda parte de este trabajo- donde Althusser plantea una articulación fundamental entre ideología y estructura social a través de las prácticas que prescriben los AIE. Y entre ideología y estructura del inconsciente. 
En cuanto a la primera articulación, hemos señalado que el hecho de que la materialidad de la ideología se despliegue a través de los aparatos ideológicos del Estado (AIE) -puesto que la ideología "existe siempre en el aparato que es su realización"- implica reconocer el funcionamiento de la ideología en su articulación con la reproducción de las relaciones de producción. En este marco, como hemos examinado, la ideología garantiza las prácticas requeridas por el sistema capitalista a través de la subjetivación/ sujeción de individuos como "sujetos" asegurando la reproducción de la ideología de las clases dominantes.

De esta manera, hemos expuesto el carácter necesario de la articulación entre la reproducción de las relaciones capitalistas de producción y la ideología a través de su función de interpelación. Y la necesariedad de la inmanencia de la ideología con sus prácticas, lo cual se vincula profundamente con el carácter transhistórico de la ideología que -al igual que el inconsciente- es eterno. Esta Ideología omnihistórica, general, se distingue de las ideologías particulares como la religión, la moral, la política; que son históricas, particulares y concretas.

En cuanto a la articulación de la ideología con la estructura del inconsciente, mostramos que, en Ideología y aparatos...la ideología es definida como la relación necesariamente imaginaria entre los individuos y sus condiciones de existencia. El carácter imaginario de la ideología -que refiere al objeto que es "representado" por estaimplica una lógica de reconocimiento/ desconocimiento, puesto que las prácticas que los individuos creen que realizan por su libre voluntad, en realidad, están determinadas con anterioridad; de acuerdo a las demandas de la estructura social. En este sentido, mostramos que es la práctica de la interpelación ideológica la que manifiesta que el sujeto es siempre ya sujeto a una determinada configuración ideológica. Develar este mecanismo, implicó realizar un rodeo por el análisis que Lacan realiza en el célebre "estadio del espejo", así como por el "materialismo de lo imaginario" de Spinoza.

Una vez realizado este rodeo, analizamos que la interpelación ideológica es presentada en el ensayo de 1970, como una escena de la vida cotidiana, en la que un sujeto es llamado por su nombre; dado que la práctica de la interpelación ideológica se articula con una de las evidencias más básicas que tenemos: la de ser sujetos (sobre la que Pêcheux desarrolla la evidencia del sentido). Examinamos que, la ideología en el marco de la teoria materialista de Althusser, tiene una estructura doblemente especular y una doble naturaleza ya que es tanto material como imaginaria. Esta estructura especular redoblada de la ideología queda asegurada según el esquema presentado por 
Althusser, por un cuádruple sistema por el cual los sujetos quedan sujetados, a excepción de los "malos sujetos". En esta línea, hemos analizado que, la necesariedad de que "los sujetos marchen solos", sin necesidad de hacer intervenir a los aparatos represivos, queda asegurada, porque la reproducción del sistema supone una lógica de reconocimiento/ desconocimiento y una dimensión de "lo imaginario".

Mostramos que, en el esquema presentado por Althusser en Ideología y aparatos...es la interpelación la que exige y ordena a los individuos para que se comporten como sujetos para ser incluidos entre los sujetos. Y estos se relacionan imaginariamente con su posición de sujeto, que se les presenta a ellos como autónomamente construida, cuando en realidad, como hemos visto, está siempre ya establecida. Lo que ha dado lugar a interpretaciones funcionalistas y reproductivistas vinculadas a la circularidad de la estructura ideológica, al funcionalismo de la ideología (de constituir sujetos que son siempre ya sujetos) y a la reproducción de las relaciones de producción.

Frente a las lecturas funcionalistas, argumentamos que estas se disipan al atender al estatuto central y transversal de la lucha de clases en la intervención althusseriana. En este sentido, examinamos la propuesta de Pêcheux de atender a la primacía de la lucha de clases que existe en la intervención materialista de Althusser; y, por lo tanto, a la posibilidad de transformar las relaciones de producción. Hemos evaluado en este sentido que, al reformular el estatuto de ideología, su naturaleza epistemológica, y sus alcances; Althusser también reformula la topografía marxista de la metáfora espacial del edificio compuesto por una base (infraestructura) sobre la que se levanta la superestructura. Esta metáfora, sostiene Althusser, tiene por objeto representar ante todo la determinación en última instancia por medio de la base económica bajo dos formas: 1) la de una autonomía relativa de la superestructura con respecto a la base;2) la de una reacción de la superestructura sobre la base.

En efecto, hemos examinado que, al reconocer la existencia material de la ideología -que se despliega a través de los aparatos ideológicos del Estado, cada uno de ellos siendo "la realización de una ideología "- Althusser amplía el análisis marxista que sólo reconocía la existencia del aparato de Estado que incluye no sólo el aparato especializado (el poder judicial, la policía, los tribunales, las prisiones) sino también el ejército. Y distingue así, entre ideología primaria (del Estado), y la ideología secundaria, como subproducto, en la práctica. Analizamos que, en este marco, si bien el Estado es “una 'máquina', un aparato de represión"; ninguna clase puede tener en sus manos el 
poder de Estado en forma duradera sin ejercer al mismo tiempo su hegemonía sobre y en los aparatos ideológicos del Estado, que son definidos como un sistema de instituciones, de organizaciones y de prácticas correspondientes definidas bajo los que se materializa todo o parte (en general, una combinación típica de ciertos elementos) de la Ideología de Estado. Estos aparatos, como señala Pêcheux, tienen un doble funcionamiento, además de tendencia a producir conflicto en lugar de orden.

Mostramos que esta potencialidad de desestabilizar las relaciones de producción, es constitutiva de los AIE ya que se encuentran regidos por la lucha de clases "que los atraviesa desde el principio". Por tanto, si bien, el componente conflictivo de los AIE es visibilizado con mayor predominancia en Sobre La reproducción, el texto del que es extractado Ideología y aparatos...en este último, la primacía de luchas se encuentra en la distinción entre "Ideología en general" de las "ideologías particulares", que se establece en el postcriptum.

Por otra parte, aunque en el mismo sentido, examinamos que, las perspectivas críticas de Zizek y de Butler en torno a la interpelación althusseriana tal como es presentada en el ensayo de 1970, reconocen en la falta de agencia de los sujetos sujetados, el síntoma de una falta de consideración de la dimensión inconsciente, en el caso del primero. Y el síntoma de la falta de comprensión -por parte de Althusser- del elemento pasional del mecanismo psíquico, en el caso de la segunda. Frente a estas críticas mostramos a) la posibilidad de transformar las relaciones de producción al enfatizar la transversalidad de la lucha de clases; y b) mostramos la articulación entre ideología e inconsciente que existe en la reformulación de la ideología propuesta por Althusser. Destacamos que esta articulación fundamental entre la ideología y el inconsciente es desarrollada por Althusser principalmente en Freud y Lacan, en Psicoanálisis y Ciencias Humanas, en las Cartas a D y en las Tres notas sobre la teoría de los discursos.

Mostramos que es en estas últimas, donde Althusser plantea una articulación diferencial entre la estructura del inconsciente y la estructura de la ideología ("el inconsciente es un mecanismo que funciona macizamente con "lo ideológico") desde una teoría materialista de los discursos. Hemos examinado que en estas notas de 1966 la función de la ideología es interpelar a los individuos como sujetos; transformando la función Träger impersonal en función- sujeto, por la articulación entre las instancias económico- social e ideológica. En este marco, el discurso ideológico produce una forma subjetiva que requiere a su Träger (soporte) individual presente en persona, por 
ello la posición "sujeto" solo compete al discurso ideológico. Y es una posición que se configura en cada caso singular, no anticipadamente. Con el examen de las Tres notas hemos mostramos que allí existe una articulación fundamental entre el discurso ideológico con el discurso del inconsciente que permite explicar la respuesta a un mandato y la identificación con el Significante amo, mediante la persuasión.

Al explorar la práctica de la interpelación ideológica, hemos examinado su genealogía, sus usos, derivas teóricas y límites. En este sentido, analizamos que la primera aparición del término se encuentra en las Tres notas sobre la teoría de los discursos, donde la elucidación del mecanismo de la interpelación ideológica se inscribe en una teoría materialista de los procesos discursivos, como un modo de conceptualizar la ideología. Sin embargo, tal como hemos enfatizado, este abordaje de la interpelación ideológica dentro de la problemática de la teoría de los discursos, es abandonada en Ideología y aparatos...donde Althusser se centra en las prácticas concretas que garantizan el funcionamiento de la ideología, y de los sujetos. Lo que constituye, tal como hemos postulado, un síntoma que leímos críticamente.

Por otra parte, y en continuidad con una lectura crítica, hemos argumentado que ni en las Tres notas..., ni en el ensayo Ideología y aparatos... aparece una preocupación por parte de Althusser en torno a los mecanismos específicos mediante los que se producen las subjetividades generizadas. Frente a este silencio teórico, propusimos realizar una lectura sintomática -aplicando al propio lapsus de Althusser el protocolo de lectura que él propone- así como propusimos leer críticamente su equívoco al final de las notas de 1966 en torno a la efectividad de los discursos.

Hemos señalado que en estas discontinuidades emerge para nosotros, la necesidad de indagar en torno a la compleja relación entre "ideología y género". Lo que propusimos abordar atendiendo a perspectivas feministas contemporáneas que insisten en la efectividad de los procesos ideológicos discursivos para la producción de las subjetividades generizadas.

En esta dirección, en la tercera parte, "Ideología y género, realizamos una lectura sintomática sobre el silencio de Althusser en torno a los procesos y mecanismos específicos mediante los que se producen las subjetividades con género; las que quedan sujetadas a lugares específicos de la estructura social, en cuanto a su pertenencia sexo/ género. Mostramos que al articular la estructura de la ideología y la de género es posible dar cuenta de los mecanismos específicos que constituyen a los "sujetos con género"; en 
los que, los discursos, entendidos desde su materialidad, juegan un rol central. Lo que pretendemos seguir desarrollando y profundizando en futuras investigaciones.

Entre los procedimientos desplegados para tal fin se encuentran:

. Examen el pensamiento althusseriano en tanto pensamiento situado en una coyuntura específica y en un contexto histórico-filosófico- concreto.

. Análisis de sus filiaciones, influencias, herencias y vinculaciones con otras corrientes de pensamiento, entre las que se destaca el vínculo con el psicoanálisis, cuya noción de inconsciente es central para comprender la dimensión imaginaria de la ideología. Así como el legado de una corriente filosófica materialista "subterránea", donde se destaca la figura de Spinoza.

Lo que nos permitió dar cuenta de que:

1) La intervención materialista de Althusser es fructífera para examinar y explicar problemas sociales actuales, dando lugar a cuestionamientos como: ¿bajo qué mecanismos los individuos se comportan de acuerdo con las demandas sociales? ¿Cómo se lleva a cabo la identificación con el Amo? ¿Cómo se mueven los cuerpos sujetados hacia determinados objetos de deseo? ¿Qué relación existe entre la ideología y la respuesta a los mandatos sociales?

2) la ideología desde una perspectiva materialista como la de Althusser logra no sólo eludir las dificultades que acechan al concepto de ideología si se la comprende como mera mistificación y representación falsa. Ya que, al caracterizar a la ideología como relación necesariamente imaginaria, Althusser nos ofrece una respuesta en torno a los procesos y mecanismos mediante los cuales se produce la constitución de sujetos. En este sentido, el mecanismo de la interpelación ideológica es una práctica con carácter necesario para garantizar la permanencia de la ideología dominante, cuya materialidad reside en constituir posiciones- sujetos que ocupen los lugares de la estructura social que requiere el sistema capitalista.

3) Al realizar una lectura sintomática sobre el propio pensamiento de Althusser, es posible dar lugar a una nueva problemática: la articulación entre ideología y género.

Los objetivos propuestos han sido desarrollados a lo largo de las tres partes que constituyen el presente trabajo. En la primera analizamos la lectura de Marx por Althusser y las bases centrales de la intervención materialista de Althusser. En la que, como hemos examinado, ocupa un lugar central la tesis del antihumanismo teórico de Marx, que se remonta al antihumanismo filosófico de Spinoza. 
La segunda parte, se centra en la tesis de la interpelación ideológica tal como es planteada en Ideología y aparatos... y algunas de las críticas que recibe este planteo; como las de Zizek y de Butler. Frente a las cuales hemos evaluado que el tratamiento que Althusser hace de la interpelación ideológica en las Tres notas... logra eludir (anticipadamente) muchas de las dificultades que se le presentan al planteo del ensayo de 1970. Sin embargo, hemos leído críticamente el abandono de una perspectiva materialista que existe en esta obra, así como propusimos una lectura sintomática sobre el silencio teórico de Althusser en torno a la cuestión de la producción de subjetividades generizadas.

En esta dirección, en la tercer y última parte de este trabajo titulada "Ideología y género" examinamos las tesis y los argumentos centrales desde los que leímos críticamente la ausencia de "la cuestión de género" en la propuesta de Althusser. Para ello, exploramos algunas propuestas feministas contemporáneas que han dado lugar a la compleja relación entre ideología y género, como la de Gale Rubín, Silvia Federici y Teresa de Lauretis.

En cuanto a la propuesta de Rubín, examinamos que esta analiza las condiciones bajo las que se producen los "sujetos con género" en el marco del sistema sexo/género, entendido como estructura heterosexual dominante. En este sentido mostramos que Rubín argumenta que los mecanismos de parentesco y el familiar son mecanismos de producción de sujetos generizados, que se reconocen como varones o mujeres, y que permiten la reproducción de las relaciones dicotómicas y jerárquicas dentro del sistema sexo/género.

Hemos evaluado que, si bien el esquema sexo/ género fue ampliamente discutido a partir de los '90 por implicar un reduccionismo, y por quedar supeditado a un esquema dicotómico y jerárquico sin lugar a las disidencias (Butler, 2007); el proyecto teórico/ político de Rubín -al analizar los vínculos entre las relaciones de poder sexo/género que subordinan a las mujeres con los procesos estructurales del desarrollo capitalista en términos de división sexual del trabajo-ha permitido dilucidar que el género entendido como diferencia sexual, oprime diferencialmente a mujeres y varones.

Por otra parte, atendiendo a los efectos que la división sexual del trabajo produjo en los sujetos- mujeres, mostramos que la propuesta de Silvia Federici permite destacar la centralidad de los discursos ideológicos, entendidos desde su materialidad puesto que ejercen una eficacia específica y concreta en la legitimación de las prácticas de explotación y de apropiación de los cuerpos, saberes y derechos de las subjetividades 
feminizadas. Con lo cual, el análisis de Federici demuestra que los discursos legitiman las prácticas de violencia contra las "mujeres"200; las que, homologadas a la naturaleza e identificadas con la corporalidad, fueron reclutadas a realizar el trabajo doméstico, no remunerado e invisibilizado.

En esta dirección, examinamos siguiendo la lectura de Federici que, en el contexto de instauración del capitalismo, el trabajo femenino se convirtió en un recurso natural disponible: las mujeres se constituyeron en bienes comunes y fueron obligadas a procrear y a realizar tareas domésticas que no categorizaban como trabajo asalariado. Evaluamos en este sentido, el acierto del planteo de Federici, y de las teóricas feministas de la reproducción, de mostrar que el ocultamiento de la explotación de las mujeres -y también de los sujetos coloniales- es lo que ha permitido al capitalismo acrecentar sus ganancias y acumular trabajo femenino "esclavo" a partir del marco legal de la división sexual del trabajo en público/privado. División en la que, como hemos analizado, el primero le queda asignado a los hombres, que trabajan por un salario; mientras que las mujeres quedan confinadas a realizar el trabajo doméstico y de los cuidados, gratuito, bajo el supuesto de una predisposición natural de las mujeres a realizar estas actividades. Examinamos en este sentido que, Federici advierte una ceguera de género de Marx que opera bajo la forma de un silencio teórico en su análisis de la acumulación capitalista.

Por otra parte, argumentamos que el análisis de Federici al analizar la imbricación entre capitalismo y patriarcado permite dilucidar la necesaria violencia patriarcal contra quienes suponen un peligro para el sistema capitalista. Hemos argumentado que esta "guerra contra las mujeres" toma una forma precisa en nuestra actualidad, puesto que los "voceros del proyecto histórico del capital" mediante discursos morales, naturalistas y esencialistas buscan legitimar prácticas de apropiación de los cuerpos y los saberes de las mujeres.

En esta dirección avanzamos en la tercera parte de este trabajo, en la que examinamos que el proceso ideológico- discursivo de rechazo a la "ideología de género" por parte de sectores neoconservadores y neoliberales que mediante una retórica antigénero restituyen un tratamiento idealista de la ideología y distorsionan el significado del "género" acuñado en la teoría feminista, para anularlo. Pero

${ }^{200}$ Entrecomillamos el concepto, puesto que como hemos argumentado en la III parte, se trata de una construcción social, que se contrapone a la concepción de mujer como bio-vaginal. 
sintomáticamente, revelan la politicidad del concepto, al colocarlo en el centro de la escena política.

En este sentido, hemos examinado que la acuñación del término pertenece al terreno de la teoría feminista. Nos hemos centrado en las reflexiones de Teresa de Lauretis, quien utiliza la expresión "ideología de género" para referir al marco en el que se constituyen diferencialmente los "sujetos con género", pero el género ya no es pensado como diferencia sexual -de hecho, tal como hemos explorado, Lauretis realiza fuertes críticas a esta concepción del género. Mostramos que Lauretis retoma explícitamente la tesis de la interpelación ideológica propuesta por Althusser para indagar en torno a los mecanismos de generización de las subjetividades en el marco de la ideología del género.

Por otra parte, hemos argumentado que el "rechazo a la "ideología de género", constituye un fenómeno ideológico discursivo que manifiesta el núcleo político del género en dos órdenes distintos:

a) a nivel teórico, cada vez que el concepto parece estabilizarse, y tornarse más neutral, y nulo.

b) a nivel práctico- político, los ataques al género, manifiestan que el estatuto de esta noción y la disputa por su significación, se encuentra en un campo de batalla. Puesto que el género, tiene potencialidad para desestabilizar las estructuras que, de opresión, con las que se articula.

Sobre los avatares del "género" en estos dos niveles hemos argumentado la necesidad de repolitizar el concepto mediante genealogías feministas políticas latinoamericanas que visibilicen el potencial político del género, atendiendo a nuestra pertenencia geopolítica. Así como de recomplejizarlo al escudriñarlo en perspectivas materialistas críticas, inclusivas e interseccionales, que visibilicen las múltiples y complejas articulaciones del género con otras matrices de opresión y de jerarquización.

Finalmente, después de todo lo expuesto, esperamos haber aportado elementos para intervenir filosóficamente en una problemática que para nosotros es urgente y es lo que proponemos seguir desarrollando en futuras investigaciones: una intervención materialista, feminista e interseccional de la articulación entre ideología y género. 


\section{BIBLIOGRAFÍA}

\section{Fuentes primarias de Althusser}

ALTHUSSER, Louis (1967a) "Sobre Feuerbach" en Escritos filosóficos y politicos, textos reunidos y presentados por François Matheron, t. 2, pp. 169- 244. París: STOCK/ IMEC. Título original: "Sur Feuerbach”, 1967. Traducción castellana: A. Arozamena. Disponible online: https://es.scribd.com/document/322251647/Sobre-Feuerbach-1967LouisAlthusser-pdf.

(1967b) "La querella del humanismo" en Écrits philosophiques et politiques, tomo II, Stock-IMEC, 1994. Textos reunidos y presentados por François Matheron, t. 2, pp. 433- 521. París: STOCK/ IMEC. Título original: "La querelle d 1'humanisme", 1967. Trad. castellana: A. Arozamena. Disponible online: https://es.scribd.com/doc/305206048/16175197-Althusser-Louis-La-Querella-Del-

Humanismo-1967-1.

(1968) La revolución teórica de Marx. Buenos Aires: Siglo

XXI editores. $2^{\circ}$ edición en español, corregida y aumentada: 1968. Trad. Martha Harnecker. Título original: Pour Marx, París, Maspero, colección “Théorie”, 1965.

(1970) Lenin y la filosofía. México: Ediciones Era. Traducción:

Felipe Sarabia. Publicación original en francés: Lénine et la philosophie, París, Máspero, colección "Théorie”, 1969.

(1974a) La filosofía como arma para la revolución. México:

Siglo XXI editores. $1^{\circ}$ edición: 1968.

(1974b) Para una crítica de la práctica teórica. Respuesta a John Lewis. México: Siglo XXI, traducción: Santiago Funes. Título original: Réponse a John Lewis, Librairie François Maspero, 1973.

(1975a) Elementos de Autocrítica. Barcelona: Editorial Laia. Publicación original: Elements d'autocritique. París: Librairie Hachette, colección “Analyse", 1974.

(1975b) Curso de filosofía para científicos: Buenos Aires: Laia.

Publicación original en francés: Philosophie et philosofie spontanée des savants. París, 
Maspero, colección “Théorie”, 1967.

(1988) Aparatos ideológicos del Estado. Buenos Aires:

Ediciones Nueva Visión. Publicación original: Ideologie et apparoils idéologiques d'État, París, La Pensee, 1970.

(1992) El porvenir es largo. Barcelona: Ediciones Destino, colección Áncora y Delfín. Traducción: Marta Pessadorrona. Título original: L'avenir dure longtemps suivi de Les fats, París: Stock/ IMEC, 1992.

(1996) Escritos sobre psicoanálisis. Freud y Lacan. México:

Siglo XXI editores. Traducción: Eliane Cazenave- Tapie. Título original: Écrits sur la psychanalyse.Freud et Lacan. París: Stock/ IMEC, 1993.

(2002) "La corriente subterránea del materialismo del encuentro" en Para un materialismo aleatorio. Madrid: Arena. Traducción de Luis Alegre Zahonero Y Guadalupe González Diéguez Publicación original: "Le courant souterrain du matérialisme de la rencontre”, París: Stock/ IMEC, 1982.

(2003) Marx dentro de sus límites. Madrid: AKAL.

(2005) Filosofía y marxismo. Entrevista con Fernanda

Navarro. México: Siglo XXI editores. $1^{\circ}$ edición: 1988.

(2007a) Política e historia: De Maquiavelo a Marx. Cursos

en la Escuela Normal Superior 1955-1972. Buenos Aires: Katz. Publicación original: Politique et historie de Machiavel a Marx. Cours a l'École Normale Superieure 19551972, París : SeuiL, 2006.

(2007b) "La única tradición materialista" en Youkali,

Revista de las artes y el pensamiento, n 4, 2007; pp. 132-154. Publicación original en francés: 1985.

(2008) "Defensa de tesis de Amiens" en La soledad de

Maquiavelo. Barcelona: Akal. Título original: Solicitude de Machiavel. Press Universitaires de France, 1998.

(2014) Psicoanálisis y ciencias humanas. Dos conferencias. 
(1963-1964). Buenos Aires: Nueva Visión. Publicación original: Psychanalyse et Sciences humaines (Deux conferences), París : Le Livre de Poche, 1996.

(2015a) Iniciación a la filosofía para los no filósofos. Buenos Aires: Paidós. Traducción: Alcira Bixio. Título original: Initiation à la philosophie pour les non- philosophes.París: PUF, 1975.

(2015b) Sobre la reproducción [1970] Madrid: Akal.

Traducción: Alfredo Brorons Muñoz. Publicación original: Sur la reproduction, París: PUF, 1995.

(2017) Ser Marxista en Filosofía [1975] Madrid: AKAL. Título original: Etre marxiste en philosophie.

Y BADIOU, ALAIN (1983) Materialismo histórico y materialismo dialéctico. Buenos Aires: Ediciones Pasado y Presente. $1^{\text {o }}$ edición: 1969.

Y BALIBAR, Étienne (2004) Para leer el capital. México: Siglo XXI Editores, $1^{\circ}$ edición en español: 1967. Traducción de Martha Harnecker. Publicación original en francés: Lire le Capital, París, Máspero, colección "Théorie", 1965.

y GARCÍA DEL CAMPO, Juan Pedro (2014b) "Sobre la génesis" en Revista DécalagesVol. 1: Iss. 2.

y KARCZMARCZYK, P., tr. (2015b) “¿Qué es la colección Théorie?" en Demarcaciones (3), 74-77. En Memoria Académica. Disponible en: http://www.memoria.fahce.unlp.edu.ar/art revistas/pr.7452/pr.7452.pdf.

\section{Fuentes primarias de Marx}

MARX, Karl (1970) Contribución al a crítica de la economía política. Buenos Aires: Estudio. (1984) Manuscritos económicos- filosóficos de 1844. Economía política y Filosofía. Buenos Aires: Cartago (2002) Introducción a los Elementos Fundamentales para la crítica de la 
economía política (borrador) 1857-1858, vol. 1. México: Siglo XXI editores. Título original: Gründisse der Kritik der politischen Okonomie, Berlín, 1953. Traducción Pedro Scaron, $1^{\circ}$ edición 1971.

(2015) El Capital: El proceso de producción del capital. Libro I, Vol 1 y vol. 3. Buenos Aires: Siglo XXI editores. Traducción Pedro Scaron. Título original: Das Kapital. Kritik der politischen Ökonomie.

(2012) Cuaderno Spinoza. Traducción, estudio Preliminar y notas de Nicolás González Varela. Madrid: Ediciones de Intervención Cultural/ Montesinos.

Y ENGELS Friedrich (2005) La ideología alemana. Buenos Aires:

Santiago Rueda editores.

\section{Fuentes primarias de Spinoza}

SPINOZA, Baruch (2002) Ética demostrada según el orden geométrico. Barcelona: Editorial Trotta. Edición y traducción: Atilano Domínguez.

(1986) Tratado político. Madrid: Editorial Alianza. Trad.: Atiliano

Domínguez.

\section{Fuentes primarias de Teresa de Lauretis}

De LAURETIS, Teresa (1992) Alicia, ya no. Feminismo, Semiótica, Cine. Madrid: Ediciones Cátedra. Título original: Alice doesn't. $1^{\circ}$ edición: 1984.

(1993) "Sujetos excéntricos: la teoría feminista y la conciencia histórica" publicado originalmente en De mujer a género, teoría, interpretación y prácticas feministas en las ciencias sociales; María C. Cangiamo y Lindsay Dubois (comps.) Buenos Aires: Centro editor de América Latina, 1993, pp. 73- 163.

(1996) "La tecnología del género" en Revista Mora nro. 2, año 1996. Tomado de Technologies of Gender. Essays on Theory, Film and Fiction, London: Macmillan Press, 1989, pp. 1- 30.

(2000) Diferencias. Etapas de un camino a través del feminismo.

Madrid: Horas y horas editorial. 
(2014) "Cuando las lesbianas no éramos mujeres" traducción gaby herczeg, Bocavularia ediciones. Trabajo originalmente escrito y presentado en el Coloquio en torno a la obra política, teórica y literaria de Monique Wittig; París, 16 y 17 de junio de 2001.

\section{Fuentes primarias de otros autores}

AAVV (1997) Lacan con los filósofos. Madrid: Siglo XXI.

ADAMS, Parveen (1992) "Hacer de madre" en Debate feminista núm. 6, septiembre, México, publicación original, 1983.

AGUILAR RIVERO, Mariflor (1984) Teoría de la ideología. Ciudad de México: Universidad Nacional Autónoma de México.

(2008) “Interpelación y subjetividad" en Revista de Filsofía Onlehner de la UNED, Madrid, julio de 2008.

ANGENOT, Marc (2010). El discurso social. Los límites de lo pensable y lo decible. Buenos Aires: Siglo XXI. Traducción Hilda García.

ARRUZZA, Cinzia (2010) "Las peligrosas relaciones entre género y clase" en Las sin parte. Matrimonios y divorcios entre feminismo y marxismo, pp. 93- 115. Madrid: Izquierda Anticapitalista.

ASSITER, Alison (1990) Althusser and feminism. Londres: Pluto Press.

BACHELARD, Gastón (2000) La formación del espíritu científico. Contribución a un psicoanálisis del conocimiento objetivo. Buenos Aires: Siglo XXI editores. Traducción castellana: José Babini, 23º edición. $1^{\circ}$ edición 1948.

BALIBAR, Etiénne (1976) Cinco ensayos de materialismo histórico. Barcelona: Editorial Laia. $1^{\circ}$ edición en francés: $1974.1^{\circ}$ edición en español: 1976.

(2004) Escritos por Althusser. Buenos Aires: Nueva Visión.

(2005) Violencias, identidades y civilidad. Para una cultura politica global. Madrid: Gedisa. 
(2016) "Nota sobre la teoría del discurso" (noviembre de 1966, concluido en enero de 1967) en Décalages, Vol., 2 (2016), Iss. 1, Art, 20.

Y WALLERSTEIN, I. (1998) Raza, Nación y clase. Madrid:

Iepala.

BARRET, Michel (2008); "Ideología, política y hegemonía: de Gramsci a Laclau y Mouffe”, en Ideología. Un mapa de la cuestión, Buenos Aires: FCE.

BARTH, Hans (1951) Verdad e ideología, México: Fondo de Cultura Económica, $1^{\circ}$ edición en alemán 1945.

BARTHES, Roland (1990) La aventura semiológica. Barcelona: Tusquets.

BOLTANSKI, Luc y CHIAPELLO, Éve (2002) El nuevo espíritu del capitalismo, Madrid, Akal, Cuestiones de Antagonismo.

BUTLER, Judith (2001) Mecanismos psíquicos del poder, Madrid: editorial Cátedra. Publicación original: The psychic life of power, Stanford University Press, 1997.

(2007) El género en disputa. El feminismo y la subversión de la identidad. Barcelona: Espasa libros. Título original: Gender Trouble. Feminism and the Subversion of Identity. Publicado en inglés en 1990 por Routledge, New York.

(2008) Cuerpos que importan. Sobre los límites materiales y discursivos del "sexo". Trad. Alcira Bixio. Buenos Aires: Paidós. Publicación original: Bodies that matter, London: Routledge, 1993.

BRAIDOTTI, Rosi (2000) Sujetos nómades. Corporización y diferencia sexual en la teoría feminista contemporánea. Buenos Aires: Paidós. Título original: Nomadic Subjects. Embodiment and Sexual Difference in Contemporary Feminist Theory. Nueva York. Columbia University Press, 1994.

(2004) Feminismo, diferencia sexual y subjetividad nómade.

Barcelona: Gedisa editorial.

BRAUNSTEIN, Jean-François (2002) "Bachelard, Canguilhem, Foucault. El 'estilo francés' en epistemología", en WAGNER, Pierre (Dir.), Les philosophes et la science. 
París: Gallimard.

CALLINICOS, Alex (1978) El Marxismo de Althusser. Buenos Aires: Premia editoraLa red de Jonás.

CALVINO, Ítalo (1988) Las ciudades invisibles. Buenos Aires: Minotauro. $1^{\circ}$ edición en italiano: 1972.

CAMPAGNOLI, Mabel (2011) "Genealogías del género. Ilustración y libertades". Revista de pensamiento e historia de las ideas (2), 109-147.

CANGUILHEM, George (1996) Nuevas reflexiones concernientes a lo normal y lo patológico, México: Siglo XXI editores.

CAPDEVILLA, Néstor (2007) El concepto de ideología. Buenos Aires: Nueva visión.

CAVARERO, Adriana (1995) "Para una teoría de la diferencia sexual" en Debate feminista, vol. 12, octubre 1995, pp. 152- 184.

CIRIZA, Alejandra (1994) "Feminismo y política en dos encrucijadas históricas. La modernidad madura" en Revista de Filosofia Universidad de Costa Rica, XXXII (/7). 41- 0,19

(2007) "Apuntes para una crítica feminista de los atolladeros del género" en Dossier "Sobre la noción de género. Usos, debates y perspectivas" en Estudios de Filosofía práctica e historia de las ideas, Año 8, N 9, Mendoza, diciembre de 2007.

CLEAVER, Harry (1985) Una lectura política de "El Capital”. México: FCE. Trad. Eduardo L. Suárez. $1^{\circ}$ edición: 1979.

COLAIZZI, Giulia (1990) Feminismo y teoría del discurso. Madrid: Ediciones Cátedra. CONTÉ, Claude (1997) "Lacan y la función del simbolismo" en Lacan con los filósofos. Madrid: Siglo XXI editores.

CURIEL, Ochy (2013) La nación heterosexual. Análisis del discurso jurídico y el régimen heterosexual desde la antropología de la dominación, Bogotá, Brecha lésbica y en la frontera. 
CHÁNETON, July (2007) Género, poder y discursos sociales. Buenos Aires: Eudeba.

CRENSHAW, Kimberlé (1991) "Mapping the Margins: Intersectionality, Identity Politics, and Violence Against Women of Color" en Stanford Law Review 43, (6), pp. 1241-99.

DALLA, Mariarosa y JAMES, Selma (1972) El poder de la mujer y la subversión de la comunidad, México: Siglo XXI.

DAVIS, Ángela (2004) Mujeres, raza y clase. Madrid: Akal. Trad. Ana Maria Varelos. Título original: Women, race and class. London: The Women's press, 1981.

(2012) "I Used to Be Your Sweet Mama: Ideología, sexualidad y domesticidad" en Feminismos negros. Una antología. Madrid: Traficantes de sueños.

De GAINZA, Mariana (2013) "Zizek y Althusser. Vida o Muerte de la lectura sintomática" en Décalages: Vol. 1: Iss. 1.

(2018) "El problema de las distinciones en Spinoza. Una subversión crítica de Descartes" en Éndoxa. Series filosóficas, nro. 41, 2018, pp. 55-73, UNED, Madrid.

DELPHY, Christine (1985) "Por un feminismo materialista. El enemigo principal y otros textos". En: Cuadernos inacabados 2.3, Barcelona, La Sal ediciones de les dones.

DERRIDA, Jacques (1976) Posiciones. Valencia: Pretextos.

(1995) Espectros de Marx. El estado de la deuda, el trabajo del duelo y la nueva internacional. Madrid: Trotta. Trad. J. M. Alarcón, y C. M. Peretti.

DESCARTES, René (1963) Las pasiones del alma. Buenos Aires: Aguilar ediciones. Título original: les passions de l'âme, publicado por primera vez en 1649.

DE ÍPOLA, Emilio (2007) Althusser, el infinito adiós. Buenos Aires: Siglo XXI.

DUSSEL, Enrique (2008) “Anti-meditaciones cartesianas: sobre el origen del antidiscurso filosófico de la modernidad" en Tabula Rasa. 9: 153-197.

EAGLETON, Terry (1997) Ideología. Una introducción. Barcelona: Paidós. (2012) Por qué Marx tenía razón. Barcelona: Atalaya. 
ECHAVARRÍA CANTO, Laura (2017) “La noción de 'malos sujetos' en la obra de Mariflor Aguilar" en Universidades, núm. 71, enero-marzo, 2017, pp. 43-50 Unión de Universidades de América Latina y el Caribe Distrito Federal, Organismo Internacional.

ELLIOT, Gregory (2006) Althusser: the detour of theory. Boston: Brill.

ESQUISABEL, Oscar (2016) "Leibniz y la hermenéutica: perspectivismo y fusión de horizontes “en Dissertatio - Volume Suplementar, Outubro - 2016.

FEDERICI, Silvia (2010) Mujeres, cuerpo y acumulación originaria. Buenos Aires: Tinta Limón. Publicación original: Caliban and the Witch: Women, the Body and Primitive Accumulation. Nueva York: Autonomedia, 2004.

(2018) El patriarcado del salario. Buenos Aires: Tinta Limón.

FEMENÍAS, María Luisa (2012) "Feminismo y Multiculturalismo: Voces y cuerpos "marcados" en la era de la globalización" en Revista Europea de Derechos Fundamentales, nro. 19/1er Semestre 2012; pp. 75 - 93.

FERNÁNDEZ LIRIA, Pedro (2002) Regreso al "campo de batalla”. En: L. Althusser. Para un materialismo aleatorio (pp.73-125). Madrid: Arena.

FOURTUONIS, Giorgos. (2014) "El materialismo Tardío de Althusser y el Corte Epistemológico", Décalages: Vol.1: Iss. 1. Traducción: Aurelio Sainz Pezonaga.

FREUD, Sigmund (1979) "La interpretación de los sueños", Obras Completas. Buenos Aires: Amorrortu.

(2003) "Algunas consecuencias psíquicas de la diferencia anatómica entre los sexos" en Obras Completas, Buenos Aires: Amorrortu; pp. 257-276, $1^{\circ}$ edición: 1925.

FISCHBACH, Franck (2012) Marx. Releer El Capital. Madrid: Ediciones Akal.

FOUCAULT, Michael (1980) El orden del discurso. Barcelona: Tusquets, $1^{\circ}$ edición, 1970.

(1995) "El sujeto y el poder" en Terán, Oscar (Comp.), Michel Foucault. Discurso, poder y subjetividad. Buenos Aires: el cielo por asalto ediciones. 
(2002) Historia de la sexualidad 1: La voluntad de saber.

Buenos Aires: Siglo XXI editores.

(2010) Las palabras y las cosas. Una arqueología de las ciencias humanas. Buenos Aires: Siglo XXI editores. $1^{\text {a }}$ edición: 1966, Gallimard.

GILlOT, Pascale (2010) Althusser y el psicoanálisis, Buenos Aires: Nueva visión. Traducción castellana de Heber Cardoso.

GONZÁLEZ ORTUÑO, Gabriela (2016) “Transmodernidad y feminismo en dos pensadoras caribeñas: Ochy Curiel y Yuderkys Espinosa" en Gandarilla, J (comps) Crítica en el margen. Hacia una cartografía conceptual para rediscutir la modernidad. Ciudad de México: Akal; pp. 521- 536.

GOSHGARIAN, G. M y ÉWANJÉ- EPÉE (2016) "Filosofía y revolución. Althusser sin teoricismo: entrevista con G. M. Goshgarian” en Décalages: vol. 2; Iss. 1.

GRAMSCI, Antonio (1971) El materialismo histórico y la filosofía de Benedetto Croce. Buenos Aires: ediciones Nueva Visión.

GROSFOGUEL, Ramón (2013) "Racismo/sexismo epistémico, universidades occidentalizadas y los cuatro genocidios/ epistemicidios del largo siglo XVI" en Tabula Rasa, 19: 31-58, julio-diciembre 2013.

GUATTARI, Félix y ROLNIK, Suely (2013) Micropolítica. Cartografías del deseo. Buenos Aires: Tinta limón.

GUILLAUMIN, Colette (2005) "Práctica del poder e idea de Naturaleza" en y Curiel, Ochy y Falquet, Jules (2005) El patriarcado al desnudo. Tres feministas materialistas: Colette Guillaumin - Paola Tabet - Nicole Claude Mathieu, Buenos Aires, Brecha lésbica ediciones. Publicado inicialmente en Questions Féministes, $\mathrm{n}^{\circ} 2$ y 3, febrero y mayo de 1978.

HANECKER, Marta (1996) "Marxismo y Humanismo” en Papers 50; pp.121-132.

HARAWAY, Donna (1991) Ciencia, cyborgs y mujeres. La reinvención de la naturaleza. Madrid: Cátedra.

(1993) "Saberes situados: el problema de la ciencia en el 
feminismo y el privilegio de una perspectiva parcial", en Cecilia Cangiano y Lindsay Dubois, De mujer a género, Buenos Aires: CEAL.

(1999) "La promesa de los monstruos: una política regeneradora para otros inapropiados/ bles" en Política y sociedad, 30 (1999). Madrid; pp. 121- 163.

HARDING, Sandra (1996) Ciencia y feminismo. Madrid: Morata. Título original: The Science Question in Feminism, New York: Cornell University Press, 1986.

HARVEY, David (2014) Guía de El Capital. Libro primero. Madrid: Ediciones Akal.

HARTMANN, Heidi (1979) "The Unhappy Marriage of Marxism and Feminism: Towards a More Progressive Union", en: Capital \& Class, No. 3, pp. 1-33. ed. cast. «Un matrimonio mal avenido: hacia una unión más progresiva entre marxismo y feminismo», Papers de la Fundación núm. 88.

hooks, bell (2007) El feminismo es para todo el mundo. Buenos Aires: Tinta limón. Publicación original: Feminism is for everybody: passionate politics, Nueva York, South and Press, 2000.

ICHIDA, Yoshihico (2007) “Althusser y la cuestión del sujeto", Revista Youkali, n 4, diciembre de 2007; pp. 73-78.

IRIGARAY, Luce (1982) Ese sexo que no es uno. Madrid: Saltés. Trad. Sylvia E. Tubert. Publicación original en francés: Ce sexe qui n'en est pas un. París. Les Éditions de Minuit, 1977.

KARCZMARCZYK, Pedro (2014) "De las formas históricas de existencia de la individualidad a la forma sujeto del discurso: Marx, Althusser, Pêcheux," en Décalages: Vol. 1: Iss. 4.Available at: http://scholar.oxy.edu/decalages/vol1/iss4/25.

(2016a) “De Althusser a Althusser, pasando por Pêcheux y Herbert” en Daniel Busdygan, Victoria Sánchez Paz y Federico López (eds.) Conocimiento, arte y valoración: perspectivas filosóficas actuales, Bernal, UNQui, 2016, ISBN: 978-987-558-383-2, pp. 98-121.

(2016b) Presentación a "La internacional de los buenos sentimientos" de Louis Althusser. Demarcaciones (4), 272-291. En Memoria Académica: http://www.memoria.fahce.unlp.edu.ar/art_revistas/pr.7327/pr.7327.pdf. 
KARSZ, Saúl (1970) Lectura de Althusser, Buenos Aires: Edit. Galerna

LACAN, Jacques (1977) Los cuatro conceptos fundamentales del inconsciente. Seminario 11. Buenos Aires: Paidós.

(2012) "El estadio del espejo como formador de la función del yo (je) tal como se nos revela en la experiencia psicoanalítica" en Escritos. Tomo I. Buenos Aires: Siglo XXI Editores. Trad.: Tomás Segovia. $1^{\circ}$ edición francesa: 1966.

LACLAU, Ernesto (2000) Nuevas reflexiones sobre la revolución de nuestro tiempo. Buenos Aires: Nueva Visión.

y MOUFFE, Chantal (2010) Hegemonía y estrategia socialista.

Buenos Aires: FCE.

LAPLANCHE, Jean et al (2004) Diccionario de psicoanálisis. Buenos Aires. Paidós. Título original: Vocabulaire de la Psychanalise, $1^{\circ}$ edición: 1967, Press Universitaires de France, París.

LARRAÍN, Jorge (2007) El concepto de ideología, vol.1. Santiago de Chile: LOM Ediciones.

LINHART, Robert (2008) De cadenas y de Hombres, México: Siglo XXI. Trad.: Stella Mastrángelo, publicación original: 1979.

LECOURT, Dominique (1974) Ensayo sobre la posición de Lenin en filosofía. Buenos Aires: Siglo XXI editores.

(1984) El orden y los juegos. Buenos Aires: De La Flor.

(1987) Para una crítica de la epistemología, Buenos Aires:

Siglo XXI editores, $1^{\circ}$ edición en español: 1973.

LEFORT, Claude (1990) La invención democrática, Buenos Aires: Nueva Visión.

LEMKE, Theodor et al. (2006) Marx y Foucault. Buenos Aires: Nueva Visión.

LENIN, Vladimir (1975) Materialismo y Empiriocriticismo. Pekín: Ediciones en Lenguas extranjeras, $1^{\circ}$ edición: Moscú: 1948. 
LENK, Kurt (2007) "Introducción” a Lenk, K. (Comp.) El concepto de ideología, Buenos Aires: Amorrortu.

LOBO, Marisa (2016) Ideologia de gênero na Educação. Curitiba: Edição do autor.

LORDON, Frédéric (2015) Capitalismo, deseo y servidumbre. Marx y Spinoza. Buenos Aires: Tinta Limón.

(2017) Los afectos de la politica. Zaragoza: Universidad de Zaragoza. Edición original en francés: 2016.

LUGONES, María (2012) "Subjetividad esclava, colonialidad de género, marginalidad y opresiones múltiples”. En Pensando los feminismos en Bolivia. La Paz: Conexión Fondo de Emancipaciones.

MACHADO, María das Dores Campos (2018) "El discurso cristiano sobre la "ideología de género". Revista Estudios Feministas. vol.26, n.2, e47463. pub 11-Jun-2018.

MACHEREY, Pierre (2014a) "Lengua, discurso, ideología, sujeto, sentido: de Thomas Herbert à Michel Pêcheux", Décalages. An Althusser Studies Journal, Vol. 1, Iss. 4.

(2014b) Hegel o Spinoza. Buenos Aires: Tinta Limón.

y GARCÍA DEL CAMPO, J. P (2014) "Sobre la génesis" en Décalages: Vol. $\quad$ : $\quad$ Iss. $2 . \quad$ Disponible online: http://scholar.oxy.edu/decalages/vol1/iss2/12.

MAININI, Gabriela (2015) "Louis Althusser: el sujeto entre comillas" en Astrolabio. Revista internacional de filosofía, Año 2015 Núm. 17. ISSN 1699-7549. pp. 1-10.

MARÍ, Enrique Eduardo (1974) Neopositivismo y e ideología, Buenos Aires: Edit. Universidad de Buenos Aires.

MARÍN, Juan Carlos (1987) La silla en la cabeza. Michel Foucault en una polémica acerca del saber y el poder. Buenos Aires: Editorial Nueva América.

MARTINEZ MARTINEZ, Francisco José (2010) “Autoconstitución y libertad Ontología y política en Espinosa III" en Eikasia. Revista de Filosofía. Año V, 30 (enero 2010). http://www.revistadefilosofia.org. 
MASOTTA, Oscar (2015) Lecturas de psicoanálisis. Freud. Lacan. Buenos Aires: Paidós.

MEILLASOUX, Claude (1977) Mujeres, graneros y capitales, México: Siglo XXI.

MERCIER, Tomás (2019) "Diferencia sexual, diferencia ideológica: lecturas a contratiempo (Derrida lector de Marx y Althusser en la década de 1970 y más allá) en Revista Demarcaciones, Dossier, abril 2019. Traducción de Ramiro Parodi.

MILLET, Kate (1995) Política sexual. Madrid: Ediciones Cátedra. Traducción Ana María Bravo García. Título original: Politics sexual, 1969.

MILNER, James (2003) El periplo estructural. Figuras y paradigma. Buenos Aires: Amorrortu Editores. $1^{\circ}$ edición: Le périple structural. Figures et paradigme. Editions du Seuil, París, 2002.

MITCHELL, Juliet (1975) Psychoanalysis and Feminism, Harmondsworth, Penguin.

(1984) Women, the longest revolution. New York: Pantheon Books.

MONTAG, Warren (2005) Cuerpos, masa, poder. Spinoza y sus contemporáneos. Madrid: Tierra de nadie Editores.

(2009) "El alma es la prisión del cuerpo". Althusser y Foucault: 1970-1975 en Youkali, revista crítica de las artes y el pensamiento. Vol. 8, pp. 155169. Trad.: Aurelio Pezonaga.

(2013) “El Althusser Tardío: ¿Materialismo del Encuentro o Filosofía de la Nada? Décalages: Vol. 1: Iss. 1. Traducción: Aurelio Sainz Pezonaga. Disponible en: http://scholar.oxy.edu/decalages/vol1/iss1/2/.

(2015) "Discurso y decreto: Spinoza, Althusser y Pêcheux" en Revista Representaciones, Vol. XI, No 1 - Julio 2015, pp. 11-4.

(2018) Entrevista a Warren Montag por Juan del Mazo: "Para Althusser, la filosofía debe sacudir las cosas" en Semanario de La izquierda diario del 09/09/ 2018. Disponible online: http://www.laizquierdadiario.com/Para-Althusser-lafilosofia-debe-sacudir-las-cosas.

MORFINO, Vittorio (2014) El materialismo de Althusser. Santiago de Chile: Polinodia. 
NAVARRO, Fernanda (2007) "La actualidad de las últimas reflexiones sobre la política de L. Althusser" en Youkali, revista crítica de las artes y el pensamiento, vol.3 pp.3-13. NEGRI, Antonio (2019) Marx y Foucault. Ensayos 1. Buenos Aires: Editorial Cactus. Colección Occursus.

OGILVIE, Bertrand (2010) Lacan, la formación del concepto de sujeto (1932-1949), Buenos Aires: Ediciones Nueva Visión.

PAVÓN CUELLAR, David (2014) Elementos políticos del marxismo lacaniano. México: Paradiso editores.

PARRA, Fabiana (2016) “Género, Violencia Sexual y Dictadura. En torno al intento de aniquilamiento de las mujeres como sujetos durante la última dictadura cívico-militar argentina" en Actas de las IV Jornadas del Centro Interdisciplinario de Investigaciones en Género, Facultad de Humanidades y Ciencias de la Educación, La Plata.

(2018) “Ideología, discursos morales y violencia de género. La mirada del "otro" sobre nuestros cuerpos". Question, 1(57), e019. DOI: https://doi.org/10.24215/16696581e019.

(2019) “La ideología en la propuesta filosófico-contemporánea de Louis Althusser" (Tesis de posgrado). Presentada en Universidad Nacional de Quilmes. para optar al grado de Magíster en Filosofía. Disponible en Disponible en RIDAA-UNQ Repositorio. Institucional Digital de Acceso Abierto de la Universidad Nacional de Quilmes https://ridaa.unq.edu.ar/handle/20.500.11807/2017

PASCAL (1943) Pensamientos. Buenos Aires: Espasa Calpe. Publicado originalmente en 1669.

PÊCHEUX, Michel (2008) “El mecanismo del reconocimiento ideológico”. En S. Zizek (Comp.), Ideología. Un mapa de la cuestión (pp.157-167). Buenos Aires: Fondo de Cultura Económica.

(2014)"¡Osar pensar y osar rebelarse! Ideologías, marxismo, lucha de clases" en Décalages An Althusser Studies Journal. Occidental Collège: Vol. 1: Iss. 4. Available at: http://scholar.oxy.edu/decalages/vol1/iss4/14. Texto traducido por Silvia Hernández. 
(2016) Las verdades evidentes. Buenos Aires: Centro Cultural de la Cooperación. Traducción: Mara Glozman. Título original: Les Vérités de La Palice, 1975.

PÉREZ OROZCO, Amaia (2014) Subversión feminista de la economía. Aportes para el debate sobre el conflicto capital- vida. Madrid: Traficantes de sueños.

POULANTZAS, Nicolás (1979) Estado, poder y socialismo. Madrid: Siglo XXI.

QUIJANO, Aníbal (2000) "Colonialidad del poder, eurocentrismo y América Latina". En: E. Lander (comp.), Colonialidad del saber, eurocentrismo y ciencias sociales, Buenos Aires, CLACSO- UNESCO.

RADFORD, Hill y RUSSELL, Diana (2006) Femicidio. La política del asesinato de las mujeres. México: UNAM.

RANCIERE, Jacques (1970) "Sobre la teoría de la ideología" en Lectura de Althusser. Buenos Aires: Galerna.

(2014) La lección de Althusser, Madrid: LOM ediciones. $1^{\text {a }}$ edición: 1974.

RICH, Adrienne (1999) "La heterosexualidad obligatoria y la existencia lesbiana" en Navarro Marysa y Stimpson, Catherine (comps.) Sexualidad, género y roles sexuales. Buenos Aires: FCE.

ROIES, Albert (1974) Lectura de Marx por Althusser, Barcelona: editorial Laia.

ROMÉ, Natalia (2014) La posición materialista: el pensamiento de Louis Althusser entre la práctica teórica y la práctica política, La Plata: EDULP.

RUBÍN, Gayle (1986) "El tráfico de mujeres: notas sobre la economía política del sexo" en Nueva antropología, Vol. VIII, nro. 30, México: Universidad Nacional Autónoma de México, pp. 95- 145.Publicación original: "The Traffic in Women: Notes on the 'Political Economy' of Sex", en Rayna R, Reiter(ed.), Towards an anthropology of Women, Nueva York, 1975, pp. 167-168.

SALLEH, Ariel (1997) Ecofeminism as Politics: Nature, Marx and the Postmodern. Londres: Zed Books. 
SAUSSURE, Ferdinand (1996) Curso de lingüística general. Buenos Aires: Editorial Losada. Título original francés: Course de linguistique genérale, primera publicación: 1945.

SCALA, Jorge (2010) La ideología de género o el género como herramienta del poder. Rosario: Editorial Logos.

SCIORTINO, Silvana (2014) “Antropología y feminismos en América latina: hacia una práctica descolonial" en Teoría feminista y antropología: claves analíticas. Madrid: editorial Centro de Estudios Ramón Areces.

SCOTT, Joan (1993) "El género: una categoría útil para el análisis histórico" en Cangiano, María Cecilia y Dubois, Lindsay (comps.) De mujer a género. Teoría y práctica feminista en las ciencias sociales, Buenos Aires: CEDAL.

SEGATO, Rita (2013) Las estructuras elementales de la violencia. Buenos Aires: Prometeo. (2016) La guerra contra las mujeres, Madrid: Tinta Limón.

SIBERTIN-BLANC, Guillaume (2015) Prefacio a la Iniciación a la filosofía para los no filósofos. Buenos Aires: Paidós. Traducción: Alcira Bixio.

STAVRAKAKIS, Yannis (2007) Lacan y lo politico. Buenos Aires: Prometeo libros. Publicación original: Lacan and the Political, London: Verso, 1999.

STENGERS, Isabelle y PIGNARD, Phillip (2018) La brujería capitalista. Buenos Aires: Hekht libros. $1^{\circ}$ edición: 2005, Editions La Decouverte.

STARCENBAUM, Marcelo (2017) "Mauricio Malamud: filósofo comunista" en Malamud, M. (2017). Escritos (1969- 1987). Santiago de Chile: Doble Ciencia editorial. STOLCKE, Verena (2000) “¿Es el sexo para el género lo que la raza para la etnicidad...la naturaleza para la sociedad?" en Política y cultura 14, Universidad Autónoma Metropolitana- Xochimilco, Distrito federal, México; pp. 25- 60.

TARCUS, Horacio (2015) Antología de Karl Marx, Buenos Aires: Siglo XXI editores.

THERBORN, Göran (1980) Ciencia, clase y sociedad. Madrid, Siglo XXI. 
TIJOUX, María Emilia y PALOMINOS MANDIOLA, Simón (2015) “Aproximaciones teóricas para el estudio de procesos de racialización y sexualización en los fenómenos migratorios de Chile" en Polis, 42, pp. 247- 275.

TOSEL, André (2015) "De la teoría estructural a la coyuntura aleatoria" en Demarcaciones abril-mayo-junio 2015, pp. 31-46. Traducción: Pedro Karczmarczyk. (2016) "De Spinoza a Gramsci. Entrevista con André Tosel” en Demarcaciones 6, 2018. Entrevista realizada por G. Rebucini el 30 de mayo de 2016. Période, mayo de 2016. Trad. F. Pereyra Rozas. Revisión técnica: P. Karczmarczyk.

TRÍAS, Eugenio (1970) Teoría de la ideología. Barcelona: Península.

VACAREZZA, Nayla (2010) "Aportes de Spinoza para reflexionar acerca de la vida corporal del género, las mujeres y el feminismo" en A parte rei. Revista de filosofía 71, setiembre de 2010 .

VERÓN, Eliseo (1987) La semiosis social. Buenos Aires: Gedisa.

(2004) "Diccionario de lugares no comunes". En: Fragmentos de un tejido. Buenos Aires: Gedisa.

VILLORO, Juan. (1979) "El concepto de ideología en Marx y Engels" en Ideología y ciencias sociales. Ciudad de México: UNAM.

VIVEROS VIGOYA, Mara (2016) "La interseccionalidad: una aproximación situada a la dominación". Universidad Nacional de Colombia, Bogotá, disponible en https://www.sciencedirect.com/science/article/pii/S0188947816300603.

VOLOSHINÓV, Valentín (2009) El marxismo y la filosofía del lenguaje, Madrid: Alianza Editorial.

WALLERSTEIN, Immanuel (2014) El capitalismo histórico, trad. de P. López Mañez, Buenos Aires: Siglo XXI.

WILLIAMS, Raymond (2009) Marxismo y Literatura. Buenos Aires: Las Cuarenta.

WIITIG, Monique (2006) El pensamiento heterosexual y otros ensayos. Barcelona: Editorial Egales. Traducción de Javier Sáez y Paco Vidarte. Publicación original: The 
Straight Mind and other essays. Boston: Beacon Press, 1992.

ZIZEK, Slavoj (comp.) (2008) Ideología. Un mapa de la cuestión. Ciudad de México: Fondo de Cultura Económica. (2009) El sublime objeto de la ideología. Buenos Aires: Siglo

XXI.

\section{Documentos}

Subsecretaria de equidad y calidad educativa. Programa Nacional de Educación Sexual Integral (2012) "Educación Sexual Integral para la Educación Secundaria II. Contenidos y propuestas para el aula en Serie Cuadernos ESI. Ministerio de Educación de la Nación Argentina.

Consejo Federal de Educación. (2008) "Lineamientos curriculares para la Educación Sexual Integral” del Programa Nacional de Educación Sexual Integral Ley Nro. 26.150, Ministerio de Educación de la Nación Argentina.

Consejo Federal de Educación (2018) Anexo Resolución del CFE $N^{\circ}$ 340/18 del Programa Nacional de Educación Sexual Integral Ley nro. 26. 150, Ministerio de Educación de la Nación Argentina.

\section{Fuentes secundarias}

BALIBAR, Étienne (2013) Ciudadano sujeto. Buenos Aires: Prometeo. trad. de César Marchesino.

BALTAS, Arístides (1993). "Filosofía y la filosofía espontánea de los científicos y otros ensayos por Louis Althusser," en Filosofía de la ciencia, 60 (4): 647-658.

BOER, Roland (2007) "Crítica del cielo: sobre el marxismo y la teología” en Serie de libros de materialismo histórico, Nueva York: Brill Academic.

BOURGEOIS, Bernard (1997). "Althusser et Hegel" en P. Raymond (Ed.), Althusser Philosophe, París : Presses Universitaires de France, 87-104.

BUTLER, Judith (2009) "La vulnerabilidad lingüística". En: Lenguaje, poder $e$ identidad. Ed. Síntesis, 2009. 
(2006) "Violencia, duelo, política". En: Vida precaria. El poder del duelo y la violencia. Paidós, Barcelona.

CASALE, Rolando, et al. (2017) Judith Butler fuera de sí. Espectros, diálogos y referentes polémicos. Rosario: Prohistoria.

CIRIZA, Alejandra (2004) "Notas sobre los límites de la importación teórica en la teoría feminista y los estudios de género. A propósito de Judith Butler”, en El Rodaballo, Revista de política y cultura, Buenos Aires, Año X, N15, invierno de 2004, pp. 57-61.

HARDING, Sandra (1987) Feminism and methodology: Social Sciences Issues, Bloomington, Indiana University Press, p. 1- 14.

KARCZMARCZYK, Pedro (2012) "Discurso y subjetividad: Michel Pêcheux, hacia una teoría de las garantías ideológicas" en VII Jornadas de Sociología de la UNLP, diciembre de 2012, La Plata, Buenos Aires.

LACLAU, Ernesto y ZAC, Lilian (2002). "Cuidado con el vacío: el sujeto de la política" en Buenfil, R. N. (Coord.), Configuraciones discursivas en el campo educativo, Ciudad de México: Plaza y Valdés-SADE.

MACEY, David (1994) "Pensar con conceptos prestados: Althusser y Lacan", en GREGORY Elliott (ed.), Althusser: un lector crítico, Oxford: Blackwell, 142-158.

MACHEREY, Pierre (2002) "Althusser et le jeune Marx", Actuel-Marx,31 : 159-175.

MALDIDIER, Denise y ROBIN, Regine (1977) «Du spectacle au meurtre de l' evénement : reportages, commentaires et éditauriaux a propos de Charlety » (mai 1968) en Pratiques, nro. 14, 1977.

MALABOU, Catherine (2016). "Où va le réalisme ? Althusser / Darwin " Lignes, 51: 351.

MARTÍNEZ MARTÍNEZ, Francisco José (1988) Materialismo, idea de totalidad y método deductivo en Espinosa. Madrid: UNED.

MATHERON, François (1998)"La recurrencia del vacío en Louis Althusser", Repensando el marxismo, 10 (3): 22-27.

(2004) "Louis Althusser, o, la pureza impura del concepto," 
Graduate Faculty Philosophy Journal, 25 (1): 137-15.

MONTAG, Warren (1998) "Nominalismo de Althusser: Estructura y Singularidad (1962-66)," Repensando el marxismo, 10 (3): 64-73.

(2014) "Entre la interpelación y la inmunización: Althusser, Balibar, Espósito” en Revista Demarcaciones, vol. 1, año 1, abril del 2014.

(2015b) “Althusser y el problema de la escatología" en Revista Demarcaciones, nro.3, abril del 2015.

MOREAU, Pierre-François (1997) "Althusser et Spinoza", en P. Raymond (Ed), Althusser Philosophe, París: Presses Universitaires de France, 75-86.

MORFINO, Vitorrio (2005) "Un léxico althusseriano", traducido por Jason Smith, Borderlands e-journal, 4 (2).

MOULIER BOUTANG, Yann (1992) Louis Althusser: Une Biographie (Tomé I: La formación del mito, 1918-956), París: Bernard Grasset.

PATTON, Paul (1978) "La epistemología de Althusser: Los límites de la teoría de la práctica teórica", Radical Philosophy, 19: 8-18.

PFEIFER, Geoff (2015) El Nuevo Materialismo: Althusser, Badiou, Zizek, Londres: Routledge.

O'HAGAN, Timothy (1982)"Althusser: Cómo ser un marxista en Filosofía", en GHR Parkinson (ed.), Marx y Marxismos, Cambridge: Cambridge University Press, 243-264.

RANCIÈRE, Jacques (2011) Lección de Althusser, Emiliano Battista (trad.), Continuum, 2011

RESCH, Robert Paul (1992) Althusser y la renovación de la teoría social marxista, Berkeley: University of California Press.

ROUDINESCO, Elisabeth (2008) Filosofia en tiempos turbulentos: Canguilhem, Sartre, Foucault, Althusser, Deleuze, Derrida, Nueva York: Columbia University Press.

SCOTT, Joan (1988) Gender and the Politics of History, Nueva York: Columbia 
University Press.

SÈVE, Lucien (1997)"Althusser et la dialectique", en P. Raymond (Ed.), Althusser Philosophe, París : Presses Universitaire de France, 105-136.

SMITH, Steven (1984) Lectura Althusser: un Ensayo sobre el marxismo estructural, Ithaca, NY: Cornell University Press.

SOTIRIS, Pedro (2014) "Repensar la estructura y la coyuntura en Althusser", Historical Materialism, 22 (3/4): 5-51.

SPRINKER, Michael (1995) "Los legados de Althusser", Yale French Studies, 88: 201225.

STARCENBAUM, Marcelo (2011) "El marxismo incómodo: Althusser en la experiencia de Pasado y Presente" en Revista www.izquierdas.cl, 11, diciembre 2011, pp.35-53.

SUCHTIG, Wal (2004) "Pensamiento tardío de Althusser sobre el materialismo", Materialismo histórico, 12 (1): 3-70.

THOMAS, Peter (2002) "Estrategias filosóficas: Althusser y Spinoza," Historical Materialism, 10 (3): 71-113.

VATTER, Miguel (2004) "Maquiavelo después de Marx: la auto superación del marxismo en el último Althusser," Teoría y evento 7 (4).

WILLIAMS, Caroline (2001) Filosofía francesa contemporánea: la modernidad y la persistencia del sujeto, Londres, Athlon. 